\title{
Geologic Map of the Simcoe Mountains Volcanic Field, Main Central Segment, Yakama Nation, Washington
}

By Wes Hildreth and Judy Fierstein

Pamphlet to accompany

Scientific Investigations Map 3315

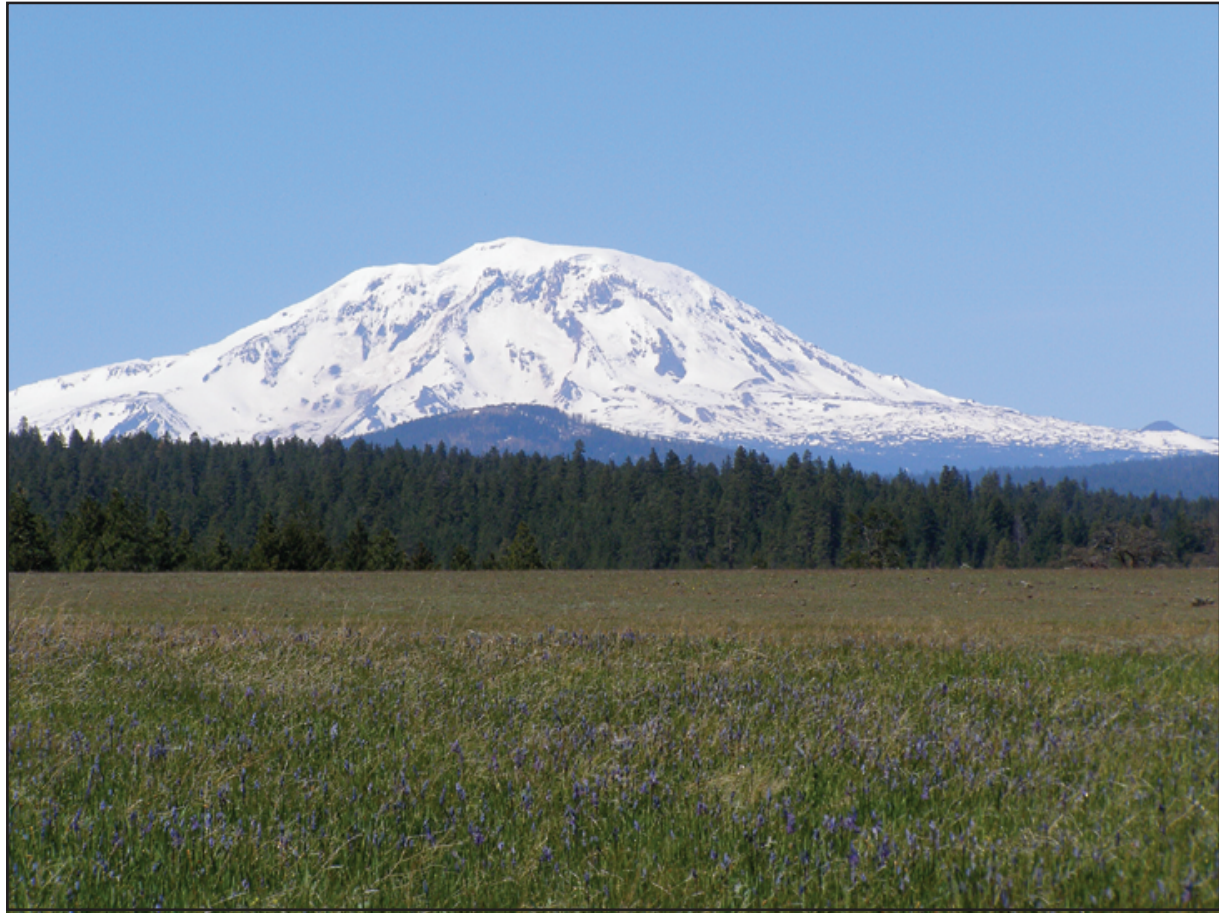

Photograph showing Mount Adams andesitic stratovolcano and Signal Peak mafic shield volcano viewed westward from near Mill Creek Guard Station. Low-relief rocky meadows and modest forested ridges marked by scattered cinder cones and shields are common landforms in Simcoe Mountains volcanic field. Mount Adams (elevation: 12,276 ft; 3,742 m) is centered $50 \mathrm{~km}$ west and $2.8 \mathrm{~km}$ higher than foreground meadow (elevation: 2,950 ft.; $900 \mathrm{~m}$ ); its eruptions began $\sim 520 \mathrm{ka}$, its upper cone was built in late Pleistocene, and several eruptions have taken place in the Holocene. Signal Peak (elevation: 5,100 ft; 1,555 m), $20 \mathrm{~km}$ west of camera, is one of largest and highest eruptive centers in Simcoe Mountains volcanic field; short-lived shield, built around 3.7 $\mathrm{Ma}$, is seven times older than Mount Adams. 



\section{Contents}

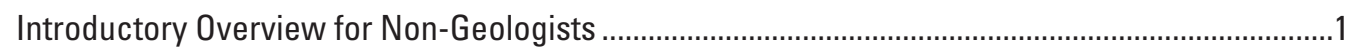

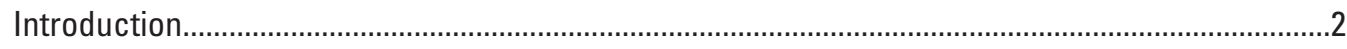

Physiography, Environment, Boundary Surveys, and Access ................................................

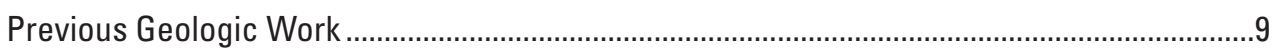

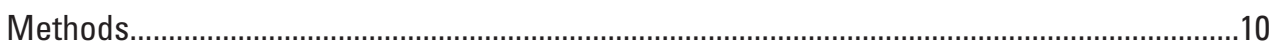

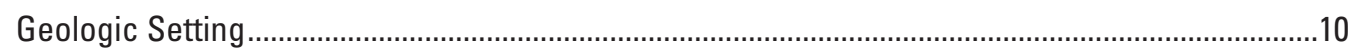

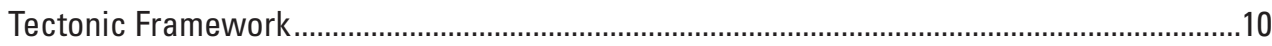

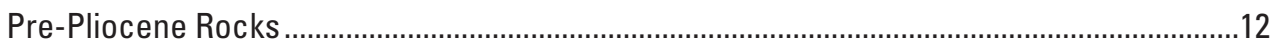

Mount Adams Volcanic Field ........................................................................................12

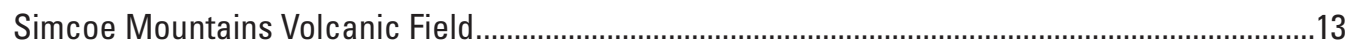

Central Segment.

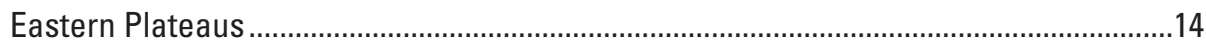

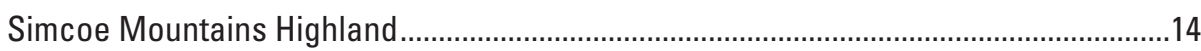

Central Swath of High Vent Density...........................................................................16

Swath of Lesser Vent Density ........................................................................................16

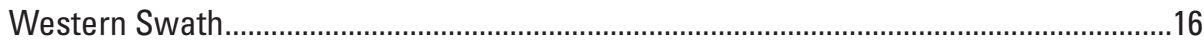

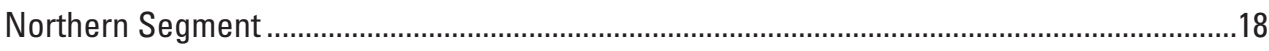

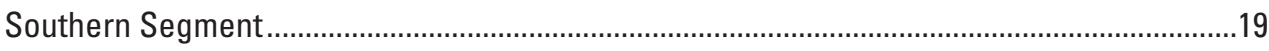

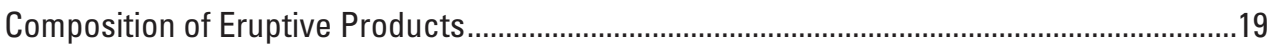

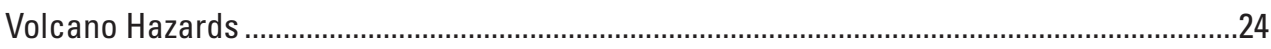

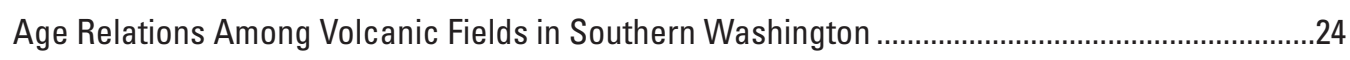

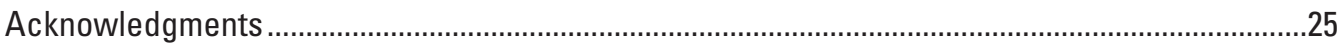

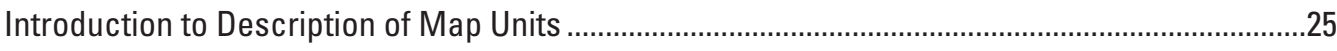

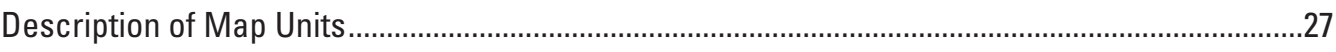

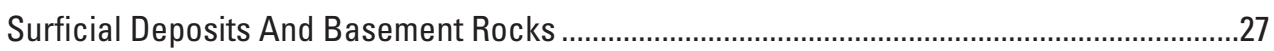

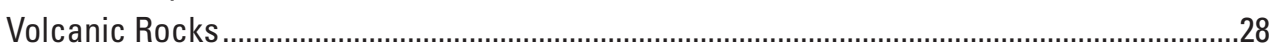

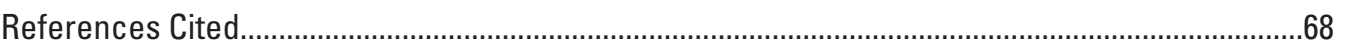

\section{Figures}

1. Map showing regional location of intraplate Simcoe Mountains volcanic field in south-central Washington.

$2 A$. Map showing regional setting of map area and Yakama Nation in south-central Washington.

2B. Regional physiography as digital elevation model, illustrating transition from rugged Cascade Range to Yakima Fold Belt......

3. Map showing drainage of Simcoe Mountains volcanic field and vicinity, including locations of geographic names mentioned in text and in Description of Map Units.

4. Map showing simplified tectonic map of Pacific Northwest, highlighting Simcoe Mountains volcanic field draping southwest part of Yakima Foldbelt, east of Cascade Arc axis. .........................................................................................................11

5. Vent locations for central segment of Simcoe Mountains volcanic field. ........................15

6. $\mathrm{Fe} 0 * / \mathrm{MgO}$ versus weight percent $\mathrm{SiO}_{2}$ for $\sim 1,250$ samples from central segment of Simcoe Mountains volcanic field.

7. $\mathrm{K}_{2} \mathrm{O}$ versus $\mathrm{SiO}_{2^{\prime}}$, both in weight percent, for $\sim 1,300$ samples from central segment of Simcoe Mountains volcanic field. 
8. Total alkalies versus silica (TAS) diagram of LeBas and others (1986), showing conventional chemical pigeon-holing of volcanic rock names for $\sim 1,300$ samples from central segment of Simcoe Mountains volcanic field.

9. Ba and $\mathrm{Zr}$ versus $\mathrm{Nb}$, all in ppm, for $\sim 1,250$ samples from central segment of Simcoe Mountains volcanic field.

\section{Table}

1. ${ }^{40} \mathrm{Ar} /{ }^{39} \mathrm{Ar}$ ages for basalt samples from Simcoe Mountains volcanic field

\section{Appendixes}

Appendix A. Chemical data for Simcoe Mountains volcanic field, main central segment.. web only

Appendix B. Whole-rock potassium-argon ages for units within or overlapping Simcoe Mountains volcanic field, main central segment. 
Are they assigned, or can the countries pick their colors?

- What suits the character or the native waters best.

Topography displays no favorites; North's as near as West.

More delicate than the historians' are the map-makers' colors.

Elizabeth Bishop from The Map (1935)

\section{Introductory Overview for Non-Geologists}

Mountainous parts of the Yakama Nation lands in southcentral Washington are mostly covered by basaltic lava flows and cinder cones that make up the Simcoe Mountains volcanic field (figs. 1-5). The accompanying geologic map of the central part of the volcanic field has been produced by the U.S. Geological Survey (USGS) on behalf of the Water Resources Program of the Yakama Nation. The volcanic terrain stretches continuously from Mount Adams eastward as far as Satus Pass and Mill Creek Guard Station. Most of the many hills and buttes are volcanic cones where cinders and spatter piled up around erupting vents while lava flows spread downslope. All of these small volcanoes are now extinct, and, even during their active lifetimes, most of them erupted for no more than a few years. On the Yakama Nation lands, the only large long-lived volcano capable of erupting again in the future is Mount Adams, on the western boundary.

The geologic map presented here extends, east-west, from Satus Creek to the Klickitat River and, north-south, from Signal Peak to Indian Rock. In various colors, the map shows the areas covered by about 223 different eruptive units, mostly lava flows and cinder cones, while stars mark vents where many of them erupted. Shown in plain gray, the basement beneath the Simcoe Mountains volcanic field is the Columbia River Basalt Group, regional "flood basalts" of enormous volume and extent that erupted far to the east and long before the Simcoe volcanics.

Although the number of past eruptions is large, few were great explosions that fed towering eruption plumes or spread ash over huge areas downwind. Most were localized basaltic lava fountains (like some in Hawaii) where showers of molten fragments reached heights of a few hundred feet. Most of them also poured out tongues of lava that were channelled along stream valleys for a few miles downstream or, occasionally, as far as 10 miles. Because the basalt so common here is one of the most fluid kinds of lava, it tends to flow farther and faster than most other types of lava before it cools and solidifies.

Lava compositions other than various types of basalt are uncommon here. Andesite is abundant on and around Mount Adams but is very rare east of the Klickitat River. The only important nonbasaltic composition in the map area is rhyolite, which crops out in several patches around the central highland of the volcanic field, mainly in the upper canyons of Satus and Kusshi Creeks and Wilson Charley canyon. Because the rhyolites were some of the earliest lavas erupted here, they are widely concealed by later basalts and therefore crop out only in local windows eroded by canyons that cut through the overlying basalts.
When still molten, rhyolite lava is much stiffer than basalt. Instead of flowing freely, it creeps along like warm road tar and seldom advances far from its vent. Additionally, as a result of its stiffness, rhyolite can be much more explosive than basalt. Deep below ground, all lava contains dissolved gases (water, sulfur, and carbon dioxide), which try to bubble away as the lava rises buoyantly to the surface from its higher-pressure subsurface confinement. If the depressurizing ascent is rapid, the stiffness of rhyolite retards escape of the gas, which instead makes the lava froth up into an explosive foam of ash and pumice when it emerges into the atmosphere. Rhyolite lavas of the Simcoe Mountains were certainly accompanied by such explosive eruptions of ash and pumice, but most deposits of such loose material have since been eroded away. A few remnants of the ash deposits survive near Tenie Creek and along Highway 97 north of Satus Pass, and stream-reworked rhyolite pumice is present in the alluvium downstream along Satus Creek.

Its lack of fluidity also helps hot rhyolitic lava oozing out at the surface to chill quickly into solid glass rather than to solidify slowly into the finely crystalline, stony lava typical of more fluid, higher-temperature basalts. Dense, pure rhyolite glass is known as obsidian, which is normally black where freshest, gray when hydrated, or reddish when oxidized. Fragments of obsidian currently eroding out of rhyolite outcrops are found (1) along the north side of Tenie Creek, (2) along the road just southwest of Castle Rock, (3) on both walls of upper Satus Creek canyon, (4) in the headwaters of Kusshi Creek and Wilson Charley canyon, (5) on slopes east of Tadpole Lake, and (6) just south of the map area, on the south slopes of Indian Rock and in the nearby headwaters of Devils Canyon and West Prong Little Klickitat River.

Many volcanic vents in the Simcoe Mountains area are simple cones of cinders (also called scoria), which are fragments of bubbly lava that solidified during airborne trajectories. In some of the cones, the ejected fragments had cooled before they hit the ground and therefore piled up as layers of loose cinders. In other cones, however, fragments were still partly molten spatter when they hit the ground, allowing them to stick together to form blobby sheets as rough and tough as a lava flow. Loose cinders are easy to quarry for direct use as road metal or yard gravel, but welded spatter (like any solid rock) has first to be crushed. Long ridges of cinders and spatter form where chains of cones coalesce or, alternatively, erupt from linear fissures instead of point-source vents. Most cinders start out black and many remain so, but if the hot fragments are exposed to rainfall or steam during or soon after eruption, they often oxidize brick red, especially near vents where hot gas emission continues long after eruptions end.

Cinders are widely used to provide traction on back roads and logging tracks. For unpaved high-speed roads, however, crushed lava is preferred because cinders are readily pulverized by traffic into fine ash that yields clouds of dust. On Yakama Nation lands and throughout southern Washington, most road metal is prepared by crushing the denser tougher lava flows so widely exposed. Most quarries are in thick lava flows of the Columbia River Basalt Group, but some are in Simcoe Mountains lava flows. In both cases, the rocks selected for 
quarries tend to be free of bubbles (vesicles) and millimetersized feldspar crystals (common in many other units), both of which would promote disintegration of the crushed gravel into dust under the stress of road traffic. Chunky gravel crushed from dense crystal-free lava flows is far more durable.

Several east-west ridges (Ahtanum, Toppenish, and Peavine Ridges and the Horse Heaven Hills) dominate the topography of much of the Yakama Nation terrain. Each main ridge is an anticline, which (like a rug wrinkle) is an upward fold in the regional basement rocks that lie beneath the local lava flows of the Simcoe Mountains volcanic field. These basement rocks are themselves lava flows but they did not erupt here. Instead, they are flood lavas of enormous extent that erupted from fissures near the Idaho-Washington-Oregon borders and poured westward, blanketing the landscape to depths of thousands of feet, banking against the ancestral Cascade Range, and following the ancestral Columbia River valley to the Pacific Ocean. These great lava flows belong to the Columbia River Basalt Group, and they include hundreds of thick lava flows, most of which are about four times as old as the oldest locally erupted lava flows of the Simcoe Mountains volcanic field. The folds were raised by region-wide tectonicplate motions that caused north-south compression, resulting in narrow anticlinal ridges that extend tens of miles east-west. Most of the folding took place before the Simcoe Mountains lava flows began erupting here about four million years ago, but slight uplift of a few Simcoe units on slopes of anticlines shows that a little of the folding continued more recently.

Lava flows of the Simcoe Mountains volcanic field are generally covered by several feet of silty soil (loess), much of which was blown here by winds from barren areas of the Cascade Range during the ice ages (Pleistocene). Beneath such soils, however, tops of most flows are rubbly and porous, and interior parts typically contain abundant fractures. These properties make the Simcoe Mountains lava flows highly permeable, promoting infiltration of rainfall and snowmelt and favoring rapid lateral transport of groundwater. By contrast, the underlying lava flows of the much older Columbia River Basalt Group are less permeable, because flows are thicker and denser and many of their cracks have been sealed by long-term precipitation of secondary minerals. Recharge of groundwater aquifers for the agricultural lowlands of the Toppenish Creek and Satus Creek drainage systems and for the Goldendale area, therefore, takes place as water percolates outward from the forested highlands, where annual precipitation is much greater, through permeable Simcoe Mountains lava flows.

Natural springs are numerous around the Simcoe Mountains highlands. The volcanic field consists of hundreds of lava flows, and rubbly zones between flows are far more permeable than interiors and therefore provide favored pathways for groundwater movement. Where creeks have cut channels down into piles of stacked lava flows, the rubbly zones are exposed and commonly become sites of groundwater discharge as seeps and springs. Water quality is generally good in the highland volcanic field, because the area has no year-round habitation and no fertilized agriculture. The primary land uses are timber harvesting, dispersed grazing, and cultural and recreational activities.
Glaciers covered much of the Cascade Range of Washington during the ice ages, and some small glaciers still exist nearby at the Goat Rocks and Mount Adams. Because the Simcoe Mountains are lower in elevation (maximum 5,823 ft at Indian Rock) and in the rainshadow of the Cascades, however, no glaciers are known to have ever accumulated here. We think, nonetheless, that local ice slopes did accumulate on two northeast-facing cliffs, above Lakebeds and the headwaters of Satus Creek.

Yakama tradition recounts conflict and competition among ancient spiritual entities that represented Mount Adams, Mount Hood, and Mount St. Helens, the three large snow-capped stratovolcanoes often called "the Guardians of the Columbia." Consistent with the tradition, argon geochronology suggests that Mount Adams and Mount Hood are similar in age and that Mount St. Helens is younger, roughly half as old. We discuss the age relations later in this report, but it can be generalized here that the Simcoe Mountains volcanic field is much older than all three of the Guardians. Intermittent eruptions of lava flows and cinder cones in the Simcoe Mountains were scattered over a very long time span, but they came to an end at about the same time that Mount Adams and Mount Hood first became active.

The 223 volcanic units delineated on the geologic map were defined in the field by systematic traverses on foot over the span of ten summers (2000-2009). Each one is an "eruptive unit" from a single vent or fissure. Some are simple lava flows or cones, but many are stacks of flows or radial aprons of several similar flows erupted from the same vent. The best exposures of sequences of different lavas are on canyon walls, our repeated descents and ascents of which were arduous but geologically informative. In the lab, samples of each unit were chemically analyzed, in part to confirm the integrity and uniqueness of each set of flows we mapped. Microscope slides of each unit were examined to clarify rock textures, crystal contents, and types of minerals present. In the Description of Map Units, we summarize for each unit the areal, physical, textural, chemical, and mineralogical features by which they are distinguished. The Correlation of Map Units (sheet 3) shows graphically the relative ages of the 223 units. The more detailed Introduction that follows describes the area mapped and the geologic methods used in investigating it.

\section{Introduction}

The Simcoe Mountains volcanic field of south-central Washington (fig. 1), geologically long neglected, has remained one of the least known young volcanic areas in the United States. Our mapping, on behalf of the Yakama Nation, has now remedied this. Draped over about 1,660 $\mathrm{km}^{2}$ of the Yakima Foldbelt, the eruptive products are predominantly alkalic intraplate basalts, along with a continuum of fractionated intermediate alkalic products, subordinate subalkaline mafic lavas, and several rhyolites. They erupted from $\sim 205$ recognized vents, mostly scoria cones and small shields that range in age from $\sim 4 \mathrm{Ma}$ to $0.6 \mathrm{Ma}$. Contrary to longstanding misimpression, 


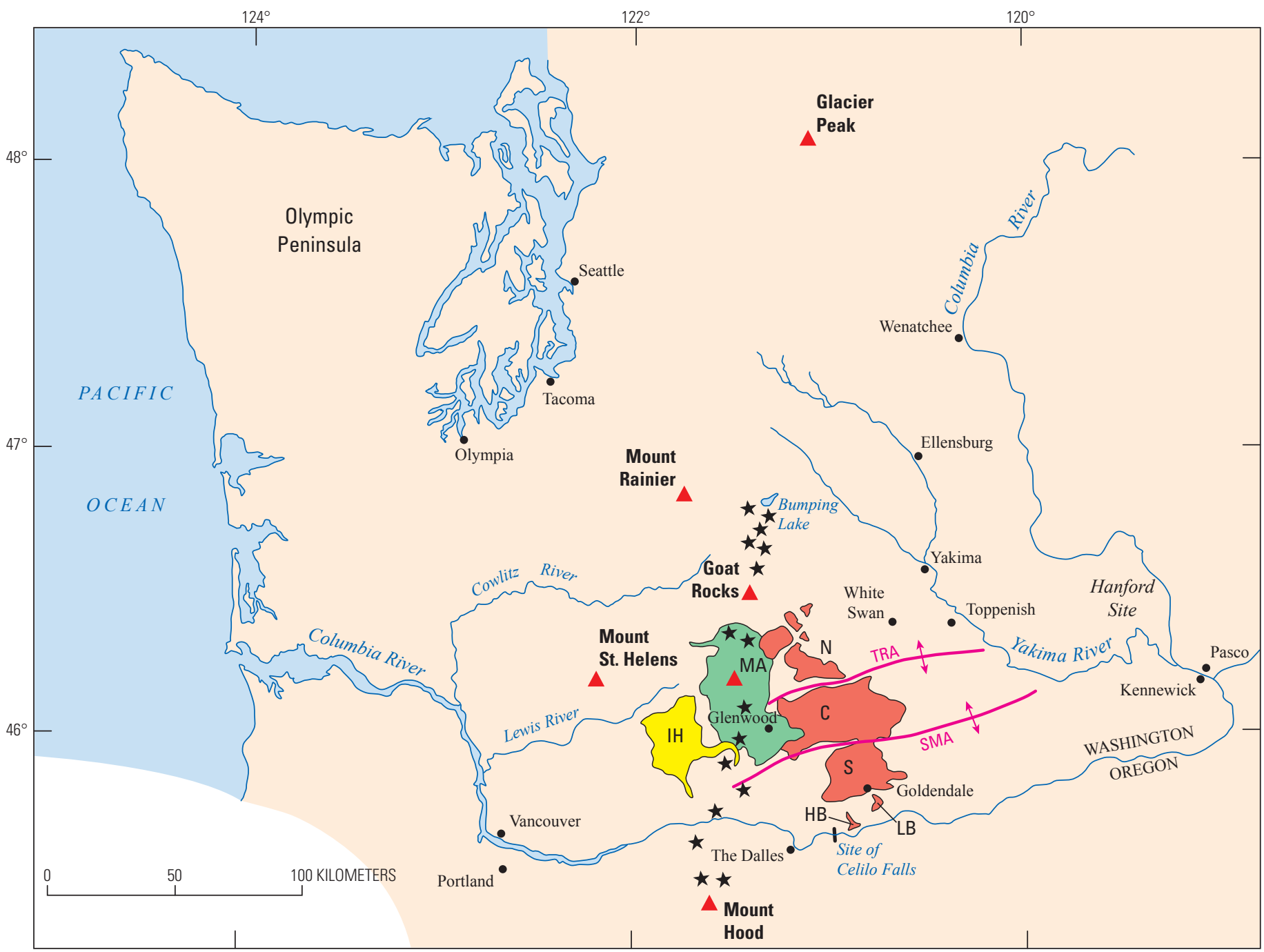

Figure 1. Map showing regional location of intraplate Simcoe Mountains volcanic field (in red) in south-central Washington. Field is divided into three segments by crests of two anticlines (red lines) of the Yakima Foldbelt-N, northern; C, central; S, southern. Directly west are Mount Adams (MA) and Indian Heaven (IH) volcanic fields. Quaternary axis of Cascade Arc extends northward from Mount Hood to Bumping Lake and includes 150 separate volcanoes, predominantly basaltic (see fig. 8 of Hildreth, 2007); along arc axis, selected cones and shields are indicated by stars and stratocone complexes by red triangles. Southernmost outliers of Simcoe Mountains volcanic field are Haystack Butte (HB) and Lorena Butte (LB). Anticline abbreviations: SMA, Simcoe Mountains Anticline; TRA, Toppenish Ridge Anticline.

only a fraction of the field is Pliocene; much of it is early Quaternary. Another widespread misimpression has been that the Simcoe Mountains volcanic field is part of the Cascade Arc, which lies adjacent on its west. It is, instead, a distributed field of intraplate basalts, many of which have ocean-islandbasalt-like geochemical signatures, carry mantle xenoliths, and fractionate to alkalic intermediates rather than arc andesites.

The volcanic field is divisible geographically into three parts (fig. 1) by a parallel pair of east-west-trending basement anticlines. The anticlines, elements of the Yakima Foldbelt, consist of Miocene flood basalts of the Columbia River Basalt Group, which almost everywhere forms the basement of the Simcoe Mountains volcanic field. The southern part of the volcanic field is a $460-\mathrm{km}^{2}$ area that extends from the Simcoe Mountains Anticline nearly to the Columbia River and is largely on private lands near the Klickitat County seat at Goldendale.
The $250-\mathrm{km}^{2}$ northern part, only $7-17 \mathrm{~km}$ wide, extends 25 $\mathrm{km}$ northwestward from the Toppenish Ridge-Peavine Ridge Anticline to the rugged headwaters of the Klickitat River, where it adjoins the Goat Rocks arc-volcanic cluster. The $950-\mathrm{km}^{2}$ central part, which extends $60 \mathrm{~km}$ east-west and $25 \mathrm{~km}$ northsouth, drapes and lies between the anticlines, contains twothirds of the vents, and is the subject of the present geologic map. The central and northern parts of the volcanic field are in the Closed Area of the Yakama Nation (fig. 2) and are open only to enrolled members and approved permittees.

The Closed Area makes up two-thirds of the $5,660-\mathrm{km}^{2}$ Yakama Indian Reservation (fig. 2). Nearly all of the Closed Area is now held in trust for the Yakama Nation, whereas open areas (Glenwood valley and the eastern third of the reservation, outside the volcanic field) are checkerboards of parcels held variously in trust or in fee by Indian or non-Indian owners. 


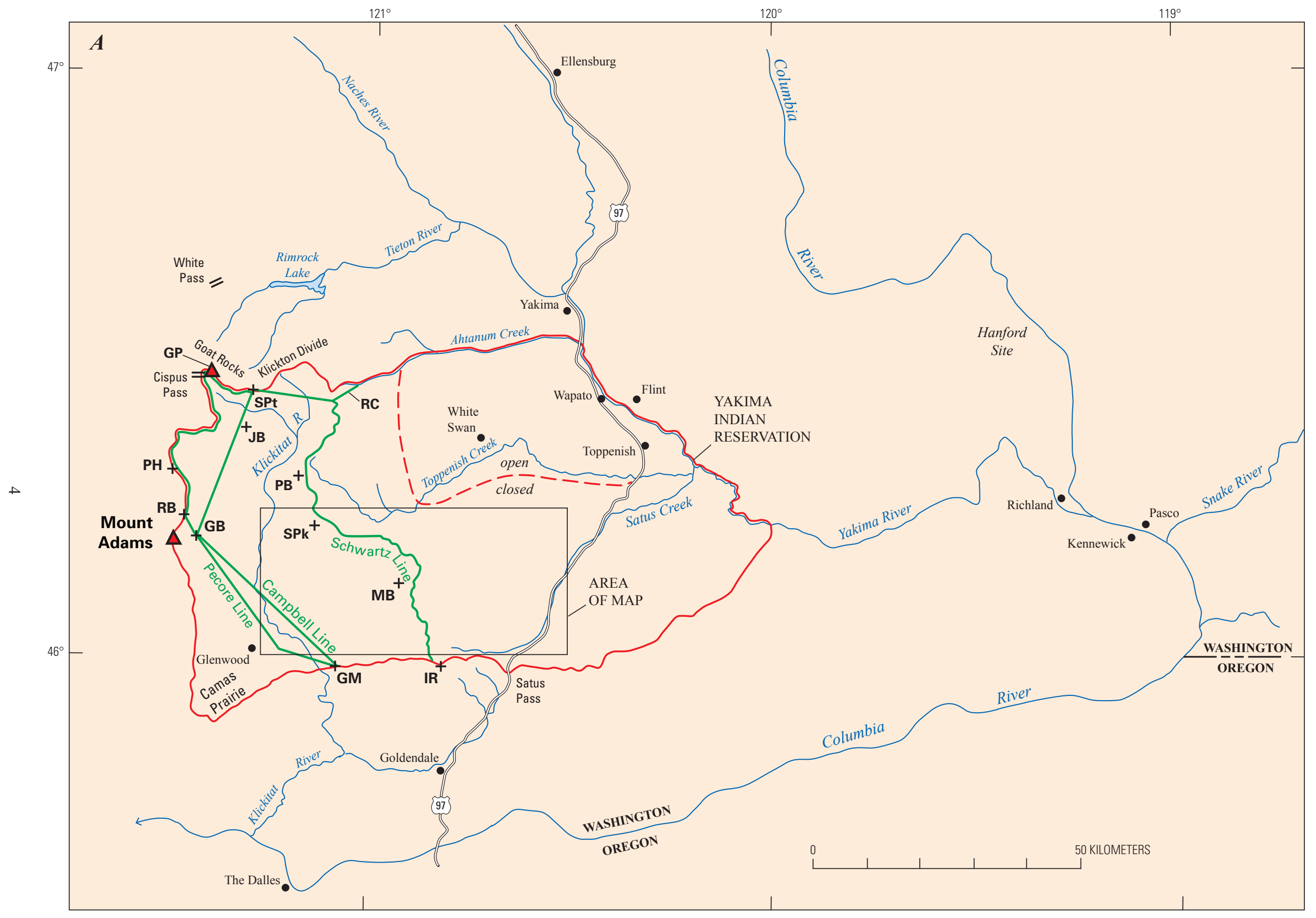

Figure 2.-Caption on following page. 


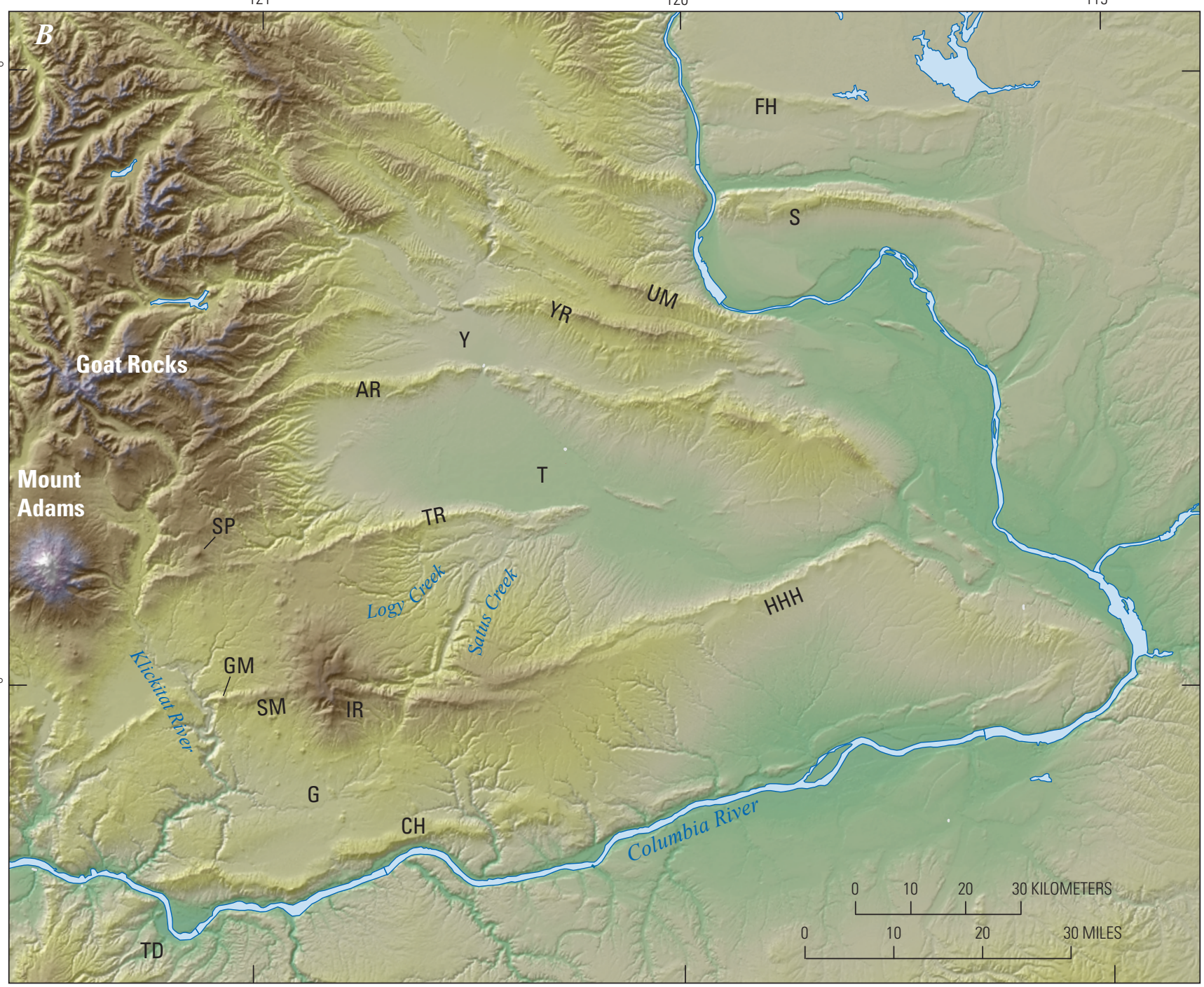

Figure 2. A, Map showing regional setting of map area and Yakama Nation in south-central Washington. Area of geologic map outlined as black rectangle. Yakima Indian Reservation outlined in red; boundaries as agreed in Treaty of 1855. Eastern boundary (Yakima River) and southern boundary as far west as Grayback Mountain (GM) were never in dispute. Schwartz Line, Campbell Line, and Pecore Line (all green) were surveyed as interim western boundaries, but they were never accepted by the Yakama Nation, which insisted on "the main ridge of the Cascade Mountains," which had been specified in the Treaty and validated in full by the Indian Claims Commission in 1966 and by Executive Order in 1972. Much of reservation is a "Closed Area" restricted to tribal members and permitees; unrestricted "Open Areas" are the northeast sector (as roughly enclosed by red dashed line) and the Glenwood area (southwest of Campbell Line). North and Central segments of Simcoe Mountain volcanic field (fig. 1) are almost entirely within Closed Area between Highway 97 (Satus Creek) and Klickitat River; south segment lies largely on private lands between southern boundary and Goldendale. Abbreviations: GB, Goat Butte; GM, Grayback Mountain; GP, Gilbert Peak; IR, Indian Rock; JB, Jennies Butte; MB, McKays Butte; PB, Panther Butte; PH, Potato Hill; RB, Red Butte; RC, Reservation Creek; SPk, Signal Peak; SPt, Spencer Point. $\boldsymbol{B}$, Regional physiography as digital elevation model, illustrating transition from rugged Cascade Range to Yakima Fold Belt. Abbreviations for selected anticlines in Yakima Foldbelt: AR, Ahtanum Ridge; $\mathrm{CH}$, Columbia Hills; FH, Frenchman Hills; HHH, Horse Heaven Hills; S, Saddle Mountains; SM, Simcoe Mountains; TR, Toppenish Ridge; UM, Umtanum Ridge; YR, Yakima Ridge. Other abbreviations: G, Goldendale; GM, Grayback Mountain; SP, Signal Peak; T, Toppenish (Yakama Nation headquarters); TD, The Dalles; Y, Yakima. Map area, as outlined in figure $2 A$, is drained principally by Toppenish, Logy, and Satus Creeks and Klickitat River. 
There are no permanent residents within the Closed Area. In Brendale v. Yakima Nation, the U.S. Supreme Court (1989) noted that the Treaty of 1855 between the United States and the Yakama Nation provided that the Tribe would retain its reservation for its exclusive use and benefit, and that no white man shall be permitted to reside upon the said reservation without the Tribe's permission. The Court ruled that the Tribe can define the essential character of the Closed Area and that it remain an undeveloped refuge of cultural and religious significance, a place where members may camp, hunt, fish, and gather roots and berries in the tradition of their culture.

\section{Physiography, Environment, Boundary Surveys, and Access}

The western margin of the Simcoe Mountains volcanic field is essentially the Klickitat River, an important regional drainage since Pliocene time (figs. 2, 3). The west side of the Klickitat River valley is dominated by the middle and late Pleistocene Mount Adams volcanic field (Hildreth and Fierstein, 1995) and includes only a few older basaltic units attributable to the Simcoe field. The eastern margin of the volcanic field is generally close to Highway 97 (fig. 2), which crosses the Simcoe Mountains Anticline at Satus Pass and thence follows Satus Creek northeastward.

The southern part of the volcanic field is drained southward to the Little Klickitat River, which flows westward to the Klickitat (figs. 2, 3). The northern third drains either directly into the upper Klickitat River or eastward into forks of Toppenish Creek, which (like Satus Creek) ultimately joins the Yakima River far to the east. The central part, mapped here, is largely confined by the anticlines on the north and south but is also bisected by a north-trending chain of volcanic centers that forms a drainage divide between numerous tributaries of the Klickitat River and Satus Creek (figs. 2, 3).

Elevations of volcanic plateaus are generally 2,100-3,800 $\mathrm{ft}(650-1,150 \mathrm{~m})$ above sea level in the central part but as high as 4,600-5,250 $\mathrm{ft}(1,400-1,600 \mathrm{~m})$ in the northern part. Because the base map is contoured exclusively in feet, we cite elevations accordingly, but all other measurements cited are metric. The southern part of the volcanic field slopes southward from a high of 5,823 $\mathrm{ft}(1,775 \mathrm{~m})$ atop the anticline to $\sim 1,600 \mathrm{ft}(500 \mathrm{~m})$ near Goldendale and to $1,100 \mathrm{ft}(330 \mathrm{~m})$ farther downstream on the Little Klickitat River. From the central highlands, intracanyon lava flows descend to elevations as low as $1,700 \mathrm{ft}$ (520 m) along Satus Creek, 1,300 ft (400 m) along Logy Creek, and $800 \mathrm{ft}(250 \mathrm{~m})$ along the Klickitat River gorge.

Many volcanic cones have local relief of $75 \mathrm{~m}$ to 250 $\mathrm{m}$, and the Signal Peak Shield has $500 \mathrm{~m}$. High points in the volcanic field (fig. 3) are at Indian Rock (5,823 ft; 1,775 m), a basaltic shield atop the southern anticline; Castle Rock $(5,656$ $\mathrm{ft} ; 1,724 \mathrm{~m})$, a basaltic shield just north of upper Satus Creek; Signal Peak (5,100 ft; 1,555 m), a mafic shield close to the Peavine Ridge Anticline; and Jennies Butte (6,410 ft; 1,954 m), a dacite cone in the northwestern headwaters of the Klickitat River (fig. 2).
Climatically, the area is marked by hot dry summers and cold wet winters. The volcanic field is largely forested, except for semi-arid grasslands along its eastern margin and agricultural fields near the town of Goldendale. The only other settlements nearby are Glenwood, $5 \mathrm{~km}$ southwest of the Klickitat River, and White Swan, $20 \mathrm{~km}$ northeast of the volcanic field; both towns are in lowland valleys outside the volcanic highland, at elevations of $1,895 \mathrm{ft}(578 \mathrm{~m})$ and $968 \mathrm{ft}$ $(295 \mathrm{~m})$, respectively. Average annual precipitation is $80 \mathrm{~cm}$ (31.6 in) at Glenwood, declining drastically eastward to only 22 $\mathrm{cm}$ (8.8 in) at White Swan. Average annual snowfall is strongly concentrated in December through February-154 cm (60.5 in) at Glenwood and $80 \mathrm{~cm}$ (31.7 in) at White Swan. Average minimum and maximum daily temperatures at Glenwood are 22 and $36^{\circ} \mathrm{F}$ in December and 42 and $80{ }^{\circ} \mathrm{F}$ in July and August; at White Swan, they are 19 and $37^{\circ} \mathrm{F}$ in January and 50 and 87 ${ }^{\circ} \mathrm{F}$ in July and August. A temporary station (3,146 ft; $\left.959 \mathrm{~m}\right)$ near Satus Pass, just east of the volcanic field, gave multi-year averages of $54.6 \mathrm{~cm}$ (21.5 in) of precipitation and $76.5 \mathrm{~cm}(30.1$ in) of snowfall. Temporary records for Signal Peak $(5,100 \mathrm{ft}$; $1,555 \mathrm{~m}$ ) gave average annual precipitation of $81 \mathrm{~cm}$ (32 in). Much of the volcanic field is snow-covered in the winter and muddy in the spring. There were no significant glaciers here during the Pleistocene, though there may have been two small northeast-facing ice slopes.

The Klickitat River Basin drains Mount Adams, the Goat Rocks, and more than half of the Simcoe Mountains volcanic field. The basin encompasses an area of $3,360 \mathrm{~km}^{2}$, of which $\sim 58$ percent $\left(1,940 \mathrm{~km}^{2}\right)$ is within upstream territory of the Yakama Nation. Where it leaves the Yakama southern boundary near the confluence of Summit Creek (fig. 3), the Klickitat has an average annual discharge of $34 \mathrm{~m}^{3} / \mathrm{s}$ (1,200 cfs), equivalent to 870,000 acre-ft/yr $\left(1.07 \times 10^{9} \mathrm{~m}^{3} / \mathrm{yr}\right)$. About 60 percent of this is groundwater discharge rather than surface runoff (Cline, 1976). Discharge originating on Yakama lands upstream accounts for $\sim 75$ percent of the annual flow reaching the mouth of the Klickitat and more than 90 percent of average low-flow discharge in summer months.

Confined between the anticlinal ridges, Satus Creek Basin $\left(\sim 1,840 \mathrm{~km}^{2}\right)$ drains the entire east side of the central part of the volcanic field (figs. 2, 3). Its long-term average annual discharge is $\sim 100,000$ acre- $\mathrm{ft} / \mathrm{yr}\left(123 \times 10^{6} \mathrm{~m}^{3} / \mathrm{yr}\right)$, including that of its major tributaries, Logy and Dry Creeks (Mundorff and others, 1976; Molenaar, 1977). Variability is great, however, as annual discharge has fluctuated in the tenfold range 31-293 $\mathrm{x} 10^{6} \mathrm{~m}^{3} / \mathrm{yr}$. Recharge for Satus, Logy, and Dry Creeks is dominated by the permeable volcanic highland, as downstream reaches of all three are incised into semi-arid plateaus of the far less permeable Miocene flood basalt. Discharge is greatest from December to April but is sustained by highland snowmelt through June. Satus and Logy Creeks, which head high on the crest of the Simcoe Mountains, are perennial, but Dry Creek, which starts lower and is predominantly cut on the Miocene basalt, usually goes dry from August to October.

North of the Toppenish Ridge Anticline, Toppenish Creek Basin $\left(\sim 1,625 \mathrm{~km}^{2}\right)$ drains the east side of the northern segment of the volcanic field, as well as a large tract of the Miocene 


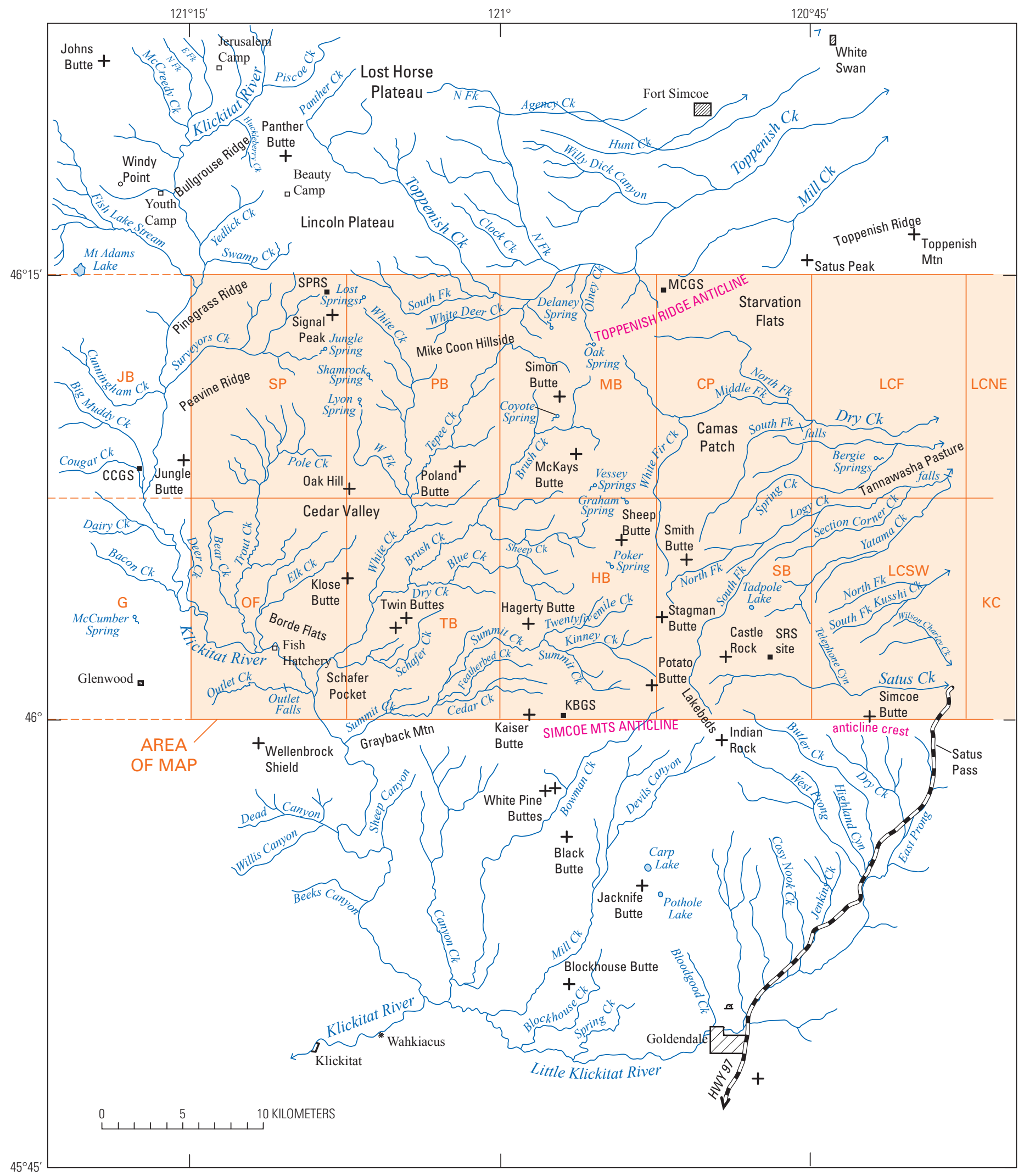

Figure 3. Map showing drainage of Simcoe Mountains volcanic field and vicinity, including locations of geographic names mentioned in text and in Description of Map Units. Abbreviations: CCGS, Cougar Creek Guard Station; KBGS, Kaiser Butte Guard Station; MCGS, Mill Creek Guard Station; SPRS, Signal Peak Ranger Station; SRS, site of Satus Ranger Station. Areas of geologic map (shaded) and constituent quadrangles are outlined. Abbreviations for quadrangle names: CP, Camas Patch; G, Glenwood; HB, Hagerty Butte; JB, Jungle Butte; KC, Kusshi Creek; LCF, Logy Creek Falls; LCNE, Logy Creek NE; LCSW, Logy Creek SW; MB, McKays Butte; OF, Outlet Falls; PB, Poland Butte; SB, Stagman Butte; SP, Signal Peak; TB, Twin Buttes. 
basalt flows (figs. 2, 3). Less than 10 percent of the drainage basin is covered by Simcoe flows, principally Lincoln Plateau in the southwestern headwaters. Average annual streamflow from the highlands was estimated to be $187 \times 10^{6} \mathrm{~m}^{3} / \mathrm{yr}(152,000$ acre-ft/yr) (U.S. Geological Survey, 1975; Gregg and Laird, 1975), including principal tributaries (Simcoe, Agency, and Mill Creeks) as well as the forks of Toppenish Creek proper. Low flow is typical from July to October, and peak runoffs usually take place in January-February and April-May, both intervals marked by occasional flash floods.

An extensive survey of the quality of surface and ground waters throughout Yakama lands was undertaken by Fretwell (1977). Although most of the data concerned streams, springs, and wells in irrigated lowlands outside the volcanic field, 18 mountain streams were also sampled. All had low totaldissolved-solids contents in the range of 48-116 mg/L, and their waters were all classified as "soft," defined as containing 0-60 mg/L of $\mathrm{CaCO}_{3}$. Principal dissolved constituents were invariably bicarbonate, silica, and $\mathrm{Ca}$. Contents of $\mathrm{F}, \mathrm{Cl}, \mathrm{SO}_{4}$, $\mathrm{Na}, \mathrm{K}, \mathrm{Mg}$, and heavy metals were low. Only Logy Creek and a few springs were bacteriologically suspect, probably owing to grazing cattle. Only Outlet Creek, which drains irrigated farmlands and marshes near Glenwood, had marginally inadequate dissolved oxygen. And turbidity was well below levels harmful to fish life, at least in the absence of active streamside logging. The selective (non-clearcut) logging practiced on most Yakama lands seldom affects the streams. Suspended-sediment transport is relatively low (Boucher, 1975) and typically attributable to landslides, downslope soil creep, sloughing of road embankments, and streambank erosionespecially during uncommon downpour-induced floodflows.

The volcanic field is largely forested but has scattered open meadows, which are either swampy or on the rocky surfaces of lava flows from which loess and soil have been deflated. Only the distal few kilometers of extensive Simcoe lava flows extend northeast beyond the forest onto the semiarid sagebrush-bunchgrass plateaus, which are largely gentle dipslopes on the Miocene flood basalt. The principal trees are ponderosa and lodgepole pines; Douglas, white, and grand firs; and western larch. Engelmann spruce, western white pine, and western hemlock are subordinate or locally concentrated, with cottonwoods and willows along the draws.

Common mammals include deer and elk, black bear and cougar, coyotes and bobcats, jackrabbits and porcupines, and squirrels and chipmunks. Present but less often seen are otter, marten, and weasels, rare wolverines, and (in the far northwest) mountain goats. Rattlesnakes are startlingly abundant on the eastern plateaus and along the Klickitat River gorge; on several spring days we encountered as many as ten. Noteworthy big birds include sandhill cranes, sage grouse, spotted owls, ravens, eagles, and hawks. Scattered herds of cattle are trucked in and left for the summer to range freely over some parts of the volcanic field before autumn roundups. Numerous herds of feral horses range freely along the eastern edge of the central segment of the volcanic field and on the dry plateaus farther east. There are no lakes and only a few stockponds in the mapped central segment, but Howard and Fish Lakes adjoin the northern segment, and the southern segment has small maar craters that contain Carp and Pothole Lakes (fig. 3).

The central segment detailed in this report, and the entire northern segment as well, now lie within the boundaries of the Yakama Reservation (fig. 2), but affirming those boundaries has a long complex history. Although Native Americans had occupied the region for millennia, conflict with encroaching European settlers led to a multi-tribal council with the U.S. Treaty Commission at Walla Walla in 1855. The Yakama ceded $44,000 \mathrm{~km}^{2}$ of their traditional territory to the United States, while retaining the right to fish, hunt, and gather on the ceded lands and agreeing to relocate onto a reservation of $\sim 5,500 \mathrm{~km}^{2}$ where they would receive Federal benefits. After violations and second thoughts, armed resistance was suppressed in the Yakima War of 1855-1858, the Yakima Indian Agency was established at Fort Simcoe in 1859, and most members of 14 tribes and bands consolidated there. The eastern and southern boundaries of the newly established reservation, the Yakima River and the Horse Heaven Hills/Simcoe Mountains Anticline, respectively, were never seriously in doubt, and the southern line was surveyed (by Berry and Lodge) in 1861 along the anticlinal crest as far west as Grayback Mountain (fig. 2). Although the Treaty map was suspiciously misplaced (and not found until 1930), the terms of the Treaty were clear enough that the western boundary runs "southerly along the main ridge of the Cascade Mountains, passing south and east of Mount Adams ..."

European settlement of the Glenwood valley began in 1872, and cattle and sheep were being run in Cedar Valley (fig. 3) east of the Klickitat River by the 1880s. When the first U.S. survey of the western boundary was conducted in 1890, George A. Schwartz ran a crooked line from Indian Rock via Panther Butte to Reservation Creek, approximately along the divide between the Klickitat River and Toppenish Creek, roughly $30 \mathrm{~km}$ east of the "main ridge of the Cascade Mountains." When the Yakama objected, USGS topographer E.C. Barnard was sent to investigate the "Schwartz Line" (fig. 2) in 1899 and recommended to the Department of the Interior that some $1,448 \mathrm{~km}^{2}$ be restored to the reservation. In 1904 , Congress acted to restore 82 percent of this, citing the "erroneous boundary survey" of 1890 . Accordingly, a new Federal survey by Campbell, Germond, and Long in 1906-7 established the "Campbell Line," a western boundary consisting of linear segments from Grayback Mountain to Goat Butte and from Goat Butte to Spencer Point on the Klickton Divide (fig. 2). In further litigation, the U.S. Supreme Court (1913) ruled that this boundary still fell short of the "main ridge of the Cascade Mountains" and thus had to be extended. Accordingly, C.W. Pecore surveyed yet a new line in 1920-24 that ran west from Spencer Point to the Goat Rocks, thence south along the Cascade crest via Cispus Pass, Potato Hill, and Red Butte to Goat Butte. Pecore also added a triangular wedge south of the Campbell Line by surveying straight boundary lines from Goat Butte and Grayback Mountain that converged at Outlet Creek. The "Pecore Line" (fig. 2) restored the reservation by a further $193 \mathrm{~km}^{2}$.

When the original Treaty map of 1855 was discovered in government archives in 1930, it made clear that the reservation 
boundary was indeed meant to pass through Mount Adams and to continue "south and east of Mount Adams," so the Department of the Interior again reinvestigated its prior surveys. Eventually, the Indian Claims Commission (1966) approved the Yakama claim to "Tract D," a 490- $\mathrm{km}^{2}$ triangular area that includes the southeast sector of Mount Adams and the Camas Prairie-Glenwood valley (fig. 2). The new boundary, encompassing Tract D southwest of the Pecore Line, extends $35 \mathrm{~km}$ southward from Mount Adams summit along the drainage divide, thence northeastward to Grayback Mountain along another divide southeast of Camas Prairie. This most recent decision placed within the reservation boundary the farm-based community of Glenwood, which has a population of $\sim 500, \sim 80$ percent non-Indian. The northernmost $85 \mathrm{~km}^{2}$ of Tract D had been federally owned and was restored to the reservation by Executive Order 11670 in 1972; the Yakama have since administered this parcel as the Mount Adams Recreation Area. More than 80 percent of Tract D, principally the Glenwood valley, had passed into non-Indian private ownership in the 19th century.

As a result of the Schwartz survey of 1890 , no more than 10 percent of the Simcoe Mountains volcanic field was within the reservation. After nearly a century of stepwise vindication of Yakama claims, the northern and central segments of the volcanic field now lie entirely within it. The southern segment, which today consists largely of privately held residential, forest, and farm land, was ceded by the 1855 Treaty and has not been disputed.

The central and northern parts of the volcanic field have very few buildings and no year-round habitation, although logging, hunting, and seasonal encampments are common. A fine highway, extensively blacktopped, connects White Swan with Glenwood, and several good gravel roads crisscross the area, providing access to a network of secondary logging roads.

Access is restricted, however. For entry to the central and northern segments of the volcanic field, one must be granted a written permit by the Tribal Council, Yakama Nation, headquartered in Toppenish, Washington. Gaining access to the privately held southern segment can be even more complicated, as many plots are fenced farmland, and large areas are controlled by logging companies and investment groups that require permits to pass locked gates.

Even within the Yakama Reservation, irrespective of the boundary disputes, the history of land ownership is long and complex. Paternalistic federal programs recurrently failed to curtail communal traditions and transform Indians into family farmers. Most disruptive was the Dawes Act of 1887, which accelerated allotment programs that broke up tribal holdings, assigned parcels to individual Indian families, weakened tribal government, and opened "surplus lands" on reservations to settlement by non-Indians. As throughout Indian Country, such homesteading and the inevitable condemnation or purchase of the best allotments by non-Indians soon turned much of the Yakama Reservation into a checkerboard of mixed ownership. In 1934, the disastrous allotment program was terminated, the reservation closed to further homesteading, and the remaining "surplus lands" restored to the Yakama Nation.

Established in 1910, the Forestry Branch of the Indian Service (later Bureau of Indian Affairs, BIA) hired summer forest guards who built trails, cabins, phone lines, fire lookouts, and ranger stations for fire suppression. After 1934, the Indian Division of the Civilian Conservation Corps (CCC) constructed roads and bridges, improved springs, and undertook forest projects to control fire and insect infestation. Because of remoteness and poor access, however, logging remained limited to a few allotments prior to 1948 , when large-scale timber sales and commercial logging began, at first by non-Indian companies under contracts managed by the BIA. Most of the road network on the reservation was constructed between 1950 and 1980 in support of the timber industry. Since the 1950s, logging has provided a large share of the employment and income for the Yakama Nation, which was thus enabled to establish a Land Purchase Program that aims to recover much of the 150,000 acres of former trust land that had been sold or given to non-Indians.

In part owing to the troublesome history of land alienation and exploitation, the Yakama Nation in 1954 designated roughly two-thirds of the reservation a Closed Area (fig. 2; formally the "reservation restricted area") with access limited to enrolled members, owners of remaining inholdings, and approved permittees. Seeking to control the character of the Closed Area, the Yakama Nation wishes that it remain an undeveloped refuge of cultural and religious significance, a place where members may camp, hunt, fish, and gather roots and berries in the traditions of their culture. Repurchase and consolidation of alienated lands continues today, parcel by parcel.

In 2001, $113 \mathrm{~km}^{2}$ of forest land in the Cedar Valley district (fig. 3) of the Closed Area was recovered from a timber company that had previously consolidated the properties of numerous former non-Indian homesteaders. The Yakama Nation has gradually taken over from the BIA much of the operation and management of the timber industry on the reservation, incorporating Yakama Forest Products in 1995 and opening its own sawmill at White Swan in 1998. The Yakama Nation had 9,600 enrolled members in 2002 and 10,190 in 2011.

The Yakima River, county, and city are spelled according to Euro-American tradition. In 1994, the Yakama Nation formally adopted (for its lands and people) what members regard as spelling appropriate to the original pronunciation.

\section{Previous Geologic Work}

No detailed work has previously been undertaken on the Pliocene-Pleistocene volcanic rocks of the Simcoe Mountains volcanic field. Sheppard (1967a) generalized the peripheral contact of the volcanic field with the underlying Miocene flood basalt in the southern and central segments, and he mapped the locations of numerous scoria cones and a few rhyolites. The structure and stratigraphy of the folded and faulted Miocene flood basalt were mapped by Swanson and others (1979a), Bentley and others (1980, 1988), and Anderson (1987a, b), all of whom treated the Simcoe lavas as a single unit. Much of the southern segment was reconnoitered by Anderson (1987b) 
and Uto and others (1991), and the western margin of the central segment is included on the Mount Adams geologic map of Hildreth and Fierstein (1995). All data available by 1987, unpublished and published, were compiled for the state geologic map (Walsh and others, 1987).

\section{Methods}

We spent one or two months each summer from 2000 to 2009 mapping the central segment of the volcanic field. About 350 days were devoted to productive fieldwork, excluding travel to and from our California office. Because most of the area is forested, deeply weathered, and heavily loess-covered, aerial photographs were of little use, and our detailed mapping was time consuming, footwork-intensive, often tedious, and done directly on USGS 1:24,000 topographic quadrangle maps. Our goal was to study in detail the volcanic history of a complete east-to-west strip across the heart of the volcanic field - the large central area, which is replete with eruptive vents. The resulting strip map consists of 12 quadrangles, in two tiers of six (fig. 3). Mapping of the northern area, which contains fewer but larger centers, is underway and will be treated in a subsequent report.

One or several thin sections for each of 223 volcanic units delineated were examined microscopically, and the observations are summarized below in the unit descriptions. One sample, or more, of every unit was analyzed chemically; the data are provided in appendix A at http://pubs.usgs.gov/sim/3315/.

For some of the eruptive units defined here, radioisotopic ages were determined in the USGS geochronology laboratory at Menlo Park, California, supervised by A.T. Calvert. Many of the samples were dated using ${ }^{40} \mathrm{Ar} /{ }^{39} \mathrm{Ar}$ incremental heating techniques following methods described in Calvert and Lanphere (2006) and Muffler and others (2011), and the results are listed in table 1. Samples were irradiated at the U.S. Geological Survey reactor in Denver, Colorado, using 27.87 Ma Taylor Creek sanidine as a neutron flux monitor. Weighted mean plateau ages, isotope correlation (isochron), and total gas ages are reported, and the interpreted preferred eruption age is highlighted in bold font (table 1). Plateau ages are generally interpreted as most reliable, if the ${ }^{40} \mathrm{Ar} /{ }^{36} \mathrm{Ar}$ intercept is within analytical error of atmospheric argon $\left({ }^{40} \mathrm{Ar} /{ }^{36} \mathrm{Ar}_{\mathrm{i}}=295.5\right)$. Isochron ages are generally interpreted as more reliable if the ${ }^{40} \mathrm{Ar} /{ }^{36} \mathrm{Ar}$ intercept is outside analytical error of atmospheric argon. Total gas ages are generally interpreted as most reliable for fine-textured samples with evidence for significant ${ }^{39} \mathrm{Ar}$ recoil. Ages for several other samples were determined by the K-Ar method (appendix B) following procedures described by Hildreth and Lanphere (1994).

\section{Geologic Setting}

We provide overviews of (1) the plate-tectonic framework of the volcanic field, (2) the basement rocks that underlie the Simcoe Mountains volcanic field, and (3) the Mount Adams volcanic field that adjoins it on the west.

\section{Tectonic Framework}

The Simcoe Mountains intraplate volcanic field overlies the southwestern part of the Yakima Foldbelt, a province of roughly east-west-trending anticlines that developed since middle Miocene in the thick pile of flood basalt of the Columbia River Basalt Group (CRBG). The 205 Pliocene and Quaternary exposed vents scattered across the volcanic field lie 135-175 km west of the foot of the Palouse Slope and 15-55 $\mathrm{km}$ east of the Quaternary axis of the Cascade volcanic arc (fig. 4). The Palouse Slope is a gently west-dipping, relatively undeformed subprovince of the Columbia Plateau that bounds the Yakima Foldbelt on its east and is underlain (beneath $\sim 2$ $\mathrm{km}$ of CRBG flows) by the tapering and truncated edge of the craton (Reidel and others, 1994). Outboard of that edge, the foldbelt and the Cascade Arc are underlain by Paleozoic and Mesozoic accretionary terranes and sedimentary rocks of Tertiary basins. The Cascade Arc in southern Washington has been volcanically active since $\sim 40 \mathrm{Ma}$, and its Quaternary manifestation is a continuous axial chain of at least 150 separate volcanoes that trends northward from Mount Hood through Mount Adams and Goat Rocks as far north as Bumping Lake (figs. 1, 4). Mounts Rainier and St. Helens and the Indian Heaven and Portland (Boring) volcanic fields are volcanic loci that lie $25-90 \mathrm{~km}$ west of the Cascade axis (fig. 8 of Hildreth, 2007).

The Juan de Fuca slab subducts northeastward beneath southwestern Washington at about $4 \mathrm{~cm} / \mathrm{yr}$, but the inclined seismic zone is not detectable east of the Puget Lowland (fig. 4) owing to lack of earthquakes deeper than $70 \mathrm{~km}$. Early models of the slab by seismic tomography (Michaelson and Weaver, 1986; Rasmussen and Humphreys, 1988) depicted slab dips of $40^{\circ}$ to $65^{\circ} \mathrm{E}$. beneath the southern Washington Cascades, and they interpreted the slab to extend to depths as great as 300 $\mathrm{km}$. More recent models (McCrory and others, 2006) suggest a lesser dip, a slab depth of $\sim 100 \mathrm{~km}$ beneath Mount Adams, and uncertainty whether the slab extends farther east beneath the Simcoe Mountains.

Contemporaneous with growth of the Yakima Foldbelt, the Oregon forearc block (principally Siletzia; fig. 4) has been moving northward and rotating clockwise with a pole of rotation east of the foldbelt (Wells and others, 1998; McCaffrey and others, 2007). North-south shortening in the Puget Sound region today has its inboard counterpart in the foldbelt (Blakely and others, 2011) and in generally north-south arrays of vents in the Simcoe Mountains, Mount Adams, and Indian Heaven volcanic fields (Walsh and others, 1987; Hildreth, 2007). The crustal stress field changes across southern Washington, as the direction of maximum horizontal compression shifts from $\sim \mathrm{N}$. $30^{\circ}$ E. near and west of Mount St. Helens to essentially northsouth in the Mount Adams and Simcoe Mountains regions (Zoback and Zoback, 1991). Crustal thickness is estimated to be $\sim 40 \mathrm{~km}$ beneath the Yakima Foldbelt and 40-44 km beneath the adjacent Cascade Arc (Catchings and Mooney, 1988; Mooney and Weaver, 1989). 


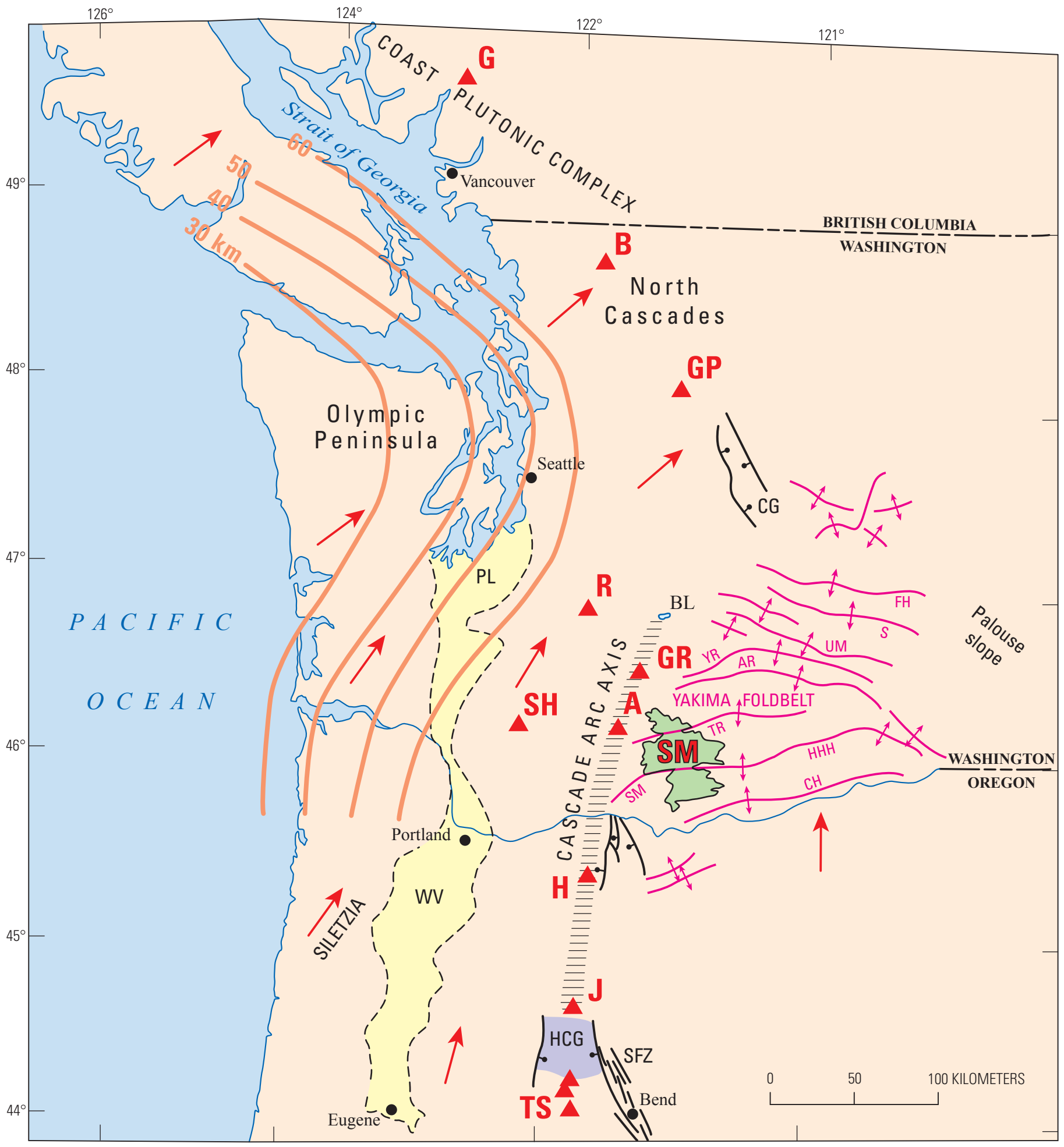

Figure 4. Map showing simplified tectonic map of Pacific Northwest, highlighting Simcoe Mountains volcanic field (green shading) draping southwest part of Yakima Foldbelt, east of Cascade Arc axis. Yakima anticlines after Reidel and others (1994). Subductingslab depth contours (30-60 km) after Crosson and Owens (1987). Red arrows depict rotation of Cascadia generalized from GPS data by McCaffrey and others (2007). Siletzia is an oceanic terrane accreted to the Oregon margin in the Eocene. Abbreviations (red) for major volcanic areas: A, Mount Adams; B, Mount Baker; G, Mount Garibaldi; GP, Glacier Peak; GR, Goat Rocks; H, Mount Hood; J, Mount Jefferson; R, Mount Rainier; SH, Mount St. Helens; SM, Simcoe Mountains volcanic field; TS, Three Sisters volcanic cluster. Abbreviations (magenta) for selected anticlines in Yakima Foldbelt as in figure 2B. Other abbreviations (black): BL, Bumping Lake; CG, Chiwaukum Graben; HCG, High Cascades Graben; PL, Puget lowland; SFZ, Sisters Fault Zone; WV, Willamette Valley. For broader tectonic setting, see figure 25 of Hildreth (2007). 


\section{Pre-Pliocene Rocks}

Underlying and peripheral to the Simcoe Mountains volcanic field are middle Miocene lava flows of the Columbia River Basalt Group, principally the Grande Ronde Basalt (16.015.6 Ma) and the Frenchman Springs, Roza, and Priest Rapids Members of the Wanapum Basalt (15.6-14.5 Ma) (Swanson and others, 1979b; Bentley and others, 1980; Hooper and others, 2007; Barry and others, 2010). The Saddle Mountains Basalt, comprising numerous smaller-volume units (13-6 Ma) of the CRBG, is largely missing here, either originally confined to paleo-lowlands by folding of earlier CRBG units or eroded from the area prior to eruption of Simcoe lava flows. Remnants of a few members are preserved along the Klickitat River gorge (near Summit Creek) and just east of the volcanic field (on plateaus flanking Dry, Logy, and Satus Creeks).

Pliocene sedimentary rocks (principally Ringold Formation) that overlie the Miocene basalts farther east are not present in the Simcoe Mountains volcanic field. Minor intercalations of fluvial volcaniclastic and siliciclastic sedimentary rocks (principally Ellensburg Formation) are present locally but poorly exposed (Bentley and others, 1980; Smith, 1988); a few such beds may be extensive enough to provide groundwater aquifers. Oligocene and Miocene arcvolcanic rocks that predate the CRBG are exposed beneath the extreme northwestern part of the volcanic field (Walsh and others, 1987) but not in the central and southern segments where pre-Pliocene exposures are almost exclusively CRBG.

The CRBG consists of hundreds of lava flows that erupted from fissures in eastern Washington, Oregon, and Idaho, covered $\sim 200,000 \mathrm{~km}^{2}$, and (if Steens basalt is included) represents at least $230,000 \mathrm{~km}^{3}$ of (largely tholeiitic) magma (Tolan and others, 1989; Camp and others, 2003). More than 98 percent of it erupted during the interval $\sim 17-14.5 \mathrm{Ma}$. In the western subprovince of the Columbia Plateau, which includes the Simcoe Mountains, the CRBG is as thick as $4-5 \mathrm{~km}$, but its base is exposed only at its western extremity where it banked up against the ancestral Cascade Range. This thick western CRBG subprovince is thought to overlie 4-7 km of Tertiary continental sedimentary rocks, which in turn rest on accreted terranes of Mesozoic age (Campbell, 1989; Reidel and others, 2003).

The CRBG of the western subprovince has been deformed by north-south compression into a set of 15 major and several minor anticlines that collectively form the $14,000-\mathrm{km}^{2}$ Yakima Foldbelt (Tolan and Reidel, 1989; Reidel and others, 1994). Narrow anticlinal ridges, mostly $50-180 \mathrm{~km}$ long and 2-10 km wide, separate broad flat-floored valleys. Most of the anticlines are asymmetrical and north-vergent, with steep forelimbs typically cut by reverse faults. The poorly exposed faults appear to dip $45^{\circ}-70^{\circ}$ beneath the folds and to shallow forward into imbricate thrusts where the steep limb overrides the low-relief limb of its neighboring syncline. The valleys are not true synclinal folds but are, instead, structurally low, nearly flat, areas between the steep limb of one anticline and the gently dipping limb of another. Most of the anticlines have less than $600 \mathrm{~m}$ of structural relief, but a few have as much as $1,000 \mathrm{~m}$. Total shortening across the foldbelt is $15-25 \mathrm{~km}$ $(\sim 5 \%)$, typically $1-1.5 \mathrm{~km}$ on each anticline (Reidel and others, 1994). Analysis of the development of paleostructural relief, based on thinning and wedging out of flood-basalt units and of intercalated and suprabasalt sediments, suggests that fold growth was already underway during the Grande Ronde eruptive interval (17-15.6 Ma). Much of the structural and topographic relief, however, is thought to have developed after 10.5 Ma, and growth of some folds persisted into the Pliocene (Reidel, 1984; Reidel and others, 1989).

The Simcoe Mountains volcanic field drapes the southwestern part of the Yakima Foldbelt. Two of the anticlines partition the field into its three principal segments, and a third (Ahtanum Ridge, outside the volcanic field) approximates the northern boundary of the Yakama Reservation (fig. 2A). Toppenish Ridge, Mike Coon Hillside, and Peavine Ridge are segments of the Toppenish Ridge Anticline, which is $\sim 85$ $\mathrm{km}$ long and 4-8 km wide, has structural relief of as much as $500 \mathrm{~m}$, trends $245^{\circ}-265^{\circ}$, and separates the volcanic field into its northern and central segments. Farther south, the Simcoe Mountains Anticline forms the ridge that separates the central and southern segments and approximates the southern boundary of the reservation and of our geologic map area. Here, it trends close to east-west, but west of the Klickitat River gorge, the anticline bends to a $230^{\circ}$ trend where it forms the southeast wall of Camas Prairie. Farther east, with slight structural offset, the anticline extends eastward as the Horse Heaven Hills for an additional $90 \mathrm{~km}$ to the Yakima River. Altogether, the segmented anticline is $\sim 180 \mathrm{~km}$ long, $2-7 \mathrm{~km}$ wide, and has as much as $800 \mathrm{~m}$ of structural relief. The Toppenish and Simcoe Mountains Anticlines are steep-sided, asymmetrical, north-vergent, and reversely faulted, and each represents $\sim 1$ $\mathrm{km}$ of shortening. Complex reverse and normal faulting of both anticlines was mapped by Swanson and others (1979a), Bentley and others (1980), and Anderson (1987a).

Crest to crest, the Simcoe Mountains and Toppenish Anticlines are $\sim 25 \mathrm{~km}$ apart. Between them, the gently eastdipping surface of the CRBG has $\sim 1,100 \mathrm{~m}$ of structural relief, and its highland western part provides the basement upon which the thickest and most complex part of the Simcoe Mountains volcanic field erupted. North of the Toppenish Anticline, the CRBG likewise slopes uniformly eastward at $3^{\circ}-5^{\circ}$, providing $\sim 1,800 \mathrm{~m}$ of structural relief (Swanson and others, 1979c), but only the extreme westernmost part is overlain by Simcoe lava flows. Near the northwest corner of the Simcoe Mountains volcanic field, the CRBG surface reaches elevations above $1,890 \mathrm{~m}(6,200 \mathrm{ft})$, reflecting uplift of the adjacent Cascade Range. Spacing between the Toppenish and Simcoe Mountains Anticlines and the neighboring anticlines to the north (Ahtanum Ridge) and south (Columbia Hills) is likewise $25-30 \mathrm{~km}$ (fig. 4), suggesting a provincial periodicity (Watters, 1989).

\section{Mount Adams Volcanic Field}

The Simcoe Mountains and Mount Adams volcanic fields are contiguous, overlapping only slightly in space and time (fig. 1). The main differences are compositional and temporal. Both are distributed basaltic volcanic fields marked by 
numerous vents that produced basaltic products that range from low-K tholeiitic through calc-alkaline to alkaline, but the Mount Adams field also built a $200-\mathrm{km}^{3}$ andesite-dacite stratovolcano at its central focus. Basaltic activity from $\sim 50$ peripheral vents, and andesite-dacite activity within a multi-vent focal area, have remained persistently contemporaneous throughout the 520,000-year lifetime of the stratovolcano. Volumetrically, however, only $\sim 15$ percent of the Mount Adams field is basaltic, whereas the Simcoe Mountains volcanic field is more than 80 percent basaltic.

Eruptive activity in the Simcoe field took place in three episodes (4.2-3.2 Ma; 2.2-1.2 Ma; and 1.0-0.6 Ma) while that in the Mount Adams field started $\sim 940 \mathrm{ka}$ and has persisted (without extended breaks) into the Holocene. After $\sim 3.5$ m.y. of fundamentally basaltic, distributed magmatism east of the Klickitat River, Simcoe Mountains activity died out, and the new Mount Adams field of distributed basaltic magma ascent started up west of the Klickitat River, representing (center to center) a 40-km westward shift. During the transitional interval (1,000-600 ka) when the shift was taking place, eruptions in both fields were fewer, scattered in space and time, largely mafic, and of modest volume (except for the extensive low-K tholeiite of Outlet Falls, unit bof). In the Simcoe Mountains volcanic field, there were no eruptions after $\sim 600 \mathrm{ka}$ and only $\sim 25$ during the interval 1,000-600 ka.

The Klickitat River canyon forms a general boundary between the slightly overlapping fields. Two basaltic units of Simcoe age (units bwb [3,440 $\pm 40 \mathrm{ka}]$ and bgo $[2,360 \pm 720$ ka]) erupted at vents west of the Klickitat River, as did six units of transitional age (1,000-900 ka) (Hildreth and Fierstein, 1995; Hildreth and Lanphere, 1994), but only unit bof (967 \pm 4 ka) was voluminous enough to backfill some of its east-bank tributaries. Several younger units (695-68 ka) of the Mount Adams field, which all erupted well west of the Klickitat River, flowed into and for various distances down its canyon.

The $\sim 205$ vents exposed in the Simcoe Mountains volcanic field are distributed over a 1,660- $\mathrm{km}^{2}$ area that extends $\sim 60$ $\mathrm{km}$ north-south and $40 \mathrm{~km}$ east-west, whereas the $\sim 70$ vents for the 1,250- $\mathrm{km}^{2}$ Mount Adams volcanic field are mostly arrayed along a north-south belt $50 \mathrm{~km}$ long but only 6-10 km wide (Hildreth and Fierstein, 1995). Our rough estimate of the eruptive volume of the entire Simcoe Mountains field is $200 \mathrm{~km}^{3}$, whereas Hildreth and Lanphere (1994) estimated an eruptive volume of $315 \pm 84 \mathrm{~km}^{3}$ for the Mount Adams field by summing estimates for 124 individual map units. About 85 percent of the Mount Adams products erupted from central or proximal flank vents and only $\sim 15$ percent from the field's numerous peripheral vents. Nonetheless, if $35-60 \mathrm{~km}^{3}$ of peripherally distributed Mount Adams lavas (largely basaltic) erupted over an interval of 940,000 years, that distributed eruption rate is rather similar to that of the Simcoe Mountains volcanic field, $\sim 200 \mathrm{~km}^{3}$ over $\sim 3.6 \mathrm{~m}$.y. The big difference between the fields is the growth of Mount Adams, second largest stratocone in the Cascade Range, representing excess mantle and crustal melting, apparently enhanced locally by slab-derived fluid contributions that were absent or attenuated beneath the Simcoe region farther inboard.
Although basaltic activity in the Mount Adams volcanic field has been essentially continuous since $\sim 940 \mathrm{ka}$ (Hildreth and Lanphere, 1994), the central andesite-dacite stratovolcano grew in three major pulses, centered at $500 \mathrm{ka}, 450 \mathrm{ka}$, and 35 ka. Although most of the cone's volume was produced by these pulses, the cone had scores of lesser eruptions between them. Since inception of the stratocone at $\sim 520 \mathrm{ka}$, the andesite-dacite central system never completely shut down, though breaks as long as 30,000 years are permitted by the K-Ar age data. Background eruption rates between pulses were at least an order of magnitude smaller than those of the pulses (Hildreth and Lanphere, 1994; Hildreth, 2007). Ten postglacial vents (15-1 ka) on and adjacent to Mount Adams, the nature and distribution of their basaltic and andesitic eruptive products, and the potential hazards of the Mount Adams volcanic field were described by Hildreth and Fierstein (1997).

Reaching an elevation of 3,742 m, the Mount Adams stratocone still sustains a summit icecap and 10 radial glaciers; during Pleistocene glacial episodes, ice advanced to the Klickitat River and far down several canyons to the west. Glaciation also affected the extreme northwestern part of the Simcoe Mountains volcanic field where it merges into the Goat Rocks, but the southern and central Simcoe segments, which lie farther inland and nowhere higher than $1,775 \mathrm{~m}$, remained unglaciated, with the probable exception of small leeside icefields at Lakebeds and uppermost Satus Creek. Immediately downwind from barren periglacial and outwash areas of Pleistocene Mount Adams, however, the Simcoe Mountains were blanketed with thick loess. While perhaps retarding freeze-thaw break-up and erosion, the loess cover has enhanced deep spheroidal weathering of Simcoe lavas and has widely diminished their exposure.

\section{Simcoe Mountains Volcanic Field}

The volcanic field is divided by two east-west anticlinal ridges into three segments (figs. 1, 4). We present an overview of the $950-\mathrm{km}^{2}$ central segment covered by the accompanying geologic map. Then we summarize our current knowledge of the $250 \mathrm{~km}^{2}$ of lava flows preserved in the deeply eroded northern segment and the $460 \mathrm{~km}^{2}$ of flows and cones that make up the southern segment, based on previous reconnaissance studies and our ongoing mapping.

\section{Central Segment}

The central segment includes $\sim 950 \mathrm{~km}^{2}$ of Pliocene and Pleistocene volcanic rocks, roughly 60 percent of the area of the whole Simcoe Mountains volcanic field. Its southern boundary coincides with that of the Yakama Reservation, running along the Simcoe Mountains crest from Satus Pass to Grayback Mountain. The northern boundary of the segment is the Toppenish Ridge-Mike Coon Hillside-Peavine Ridge basement anticline, but the geologic map extends slightly north of the anticline to include Signal Peak and parts of the canyons of Toppenish Creek. About 20 Simcoe vents are located on 
the two anticlines, and more than 110 vents are exposed in the 20-km-wide area between them (fig. 5).

The Description of Map Units (DMU) summarizes the distribution and lithologic characteristics of 223 eruptive units delineated within the map area. It also gives radioisotopic ages for many, stratigraphically relative ages for most, and compositional data for all. Along with $\mathrm{SiO}_{2}$ contents, the crystal "cargo" (phenocrysts, megacrysts, antecrysts, and xenocrysts) of each unit is given in the DMU. Chemical analyses of all units are listed in appendix A.

To clarify discussion, the central segment can conveniently be considered in terms of five swaths, numbered 1 to 5 in figure 5. North-south boundaries between swaths, though somewhat arbitrary, are based not on lava-flow distribution but on abundance and distribution of vents.

1. The eastern plateaus, which have only a few vents and principally consist of plateau-capping and intracanyon lava flows that erupted in the Simcoe highland

2. The Simcoe Mountains highland that divides the headwaters of numerous streams that flow either east into Satus Creek or west into tributaries of the Klickitat River. Principal components of the north-trending highland are the multi-vent shields centered near Indian Rock, Castle Rock, Satus Ranger Station (site), and Smith Butte, each of which produced numerous distinguishable eruptive units

3. A 10-km-wide north-trending central swath of especially high vent density, just west of the highland and central to the map area. From south to north, it includes Kaiser, Hagerty, Sheep, McKays, and Simon Buttes and many more scoria cones

4. A swath of lesser vent density east of White Creek that extends northward from Summit Creek to Mike Coon Hillside and includes Twin Buttes, Poland Butte, and a cluster of small cones between the headwaters of Tepee and White Creeks

5. A western belt, west of White Creek, that includes such shields as Oak Hill, Klose Butte, Jungle Butte, Signal Peak, and Lincoln Plateau, as well as a few shields west of the Klickitat River and a chain of lesser cones that divides the headwaters of White, Trout, and Pole Creeks

\section{Eastern Plateaus}

The eastern plateaus are capped by numerous mafic lava flows that erupted in or east of the highland and extended many kilometers eastward across a gently dipping surface of the CRBG, into which several steep-walled canyons have progressively been cut. Ten highland-derived units (47-57\% $\mathrm{SiO}_{2}$ ) extend $10 \mathrm{~km}$ or more onto the plateaus, where older ones (3.7-1.7 Ma) rest subhorizontally on the CRBG and younger ones ( $\sim 800 \mathrm{ka})$ funnel into medial-to-distal canyons. Basaltic lava flows from the Tadpole Lake Shield (unit byt, $674 \pm 4$ ka) extend $\sim 30 \mathrm{~km}$, nearly as far east as Highway 97, and are preserved as intracanyon remnants along Logy Creek. Four of the basaltic units survive as remnants along the canyon walls of Wilson Charley Canyon, and one of these (low-K tholeiitic unit bsa) continues from the canyon mouth for another $9 \mathrm{~km}$ down Satus Creek, alongside Highway 97.

Four basaltic spatter/scoria cones (units bbw, btw, b14, and b41) are exposed on the eastern plateaus, and all are bracketed by contiguous lava flows to have erupted $\sim 3.45 \mathrm{Ma}$. Three of the four vents (excluding bbw) produced aprons of lava flows that are preserved as far as 4 to $9 \mathrm{~km}$ eastward. The eastern swath also contains three rhyolitic units (rkc, rtc, rwc; $73-76 \% \mathrm{SiO}_{2}$ ) and an undated mafic scoria cone (unit b98 in Satus Creek canyon). Rhyolitic unit rtc is in part pyroclastic, and its age is constrained by those of bracketing basalts (units bys and bte) to 3.5 to $3.6 \mathrm{Ma}$. The other two rhyolites are lava flows that rest on the CRBG and are directly overlain by unit msr $(3,465 \pm 4 \mathrm{ka})$.

\section{Simcoe Mountains Highland}

The Simcoe Mountains highland (fig. 5) is the oldest, most lithologically varied, and most complexly dissected part of the volcanic field. Within the map area, the largest component of the highland is the mafic shield centered at Castle Rock (elevation 5,656 ft; 1,724 m) and augmented by mafic contributions from several lesser peripheral vents and a large vent at Cone 5659, $2 \mathrm{~km}$ southwest of Castle Rock. Radioisotopic ages for Castle Rock Shield flows range from 4.0 to $3.5 \mathrm{Ma}$ and overlap with those for the Indian Rock Shield (4.2-3.4 Ma), which vented just south of the map area where it is partly separated from the Castle Rock Shield by CRBG exposures along the crest of the Simcoe Mountains Anticline. Having vent complexes on opposite sides of the crest, the shield aprons are both unilateral, descending opposite limbs of the anticline. Both shields are cored by thick masses of rhyolite, 2 to $3 \mathrm{~km}$ wide, that intrude the CRBG; one is exposed in upper Satus Creek (units rsc and rel) and the other in Devils Canyon south of the crest. The Castle Rock Shield is gutted centrally by an amphitheater eroded at the head of Satus Creek, and the west flank of the shield is incised along a fault through Lakebeds and along the upper canyon of the South Fork Logy Creek.

Five parasitic shields (a-e) were later constructed on the upper flanks of the Castle Rock Shield, each also unilateral in the sense that each vent issued lavas that flowed downslope only in confined sectors $80^{\circ}$ to $150^{\circ}$ wide. Each is in itelf a significant edifice built upon a different sector of the original 4.0 to 3.5 Ma Castle Rock Shield. (a) The oldest shield is the Satus Ranger Station shield, flows of which (unit msr; $3,465 \pm 4 \mathrm{ka})$ extend from a vent intrusion at 1,463 $\mathrm{m}(4,800$ $\mathrm{ft}$ ) on the east flank (260 m lower than Castle Rock) for $9 \mathrm{~km}$ northeast and $11 \mathrm{~km}$ eastward. From beneath the distal limits of the msr-type flows, aprons of basaltic lava flows, slightly more mafic but of similar age, extend an additional 8 to 11

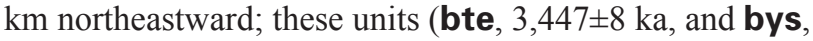




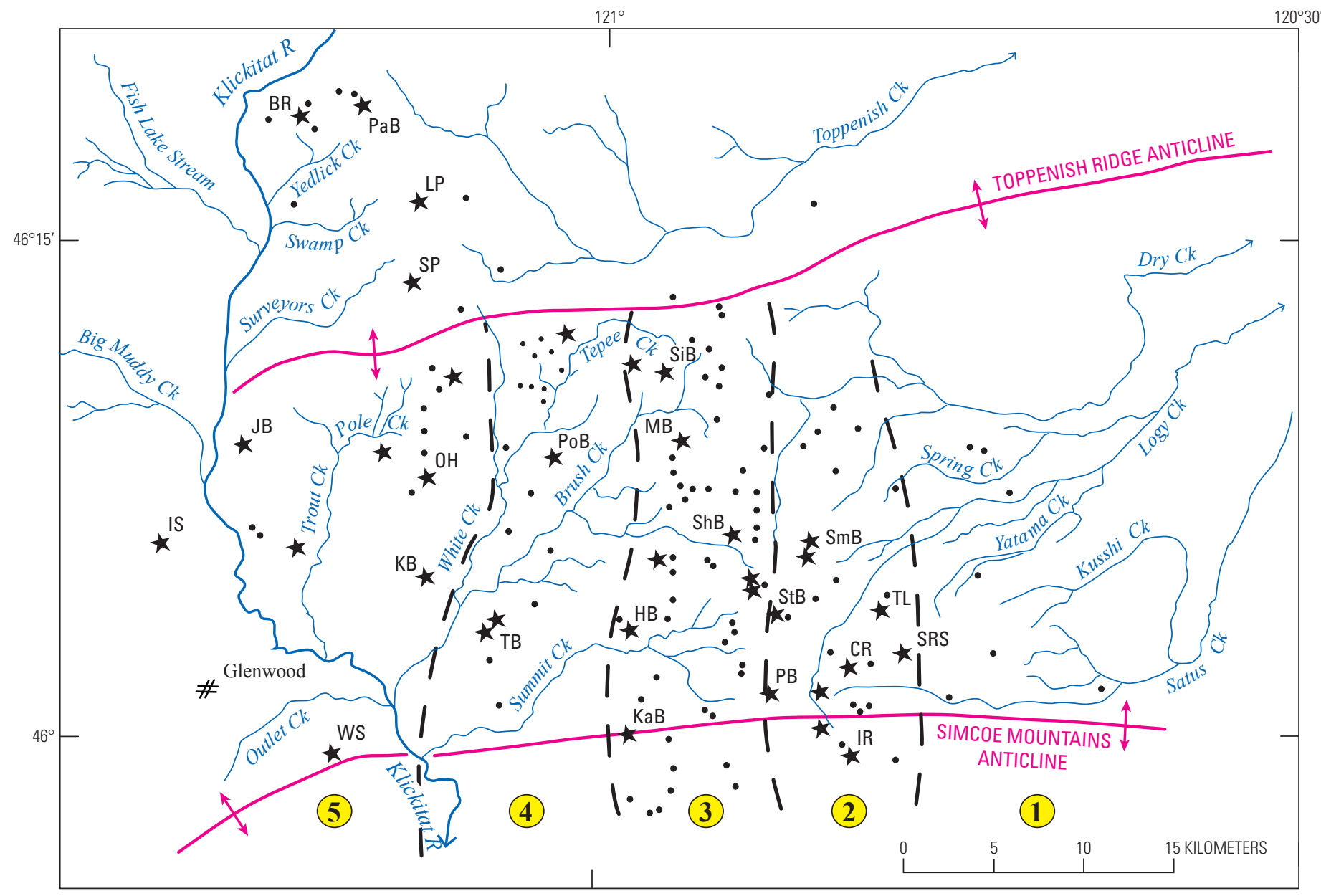

Figure 5. Vent locations for central segment of Simcoe Mountains volcanic field. Based on our mapping, 144 vents are depicted: stars $(\star)$ for substantial shields and dots $(\bullet)$ for monogenetic vents that produced scoria, spatter, lava flows, and a few domes. For convenient reference, central segment is discussed in terms of five arbitrary swaths, as elaborated in text: (1) eastern plateaus with few vents; (2) Simcoe Mountains highland with several productive shields; (3) central swath of high vent density; (4) swath of lesser vent density, centered on Brush Creek; and (5) western swath with several extensive shields (west of White Creek). Abbreviations for selected volcanoes: BR, Bullgrouse Ridge Shield; CR, Castle Rock Shield; HB, Hagerty Butte; IR, Indian Rock Shield; IS, Ilse Shield; JB, Jungle Butte; KaB, Kaiser Butte; KB, Klose Butte; LP, Lincoln Plateau Shield; MB, McKays Butte; OH, Oak Hill Shield; PaB, Panther Butte Shield; PB, Potato Butte; PoB, Poland Butte Shield; ShB, Sheep Butte; SiB, Simon Butte; SP, Signal Peak; SmB, Smith Butte; SRS, Satus Ranger Station Shield; StB, Stagman Butte; TB, Twin Buttes; TL, Tadpole Lake Shield; WS, Wellenbrock Spring Shield.

$3,667 \pm 27 \mathrm{ka}$ ) were probably early products of the Satus Ranger Station shield rather than from higher vents near Castle Rock. (b) On the west flank of the Castle Rock Shield, a prominent vent at Stagman Butte (elevation 1,575 m; 5,166 ft) built a smaller shield, basaltic flows of which (unit bsm; 2,045 $\pm 23 \mathrm{ka}$ ) form a $2.5-\mathrm{km}$-wide apron that extended $\sim 5 \mathrm{~km}$ downslope to the west. (c) On the north slope, Smith Butte (elevation 1,481 $\mathrm{m} ; 4,858 \mathrm{ft}$ ) is the vent for a major parasitic shield, the basaltic lava flows of which (units bs; $1,722 \pm 5 \mathrm{ka}$ ) descend $8 \mathrm{~km}$ north to Camas Patch and $11 \mathrm{~km}$ northeast to Tannawasha Pasture. Vents for several older aprons (including units bgp, bds, bsd, bsu, bta, and mns) are buried by the Smith Butte Shield. The highland terminates northward with a younger vent that grew on the north slope of Smith Butte, scoria Cone 4802, which produced a basaltic apron (unit bsn; 1,479 $\pm 3 \mathrm{ka}$ ) that descends $6 \mathrm{~km}$ northward to Camas Patch. (d) At the southwest margin of the highland, Potato Butte (unit bpb; $822 \pm 3 \mathrm{ka}$ ) produced aprons of aphyric basalt that descended several kilometers, both south and west. (e) The fifth and youngest of the parasitic shields vented at the Tadpole Lake Cone (elevation 1,562 m; $5,125 \mathrm{ft}$ ) and at nearby fissures on its northeast flank. An apron of lava flows (unit byt; $674 \pm 4 \mathrm{ka}$ ) spread $6 \mathrm{~km}$ northward, and a few of them advanced $30 \mathrm{~km}$ northeastward down the canyons of Yatama Creek and then Logy Creek.

On the north slope of the highland are seven small scoria cones (units bc2, bc5, bc6, bc8, b47, m46, and brs) that rise near and south of the meadows called Camas Patch. All seven are basaltic, and all but unit brs are older than 1.88 to $1.72 \mathrm{Ma}$ highland-derived lava flows (units bs and bcs) that overlap or surround them. Also cropping out around the north and east sides of the highland are several additional units of mafic lava (bcf, bfr, bln, bnl, bsd, bxc, mcc, mnf, msg, and mxc) 
that erupted from highland vents now buried by younger flows of the shields. Altogether, 18 vents are identified within the highland, and at least 27 more are inferred to be buried there. Also within the north-south swath are the lowland mafic vent cluster at Camas Patch and a highland cluster of basaltic vents near Indian Rock, just south of the map edge. Rhyolite lava (unit ret; $73.1-73.5 \% \mathrm{SiO}_{2}$ ) crops out in three small windows through shield flows east of Tadpole Lake.

\section{Central Swath of High Vent Density}

The central swath of high vent density (fig. 5) stretches $24 \mathrm{~km}$ north-south from anticline to anticline and is roughly $10 \mathrm{~km}$ wide. It is bordered by the highland to the east, drained westward by forks of Tepee, Brush, Sheep, Blue, Twentyfive Mile, Summit, Featherbed, and Cedar Creeks (fig. 3), and grades westward into a belt of lesser vent density that extends another 8 to $9 \mathrm{~km}$ west to White Creek (fig. 5). Altogether in the central swath, 58 vents have been recognized and another 9 inferred for distinctive eruptive units that are buried proximally by younger lava flows. Because vents for Potato and Stagman Buttes are on the western slope of the highland, their swath assignment is ambiguous, but their extensive lava aprons are largely within this swath. Kaiser and Potato Buttes are on the crest of the Simcoe Mountains Anticline, as are vents for basaltic units $\mathbf{b 5 8}$, bbc, and bps. At the north end of the swath, vents for units bth and bts are high on the Toppenish Ridge Anticline, and the vent for unit beo is just north of it. Most vents are in the lowland between anticlines, where some are small shields typically capped by scoria/spatter cones, and many are such cones that fed lava tongues limited to narrow sectors. Most lava flowed westward or southwestward, although Cone 3925 issued flows (unit bnf; 1,533 $\pm 3 \mathrm{ka}$ ) that extended both 4 $\mathrm{km}$ west and $10 \mathrm{~km}$ east, banked along the southern toe of the Toppenish Ridge Anticline.

Among the largest cones in the central swath are McKays Butte and Simon Butte, with $250 \mathrm{~m}$ and $200 \mathrm{~m}$ relief, respectively; each produced a lava-flow apron that extends 9 to $10 \mathrm{~km}$ southwest (units bmb, bsi). Comparably extensive lava flows issued from more modest cones or fissures to produce units bcr, bgs, bnb, bnf, and bns. At an elevation of 1,585 $\mathrm{m}(5,200 \mathrm{ft})$, Potato Butte is regionally conspicuous atop the Simcoe Mountains Anticline, but, even though its lava flows (unit bpb) drape both limbs, its eruptive volume is small $\left(\sim 0.2 \mathrm{~km}^{3}\right)$. The Hagerty Butte center (unit bhb) consists of a double scoria cone in the middle of a shield $\sim 5 \mathrm{~km}$ across, and its flows spread more equantly than on most shields here; the larger scoria cone, $130 \mathrm{~m}$ high, was once the site of a fire lookout. Compositionally unique in the Simcoe Mountains volcanic field is a pair of aphyric trachytes-Dome 3649 (unit tvs), just south of Vessey Springs, and part of Cone 3963 (unit t39), $2 \mathrm{~km}$ east of the springs. No rhyolites are exposed in this swath or farther west.

Few vent alignments that might express the regional stress field are apparent. Fissure vents for units bnb and $\mathbf{b} 85$ trend north, but several others do not. There are also a few units fed by scoria-cone pairs (bgs, bhb, bnb, bns, byc), but only the paired cones of units bnb and byc are arranged north-south. Overall, the 58 vents exposed within the central swath appear to be randomly scattered.

Although there are a few older lava flows here, the oldest units radioisotopically dated in the central swath to date are McKays Butte (unit bmb; 2,079 $\pm 5 \mathrm{ka}$ ) and the basalt of Olney Creek (unit boc; $2,136 \pm 5 \mathrm{ka}$ ), which may have erupted from a vent north of Toppenish Creek. Several units have been dated in the range 1,700 to $1,300 \mathrm{ka}$. The youngest units in this central swath (bbc, bfc, bkb, bpb, bps, and b58) lie along the Simcoe Mountains Anticline; in the age range $822 \pm 3$ ka to $631 \pm 27 \mathrm{ka}$, these six units erupted during an interval shared by many scoria cones and their lava flows on the south limb of the anticline (0.9-0.6 Ma; Uto and others, 1991) and as far south in the southern segment as Haystack and Lorena Buttes (fig. 1).

\section{Swath of Lesser Vent Density}

The swath of lesser vent density (fig. 5), which is $8-9 \mathrm{~km}$ wide and stretches $\sim 24 \mathrm{~km}$ north-south, is drained by Brush, Tepee, Blue, Schafer, Summit, and White Creeks (fig. 3). The adjacent strip mapped just north of the northern anticline (Mike Coon Hillside) is drained by Toppenish Creek. Altogether, 22 vents are recognized in the swath, 17 more are inferred to be buried, and several northern lava flows came from vents north of the map area. Three vents (for units b01, b32, a72) are on the south slope of the northern anticline, and one (for unit msp) lies north of it. Within this swath, the southern (Simcoe Mountains-Grayback Mountain) anticline carries no vents, although two on its southern limb are not far south of the map area. The swath is marked by many small scoria/spatter cones with modest lava-flow aprons, and the only substantial shields are those of Poland Butte and Twin Buttes, each only 3 to $4 \mathrm{~km}$ across.

The oldest dated flows in this swath are phenocryst-poor basalts near the southeast rim of White Creek, where they rest on CRBG lavas that form the canyon walls below; four different units here (bcl, bsh, bsp, and btb) gave ages from 3,250 to 3,300 ka. Unit a72, which erupted on the anticline near the north end of the swath, also gave an age in this range. Farther north along the White Creek rim, near Cedar Valley Road and opposite the toe of Oak Hill Shield, another shield-forming aphyric basalt (unit bw), stratigraphically the oldest Simcoe lava in its local area, gave an age of $1,885 \pm 5 \mathrm{ka}$. The stratigraphically youngest

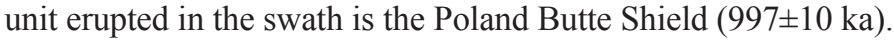
Several extensive lava-flow aprons (units bbl, bcv, bcr, bnb, bns, and bsc; all 1,700-1,300 ka) enter the swath from vents farther east, in the central swath.

\section{Western Swath}

The western swath (fig. 5) extends $\sim 14 \mathrm{~km}$ westward from uppermost White Creek to the Klickitat River and stretches $\sim 23$ $\mathrm{km}$ north-south from anticline to anticline. The area is drained eastward into White Creek and southwestward into Surveyors, Pole, Trout, Deer, Bear, and Elk Creeks (fig. 3), which all join the Klickitat. The Signal Peak Shield is centered $3 \mathrm{~km}$ north of 
the northern anticline (Peavine Ridge), and the map area further includes several basaltic lava flows that advanced south from the large Lincoln Plateau Shield, centered $4 \mathrm{~km}$ north of Signal Peak (in the northern segment). At the southwest corner of the map where White Creek converges with the Klickitat, vents for the Wellenbrock Spring Shield (unit bwb) lie just $1.5 \mathrm{~km}$ south of the map edge. West of the Klickitat River in the adjacent Glenwood area (mapped by Hildreth and Fierstein, 1995), Simcoe-age lava flows are represented by one small shield and distal aprons of six mafic units, the vents of which are covered by middle and late Pleistocene flows of the Mount Adams volcanic field.

Altogether, the western swath has 29 exposed vents, of which only two lie west of the Klickitat. Additionally, there are 18 distinctive units of Simcoe ages produced by vents now buried, including the six in the Glenwood area. Many of the vents are mafic shields of modest extent, with or without capping scoria cones. Broadest are the 9-km-wide Oak Hill Shield (unit boh; $981 \pm 14 \mathrm{ka}$ ) of phenocryst-poor olivine basalt, the 6-km-wide Jungle Butte Shield (unit bjb) of olivine-rich basalt dated at 1,350 $\pm 50 \mathrm{ka}$, and the 8-km-wide Wellenbrock Spring Shield (unit bwb; 3,440 $\pm 70 \mathrm{ka}$ ), also of olivine-rich basalt. Most imposing is the steep 1,550-m (5,100-ft) Signal Peak Shield (unit msk; 3,684 $\pm 49 \mathrm{ka}$ ) that, having $500 \mathrm{~m}$ of relief, is the outstanding fire-lookout location in the volcanic field. Aphyric basaltic unit bpc $(3,320 \pm 7 \mathrm{ka})$ crops out from the east side of Jungle Butte for $15 \mathrm{~km}$ southeastward as far as White Creek but is extensively covered by younger flows; although its vent is probably now buried beneath Jungle Butte, it may once have been the largest shield in the western belt. Two medium-sized shields lie near the west rim of White Creek: Klose Butte caps a 5-km-wide apron of aphyric basaltic flows (unit bkl; 1,740 $\pm 2 \mathrm{ka}$ ), and scoria Cone 3442 caps the Shamrock Spring Shield (unit bsr; 1,685 $\pm 11 \mathrm{ka}$ ), which fed a plagioclase-rich lava tongue $8 \mathrm{~km}$ long. Two more small shields face each other across the Klickitat River: Shield 2368, only $3 \mathrm{~km}$ wide, lies at the southeast edge of Jungle Butte and consists of phenocryst-poor basalt (unit b68); Shield 2971, 3 to $5 \mathrm{~km}$ across, lies just west of the map area, across the Klickitat River opposite Jungle Butte, and consists of similarly crystalpoor mafic lavas dated at $903 \pm 13 \mathrm{ka}$ (unit abc of Hildreth and Lanphere, 1994). The six mafic units in the Glenwood area (all vent-covered orphans) are either dated or bracketed by enclosing units to have erupted in the interval 1,000-900 ka (Hildreth and Fierstein, 1995), before being partly overrun by much younger lava flows of Mount Adams and the King Mountain Shield.

In addition to the shields, the western swath further includes several scattered scoria/spatter cones and a north-south chain of cones and fissures that built the divide between White and Pole Creeks. A vent cluster north of Oak Hill includes units bly and b29, which respectively yielded ages of $1,677 \pm 4 \mathrm{ka}$ and $1,420 \pm 4 \mathrm{ka}$. One of the most remarkable eruptive units in the volcanic field is the diktytaxitic low-K tholeiitic basalt of Outlet Falls (unit bof), an accumulation of hundreds of thin lava flows, altogether as thick as $150 \mathrm{~m}$ locally, that is preserved as steep sidewalls, adjacent plateaus, and cliffside remnants along the Klickitat River gorge for $\sim 35 \mathrm{~km}$ downstream from near Jungle Butte (from River Mile 51.5 to 30). Unit bof is among the most voluminous eruptive units in the volcanic field, and its flows backfilled up the White Creek tributary for $4 \mathrm{~km}$ at Schafer Pocket. Along the canyon walls, the base of the unit is widely exposed atop the CRBG, but for an 8-km-long reach it also floors the Klickitat River gorge. Although relatively young ( $967 \pm 4 \mathrm{ka}$ ), its source vent is unknown, buried by either Mount Adams or Pleistocene basalts, west of the Klickitat. Similar but older low-K tholeiitic lava flows crop out in a few other areas nearby; near Elk Creek, diktytaxitic unit brr underlies widespread unit bpc $(3,320 \pm 7 \mathrm{ka})$, and on the walls of White and Brush Creek canyons, southeast of Klose Butte, remnants of diktytaxitic unit bsk appear to be sandwiched by flows of unit bpc.

To summarize, the five swaths of the central segment (fig. 5) altogether contain about 135 exposed vents. This number can be compared with $\sim 20$ recognized vents in the northern segment and $\sim 50$ in the southern. In the central segment, we also mapped $\sim 70$ distinguishable units for which vents have been buried by younger units; the majority of these demand vents separate from those of the lava flows that cover them. For the Simcoe Mountains volcanic field as a whole, therefore, 205 vents are recognized, and at least a third more are likely but unexposed.

The stratigraphic and radioisotopic ages provide little suggestion of any systematic distribution or spatial progression of eruptive activity with time in the central segment. This generality may not apply, however, to the northern and southern segments. Ongoing work in the northern segment suggests that most of it is older than $3 \mathrm{Ma}$. Unpublished dating of numerous units in the southern segment (K. Uto, written commun., 2012) indicates that most of the scoria cones south of the highland shield are younger than $1 \mathrm{Ma}$. Within the central segment, the highland shield complex was especially productive in the early interval 4.0 to $3.4 \mathrm{Ma}$, but it also provided one of the youngest centers - the Tadpole Lake Shield $(790 \pm 18 \mathrm{ka})$. Moreover, within the map area, the northeasternmost vents (units bbw, btw; $3,325 \pm 45 \mathrm{ka}$ ), the southwesternmost vent (unit bwb; $3,440 \pm 70 \mathrm{ka}$ ), and the northwesternmost vent (unit msk; $3,684 \pm 49 \mathrm{ka}$ ) all erupted relatively early in development of the volcanic field. Vents younger than $\sim 1$ Ma dominate the southcentral boundary area of the segment but are also present at Oak Hill, Poland Butte, and Tadpole Lake. Eruptive units in the intermediate age range, from 2.2 to $1.2 \mathrm{Ma}$, are abundant and widely scattered across the central segment.

The radioisotopic ages determined do, however, indicate an apparent lack of eruptive activity between 3.2 and 2.2 Ma. Dated and age-bracketed units are numerous and widespread in the intervals 4.0 to $3.2 \mathrm{Ma}, 2.2$ to $1.2 \mathrm{Ma}$, and 1.0 to $0.6 \mathrm{Ma}$, but none have been identified that erupted during the millionyear-long interval 3.2 to $2.2 \mathrm{Ma}$, which straddles the PliocenePleistocene boundary. Further dating might well identify units within this gap, but because we emphasized dating the principal units in all sectors, their number and volume would inevitably be small.

Other than the reverse faults at hinges of north-vergent anticlines in the CRBG (Bentley and others, 1980; Anderson, 
1987a; not mapped by us), there are few faults in the volcanic field. The three mapped at Summit Creek, Lakebeds, and Telephone Canyon are all nearly vertical, strike northnorthwest, and appear to be cross-faults of minor normal and dextral displacement that accommodate bends in the Simcoe Mountains anticlinal axis. Exposure is inadequate to quantify fault displacement of Simcoe units, but it appears to be no greater than a few tens of meters. Farther east and west, many more such anticline-crossing faults of small displacement cut the CRBG (Bentley and others, 1980; Walsh and others, 1987), but they do not affect Simcoe lava flows.

Although growth of the anticlines that fold the CRBG began as early as $16 \mathrm{Ma}$ during accumulation of the Grande Ronde Basalt (Reidel, 1984; Reidel and others, 1989, 1994), uplift of the anticlines in the map area evidently continued during and after Pliocene and early Pleistocene emplacement of some of the Simcoe units. Along the south limb of Peavine Ridge Anticline, lavas of units b97, bpr, bsr (1,685 $\pm 11 \mathrm{ka})$, btn, and bwk have been warped up higher than their vents, some only slightly and others by as much as $80 \mathrm{~m}$. On the north limb of Peavine Ridge, parts of unit bjs (older than 3.6 Ma) appear to have been elevated modestly. On the south limb of the Mike Coon Hillside Anticline, lavas of unit b01 have been elevated $\sim 30 \mathrm{~m}$ above their vent; on the north limb, the margin of unit bwh was raised as much as $80 \mathrm{~m}$. Against the north limb of Toppenish Ridge Anticline, the south edge of the lava plateau of unit boc $(2,136 \pm 5 \mathrm{ka})$ has been upwarped by at least $100 \mathrm{~m}$ and the underlying unit bdl by $\sim 150 \mathrm{~m}$. Several other lava flows appear to have banked against or flowed along the toe of the anticlines without detectable deformation. To the south, the Simcoe Mountains Anticline is topped by several vents and is draped by their flows. For most such units, deformation is not obvious, but, on the north limb, the southern parts of units b52 and b59 appear to have been elevated slightly above their vents, and the south edge of the unit $\mathbf{m s r}$ outlier south of Satus Creek was upwarped by at least $30 \mathrm{~m}$. Evidence has been mapped elsewhere in the Yakima Foldbelt for continuing or renewed fault displacement on the north limbs of the Toppenish Ridge and Saddle Mountains Anticlines, even during the Holocene (Campbell and Bentley, 1981; West and others, 1996).

No moraines or other evidence of glaciation have been found in the central or southern segments of the Simcoe Mountains volcanic field. This is not surprising, because the highlands reach elevations of only 1,700 to $1,775 \mathrm{~m}$ and lie 40-50 km inland from the Cascade crest at 3,742-m-high Mount Adams. However, the 100-m-high steep northeast face of Cone 5822 (unit b58), which rises above the marsh-filled fault trough at Lakebeds, is likely to have been modified by ice. Likewise, excavation of the headwaters bowl of Satus Creek canyon, rimmed at 1,700 m elevation by steep walls $200 \mathrm{~m}$ high, may have been enhanced by nivation and ice-slope erosion. The floor of the bowl is filled by thick colluvium, but we detected no moraine or protalus rampart. One might envisage on both escarpments cornice-fed ice slopes, long-lived enough to pluck and steepen them but never voluminous enough to advance significantly as a valley glacier. Lava flows rimming the bowl (unit b59) are $4 \mathrm{Ma}$, and Cone 5822 is $700 \mathrm{ka}$, so congelifraction and cirque-like erosion could have taken place in the early or middle Pleistocene.

Because most of the Simcoe Mountains volcanic field is older than $1 \mathrm{Ma}$, and because it lies contiguously inland from the recurrently glaciated highlands around Mount Adams and Goat Rocks, most Simcoe surfaces of low or moderate relief have accumulated 1 to $5 \mathrm{~m}$ of Pleistocene loess. The loess, in turn, is covered and stabilized by well-developed forest soils. As a result, exposure is poor except along canyons, and rubbly colluvium with spheroidally weathered corestones is usually the best one finds. Owing to the general lack of glaciation and the limited erosion of upland surfaces, however, the colluvium typically reflects the flow concealed below-a boon to geologic mapping.

\section{Northern Segment}

We have reconnoitered the northern part of the volcanic field, but detailed geologic mapping remains incomplete. The northern segment differs from the central and southern in exhibiting rather few exposed vents, no more than 20 , which produced extensive plateau-capping lava flows, predominantly basaltic. Several deep canyons are incised through the Simcoe units, widely exposing contacts where the middle Miocene flows of the CRBG bank against Oligocene and Miocene rocks of the ancestral Cascades volcanic arc (Walsh and others, 1987), an assemblage not elsewhere exposed in the Simcoe Mountains volcanic field.

North of the Peavine Ridge Anticline, the northern segment of the volcanic field is areally the smallest and has been deeply dissected by canyons cut into pre-Pliocene rocks (fig. 1). Within the map area are the steep Signal Peak Shield (unit msk) and several plateau-forming mafic units that rim both sides of Toppenish Creek. North of the map edge, a $105-\mathrm{km}^{2}$ plateau of basaltic lava flows extends an additional $10 \mathrm{~km}$ northward, ending at the canyon rims of Piscoe Creek and the Klickitat River and including the broad basaltic shields of Lincoln Plateau (unit blp), Bullgrouse Ridge, and Panther Butte, as well as flows from seven lesser vents (fig. 5).

North of the Piscoe-Klickitat confluence are a few outliers of Simcoe-age flows, as depicted on the state geologic map (Walsh and others, 1987) and on figure 1. Largest of these is a $100-\mathrm{km}^{2}$ south-sloping plateau that extends from Jennies Butte to Windy Point, holds the many forks of McCreedy Creek, and includes the basaltic shields of Holdaway Meadow and Johns Butte, as well as the dacite cone called Jennies Butte. An $8-\mathrm{km}^{2}$ basaltic plateau remnant caps the Piscoe Creek-Diamond Fork divide, and another $\left(\sim 14 \mathrm{~km}^{2}\right)$ caps Fairview Ridge, which separates the Diamond Fork from the upper Klickitat River canyon. A fourth remnant $\left(\sim 7 \mathrm{~km}^{2}\right)$ consists of a small asymmetrical shield on the divide between Diamond Fork and Cultus Hole, and a $14-\mathrm{km}^{2}$ remnant (of uncertain affinity) caps the Klickton Divide northeast of Spencer Point, where the intraplate Simcoe field adjoins and overlaps with the contemporaneous Goat Rocks arc-volcanic cluster (figs. 1, 2). 


\section{Southern Segment}

The southern segment, $\sim 25 \mathrm{~km}$ wide (east to west) and covering $\sim 460 \mathrm{~km}^{2}$, extends $\sim 20 \mathrm{~km}$ southward from the crest of the Simcoe Mountains Anticline to the Little Klickitat River (fig. 1). Unlike the central and northern segments, it lies outside the Yakama Reservation, the south boundary of which closely follows the anticlinal crest. Broad outlines of the segment are depicted on reconnaissance maps (Sheppard, 1967a; Anderson, 1987b; Walsh and others, 1987), which also indicate many of its $\sim 45$ scoria cones, but detailed mapping of its complexly shingled field of lava flows has yet to be completed. Such mapping was initiated (Uto and others, 1991), and, during preliminary work, $\sim 35$ samples were K-Ar dated at the USGS in Menlo Park, California, and a much larger suite chemically analyzed.

In simplified terms, the southern segment consists of two assemblages: a Pliocene shield-like edifice, the apron flows of which cover virtually the whole segment, and a superimposed field of $\sim 25$ younger scoria cones and derivative lava flows. The asymmetrical shield-like edifice was principally supplied by a vent cluster around Indian Rock but also by $\sim 20$ scoria cones widely distributed across its middle and lower slopes. Because the Indian Rock cluster and the other vents all lie south of the anticlinal crest, lava flowed only southward. The edifice they produced is thus spatially separate from shield flows north of the anticlinal crest that were fed from vents around Castle Rock and Lakebeds. The high anticlinal ridge of the Miocene CRBG separates the vent clusters and all but a few of their derivative flows. Both of the multi-vent shields, although predominantly basaltic, are cored by thick masses of rhyolite and minor dacite. Moreover, they are approximately contemporaneous; shield basalts and rhyolite south of the divide yield ages of 4.2 to 3.4 Ma (Uto and others, 1991; Phillips and others, 1986), and those north of the divide yield 4.0 to $3.4 \mathrm{Ma}$ (table 1 ).

The distributed field of post-shield scoria cones is scattered largely in the western half of the southern segment but includes outliers at Haystack Butte (fig. 1; $15 \mathrm{~km}$ south, atop the Columbia Hills Anticline [fig. 4]) and the Lorena Butte alignment a few kilometers southeast of Goldendale. Most give $\mathrm{K}$-Ar ages in the range 900-600 ka, but a few are close to 2 Ma (Uto and others, 1991). Radioisotopic ages now in hand thus suggest a few widely separated eruptive episodes in the southern segment, similar to the three episodes (4.0-3.2 Ma; 2.2-1.2 Ma; and 1.0-0.6 Ma) inferred for the central segment, which contains three times as many vents.

Products of the southern Simcoe Shield are both alkaline and tholeiitic, not calcalkaline; they contain varied abundances and proportions of plagioclase, olivine, pyroxenes, and spinel and many carry nodules of spinel lherzolite, harzburgite, or dunite, and xenocrysts disaggregated therefrom. Rhyolites are phenocryst poor, and the sparse dacites are plagioclaserich hybrids that carry disequilibrium assemblages of mixed phenocrysts. All of the younger mafic scoria cones are alkaline and, although most are phenocryst poor, they contain sparse amounts of the same phenocryst species as present in shield lava flows, as well as varied cargoes of peridotite nodules and their derivative xenocrysts. Shield tholeiites range continuously from 48 percent to 56 percent $\mathrm{SiO}_{2}$ and alkaline products of the shield stage from 46.5 percent to 50.5 percent. The younger suite of distributed cone-fed alkali basalts ranges continuously from 46 percent to 50.5 percent $\mathrm{SiO}_{2}$. All products analyzed, whether alkaline or subalkaline, are strongly enriched in Ti and $\mathrm{Nb}$ relative to arc basalts of the adjacent Cascades.

Eruptive volumes estimated for the southern segment are $\sim 35 \mathrm{~km}^{3}$ for the shield stage and $\sim 5 \mathrm{~km}^{3}$ for the younger distributed scoria-cone stage. Flows of both stages rest principally upon folded middle Miocene Wanapum Basalt or, very locally, on intercalated Ellensburg Formation gravels or underlying windows of Grande Ronde Basalt (Anderson, 1987a, b; Walsh and others, 1987).

\section{Composition of Eruptive Products}

Compositions of 1,300 samples from the central segment are plotted against $\mathrm{SiO}_{2}$ in figures 6-9. The suite is not calcalkaline, in contrast to most eruptive suites in the nearby Cascade Arc. On the conventional $\mathrm{FeO} * / \mathrm{MgO}$ versus $\mathrm{SiO}_{2}$ diagram (fig. 6), all but a handful of samples (principally units bwb, mrw, msg, and $\mathbf{m s l}$ ) plot in the tholeiitic field, and most plot in the high-Fe field of Arculus (2003). Most samples are high-K, and one third are medium-K (fig. 7). The few samples that plot in the low-K field belong to units bof, brr, bsa, bsk, and btr, diktytaxitic low-potassium olivine tholeiites with 16.3 to 18.0 percent $\mathrm{Al}_{2} \mathrm{O}_{3}$. The alkali-lime index, as defined by Peacock (1931), where $\mathrm{CaO}$ and $\mathrm{Na}_{2} \mathrm{O}+\mathrm{K}_{2} \mathrm{O}$ trends intersect (not shown), yields two separate values - a dominant alkalic suite intersecting at $\sim 50$ percent $\mathrm{SiO}_{2}$ and a secondary calcalkalic suite intersecting at $\sim 58$ percent.

On the total alkali-silica (TAS) diagram of LeBas and others (1986), $>80$ percent of the 1,300 samples are alkaline and $\sim 20$ percent subalkaline (fig. 8). As there are no picrobasaltic, basanitic, or phonolitic rocks, the Simcoe alkaline assemblage is only moderately alkaline. About a third of the nominally alkaline basalts have normative nepheline in their calculated CIPW norms, while the rest are transitional, having abundant normative olivine and minor normative hypersthene. Basalts and trachybasalts make up $\sim 86$ percent of the rocks analyzed; 11 percent are alkaline or subalkaline intermediates, 2 percent are rhyolites, and $<1$ percent are trachytes or trachydacites. The $\sim 40$ subalkaline intermediate samples principally represent map units mcc, mkc, msc, msk, and $\mathbf{m t w}$. Within the trachybasalt field, consideration of relative contents of $\mathrm{Na}_{2} \mathrm{O}$ and $\mathrm{K}_{2} \mathrm{O}$ (LeBas and others, 1986) yields a continuum of hawaiites (sodic) and potassic trachybasalts, both abundant. The more evolved alkalic intermediate fields (basaltic trachyandesite and trachyandesite) display two or three arrays differently enriched in alkalies (fig. 8). The differences do not, however, reflect relative contents of $\mathrm{Na}_{2} \mathrm{O}$ and $\mathrm{K}_{2} \mathrm{O}$, as most samples along each array in these fields are mildly potassic; only the slightly more sodic units $\mathbf{m t c}$ and $\mathbf{m v s}$ are transitional to mugearite and unit aec to benmoreite. None of the trachytes and rhyolites are peralkaline.

Trace element patterns (fig. 9) for the predominantly alkalic Simcoe rocks have characteristically intraplate 


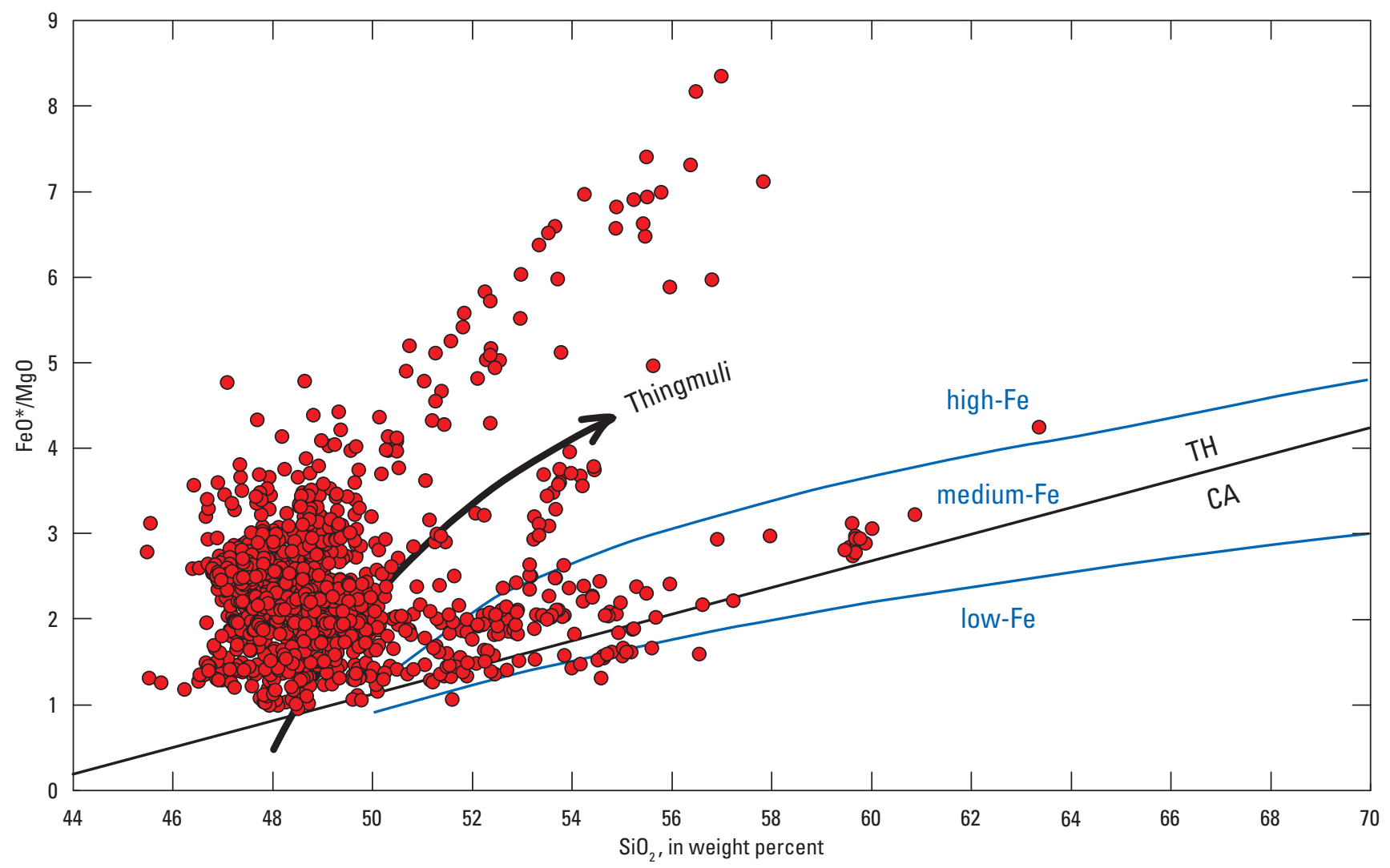

Figure 6. $\mathrm{Fe} 0 * / \mathrm{MgO}$ versus weight percent $\mathrm{SiO}_{2}$ for $\sim 1,250$ samples from central segment of Simcoe Mountains volcanic field. Rhyolite and trachytes are omitted, off scale at very high $\mathrm{Fe} 0 * / \mathrm{MgO}$. TH/CA line separates tholeiitic and calcalkaline fields as defined by Miyashiro (1974). High-, medium-, and low-Fe fields follow Arculus (2003). Thingmuli trend is that of Carmichael (1964). $\mathrm{Fe} 0 *$ represents total iron content calculated as $\mathrm{FeO}$.

signatures (Leeman and others, 1990), much like those conventionally compared to ocean-island basalts (OIB) and widely interpreted to originate by decompression partial melting of convecting (asthenospheric) mantle, with little or no contribution from a subducting slab. Exceptions are a few low-K tholeiitic units (bof, brr, bsa, bsk, btr), which have MORB-like patterns, and some westerly units that erupted on or near Mount Adams, which have arc-type patterns deficient in $\mathrm{Nb}$ and $\mathrm{Ta}$.

The mafic alkalic intraplate compositional character (fig. $9)$ is represented by elevated $\mathrm{Nb}(20-80 \mathrm{ppm})$ and $\mathrm{Zr}(200-500$ $\mathrm{ppm})$ and by low $\mathrm{Ba} / \mathrm{Nb}(6-25)$. Ba concentration ranges widely (300-1,000 ppm), as do the ratios $\mathrm{Ba} / \mathrm{Zr}(1-3.5)$ and $\mathrm{Zr} / \mathrm{Nb}$ (4.5-17). $\mathrm{TiO}_{2}$ contents are 1.8 to 3.0 percent in rocks with $>7$ percent $\mathrm{MgO}$ and 3 to 4 percent in rocks with 7 to 4 percent $\mathrm{MgO}$. Likewise, $\mathrm{P}_{2} \mathrm{O}_{5}$ concentrations are 0.4 to 0.7 percent in basalts with $>7$ percent $\mathrm{MgO}$ and 0.4 to 2.3 percent in those with 7 to 4 percent $\mathrm{MgO}$. Abundances are far lower, of course, in the low-K tholeiites: $\mathrm{Nb}(3-16 \mathrm{ppm}), \mathrm{Zr}(75-135$ ppm), $\mathrm{Ba}(50-125 \mathrm{ppm}), \mathrm{TiO}_{2}(1.2-1.8 \%)$, and $\mathrm{P}_{2} \mathrm{O}_{5}(<0.25 \%)$. The few isotopic determinations published for Simcoe rocks are consistent with non-arc asthenospheric sources: ${ }^{87} \mathrm{Sr} /{ }^{86} \mathrm{Sr}=$ $0.70287-0.70316$ and ${ }^{143} \mathrm{Nd} /{ }^{144} \mathrm{Nd}=0.51287-0.51300$ (Leeman and others, 1990; Bacon and others, 1997). Wide ranges of $\mathrm{Zr} /$ $\mathrm{Nb}$ ratios among the mafic alkalic rocks (4.5-17) and the low-K tholeiites (8-20) suggest that the parental magmas of both suites represented considerable ranges of partial-melt fraction when separated from mantle sources.

In contrast to the Cascade Arc of Washington and Oregon, where primitive basalts (other than low-K tholeiites) are sparse (Bacon and others, 1997; Hildreth, 2007), a significant fraction of Simcoe basalts is fairly primitive in retaining high contents of $\mathrm{Mg}, \mathrm{Cr}$, and $\mathrm{Ni}$. Of the 223 units described, 185 are basaltic. Among the basaltic units, 56 include samples having $>7$ percent $\mathrm{MgO}$, and 21 of those include samples with $>9$ percent $\mathrm{MgO}$. Among the 56 units are 22 that are phenocryst-poor, 16 that are crystal-rich, and 18 of intermediate (5-12\%) crystal content. The 21 high-Mg units include 7 that are phenocryst-poor, 6 that are moderately porphyritic, and 8 that carry $5-15$ percent olivine. Most samples with $>7$ percent $\mathrm{MgO}$ also contain 100-250 ppm $\mathrm{Ni}$ and 200-400 ppm Cr, and a dozen or so have 250-430 Ni and 400-750 Cr. Owing principally to separation of olivine (with spinel inclusions) and clinopyroxene crystals, most samples with $<5$ percent $\mathrm{MgO}$ contain $<70 \mathrm{ppm} \mathrm{Ni}$ and $<100 \mathrm{ppm} \mathrm{Cr}$.

Many map units are chemically heterogeneous. Some of the variation is attributable to inhomogeneously distributed cargoes of non-phenocrystic crystals - megacrysts and fragments thereof, gabbroic cumulates and derivative antecrysts, and peridotitic xenoliths and constituent crystals liberated from them. Of the 223 volcanic map units described for the central segment, 83 mafic units have moderate or high contents of crystals. Among the 70 of these units from which several samples have been 


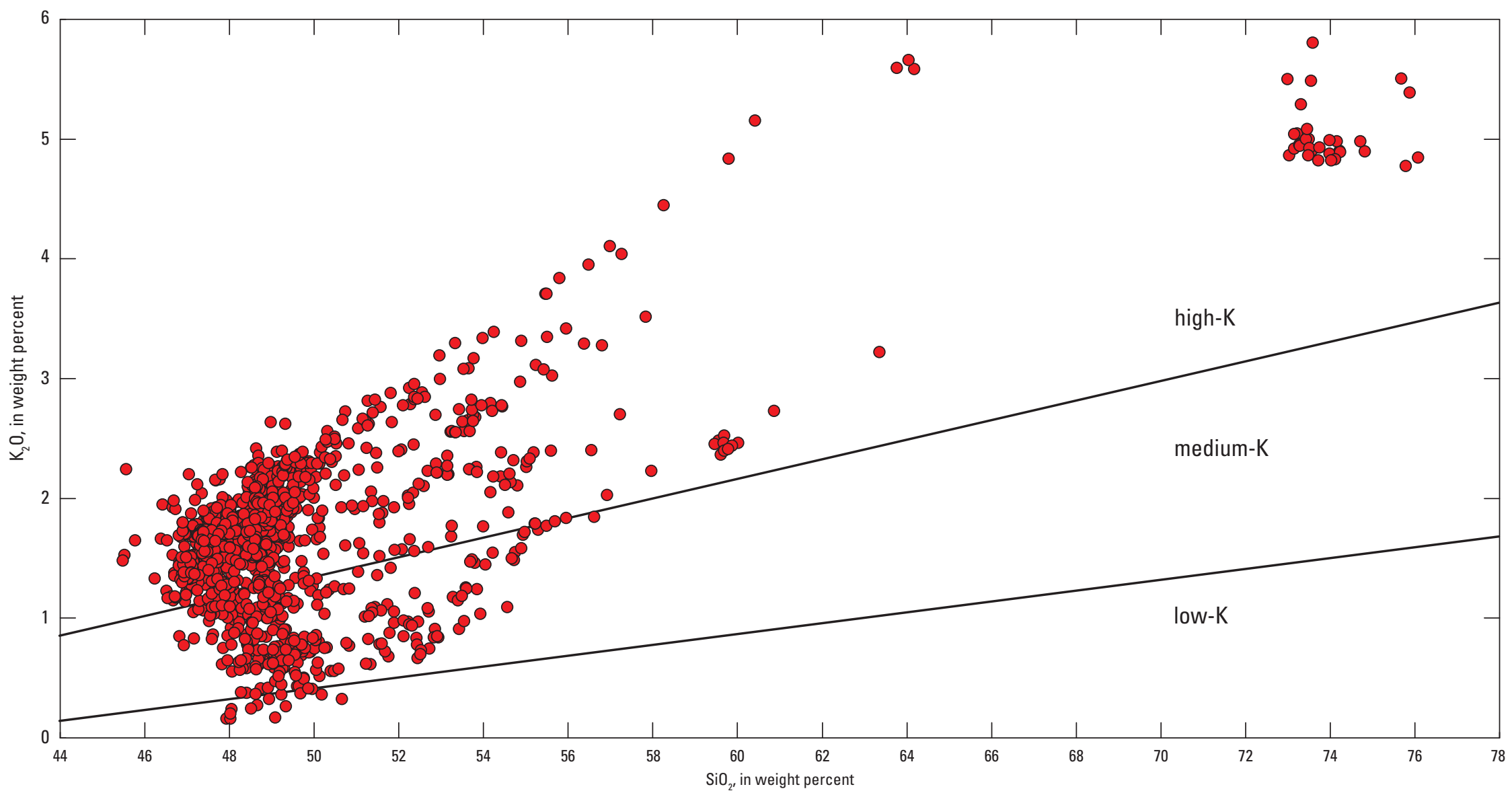

Figure 7. $\mathrm{K}_{2} \mathrm{O}$ versus $\mathrm{Si}_{2}$, both in weight percent, for $\sim 1,300$ samples from central segment of Simcoe Mountains volcanic field. High-, medium-, and low- $\mathrm{K}$ fields are extended from Gill (1981). 


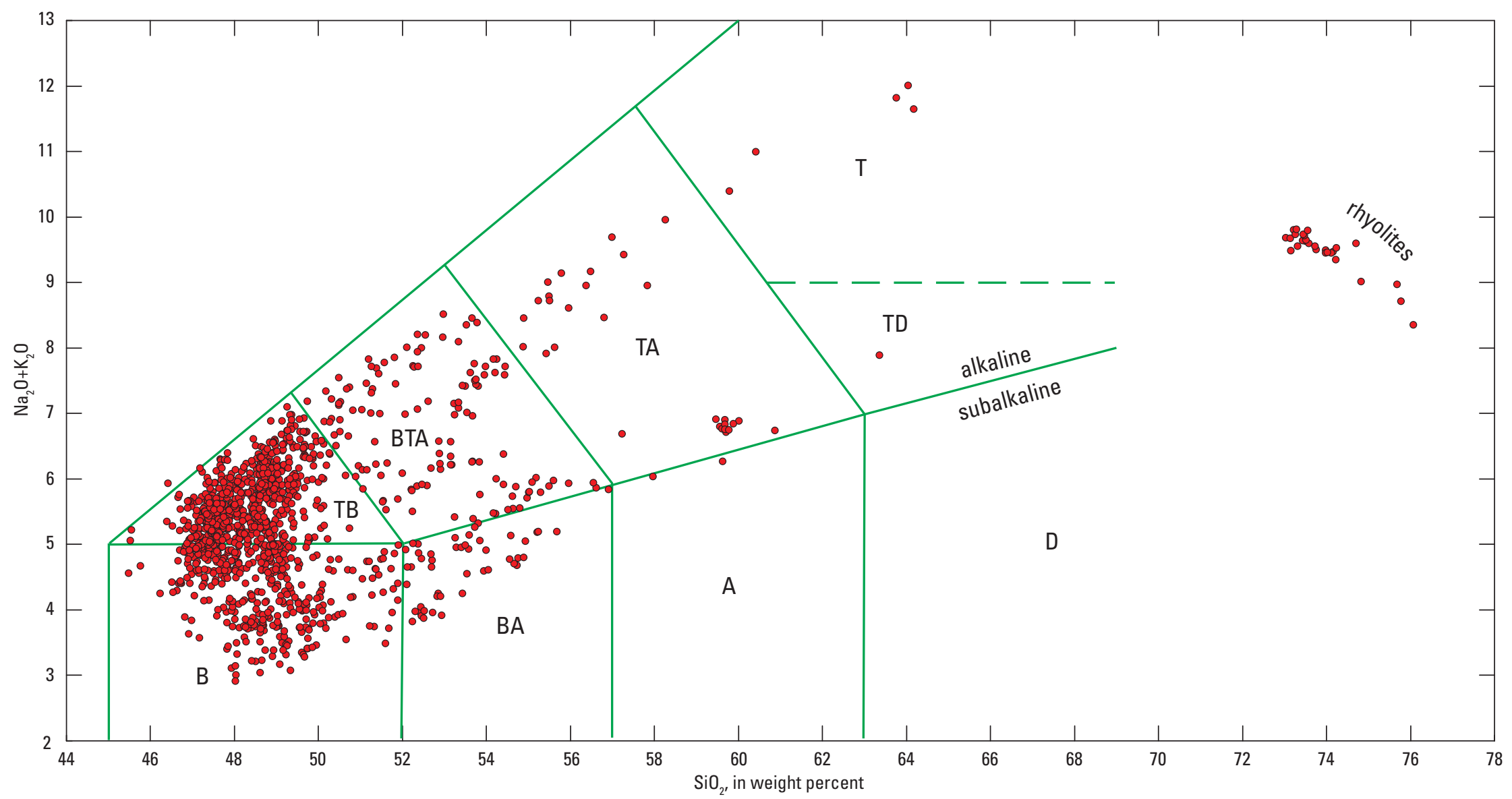

Figure 8. Total alkalies versus silica (TAS) diagram of LeBas and others (1986), showing conventional chemical pigeon-holing of volcanic rock names for $~ 1,300$ samples from central segment of Simcoe Mountains volcanic field. A, andesite; B, basalt; BA, basaltic andesite; BTA, basaltic trachyandesite; D, dacite; T, trachyte; TA, trachyandesite; TB, trachybasalt; TD, trachydacite. 

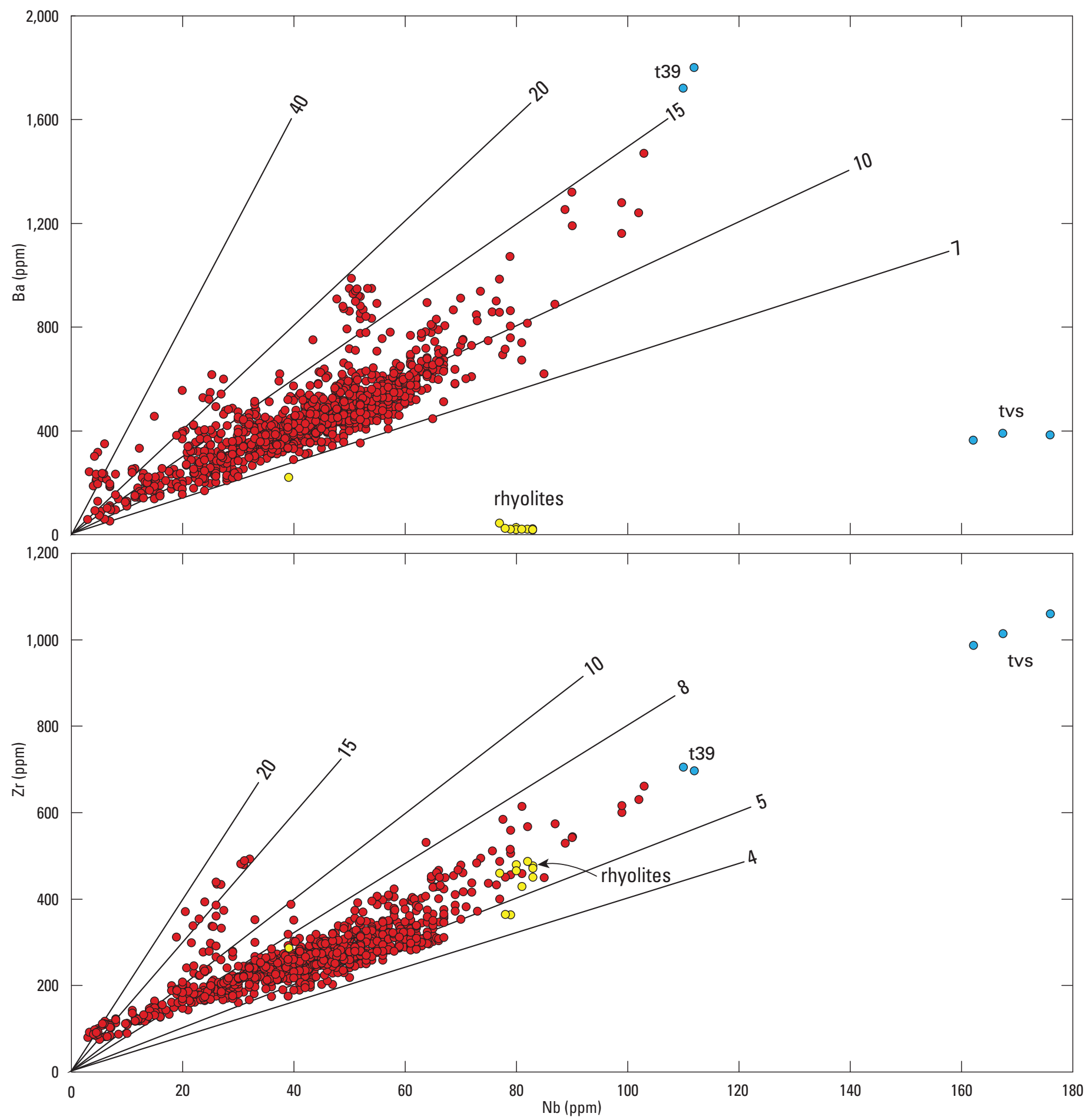

Figure 9. Ba and Zr versus $\mathrm{Nb}$, all in ppm, for $\sim 1,250$ samples from central segment of Simcoe Mountains volcanic field. Diagonal lines indicate ratios of element pairs. Rhyolite cluster and two trachyte units $(\mathbf{t} 39, \mathbf{t v s})$ are labelled. 
chemically analyzed, the ranges of heterogeneity are $\leq 1$ percent $\mathrm{SiO}_{2}$ for 34, 1-2 percent $\mathrm{SiO}_{2}$ for 25, 2-3 percent for only 5, and $>3$ percent for 6 units. The six most heterogeneous of the porphyritic map units are aec, bld, bwc, b59, mrw, and msl, among which all but unit bwc are crystal-rich flows of the Castle Rock Shield. Within each of the six, amounts and proportions of clinopyroxene, olivine, and plagioclase phenocrysts and megacrysts range considerably, accompanied by varied cargoes of relatively mafic blebs and enclaves, gabbroic clots and fragments, and partially melted silicic xenoliths and derivative xenocrysts. Unit bwc is a package of lava flows with varied phenocryst proportions that includes at least one flow enriched in plagioclase cumulate mush.

On the other hand, of the 223 volcanic map units described, 104 mafic units are aphyric or nearly so, along with all but one rhyolitic unit and both trachytes. Most of the aphyric mafic units consist predominantly of products with 4-7 percent $\mathrm{MgO}$, but a few are packages of lava flows that include individual flows with 2.5-4.0 percent $\mathrm{MgO}$ or 7.0-9.5 percent $\mathrm{MgO}$, which we have not been able to distinguish separately in the field. Our efforts to separate and delineate aphyric mafic units have entailed a large number of chemical analyses, commonly $5-15$ for a major unit and as many as 30 or more for a few. Among the 104 aphyric mafic units, compositional ranges of $\leq 1$ percent $\mathrm{SiO}_{2}$ have been determined for 57 . The ranges are 1 to 2 percent $\mathrm{SiO}_{2}$ for 27 units; 2 to 3 percent for 17 units; and 3 to 5 percent for three units.

The processes by which packages of visually indistinguishable aphyric lava flows, presumed to have erupted in quick succession, can achieve such ranges of composition is a topic worthy of further investigation. For unit bbc (range 3.2\%), the main distinction is between more mafic apron flows and more evolved near-vent ejecta. For unit msr (range $5.6 \% \mathrm{SiO}_{2}$ ), its sprawling shield apron of many flows generally grades from phenocryst-poor proximally-medially to aphyric distally, but the extreme compositions are within stacks of lithologically similar phenocryst-poor flows. For unit $\mathbf{m x c}$ (range 5.2\%), irregular distribution of sparse phenocrysts and scattered megacrysts of plagioclase may play a role; additionally, however, the nearly aphyric flows are intercalated with thick sheets of plagioclaserich cumulate mush of unit bxc. Several other aphyric units (with far smaller compositional ranges than $\mathbf{m x c}$ ) - bcs, bsm, b97, blp, bsz, and bor - may owe some of their heterogeneity to co-evolution with magmas represented by associated lava flows rich in accumulated phenocrysts (bfr, bsm', bwk, blo, and beo). Similarly, moderately heterogeneous porphyritic units bgs and $\mathbf{m s l}$ are likewise in contact with accumulative units b36 and bcx, respectively, and units bsc and bwc each contain lenses or intercalated flows of plagioclase-rich mush. Rounded reaction-jacketed quartz crystals, typically $\leq 1 \mathrm{~mm}$, are found in units $\mathbf{m n s}$, $\mathbf{m r w}$, and $\mathbf{m s l}$, suggesting an assimilative crustal contribution to their heterogeneity.

\section{Volcano Hazards}

There has not been an eruption in the Simcoe Mountains volcanic field for 600,000 years, and there is no thermal, seismic, or other geophysical evidence to anticipate one. Nonetheless, several hundred eruptions took place here, spread recurrently over the 3.6-m.y.-long interval from 4.2 Ma until $0.6 \mathrm{Ma}$. The plate-tectonic regime is not known to have changed significantly between the Pliocene and the present, and at least weak deformation appears to be continuing in the Yakima Foldbelt. Rejuvenation of mantle melting and, consequently, renewed volcanism are not impossible. If an eruption were ever to occur here in the future, the 3.6-m.y.-long eruptive history we have documented suggests that construction of mafic scoria cones and derivative lava-flow aprons or of small mafic shield volcanoes are the probable outcomes. Road blockage by lava flows and ashfall along narrow sectors for several kilometers downwind would be the inconveniences most probable during such events. Owing to the many stream canyons in the volcanic field, any extensive lava flow is likely to enter one; any resulting basaltic dam that impounded a temporary lake would create the threat of a breakout flood, with potentially serious consequences for people and property downstream.

More likely and, in the event, more troublesome, would be an eruption of ice-capped Mount Adams, which might threaten parts of the Klickitat River drainage system with flood waters, debris flows, or (less likely) lava flows. Potential hazards from the Mount Adams area were summarized by Hildreth and Fierstein $(1995,1997)$ and Scott and others (1995).

\section{Age Relations Among Volcanic Fields in Southern Washington}

At the latitude of the Simcoe Mountains, at least 150 additional volcanic vents of Pleistocene and Holocene age, mostly scoria cones, silicic domes, and small mafic shields, are scattered for $100 \mathrm{~km}$ farther west across the Cascade Arc (Smith, 1993; Hildreth, 2007). Many more are distributed along the Cascade axis, northward as far as Bumping Lake and southward to Mount Hood and beyond (figs. 1, 4). In southern Washington, many of the vents cluster around five main fociMount St. Helens, Indian Heaven, Mount Adams, Goat Rocks, and the Simcoe Mountains volcanic field. The last mentioned, as documented here, was recurrently active from 4.2 to $0.6 \mathrm{Ma}$.

The Goat Rocks area, contiguous with the northwest end of the Simcoe field, includes a silicic complex dated at $\sim 3.2 \mathrm{Ma}$ and an andesitic stratocone cluster active in the early and middle Pleistocene. Although so far studied only in reconnaissance, the Goat Rocks arc-axis complex (Swanson and Clayton, 1983) produced voluminous eruptive products $\left(60-100 \mathrm{~km}^{3}\right)$ that were in large part contemporaneous with the alkalic intraplate activity in the adjacent Simcoe Mountains volcanic field.

South of Goat Rocks and just west of the Simcoe field, the Mount Adams volcanic field has erupted $\sim 315 \mathrm{~km}^{3}$ of Pleistocene and Holocene products, dominantly andesites, as summarized earlier. Scattered basaltic activity was underway by $\sim 940 \mathrm{ka}$, peripheral dacite eruptions began by $695 \mathrm{ka}$, and growth of the $200-\mathrm{km}^{3}$ andesitic stratocone started $\sim 520 \mathrm{ka}$, persisting into the Holocene (Hildreth and Lanphere, 1994; 
Hildreth and Fierstein, 1995, 1997). During the first 3 m.y. of Simcoe activity, there was little or no volcanism in the Mount Adams area, but subsequently (until $\sim 600 \mathrm{ka}$ ) these contiguous volcanic fields were concurrently active (albeit at low eruption rates for both) for $\sim 350,000 \mathrm{yr}$. The Mount Adams stratovolcano, however, entirely postdates cessation of Simcoe activity, whereas the Goat Rocks stratovolcanoes were contemporaneous with Simcoe activity.

The Indian Heaven volcanic field (fig. 1), centered 30 $\mathrm{km}$ southwest of Mount Adams and $\sim 50 \mathrm{~km}$ west of the Simcoe Mountains, covers about $450 \mathrm{~km}^{2}$ with 60 to $80 \mathrm{~km}^{3}$ of products erupted from $\sim 50$ vents - shields, scoria cones, and tuyas (Hammond and Korosec, 1983; Hildreth, 2007). Compositions include a wide range of alkalic, tholeiitic, and calcalkaline basalts (Leeman and others, 2005), as well as sparse andesites, but no dacites. Few reliable radioisotopic ages are available, though all units but one have been shown to be normally magnetized (Mitchell and others, 1989) and, therefore, younger than $\sim 780 \mathrm{ka}$. The youngest unit erupted $\sim 9 \mathrm{ka}$. Activity at Indian Heaven thus overlapped only the final $\sim 200,000$ years of Simcoe activity, and most of Indian Heaven is younger than Simcoe cessation.

Mount St. Helens is a predominantly dacite volcanic center in the forearc, $50 \mathrm{~km}$ west of the Cascade axis and $80 \mathrm{~km}$ west of the Simcoe Mountains. Its eruptive products are among the clearest examples in the Cascades of intracrustal melting, engendered by basaltic magmas that lodged in the crust and seldom erupted (Halliday and others, 1983; Smith and Leeman, 1987,1993 ). Since its inception $\sim 300 \mathrm{ka}$, the center has erupted $\sim 75 \pm 15 \mathrm{~km}^{3}$ of magma, most of it as lava domes and pyroclastic ejecta, in many episodes that have been most frequent since 28 ka (Mullineaux and Crandell, 1981; Mullineaux, 1996; Clynne and others, 2008). Andesite and basalt are largely limited to the young composite stratocone, which has been constructed since $2.5 \mathrm{ka}$, laced with dacite domes, and eviscerated by sector collapse in 1980 (Lipman and Mullineaux, 1981). Minor dacite dome growth resumed in 2004 (Sherrod and others, 2008). After the last Simcoe eruption $\sim 600 \mathrm{ka}$, about 300,000 years passed before inception of magmatism at Mount St. Helens.

There is thus no evidence for post-Miocene volcanism in the Cascade Arc directly west of the Simcoe Mountains volcanic field during the first $3 \mathrm{~m}$.y. or more of its activity. The Goat Rocks center to the northwest and the Boring (Portland) distributed basaltic volcanic field in the forearc far to the southwest (2.6 Ma to $\sim 57 \mathrm{ka}$; Evarts and others, 2009) were in considerable part contemporaneous with Simcoe activity. But in the broad swath of southern Washington now occupied by Mount St. Helens, Indian Heaven, and Mount Adams (and numerous lesser monogenetic volcanoes), little or no postMiocene volcanism is recognized before $\sim 1$ Ma (Smith, 1993; Evarts and Swanson, 1994; Walsh and others, 1987). Soon after Simcoe activity died out at $600 \mathrm{ka}$, growth of four longlived andesitic edifices-Mounts Hood, Adams, and Rainier and Glacier Peak - was initiated farther west, between 600 and $500 \mathrm{ka}$. Did changes take place at that time in either mantle or lithosphere dynamics that favored a westward shift in the domains of mantle magma generation along with abandonment of such domains beneath the long-lived Goat Rocks and Simcoe Mountains volcanic fields?

\section{Acknowledgments}

We are grateful to the Tribal Council of the Yakama Nation for authorization to conduct geologic mapping in the Closed Area and, back in the 1980s, at Mount Adams. Bob Pimms, Scott Ladd, and Yvonne Colfax of the Yakama Nation Water Program were instrumental in encouraging and facilitating our work here, as was Phil Rigdon of the Yakama Nation Department of Natural Resources. Ted Repasky, then also of the Water Program, got us started in the volcanic field by suggesting topical projects related to spring chemistry and geologic mapping of sites for water wells. It has been a fascinating privilege to have been offered the opportunity to investigate this volcanic field, a large natural area virtually untouched by development. Helpful reviews by Don Swanson and Russ Evarts, authorities in Washington geology, improved our presentation of the map and report.

\section{Introduction to Description of Map Units}

The geologic map portrays the central part of the Pliocene and Quaternary Simcoe Mountains volcanic field, where hundreds of eruptions took place between $\sim 4.2 \mathrm{Ma}$ and 0.6 Ma. Eruptive activity in the northern and southern parts of the field (fig. 1), though still incompletely mapped, is probably limited to the same age range. No older volcanic rocks are known to have erupted here, as the Simcoe volcanics rest directly on folded stacks of Miocene flood basalts of the Columbia River Basalt Group that issued from vents far east of here. Of 223 volcanic map units described below, fewer than half are older than $\sim 2.2$ $\mathrm{Ma}$. The oldest unit identified in the map area yields a ${ }^{40} \mathrm{Ar} /{ }^{39} \mathrm{Ar}$ age of 4,027 $\pm 61 \mathrm{ka}$, and several lava flows near Indian Rock, just south of the map area, gave K-Ar ages of 4.0 to $4.2 \mathrm{Ma}$ (Phillips and others, 1986; Uto and others, 1991).

$\mathrm{SiO}_{2}$ contents reported in the description of each volcanic unit are based on major-element analyses normalized on an anhydrous basis, determined by x-ray fluorescence methods in the U.S. Geological Survey laboratory at Lakewood, Colorado (Taggart and others, 1987), or in the Washington State University GeoAnalytical Laboratory, supervised by J.A. Wolff (http://environment.wsu.edu/facilities/geolab/service.html). Data are represented in figures 6 to 9 and are provided in appendix A at http://pubs.usgs.gov/sim/3315/.

Volcanic-rock nomenclature used here follows that of LeBas and others (1986). Basalt has 45 to 52 percent $\mathrm{SiO}_{2}$, basaltic andesite 52 to 57 percent, and andesite 57 to 63 percent. For more silicic rocks, the perennial disagreement between their scheme and standard U.S. usage does not arise, because rhyodacites are absent, and the few dacites (here, 63-64\% $\mathrm{SiO}_{2}$ ) and rhyolites $\left(73-76 \% \mathrm{SiO}_{2}\right)$ all plot well within their fields. Because most Simcoe volcanic rocks are moderately alkaline, the prefix "trachy" is applied to rock names if the total 
alkali content of a unit exceeds that of the alkaline-subalkaline boundary proposed by LeBas and others (1986). Of 223 units described below (including subunits), 83 percent are basalts $(n=185), 10$ percent are basaltic andesites $(n=21)$, and only 7 percent are more silicic (six trachyandesites, one trachydacite, two trachytes, and six rhyolites). Of the 223 units, 63 (28\%) are subalkaline, including a few low-K tholeiites. All Simcoe rhyolites are fairly alkaline $\left(9.0-9.8 \% \mathrm{Na}_{2} \mathrm{O}+\mathrm{K}_{2} \mathrm{O}\right)$, but none is peralkaline.

In unit descriptions, we abbreviate names of some common volcanic phenocrysts as follows: cpx, clinopyroxene; opx, orthopyroxene; and plag, plagioclase feldspar. Phenocrysts are defined here as $0.5 \mathrm{~mm}$ and larger; microphenocrysts (mph) as 0.1 to $0.4 \mathrm{~mm}$; and microlites smaller still. The modifier phenocryst-rich means that a rock has at least 12 percent crystals larger than $0.4 \mathrm{~mm}$; phenocryst-poor signifies $\leq 5$ percent; aphyric means none. We typically characterize rocks containing 6 to 11 percent phenocrysts as moderately porphyritic or of moderate phenocryst content. Because groundmass crystal sizes range widely within most map units, the unit descriptions give size ranges only for phenocrysts of each species, as estimated by hand lens or microscopically in thin section.

As noted in the unit descriptions, some Simcoe eruptive units carry nodules of dunite or peridotite and many more have megacrysts of plagioclase, olivine, or pyroxene. Many megacrysts are shattered or dispersed as fragments, and some are marginally resorbed. Intact megacrysts generally range in size from 5 to $30 \mathrm{~mm}$ and are visually easily distinguishable from coexisting populations of smaller euhedral phenocrysts. Many were transported as localized swarms of crystals, as if entrained from concentrations of unconsolidated cumulates, and all are considered antecrystic — produced during crystallization episodes in the deep crust or upper mantle that preceded magma evolution toward the compositions from which true phenocrysts later crystallized.

Nearly all of the 223 volcanic map units described herein are newly defined, although equivalents of a few were described by Sheppard (1967a). Each is an eruptive unit derived from a single vent or fissure. Some are simple flow units, but many are shields, cones, or stacks of several lava flows that have mineralogical, textural, and chemical coherence. Many units consist of numerous similar lava flows that are exposed only along canyon rims and are virtually never separately mappable across loesscovered low-relief surfaces. Lava-flow surface morphology is seldom preserved and rarely exposed, not even levees. Each unit was delineated by field mapping on foot and its integrity confirmed, challenged, or revised by chemical and microscopic work in the laboratory. Definition of a few units required iterative acquisition of field and lab data over a period of years, providing a firmer basis for subdividing, lumping, or correlating somewhat heterogeneous packages of flows. Most units have narrow compositional ranges, but some show zoning or heterogeneity spanning ranges of several percent $\mathrm{SiO}_{2}$. Each unit description names the contiguous eruptive units that underlie or overlie the one described, as determined by mapping in the field.

Place names cited in the text are located in figures 2 and 3. Elevations are given in feet $(1 \mathrm{ft}=0.3048 \mathrm{~m} ; 1 \mathrm{~m}=3.2808 \mathrm{ft})$ because the 1:24,000-scale topographic maps upon which the geologic map is based are available in feet only. All other measurements are metric. Grid references to site locations mentioned in the text are given to $100 \mathrm{~m}$ using the Universal Transverse Mercator (UTM) grid (1927 North American datum, zone 10), which is shown on U.S. Geological Survey topographic maps of the area. The first three digits are easting, and the second three are northing. For example, the summit of Signal Peak is approximated as 437/208 (43.7 km east, 20.8 $\mathrm{km}$ north). Occasionally, a fourth digit is added for precision to $10 \mathrm{~m}$. At the end of each unit description, the name of the U.S. Geological Survey 7.5-minute quadrangle(s) in which the map unit crops out is indicated in brackets, abbreviated as follows:

CP, Camas Patch; HB, Hagerty Butte; KC, Kusshi Creek; LCF, Logy Creek Falls; LCNE, Logy Creek NE; LCSW, Logy Creek SW; MB, McKays Butte; OF, Outlet Falls; PB, Poland Butte; SB, Stagman Butte; SP, Signal Peak; and TB, Twin Buttes (all in Washington). The geologic map is based on those 12 quadrangles (fig. 3), but reference is sometimes made to units that extend beyond the map area into adjacent 7.5-minute quadrangles, named as follows: CF, Castile Falls; DC, Dead Canyon; G, Glenwood; GB, Glaciate Butte; GM, Grayback Mtn; IR, Indian Rock; JB, Jungle Butte; LHP, Lost Horse Plateau; MAE, Mount Adams East; SaP, Satus Pass; WDC, Willy Dick Canyon; WP, Windy Point; and WPB, White Pine Buttes (likewise all in Washington). Most are on the detailed USGS geologic map of the large area that includes Mount Adams, contiguous with the west margin of the present map and published previously (Hildreth and Fierstein, 1995).

Ages can be bracketed for most units, on the basis of mutual stratigraphic positions, numerous new ${ }^{40} \mathrm{Ar} /{ }^{39} \mathrm{Ar}$ age determinations (table 1), and a few K-Ar ages (appendix B). All units mapped are Pliocene or Quaternary, the boundary between which has recently been redefined to be $2.58 \mathrm{Ma}$ (Gibbard and others, 2009). Boundaries between early, middle, and late Pleistocene are widely agreed to be $\sim 780 \mathrm{ka}$ and $\sim 126$ ka (Gradstein and others, 2004). On this basis, most Simcoe volcanic rocks are of early Pleistocene age, many are Pliocene, a few are early middle Pleistocene, and only two eruptive units (apc and bgb) that flowed from vents in the adjacent Mount Adams volcanic field are late Pleistocene. The radioisotopic age determinations were made in the U.S. Geological Survey geochronology laboratory at Menlo Park, California, supervised by A.T. Calvert, following methods described in Calvert and Lanphere (2006).

The 223 volcanic unit descriptions that follow are arranged alphabetically by unit label, within groups of labels that begin with $\mathbf{a}$ for andesite, $\mathbf{d}$ for dacite, $\mathbf{b}$ for basalt, $\mathbf{m}$ for mafic (basaltic) andesite, $\mathbf{r}$ for rhyolite, and $\mathbf{t}$ for trachyte. Within the descriptions and the accompanying text, unit labels are printed in boldface to avoid confusion with three-letter words. 


\section{DESCRIPTION OF MAP UNITS}

\section{SURFICIAL DEPOSITS AND BASEMENT ROCKS}

al Alluvium and silt deposits (Holocene) - Stream gravel, sand, silt, and mud. Includes swamp deposits along some creekbeds. Widely omitted where thin, narrow, and discontinuous (as along upper Satus Creek). Silt and fine sand were widely deposited regionally by windstorms during glacial episodes in Cascade Range and contributed to thick soils covering most volcanic rocks. Much silt has been locally reworked by sheetwash and intermittent streams, eroded from highlands and concentrated in low-gradient lowlands such as Camas Patch and Starvation Flats, where resulting silt deposits now overlie parts of lava plateaus. Tan to pale-gray silt deposits are 1-4 m thick where exposed in arroyos and probably thicker beneath flats. Alternating seasonally, flats are floored by shallow ponds or mudflats in wet season and mudcracked hardpans during dry months. Such deposits are largely massive, their primary stratification presumably destroyed by bioturbation

Older alluvium (Holocene and Pleistocene) - Inactive stream and floodplain deposits of gravel, sand, silt, and mud, generally preserved as elevated terraces near or adjacent to present-day streams. Most are probably late Pleistocene or early Holocene, although a few such deposits perched on high plateaus (as on rim of Klickitat River canyon) may be as old as middle Pleistocene

cl Colluvium and talus (Holocene and Pleistocene) - Large patch mapped at mouth of Telephone Canyon consists mostly of slide masses and talus of unit $\mathbf{~ m s r}$ but includes clasts of rhyolite and unit Tcr. Large patch shown northwest of lower White Creek consists largely of rubble from cliffs of aphyric lavas above, as well as an extraordinarily thick blanket of loess; deposit conceals parts of units Tcr and bof, which underlie most of the colluvially mantled slope and plateau, respectively. Elsewhere in map area, thin colluvial cover and local talus are widespread but not shown

Landslide deposits (Holocene and Pleistocene) — Chaotic coarse rubble and numerous large rotated slump blocks that form extensive hummocky domains on north wall of Summit Creek and at Borde Flats on north slope of Klickitat River. Smaller slide masses are mapped at Lakebeds, Satus Creek, and lower White Creek. Both major slide masses are composite, having formed progressively by piecemeal rim collapse of plateaus of Simcoe lava flows adjacent to deepening gorges. Breakaway has generally taken place at or close to the base of Simcoe flows, where they overlie deeply weathered paleosurface of dense, less permeable Columbia River Basalt Group (unit Tcr). Although slide masses thus consist predominantly of Simcoe lava-flow debris, subordinate material from unit Tcr is also involved. Summit Creek mass covers $\sim 3.5 \mathrm{~km}^{2}$ and has a continuous rim scarp that cuts several Simcoe units. Borde Flats mass covers $8 \mathrm{~km}^{2}$ and has a headwall scarp in three segments, each providing its own proportions of lithologically varied debris region and make up principal basement rocks beneath Simcoe Mountains volcanic field. Main units of CRBG cropping out here are Grande Ronde Basalt (16.0-15.6 Ma) and Frenchman Springs, Roza, and Priest Rapids Members of Wanapum Basalt (15.6-14.5 Ma), as mapped by Bentley and others (1980) and not remapped by us. CRBG lavas are folded into a set of generally east-west-trending anticlines, part of Yakima Fold Belt, that dominates regional topography. Ridge along south edge of map area is one such anticline, and ridge alignment along north edge (Toppenish Ridge, Mike Coon Hillside, and Peavine Ridge) is another. Folding is thought to have begun long before eruption of most Simcoe flows, although several map units have been elevated and tilted by secular growth or local steepening of anticlines, and minor deformation may continue today. Spectacular cliffs along Klickitat River canyon expose CRBG sections as thick as $250 \mathrm{~m}$. Total topographic relief exposed on the CRBG in or adjacent to map area reaches $600 \mathrm{~m}$ at Pinegrass and Peavine Ridges, $750 \mathrm{~m}$ at Toppenish Ridge and at Simcoe Butte (just west of Satus Pass), and $850 \mathrm{~m}$ at Grayback Mountain (south wall of Summit Creek at map edge). Prominent landscape features, Logy Creek Falls (UTM grid 825/118; LCF) and Dry Creek Falls (729/144; CP) both drop over sheer cliffs of Frenchman Springs Member of Wanapum Basalt 


\title{
VOLCANIC ROCKS
}

\author{
[Listed alphabetically by three-letter map-unit label]
}

aec

apc

asi

awv

ayc

a72, a72'

Trachyandesite east of Castle Rock (Pliocene) - Phenocryst-rich lava flows (54.9-60.9\% $\mathrm{SiO}_{2}$ ) preserved as a 400-m-wide swath that caps the ridgecrest for $1.3 \mathrm{~km}$ eastward from Castle Rock and forms rugged south-facing rim of Satus Creek canyon. Ledges locally exposed below rim suggest at least three flows, together as thick as $60 \mathrm{~m}$. Ledges are block jointed or locally flow foliated, splitting slabby. Above rim, lava erodes into knobs and crags and decays into weathered piles of crumbly crystal-rich boulders. Phenocrysts: $15-20 \%$ plag (0.5-6 mm, but mostly small); sparse olivine and sparser cpx (both $\leq 1 \mathrm{~mm}$ ). Locally contains abundant relatively mafic blebs and enclaves, pale gray and fine grained. Overlies unit b59. Overlain by unit bcx. Undated. [SB]

Trachyandesite of Parrott Crossing (late Pleistocene)-Pyroxene andesite (59.5-60.0\% $\mathrm{SiO}_{2}$ ) intracanyon lava flow along Klickitat River (Sheppard, 1967b). Erupted from a nowconcealed vent near east foot of Mount Adams (Hildreth and Fierstein, 1995), flow entered Klickitat River gorge between Big Muddy and Cunningham Creeks, where its thickness reaches $170 \mathrm{~m}$; it spread $3 \mathrm{~km}$ up-gorge and at least $15 \mathrm{~km}$ down-gorge, entering the Outlet Falls quadrangle near Deer Creek $\sim 5 \mathrm{~km}$ above its present-day eroded terminus. Unit consists of a single cooling unit with glassy (vesicular to massive) zones 5 to $10 \mathrm{~m}$ thick enveloping a platy to massive crystalline interior; striking sets of columnar joints are widely developed. Covered by thick loessic soil and, near Big Muddy Creek, by glacial drift of at least two ages (Hildreth and Fierstein, 1995). Phenocrysts: $20-25 \%$ plag $(0.5-3 \mathrm{~mm}$, rarely $5 \mathrm{~mm}) ; 1-2 \%$ opx $(0.5-1.5 \mathrm{~mm}) ; 1-3 \%$ cpx $(0.5-2.5 \mathrm{~mm}) ;<1 \%$ FeTi oxides $(<0.5 \mathrm{~mm})$; and sparse olivine $(0.5-1.5 \mathrm{~mm})$. Younger than all contiguous units in map area; for relations with units farther west, see Hildreth and Fierstein (1995). K-Ar age: 120 $\pm 5 \mathrm{ka}$ (Hildreth and Lanphere, 1994). [OF, JB, G, MAE]

Trachyandesite of Simon Butte (early Pleistocene)-Aphyric lava flows and ejecta (55.5$58.3 \% \mathrm{SiO}_{2}$ ) that mantle the summit, upper north slope, and entire south slope of Simon Butte. Outcrops split platy to slabby, decaying into screes of plates and chips. Rock is finely crystalline, pale to medium gray, commonly weathering tan; groundmass plag microlites commonly impart glistening sheen. Sparse scoria bombs and vesicular blocks of agglutinate as big as $2 \mathrm{~m}$ are scattered on summit flat, which consists largely of nonvesicular aphyric flows. Radially, 25-80 m lower than summit flat, slopes are strewn with subordinate vesicular blocks as much as $50 \mathrm{~cm}$ across of phenocryst-rich unit bsi, presumably accidental ejecta. Two small windows of this aphyric unit crop out beneath younger flows along upper forks of Brush Creek, $2 \mathrm{~km}$ northeast and $2 \mathrm{~km}$ south of Simon Butte. Overlies unit bsi $(1,875 \pm 3 \mathrm{ka})$, which built much of Simon Butte Cone; also overlies units bem and bmb (2,079 $\pm 5 \mathrm{ka})$. Overlain by units b37, b85, bcr $(1,513 \pm 4 \mathrm{ka}), \mathbf{b m f}$, and bnf. Undated, but probably only slightly younger than unit bsi. [MB]

Trachyandesite west of Vessey Springs (early Pleistocene)—Phenocryst-poor lava flow (55.5$56.0 \% \mathrm{SiO}_{2}$ ) that crops out as low-relief window centered $\sim 1 \mathrm{~km}$ west of Vessey Springs.

Block-jointed lava, massive or weakly vesicular, forms 1-m-high ledges and scattered blocks and slabs in loessic soil. Phenocrysts: sparse plag $(1-6 \mathrm{~mm})$ and sparser olivine $(\leq 1 \mathrm{~mm})$. Plag microlites conspicuous on weathered blocks. Base not exposed. May be a more evolved, earlier-erupted phase of adjacent unit mvs. Overlain by units $\mathbf{m v s}$, bcp, and bgs $(1,531 \pm 4 \mathrm{ka})$. Undated. [MB]

Trachyandesite of Yatama Creek (Pliocene) - Phenocryst-rich lava flow (56.9-58.0\% $\mathrm{SiO}_{2}$ ) that crops out in a single window $(350 \times 600 \mathrm{~m}$ wide) at head of North Fork Yatama Creek, $2 \mathrm{~km}$ east of Tadpole Lake. Forms low benches, knobs, and ledges as well as weathered expanses of rounded joint blocks poorly exposed through soil and colluvium. Rocks are massive, partly glassy or devitrified, and flow foliated, commonly separating into plates and slabs $2-10 \mathrm{~cm}$ thick. Phenocrysts: abundant plag $(\sim 1 \mathrm{~mm})$, common olivine and opx (both $\sim 1 \mathrm{~mm})$, and sparse cpx (1-2 mm). Base not exposed. Overlain by units $\mathbf{m s l}(3,550 \pm 4 \mathrm{ka})$, mrw, and byt. May be older than adjacent unit ret. Undated. [SB]

Trachyandesite of Cone 3972 (Pliocene) - Phenocryst-poor lava flows and agglutinate (56.4$57.8 \% \mathrm{SiO}_{2}$ ) erupted at spatter Cone 3972 atop basement anticline, $7.5 \mathrm{~km}$ east of Signal Peak. Cone is mostly dense agglutinate, blobby to massive and block jointed, with few 
loose ejecta exposed. Flows, generally massive and slabby to block jointed, extend $2 \mathrm{~km}$ southeast to Tepee Creek; none went down steep north side of anticlinal ridge. Phenocrysts: almost aphyric; rare plag $(\leq 1 \mathrm{~mm})$, rare tiny olivine $(\leq 0.5 \mathrm{~mm})$, and a single 2-mm cpx were observed. Beneath southern tongue, on both sides of Tepee Creek, a local window of massive, dark-gray lava, intricately fractured in 10-30 cm angular fragments, is designated subunit a72'; it contains $1-2 \%$ plag $(1-3 \mathrm{~mm}), \sim 1 \%$ olivine $(0.5-1 \mathrm{~mm})$, and trace cpx $(1 \mathrm{~mm})$, and it may or may not have erupted from same vent. Unit a72 overlies unit Tcr. Overlain by units bsi $(1,875 \pm 3 \mathrm{ka}), \mathbf{b 3 1}, \mathbf{b 3 2}$, b33, and $\mathbf{m} 93 .{ }^{40} \mathrm{Ar} /{ }^{39} \mathrm{Ar}$ age: $3,273 \pm 12 \mathrm{ka}[\mathrm{PB}]$

bbc Trachybasalt of Bowman Creek divide (middle or early Pleistocene) - Phenocryst-poor lava flows and ejecta (47.5-50.7\% $\mathrm{SiO}_{2}$ ) erupted from a northwest-trending fissure vent along Simcoe Mountains rangecrest, $2.5 \mathrm{~km}$ southwest of Potato Butte. Eruption built two main piles of spatter, scoria bombs, and agglutinated cinders that support a pair of eroded knobs just south of rangecrest boundary road. Blocky to slabby lava flows form a steep apron that extends $2-3 \mathrm{~km}$ southwest to Bowman Creek (south of map area). Southeastern lava flow is compositionally less evolved $\left(47.5 \% \mathrm{SiO}_{2}\right)$ than near-vent ejecta $\left(50.5-50.7 \% \mathrm{SiO}_{2}\right)$. Phenocrysts: trace amounts of olivine, cpx, and plag (all $\leq 1 \mathrm{~mm}$ ). Overlies units Tcr and probably bpb $(822 \pm 3 \mathrm{ka})$. Undated. [HB, WPB]

bbe Trachybasalt east of Bear Creek (early Pleistocene or Pliocene)—Phenocryst-poor lava flows $\left(47.8 \% \mathrm{SiO}_{2}\right)$ exposed only in a 700- by $800-\mathrm{m}$ area overlapped by flows of Shield 2368 (unit b68) between Bear and Trout Creeks. Poorly exposed, weathered lava flows are massive or vesicular and mantled by thick colluvium and loessic soil. Phenocrysts: $<1 \%$ olivine $(\leq 1 \mathrm{~mm})$; rare fragments of plag megacrysts. Groundmass is typically rich in plag microphenocrysts and microlites. Vent covered by Shield 2368, of which this unit may be an early eruptive phase. Overlies unit bpc $(3,325 \pm 23 \mathrm{ka})$. Overlain by units $\mathbf{b 6 8}$ and bof

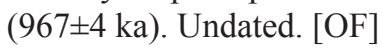

bbl Trachybasalt of Blue Creek (early Pleistocene)—Phenocryst-poor lava flows (48.3-49.7\% $\mathrm{SiO}_{2}$ ) that form 1- to 2-km-wide apron south of Blue Creek. Incised by Dry Creek tributary of Blue Creek. Erupted from a source later buried by younger units north of Hagerty Butte, lava flowed $\sim 10 \mathrm{~km}$ west, as far as junction of canyons of Brush and White Creeks. Flows are typically pale gray, mottled, fine grained, and massive, splitting platy, slabby, or blocky; vesicular facies is rarely preserved. Most of unit virtually aphyric; rare grains $(\leq 1 \mathrm{~mm})$ of olivine, cpx, and plagioclase can be found by diligent search. Tiny olivine $(\leq 0.2 \mathrm{~mm})$ is locally discernible where groundmass is atypically coarse. Plag microlites commonly impart sheen to joint faces. Youngest flow lobes, limited to proximal $2 \mathrm{~km}$ of exposure, carry $1-5 \%$ plag $(1-6 \mathrm{~mm})$ and sparse olivine $(\leq 1 \mathrm{~mm})$, but they are compositionally similar to rest of unit. Overlies units Tcr, b23, b34, bes, bsh (3,251 $\pm 7 \mathrm{ka})$, btb (3,262 $\pm 5 \mathrm{ka})$, and bw (1,885 $\pm 5 \mathrm{ka})$. Overlain by units bcr $(1,513 \pm 4 \mathrm{ka}), \mathbf{b c v}, \mathbf{b c v}$, bnb $(1,328 \pm 2 \mathrm{ka})$, and bhb $(1,276 \pm 4 \mathrm{ka}) .{ }^{40} \mathrm{Ar} /{ }^{39} \mathrm{Ar}$ age: $1,687 \pm 5 \mathrm{ka}$. [HB, TB]

bbw Basalt west of Bergie Springs (Pliocene) - Moderately phenocryst-rich lava flows and ejecta $\left(50.1-50.4 \% \mathrm{SiO}_{2}\right.$ ) of Cone 3282 between forks of Spring Creek $\sim 2 \mathrm{~km}$ west of Bergie Springs. Subdued cone is $500 \mathrm{~m}$ wide, $35-50 \mathrm{~m}$ high, and capped by layered agglutinate that grades outward into ledges of fountain-fed lava flows, which are platy or block jointed and widely vesicular. Largest surviving apron of flows extends only $600 \mathrm{~m}$ south of cone. Phenocrysts: $10-15 \%$ plag (1-3 mm); common cpx (1-4 mm); and sparser olivine (1-2 mm). Compositionally and petrographically similar to unit btw of adjoining Cone 3302 but slightly less silicic and alkalic and slightly richer in $\mathrm{Ca}$ and Al. Overlies unit Tcr. Overlain by unit bta $(3,464 \pm 4 \mathrm{ka})$. Undated but probably similar in age to adjacent unit btw $(3,325 \pm 45 \mathrm{ka})$. [LCF]

bcc Trachybasalt of Clock Creek (early Pleistocene or Pliocene)—Aphyric lava flows (48.4$49.7 \% \mathrm{SiO}_{2}$ ) that cap plateau north of Toppenish Creek, extending $\sim 4.5 \mathrm{~km}$ east-west along north edge of map area. Plateau is incised and bounded by Clock Creek 1-2 km north of map edge. Maximum thickness exposed is $150 \mathrm{~m}$ at east rim of plateau; thins to $40-70 \mathrm{~m}$ along rims to north and west. Source vent presumed to lie in upper Clock Creek, north of map area. Plateau surface is loess-covered with little outcrop. Rimrock outcrops are block jointed, ledgy, massive, and seldom vesicular. Phenocrysts: typically none, although very rare plag (to $1 \mathrm{~mm}$ ) does occur. Groundmass has abundant tiny plag and olivine (both $<0.3$ $\mathrm{mm}$ ), conspicuous in weathered rocks. Rests on unit Tcr but in contact with no other unit 
within or near map area. Somewhat varied chemical compositions among several samples suggest correlations with units boc, bwt, and bdl, all south of Toppenish Creek gorge, but investigation of unit bcc north of map area is incomplete. Undated. [MB, PB, LHP, WDC]

bcd Trachybasalt of Cedar Creek (middle Pleistocene) - Sparsely to moderately porphyritic lavas and ejecta (48.1-48.5\% $\mathrm{SiO}_{2}$ ) erupted at 85 -m-high scoria cone $\sim 1.5 \mathrm{~km}$ northwest of Kaiser Butte Guard Station. Cone consists of lapilli, blocks, and bombs, mostly oxidized and nearly all vesicular. A 700-m-wide rubbly lava flow extends $3 \mathrm{~km}$ westward, forming north bank of Cedar Creek. Phenocrysts: $3-8 \%$ plag $(1-8 \mathrm{~mm})$ and sparse tiny olivine; cpx is rare or absent. Rests on units Tcr and bkb (688 $\pm 25 \mathrm{ka})$. Overlain by unit bfc ( $681 \pm 2 \mathrm{ka})$. Undated. [HB, TB]

bcf Trachybasalt of South Fork Camp (early Pleistocene)—Phenocryst-poor lava flow (48.8\% $\mathrm{SiO}_{2}$ ) exposed only as 600-m-long window through unit bsd, just south of campsite where Dry Creek Road crosses South Fork Dry Creek. Cropping out locally as ledges or as colluvium-mantled massive joint blocks, flow may be a weakly porphyritic variant of nearby aphyric unit bds, which it closely matches chemically. Phenocrysts: $2-3 \%$ plag $(1-2 \mathrm{~mm})$ and sparse 1-mm olivine. Base not exposed. Overlain only by unit bsd. Undated. [CP]

bcl Trachybasalt of Campbell Line (Pliocene) - Extremely phenocryst-poor lava flows (47.3$48.1 \% \mathrm{SiO}_{2}$ ) exposed on and near the rim of landslide scarp north of Summit Creek. As basal Simcoe flows in the area, unit rests on unit Tcr and caps plateau above confluence of Summit Creek with Klickitat River. One or two flows are together 30-40 m thick along south-facing scarp, but unit thickens westward into a 75-m package of 5 or 6 flows on westfacing rim of Klickitat River canyon, apparently filling paleotributary topography. Individual flows are massive, mottled, slabby to block jointed, and range in thickness from 5 to $25 \mathrm{~m}$; thicker (generally earlier) flows have columnar basal zones. Rock is nearly aphyric, having far fewer crystals than overlying crystal-poor unit bsh. Very rare plagioclase megacryst fragments and 1-mm olivine are found by diligent search. Overlies unit Tcr. Overlain by units b82 and bsh $(3,251 \pm 7 \mathrm{ka}) .{ }^{40} \mathrm{Ar} /{ }^{39} \mathrm{Ar}$ age: $3,298 \pm 10 \mathrm{ka}$. [TB, OF, DC]

bcp Trachybasalt of cinder pits west of Vessey Springs (early Pleistocene)—Phenocryst-rich lava flows and ejecta $\left(47.8-48.4 \% \mathrm{SiO}_{2}\right)$ that erupted at 150-m-high scoria Cone $3720+$ (marked by quarries on its south side) that stands $1.5 \mathrm{~km}$ west of Vessey Springs. Quarries expose bombs and blocks as big as $50 \mathrm{~cm}$, many dark gray, but cone consists predominantly of oxidized red cinders. A 2-km-wide lava-flow apron extends $4.5 \mathrm{~km}$ west and southwest from the cone, between forks of Brush Creek. Phenocrysts: $10-15 \%$ plag $(1-5 \mathrm{~mm}) ; 2-3 \%$ olivine (mostly microphenocrysts but as big as $1 \mathrm{~mm}$ ); sparse 1-mm cpx; and sparse fragments of plag megacrysts as big as $10 \mathrm{~mm}$. Undated but younger than all contiguous units; overlies units awv, mvs, b60, bns $(1,566 \pm 3 \mathrm{ka})$, bmb $(2,079 \pm 5 \mathrm{ka})$, and bgs $(1,531 \pm 4 \mathrm{ka})$. [MB, HB, TB]

bcr, Trachybasalt of Coyote Springs Road (early Pleistocene)—Phenocryst-rich lava flows bcr' $\quad\left(46.9-48.4 \% \mathrm{SiO}_{2}\right)$ that erupted from a predominantly effusive vent $2 \mathrm{~km}$ west of Simon Butte. Proximal crystal-rich agglutinate atop vent Hill $3420+$ is draped on its east flank and southeast spur by a more oxidized agglutinate (subunit $\mathbf{b c r}^{\prime}$ ) that is poorer in phenocrysts and chemically slightly more evolved but has same phenocryst assemblage. Lava flows form a multi-lobate apron, including one major tongue (as thick as $30 \mathrm{~m}$ medially) that extends $16 \mathrm{~km}$ southwest, capping a plateau along west side of Brush Creek almost as far as its junction with White Creek; remnants as thick as $15 \mathrm{~m}$ are banked against canyon walls near or just below rim on both sides of White Creek gorge for an additional $4 \mathrm{~km}$ downstream. Just upstream from Cedar Valley Road bridge, an intracanyon outlier forming both walls of White Creek is an erosionally isolated lobe of main flow. Most outcrops are coarsely block jointed, massive, and rarely vesicular; unit forms ledges and knobs and decays to rounded boulders. Phenocrysts: $10-15 \%$ plag (mostly $1-5 \mathrm{~mm}$; rarely as big as $30 \mathrm{~mm}$ ); $1-4 \%$ olivine (1-4 mm); and sparse to common cpx (mostly $1-2 \mathrm{~mm}$; rarely to $8 \mathrm{~mm}$ ). Overlies units asi, b63, b73', bbl (1,687 $\pm 5 \mathrm{ka})$, bmb (2,079 $\pm 5 \mathrm{ka})$, bns (1,566 $\pm 3 \mathrm{ka})$, bsh $(3,251 \pm 7 \mathrm{ka})$, bsi $(1,875 \pm 3 \mathrm{ka})$, bsw, and bw (1,885 $\pm 5 \mathrm{ka})$; banks against units bpc $(3,325 \pm 23 \mathrm{ka}), \mathbf{b s p}$, btb $(3,262 \pm 5 \mathrm{ka})$, and bwe. Overlain by units bpo $(1,101 \pm 3 \mathrm{ka})$ and boh $(981 \pm 14 \mathrm{ka}) .{ }^{40} \mathrm{Ar}{ }^{39} \mathrm{Ar}$ age: $1,513 \pm 4 \mathrm{ka}$. [MB, PB, TB]

bcs Basalt of Camas Patch (early Pleistocene) - Phenocryst-poor lava flows (47.3-50.7\% $\mathrm{SiO}_{2}$ ) that floor lowlands between Middle Fork and South Fork Dry Creek. May have erupted 
during an early phase of activity near Smith Butte to south and flowed from present area of White Fir Creek for $9 \mathrm{~km}$ across Camas Patch flats to rims of Dry Creek canyon. Camasrich "patches" are flat open meadows, either strewn with rounded blocks of weathering basalt or shallow silt-filled depressions on basalt surface. Rocks are slabby or block jointed, ledgy on canyon walls, generally fine grained and massive, and seldom vesicular except near base of unit. Total thickness is as great as $75 \mathrm{~m}$ where incised by Middle Fork but only $10-20 \mathrm{~m}$ on rims elsewhere. Phenocrysts: generally aphyric, but widely contains traces of olivine (0.3-2 $\mathrm{mm})$ and rare 1-30 $\mathrm{mm}$ fragments of plag megacrysts. Local meter-scale domains in aphyric host lava contain swarms of olivine and cpx megacrysts (each to 5 $\mathrm{mm}$, some mutually intergrown) and plag fragments $(10-30 \mathrm{~mm})$, suggesting entrainment and disaggregation of cumulates. Unit is widely mantled by a few meters of massive tan to pale-gray silty mud (al). Knoll 3555 near northeast edge of Camas Patch is a 20-mhigh knob of basalt (with no ejecta, oxidation, or obvious agglutinate), probably a site of secondary upwelling of lava; if therefore a large tumulus, it suggests that parts of the lowland sheet contained lava tubes. Rests on units Tcr, bdf, bfr, and bsd. Also apparently laps against cones bc2, bc6, and bc8, but contacts are obscure. Overlain by units b90, bgs $(1,531 \pm 4 \mathrm{ka})$, bnf $(1,533 \pm 3 \mathrm{ka})$, bsn $(1,479 \pm 3 \mathrm{ka})$, and bwf. Age relation with unit bs $(1,722 \pm 5 \mathrm{ka})$ uncertain. K-Ar age: $1,882 \pm 48 \mathrm{ka} .{ }^{40} \mathrm{Ar} /{ }^{39} \mathrm{Ar}$ age: $1,609 \pm 2 \mathrm{ka}$. [MB, CP]

bcv, Trachybasalt of Cedar Valley Road (early Pleistocene) - Major lava flow apron (47.8-48.9\% $\mathrm{SiO}_{2}$ ) that emerges from beneath Hagerty Butte flows and extends $9 \mathrm{~km}$ southwest to Summit Creek; erupted from a vent now concealed by Hagerty Butte center. Knobby outcrops are typically block jointed, rarely slabby, but most surfaces are disintegrating rubble in thick loessic soil. Phenocrysts: range in crystal content (5-15\%) with olivine generally dominant. Olivine (3-8\%) is typically $1-5 \mathrm{~mm}$ (rarely to $8 \mathrm{~mm}$ ) and occurs only sparsely as microphenocrysts; cpx (1-3\%) is mostly $1-3 \mathrm{~mm}$ but as big as $8 \mathrm{~mm}$; plag content ranges widely (1-8\%) and is generally more abundant distally; most plag is $1-5 \mathrm{~mm}$ but also occurs locally as megacryst fragments as big as $10-15 \mathrm{~mm}$. Near terminus at Summit Creek, flow has more feldspar and generally larger crystals of all three kinds. Overlies units Tcr, b82, bbl, bes, bsc, and bsh (3,251 $\pm 7 \mathrm{ka})$. Overlain by unit bhb $(1,276 \pm 4 \mathrm{ka})$. A proximal lava-flow lobe $\left(48.9 \% \mathrm{SiO}_{2}\right) \sim 1 \mathrm{~km}$ wide that overlies main bcv flow is designated subunit bcv'; $\sim 3 \mathrm{~km}$ west of Hagerty Butte, both are overlapped by olivine-rich lava flows of Hagerty Butte center. Chemically indistinguishable from bcv, subunit bcv' contains $\sim 15 \%$ phenocrysts, with plag dominant (unlike most bcv), but plag, cpx, and olivine are all abundant and each is as big as $8-10 \mathrm{~mm}$. Undated. [TB]

bcw Basalt west of Castle Rock (Pliocene)—Distinctive olivine-rich lava flows (47.2-48.1\% $\mathrm{SiO}_{2}$ ) high on Castle Rock Shield north of upper Satus Creek. Unit caps Hill 5540+ (1 km northwest of Castle Rock) and crops out over an area that extends $2 \mathrm{~km}$ north-south and 1.5 $\mathrm{km}$ east-west from Satus Creek rim to South Fork Logy Creek. Exposures form slabby or block jointed ledges and knobs. No agglutinate or scoria observed; vent not located, possibly eroded by Satus Creek canyon or concealed by unit bcx. Phenocrysts: $10-15 \%$ olivine (1-3 mm), some clustered; 0.5-4\% plag (1-5 mm); and sparse to common cpx (1-2 mm). Contains sparse angular fragments $(10-20 \mathrm{~mm})$ of cpx-olivine-plag gabbro. Additionally, on southwest rim of Hill 5540+, unit encloses numerous domains of apparent cumulate mush entrained by host magma; most are smaller than a few meters but largest observed is $8 \mathrm{x}$ $20 \mathrm{~m}$ in outcrop area. Cumulate domains are medium gray, lack mineral layering or fabric, and have fine angular (diktytaxitic) porosity as well as common round vesicles (1-2 mm) and sparse vugs; domains consist of $>80 \%$ crystals coarser than $1 \mathrm{~mm}$, mostly $1-2 \mathrm{~mm}$, but including scattered olivine as big as $3 \mathrm{~mm}$ and plag laths as long as $4 \mathrm{~mm}$; phase proportions vary, but they generally have $\sim 75 \%$ plag, $20 \%$ olivine, and subordinate cpx. Overlies units msl $(3,550 \pm 4 \mathrm{ka})$, rsc, and b59. Overlain by units blw and bcx. Undated. [SB]

bcx Trachybasalt of Castle Rock (Pliocene)-Plagioclase-rich lava (48.4-50.1\% $\mathrm{SiO}_{2}$ ) that forms 30-m-high castellate knob that crowns high point of Castle Rock shield north of Satus Creek canyon. Crops out boldly with steep joints spaced $2-5 \mathrm{~m}$ apart that separate roundedged sheets and columns. Crystal-rich rock is massive, weathering pale gray and grussy and decaying into a radial apron of rounded blocks (1-5 $\mathrm{m}$ across) fallen from steep central knob. Also crops out poorly as nonvesicular flows for $500 \mathrm{~m}$ northwest and $\sim 1 \mathrm{~km}$ northeast of Castle Rock knob, which may have been a plug. Phenocrysts: 20-50\% plag (1-20 mm); 
trace amounts of olivine and rarer cpx (both $0.5-5 \mathrm{~mm}$ ). Included within this host are blobs, dikes, and irregular segregations $(0.1-1 \mathrm{~m})$ of medium-gray hackly basalt $\left(47.5 \% \mathrm{SiO}_{2}\right)$ that carry only $10-15 \%$ plag $(5-15 \mathrm{~mm}$, as in host), roughly one third as much as in host. Intrudes or overlies units aec, $\mathbf{m s l}(3,550 \pm 4 \mathrm{ka})$, bcw, and b59. Undated. [SB]

bc2 Trachybasalt of Cone 3572 (early Pleistocene)-Phenocryst-poor agglutinate $\left(49.2 \% \mathrm{SiO}_{2}\right)$ of small spatter and lava cone $\sim 1 \mathrm{~km}$ south of meadows of Camas Patch. Cone is $300 \mathrm{~m}$ wide, has $25 \mathrm{~m}$ relief, and is capped by moderately to densely welded agglutinate that ranges from vesicular to massive, block jointed to platy, and locally retains primary fallout bedding. Phenocrysts: trace amounts of olivine and plag (each $0.5-2 \mathrm{~mm}$ ) and rare fragments as big as $10 \mathrm{~mm}$ of shattered plag megacrysts. Base not exposed. Overlain by unit bsn $(1,479 \pm 3 \mathrm{ka})$ and surrounded by unit bcs $(1,882 \pm 48 \mathrm{ka})$, which we think is younger. Undated. [CP]

bc5, Trachybasalt of Cone 3895 (early Pleistocene)-Moderately phenocryst-rich ejecta and bc5' fountain-fed lava flows $\left(48.3-48.7 \% \mathrm{SiO}_{2}\right)$ of small spatter cone on east wall of upper Spring Creek. Cone is $500 \mathrm{~m}$ wide, $50 \mathrm{~m}$ high, and capped by dense agglutinate and sparse red scoria. Steep east slope exposes several separate flows. Lava flows on crest and slopes are generally massive and block jointed. Phenocrysts: $\sim 10 \%$ plag $(1-10 \mathrm{~mm})$, common olivine (1-2 mm), and sparse cpx (1-3 mm). Late phase of activity released contrasting magma that produced a 100-m-wide lava flow (subunit $\mathbf{b c 5}^{\prime}$ ) that drapes west side of cone; vesicular atop cone, it consists of massive joint blocks on west slope. Subunit bc5' has $51.2 \% \mathrm{SiO}_{2}$, lacks plag and cpx, and contains $\sim 5 \%$ olivine (1-2 $\mathrm{mm}$, rarely to $4 \mathrm{~mm}$ ). Overlies units bgp and bsu. Undated. [SB, CP]

bc6 Trachybasalt of Cone 3606 (early Pleistocene)—Phenocryst-poor agglutinate and lava apron $\left(47.7 \% \mathrm{SiO}_{2}\right)$ of small spatter cone $2 \mathrm{~km}$ south of Camas Patch meadows and $500 \mathrm{~m}$ east of White Fir Creek. Cone is $600 \mathrm{~m}$ wide and $30 \mathrm{~m}$ high. Outcrops are largely massive, hackly, or block jointed; sparse red cinders are scattered on slopes. Lava-flow shelf at north edge of cone, probably fountain-fed, has only 1-3 m relief. Phenocrysts: rare olivine and plag (both $\leq 1 \mathrm{~mm}$ ) plus rare olivine megacrysts as big as $7 \mathrm{~mm}$ and sparse fragments (to $10 \mathrm{~mm}$ ) of shattered and (or) rounded plag megacrysts. Base not exposed. Older than adjacent unit bcs $(1,882 \pm 48 \mathrm{ka})$ and overlain by unit bsn $(1,479 \pm 3 \mathrm{ka})$. Undated. [CP]

bc8 Trachybasalt of Cone 3580 (early Pleistocene)-Mafic agglutinate and lava flows (47.8-48.7\% $\mathrm{SiO}_{2}$ ) of small spatter cone, $1 \mathrm{~km}$ southeast of Camas Patch meadows, just south of Dry Creek Road. Cone is $\sim 600 \mathrm{~m}$ across and $30 \mathrm{~m}$ high. Joint blocks of vesicular lava are widespread, but no loose scoria observed. Phenocrysts: on slopes, blocks are phenocrystpoor, containing only sparse plag $(\leq 1 \mathrm{~mm})$, olivine $(0.5-2 \mathrm{~mm})$, and rare cpx $(1-2 \mathrm{~mm})$; locally, also carries fragments $(1-5 \mathrm{~mm})$ of shattered plag megacrysts. In contrast, on summit plateau and upper southwest slope, most blocks have 5-10\% plag $(1-10 \mathrm{~mm})$ and sparse 1-mm olivine. Base not exposed. Cone is surrounded by units bcs $(1,882 \pm 48 \mathrm{ka})$ and bs $(1,722 \pm 5 \mathrm{ka})$, both presumed younger (but poorly exposed contacts are ambiguous). Undated. [CP]

bdf Trachybasalt of Dry Creek Falls (early Pleistocene)—Phenocryst-poor lava flow (48.3-48.7\% $\mathrm{SiO}_{2}$ ) that caps plateaus on both rims of canyon of lower South Fork Dry Creek. Extends 3.5 $\mathrm{km}$ eastward, past Dry Creek Falls, to rim above confluence of forks. Source vent buried by younger units to west or southwest. Crops out on rim as massive lava flow 4-10 $\mathrm{m}$ thick, slabby or block jointed. Streambed at Dry Creek Falls is cut in unit Tcr, 30-70 m below rimrock unit bdf. Phenocrysts: $\sim 1 \%$ olivine $(1-3 \mathrm{~mm}$ ) plus scattered olivine megacrysts (7-10 mm); sparser plag $(1-3 \mathrm{~mm})$ plus rare plag megacrysts; free cpx rare but as big as 8 $\mathrm{mm}$. Clusters as big as $10 \mathrm{~mm}$ of $1-\mathrm{mm}$ olivine and cpx crystals are present but uncommon, as are 10-mm intergrowths of plag and cpx. Overlies units Tcr and bds. Overlain by units bsd and bcs $(1,882 \pm 48 \mathrm{ka})$. Undated. [CP, LCF]

bdl Basalt of Delaney Spring (Pliocene) - Phenocryst-poor lava flows (49.2-50.1\% $\mathrm{SiO}_{2}$ ) that crop out as a 1.5-km-long strip downstream from Delaney Spring along Surprise Creek, a contiguous 700-m-long bench along south rim of Toppenish Creek, and an isolated 500-mlong bench apparently elevated on the basement anticline, $1.5 \mathrm{~km}$ east of Delaney Spring. Maximum thickness exposed is 50-60 m. Exposures are block jointed or slabby, massive or finely vesicular (commonly diktytaxitic), and have conspicuous snowstorm groundmass rich in plag microlites. Oxidized, rubbly, vesicular flow top has been exposed at Delaney Spring by quarrying of overlying unit boc. Phenocrysts: few $>0.5 \mathrm{~mm}$; olivine microphenocrysts 
are commonly well developed but rarely as big as $0.5 \mathrm{~mm}$; rare phenocrystic plag $(0.5-1 \mathrm{~mm})$. Scattered clots of olivine+plag microphenocrysts are as big as $2 \mathrm{~mm}$, and sparse angular fragments consisting of tens of intergrown plag+olivine crystals $(<0.3 \mathrm{~mm})$ are as big as $10 \mathrm{~mm}$. Rests on unit Tcr. Overlain by units boc $(2,136 \pm 5 \mathrm{ka})$ and btp. Undated. [MB]

bdr Trachybasalt of Deer Creek (early Pleistocene or Pliocene)-Phenocryst-poor olivine basalt (49.4-51.5\% $\mathrm{SiO}_{2}$ ) lava flows and twin scoria cones along Peavine Ridge road just east of Deer Creek. Contiguous cones are together $\sim 1 \mathrm{~km}$ long, aligned northwest; banked against canyon sidewall, they have little relief on their northeast side but as much as $150 \mathrm{~m}$ on southwest. Ejecta of scoria cones are mostly oxidized, finely to coarsely vesicular, and include bombs as big as $50 \mathrm{~cm}$. Lava flows are massive or sparsely vesicular, deeply weathered, and covered by thick loessic soil and colluvium with rounded corestones. An erosional remnant $2 \mathrm{~km}$ west, on opposite (west) rim of Klickitat River canyon, is a 30 -m-thick lava flow, its base $\sim 150 \mathrm{~m}$ above present-day river level (Hildreth and Fierstein, 1995). Phenocrysts: $0.5-2 \%$ olivine $(0.5-2 \mathrm{~mm})$, seriate to abundant groundmass olivine $(0.1-0.5 \mathrm{~mm})$; phenocrystic plag and cpx rare (each $0.5-1 \mathrm{~mm})$. Contains sparse fragments

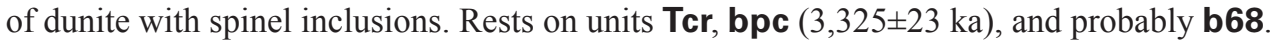
Older than contiguous units bof $(967 \pm 4 \mathrm{ka})$ and $\mathbf{b j b}(1,350 \pm 50 \mathrm{ka})$. Undated. [OF, G]

bds, Trachybasalt south of Dry Creek (early Pleistocene or Pliocene)—Phenocryst-poor lava bds' flows (48.6-49.2\% $\mathrm{SiO}_{2}$ ) that extend $\sim 6 \mathrm{~km}$ eastward along and south of Dry Creek Road as far as canyon rim $\sim 2 \mathrm{~km}$ east of Dry Creek Falls. A small window is also exposed through unit bsd along South Fork Dry Creek. Flows are massive and block jointed or slabby. Phenocrysts: generally aphyric but carries rare fragments $(4-8 \mathrm{~mm})$ of plag megacrysts. Groundmass locally rich in plag microlites, with or without traces of plag or olivine microphenocrysts. A distal flow at Dry Creek rim (UTM 750/140), also aphyric, displays markedly coarser groundmass and is mapped as subunit bds'. Overlies units Tcr, $\mathbf{m s g}$, and $\mathbf{m t w}$. Overlain by units bdf, bgp, bsd, and $\mathbf{m n s}$. Undated. [CP, LCF]

beb

Basalt east of Bowman Creek (Pliocene)-Phenocryst-rich lava flows (48.0-49.1\% $\left.\mathrm{SiO}_{2}\right)$ that crop out beneath lavas of unit b58 on western slope of Simcoe Shield $2 \mathrm{~km}$ southwest of Lakebeds. From exposures at elevations as high as $5,380 \mathrm{ft}$, lava flows descend west and southwest for at least $4 \mathrm{~km}$ to headwaters of Mill Creek, south of map area. Vent buried by younger units higher on shield to northeast. Outcrops are low-relief ridges and ledges, generally massive and block jointed. Phenocrysts: $10-20 \%$ plag $(1-3 \mathrm{~mm}), 3-5 \%$ olivine $(0.5-2 \mathrm{~mm})$, and sparse cpx (1-2 mm). Base not exposed within map area; distal relations not mapped. Overlain by unit b58 (700 $\pm 30 \mathrm{ka})$. May be equivalent to unit bld $(3,841 \pm 14$ ka). Undated. [SB, IR, WPB]

bec Trachybasalt of Elk Creek (Pliocene)—Phenocryst-poor lava flow $\left(46.9 \% \mathrm{SiO}_{2}\right.$ ) exposed as a narrow 2-km-long strip along Elk Creek, 2-4 km north of Klickitat River. Relief nowhere exceeds $15 \mathrm{~m}$, and exposure is poor, generally limited to colluvial rubble and corestones in thick loessic soil. Phenocrysts: $<1 \%$ olivine $(\leq 1 \mathrm{~mm})$ and rare cpx $(1-4 \mathrm{~mm})$; no plag phenocrysts but shattered fragments of plag megacrysts are as large as $10 \mathrm{~mm}$. Rests on units b81 and bpc ( $3,325 \pm 23 \mathrm{ka})$; overlain by unit boh ( $981 \pm 14 \mathrm{ka})$. Undated. [OF]

bem Trachybasalt east of McKays Butte (early Pleistocene)—Phenocryst-poor lava flows (47.9$49.5 \% \mathrm{SiO}_{2}$ ) exposed as a rolling low-relief area $3 \mathrm{~km}$ across, directly east of McKays Butte; exposure also extends $2 \mathrm{~km}$ westward along north wall of Hoppers Flat fork of Brush Creek. Source vent probably atop small Shield $3560+$, capped by agglutinate but little scoria. Crops out as massive joint blocks and slabs, virtually aphyric but with characteristically granular groundmass, typically rich in plag microlites. Thickness exposed is generally $15-25 \mathrm{~m}$ but as great as $30 \mathrm{~m}$ along wall of Brush Creek. Springs emerge from block-jointed flow front 500 $\mathrm{m}$ northwest of Hoppers Flat. Phenocrysts: typically none, but traces of tiny olivine and plag occur locally, as do sparse fragments of plag megacrysts $(5-15 \mathrm{~mm})$. Overlies unit bhf and apparently banks against bmb $(2,079 \pm 5 \mathrm{ka})$. Overlain by units $\mathbf{t 3 9}$, b39, bgs $(1,531 \pm 4 \mathrm{ka})$, bmf, b90, bwf, and asi. Undated. [MB]

beo Trachybasalt east of OIney Creek (early Pleistocene)-Plagioclase-rich ejecta and lava flows (49.3-49.6\% $\mathrm{SiO}_{2}$ ) erupted at site of scoria-and-spatter Cone 3560+ between headwaters of Olney and Camp Creeks at north margin of Toppenish Ridge Anticline. Scoria, conecapping agglutinate, and lava flows represent late phase of cone activity, succeeding earlier 
eruption of phenocryst-poor unit bor. Near-vent agglutinate is partly oxidized, ranging from tack welded through blobby and knobbly to massive and block jointed. Lava-flow apron, generally massive and block jointed, extends $2.5 \mathrm{~km}$ north and northeast to rim of Toppenish Creek canyon, where unit is as thick as $15-25 \mathrm{~m}$. Phenocrysts: $15-20 \%$ plag $(1-15 \mathrm{~mm})$; sparse (but locally common) olivine $(\leq 1 \mathrm{~mm})$. Overlies units bor and boc $(2,136 \pm 5 \mathrm{ka})$. No contiguous units are younger. Undated. [MB]

bes Trachybasalt east of Schafer Creek (early Pleistocene)—Phenocryst-rich lava flows (47.8$48.4 \% \mathrm{SiO}_{2}$ ) that erupted from a vent now buried by younger units near or north of Hagerty Butte. Flow field, 1-2 km wide, emerges from under unit bbl in upper Schafer Creek and extends $6 \mathrm{~km}$ southwest to a well-defined lobate flow-front along and east of Schafer Creek. Flows are generally massive and block jointed, cropping out as ledges and knobs or as rounded blocks in loessic soil. Phenocrysts: $10-15 \%$ plag $(1-8 \mathrm{~mm})$ plus scattered megacryst fragments as big as $10-15 \mathrm{~mm}$; relatively sparse olivine $(1-3 \mathrm{~mm})$ and still sparser cpx $(\leq 1 \mathrm{~mm})$. Overlies units bsh $(3,251 \pm 7 \mathrm{ka}), \mathbf{b 6 6}$, and b23. Overlain by units

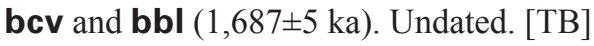

bew Basalt east of White Creek (Pliocene) - Phenocryst-poor lava flows (47.4-47.5\% $\mathrm{SiO}_{2}$ ) that crop out only in a 1.5-km-long exposure east of upper White Creek, 4-5 km east of Signal Peak. Stream-incised massive unit is slabby to block jointed and has $\sim 65 \mathrm{~m}$ local relief. Vent concealed by younger units. Nearly aphyric lava flows are distinguished from adjacent phenocryst-poor units by trace contents of olivine $(0.5-3 \mathrm{~mm}$, some in clusters), rare plag, and still rarer cpx. Overlies unit bsz $(3,323 \pm 6 \mathrm{ka})$. Overlain by units $\mathbf{m s p}(3,286 \pm 6 \mathrm{ka})$ and bwh. Undated. [PB]

bfc Trachybasalt of Featherbed Creek (middle Pleistocene)—Phenocryst-poor basalt (49.0-50.0\% $\mathrm{SiO}_{2}$ ) erupted at 200-m-high scoria Cone $4120+$ on north flank of Simcoe Mountains Anticline, $2 \mathrm{~km}$ northeast of Kaiser Butte Guard Station. Cone consists of oxidized agglutinate and loose black and red scoria. One narrow lava tongue extends $5 \mathrm{~km}$ northwest to Summit Creek; another extends $10 \mathrm{~km}$ westward, generally forming south bank of Featherbed Creek as far as its confluence with Summit Creek. Lava flows are typically massive, locally sparsely vesicular. Flows and scoria are generally phenocryst-free but locally contain sparse grains of olivine and plag (each rarely as big as $1 \mathrm{~mm}$ ) and scattered fragments of plag megacrysts as big as $8 \mathrm{~mm}$. Erupted through and overlies unit Tcr. Younger than all other contiguous units - bcd, bhb (1,276 $\pm 4 \mathrm{ka})$, bkb (688 $\pm 25 \mathrm{ka})$, bnk, bos, bpb $(822 \pm 3 \mathrm{ka})$, bsc $(1,675 \pm 5 \mathrm{ka})$, and bws. ${ }^{40} \mathrm{Ar} /{ }^{39} \mathrm{Ar}$ age: $681 \pm 2 \mathrm{ka}$. [HB, TB]

bfr Feldspar-rich trachybasalt north and south of Smith Butte (Pliocene) —Plagioclase-rich lava flows (47.2-49.1\% $\mathrm{SiO}_{2}$ ) that crop out boldly along a belt that extends $12 \mathrm{~km}$ northward from elevations as high as 5,400 ft on west wall of upper South Fork Logy Creek, passing beneath east flank of Smith Butte, to as low as 3,500 ft at south margin of Camas Patch lowland. Main belt terminates in a divergent pair of steep flow lobes that support rugged ridges $2 \mathrm{~km}$ south of Camas Patch; but two small windows adjacent to Camas Patch show unit to continue northward beneath lowland-mantling unit bcs. Four additional windows are exposed northeast of Smith Butte, 2-7 km from its summit. An outlying remnant caps divide between North and South Forks Logy Creek at 4,300 ft elevation. Twelve samples analyzed are fairly similar chemically and not strongly enriched in $\mathrm{Al}_{2} \mathrm{O}_{3}(16.7-18.8 \%)$. Greatest thicknesses exposed are $\sim 60 \mathrm{~m}$ in south and $90 \mathrm{~m}$ near northern terminus. Erupted high on Castle Rock shield, possibly at Castle Rock vent itself (unit bcx). Forms block-jointed ledges and bold knobs, massive and rarely vesicular, that decay into piles of rounded boulders (1-4 m across), which are rough-surfaced, knobbly, and commonly grussy. Phenocrysts: $15-40 \%$ plag $(5-20 \mathrm{~mm})$ and sparse to common olivine $(0.5-2 \mathrm{~mm})$. Distinguished from certain flows that carry $10-15 \%$ large plag in adjacent unit bld by absence of cpx. Locally, as best exposed on Knob 5254 (3 km east of Stagman Butte), plagioclase-rich host is marbled by dikes and veins of aphyric basalt, which presumably reflects separation of interstitial melt in domains locally under tensile stress during outflow of viscous host lava; dikes are slightly depleted in $\mathrm{Al}, \mathrm{Mg}$, and Ca but modestly enriched in all other major elements. Dikes are finely holocrystalline, $10-30 \mathrm{~cm}$ thick, as long as several meters, and exhibit sharp but crenulate, wavy, or lobate contacts against coarsely porphyritic host; some dikes branch into veinlets as thin as $2 \mathrm{~mm}$, and isolated gash veins and thin aphyric lenses are also common. Overlies units $\mathbf{~ m s l}(3,550 \pm 4 \mathrm{ka})$, bnl, and bld $(3,841 \pm 14$ 
ka). Overlain by units b47, bcs $(1,882 \pm 48 \mathrm{ka})$, blw, brs, bs $(1,722 \pm 5 \mathrm{ka})$, bsd, bsn $(1,479 \pm 3 \mathrm{ka})$, and $\mathbf{m n s}$. Undated. [SB, CP]

bgb Basalt of Glaciate Butte (late Pleistocene)—Phenocryst-rich intracanyon lava flows (51.2$52.5 \% \mathrm{SiO}_{2}$ ) along Klickitat River gorge and its west fork (Fish Lake Stream, in northwest corner of map area). Erupted at Glaciate Butte scoria cone on lower northeast slope of Mount Adams, northwest of map area (Hildreth and Fierstein, 1995); flows extended at least $25 \mathrm{~km}$ down-canyon. Exposures are mostly massive, holocrystalline, locally columnar, and as thick as $70 \mathrm{~m}$. Phenocrysts (along Klickitat River): 10-20\% plag (0.5-5 mm); 3\% olivine $(0.5-2 \mathrm{~mm})$, commonly in clusters; and $\sim 7 \% \mathrm{cpx}(0.5-1.5 \mathrm{~mm})$; fewer phenocrysts proximally, outside map area. Rests on unit Tcr here. For age relations with units outside map area, see Hildreth and Fierstein (1995). K-Ar ages: $69 \pm 15$ ka at scoria cone; $68 \pm 10$ ka at Klickitat River. [SP, JB, CF, WP, GB]

bgp Basalt of Spring Creek gravel pit (early Pleistocene)—Phenocryst-poor subalkaline lava flow $\left(51.5-52.4 \% \mathrm{SiO}_{2}\right)$ that extends $3 \mathrm{~km}$ along south side of upper Spring Creek. Covered proximally by younger units and eroded from canyon of Spring Creek, rendering source vent unknown. Generally massive and block jointed but deeply weathered on non-incised surfaces. Phenocrysts: sparse olivine and plag (both $0.5-1 \mathrm{~mm}$ ); still sparser fragments of plag megacrysts (as big as $13 \mathrm{~mm}$ ) and resorbed plag antecrysts $(<1 \mathrm{~mm})$. Groundmass olivine locally conspicuous. Overlies units Tcr (at gravel pit), bnl, bsu, and bta $(3,464 \pm 4 \mathrm{ka})$. Overlain by units $\mathbf{m n s}$, bc5, and bs $(1,722 \pm 5 \mathrm{ka})$. Undated. [CP, SB]

bgs Trachybasalt of Graham Spring (early Pleistocene)—Moderately phenocryst-rich lava flows and ejecta $\left(47.9-49.9 \% \mathrm{SiO}_{2}\right)$ that erupted largely at spatter Cone 4497, atop main north-south drainage divide of volcanic field, $1 \mathrm{~km}$ northeast of Sheep Butte. Effusive and fountain-fed lava flows also issued along a fissure that extends $2 \mathrm{~km}$ along divide north of cone and is discontinuously marked by accumulations of oxidized agglutinate. Lava-flow apron divides into two principal lobes, one extending $6 \mathrm{~km}$ north along west rim of White Fir Creek, another reaching $5 \mathrm{~km}$ northwest to base of McKays Butte; a subsidiary lobe of the latter branches $2 \mathrm{~km}$ southwestward. Vessey Springs emerge near margin of northwest flow lobe. Small red scoria cone just west of Graham Spring may be either an independent vent or a rootless secondary vent that developed where lava field poured most steeply down paleotopography. Lava flows are block jointed or slabby, massive or finely vesicular. Phenocrysts: $5-8 \%$ plag $(1-5 \mathrm{~mm})$ plus fragments $(5-20 \mathrm{~mm})$ of shattered plag megacrysts; $\sim 1 \%$ olivine (1-3 $\mathrm{mm}$, rarely $6 \mathrm{~mm}$ ); and sparse cpx (mostly $\sim 1 \mathrm{~mm}$ but as big as $8 \mathrm{~mm}$ ). Ejecta of vent cones are slightly more evolved than apron lavas. Distal $2 \mathrm{~km}$ tongue of northeast lobe is chemically similar but distinguishably richer in olivine (to $5 \%$ ), poorer in plag, carries dunite fragments as big as $10 \mathrm{~mm}$. Overlies units awv, mes, mvs, tvs, b36, b39, b60, bcs $(1,882 \pm 48 \mathrm{ka})$, bem, bns (1,566 $\pm 3 \mathrm{ka})$, bs $(1,722 \pm 5 \mathrm{ka})$, bsb, bsv, bwf, and $\mathbf{b m b}(2,079 \pm 4 \mathrm{ka})$. Overlain by units bcp and bsn $(1,479 \pm 3 \mathrm{ka}) \cdot{ }^{40} \mathrm{Ar} /{ }^{39} \mathrm{Ar}$ age: $1,531 \pm 5 \mathrm{ka}$. [HB, MB, SB, CP]

bhb1, Trachybasalt of Hagerty Butte (early Pleistocene) - Shield of basaltic lava flows (48.0-49.4\% bhb2, $\quad \mathrm{SiO}_{2}$ ) that erupted beneath the site of 130-m-high, 1-km-wide Hagerty Butte scoria cone, bhb3, which was built after radial outflow of shield lavas. Earliest flows (bhb1) are unusually bhb4 varied in phenocryst contents and proportions; most have 5-10\% total crystals with olivine dominant, but some distal domains contain $15-20 \%$ with $\mathrm{cpx} \geq \mathrm{olivine.} \mathrm{Most} \mathrm{olivine} \mathrm{is} 1-2$ $\mathrm{mm}$ but commonly as big as $4 \mathrm{~mm}$ and rarely $5-10 \mathrm{~mm}$. Cpx is typically $1-2 \mathrm{~mm}$ where sparse but 5-10 $\mathrm{mm}$ where abundant. Plag is usually subordinate and 1-4 $\mathrm{mm}$ long, but fragments of plag megacrysts are as big as $15 \mathrm{~mm}$. Lava flows of this subunit extend $4 \mathrm{~km}$ west along north side of Summit Creek. A later sequence of olivine-rich lava flows (bhb2) extends $2-3 \mathrm{~km}$ radially and dominates surface exposure on shield; it contains abundant tiny olivine (mostly $0.2-0.5 \mathrm{~mm}$ but as big as $1 \mathrm{~mm}$ ), along with sparse $1-\mathrm{mm}$ phenocrysts of plag and cpx and shattered megacryst fragments of both. Most lava flows erupted from a vent beneath later site of Hagerty Butte but also from site of adjacent 90-m-high, 800$\mathrm{m}$-wide scoria cone that banks against northwest side of Hagerty Butte. Construction of Hagerty Butte Cone was penultimate eruptive stage (bhb3) and northwestern cone the final eruptive stage (bhb4). Scoria cones consist of red and black cinders, agglutinate, and dense to vesicular bombs and blocks as big as $70 \mathrm{~cm}$. Of 10 samples analyzed, scoria from cones have lower $\mathrm{MgO}$ than any lava flows, and final cone (bhb4) has lowest $\mathrm{MgO}$ content 
of whole sequence. Shield flows are younger than all contiguous units except unit bfc $(681 \pm 2 \mathrm{ka}) .{ }^{40} \mathrm{Ar} /{ }^{39} \mathrm{Ar}$ age: $1,276 \pm 5 \mathrm{ka} .[\mathrm{HB}, \mathrm{TB}]$

bhf Trachybasalt of Hoppers Flat (early Pleistocene or Pliocene)—Phenocryst-rich lava flows and ejecta $\left(46.7-48.4 \% \mathrm{SiO}_{2}\right)$ that erupted at site of 60 -m-high double-crested scoria cone just northeast of McKays Butte. Cone is $\sim 500 \mathrm{~m}$ wide, its southwestern crest capped by agglutinate, its northeastern end by homogenized fountain-fed lava. An adjacent lavaflow apron extends $\sim 1 \mathrm{~km}$ eastward, but more may be covered by younger unit bem. Southwesterly cinder pit exposes stratified scoria-fall deposit, largely of oxidized crystalrich lapilli but including sparse, poorly vesicular, dark-gray, crystal-rich bombs $(0.2-1 \mathrm{~m}$ across). Phenocrysts: $20-35 \%$ plag (seriate $1-10 \mathrm{~mm}$ ), plus scattered plag laths as long as $15 \mathrm{~mm}$ and $\sim 1 \%$ olivine $(0.5-2 \mathrm{~mm})$. Crystal-rich lava flows weather to knobby benches and piles of rough-surfaced rounded joint blocks. A vertical dike (shown as red line), 2-3 m thick and equally crystal rich, strikes east up west side of cone to saddle between crests. West slope of cone (just north of dike) is strewn with red scoria $(1-40 \mathrm{~cm})$ that range from crystal rich to crystal poor; latter are chemically similar to the crystal-rich products that otherwise dominate. Base not exposed. Contact with nearby unit bmb wholly covered by alluvial flat. Overlain by unit bem. Undated. [MB]

bhs Trachybasalt of Hog Swamp (early Pleistocene)—Phenocryst-poor lava flow (49.0-49.3\% $\mathrm{SiO}_{2}$ ) forming a 1-km-wide plateau that extends for $2.5 \mathrm{~km}$, beyond Hog Swamp to rim of Brush Creek canyon. Source vent buried by younger units to east. Massive joint blocks and slabs crop out as ledges or as rounded weathered boulders in thick loessic soil. Phenocrysts: $\sim 1 \%$ each of olivine and plag (both $\leq 1 \mathrm{~mm}$ ), as well as sparse fragments locally of broken megacrysts of cpx, olivine, and plag (each 5-10 mm). Overlies units bmb $(2,079 \pm 5 \mathrm{ka})$ and b65. Overlain by unit bnb (1,328 2 ka). Undated. [TB]

bht Trachybasalt at Tepee Creek headwaters (early Pleistocene or Pliocene)—Plagioclase-rich lava knob $\left(48.5 \% \mathrm{SiO}_{2}\right)$ exposed as 200 - by 250 -m window through ejecta of unit b85 on northwest slope of scoria Cone 3985, $3 \mathrm{~km}$ north-northeast of Simon Butte. Outcrops on rugged knob are bold ledges, disintegrating to piles of rounded rough-surfaced nonvesicular blocks ( $1-5 \mathrm{~m}$ across); total relief $\sim 20 \mathrm{~m}$. No evidence that knob is plug or dike.

Phenocrysts: $30-40 \%$ plag (mostly $2-7 \mathrm{~mm}$, but as big as $20 \mathrm{~mm}$ ) and sparse 1-mm olivine. Base not exposed. Draped and surrounded by ejecta of unit b85, which alone is in contact with it. Undated. [MB]

bhw Basalt at White Fir Creek headwaters (early Pleistocene or Pliocene)—Moderately porphyritic lava flow $\left(48.1 \% \mathrm{SiO}_{2}\right)$ forming an isolated 500 - by 600 -m window that caps a low-relief hill separating North Fork Logy Creek from headwaters of White Fir Creek. Poorly exposed lava flow crops out at southwest toe of Smith Butte, largely as massive joint blocks through soil and colluvium. A second exposure is a small window through unit mws $\sim 1 \mathrm{~km}$ farther northwest on ridge west of White Fir Creek. Source vent unknown; possibly buried by Smith Butte. Phenocrysts: 5\% olivine (1-8 mm), 2-3\% plag (1-10 mm), and sparse cpx (1-8 mm); irregular distribution of fragments of plag and olivine megacrysts imparts local variations to apparent crystal cargo. At its north edge, overlies small poorly exposed window of moderately phenocryst-rich basalt that may be part of unit bld. Overlain by units bnw, bs $(1,722 \pm 5 \mathrm{ka})$, and $\mathbf{m w s}$. Undated. [SB]

bix Basalt of IXL Crossing Road (early Pleistocene or Pliocene)—Phenocryst-poor lava flows (48.1-48.7\% $\mathrm{SiO}_{2}$ ) that crop out as 1-km-wide, north-south belt $\sim 3 \mathrm{~km}$ long, along west rim of upper White Creek, at southeast margin of Signal Peak. Line of hills and ridges consists of massive, fine-grained, mottled, aphyric lava flows. Sparse oxidized cinders at north end suggest fissure vent, now largely reduced to dense agglutinate. Unit also crops out $\sim 1 \mathrm{~km}$ farther downstream as 1-km-long strip along west wall of White Creek gorge. Phenocrysts: virtually none; $1-\mathrm{mm}$ olivine or plag grains very rare. Overlies units Tcr, $\mathbf{m s k}(3,685 \pm 143$ ka), bjs, blo, and b84. Undated. [PB]

bjb Basalt of Jungle Butte (early Pleistocene)—Olivine-rich lava flows (50.1-52.4\% $\mathrm{SiO}_{2}$ ) of 6-km-wide Jungle Butte Shield Volcano. Thickness of non-incised central area of shield no doubt exceeds the 180-m-thick maximum exposure on east rim of Klickitat River gorge (in adjacent Jungle Butte quadrangle). Flows are numerous but poorly exposed, deeply weathered, and mantled by thick loessic soil and rubbly colluvium with rounded corestones. Generally holocrystalline, massive or vesicular, not diktytaxitic. Phenocrysts: wide range in 
olivine $(0.5-3 \mathrm{~mm})$ content, from $\sim 5 \%$ to as much as $16 \%$, many in clusters; phenocrystic plag is rare, but plag microphenocrysts occur sparsely in clots with olivine and groundmass plag is conspicuous, especially in weathered rocks. Younger than all contiguous units; rests principally on unit $\mathbf{T c r}$, and also overlies units bdr, bpc $(3,325 \pm 23 \mathrm{ka})$, and $\mathbf{b 6 8}$. K-Ar age: $1,350 \pm 50 \mathrm{ka}$ (K. Uto, written commun., 2008; appendix B). [SP, OF, JB, G]

bjs Trachybasalt of Jungle Spring (Pliocene) - Aphyric lava flows (47.5-48.5\% $\mathrm{SiO}_{2}$ ) confined to a 7-km-long east-west strip (1-1.5 km wide) between Signal Peak and Peavine Ridge Anticline. Apparently flowed both east and west from Hill 4202, but no evidence for a vent was observed there, neither oxidation nor agglutinate. Source vent is thus inferred to be buried by Signal Peak (unit msk). As throughout unit, outcrops on Hill 4202 are slabby or block jointed, sparsely vesicular, massive basalt that weathers pale gray. Outlier northwest of Surveyors Creek is remnant of a single flow $>30 \mathrm{~m}$ thick that ponded in a paleovalley and developed horizontal, inclined, and vertical columns. Phenocrysts: none, but rare fragments of plag megacrysts are as big as $5 \mathrm{~mm}$. Fine groundmass contains traces of tiny olivine and plag microlites that are commonly aligned. Overlies units Tcr and msc. Overlain by units msk (3,685 $143 \mathrm{ka})$ and bix; relation with unit blo is uncertain. Unit may have been elevated and tilted by steepening of Peavine Ridge Anticline. Undated. [SP, PB]

bkb Trachybasalt of Kaiser Butte (middle Pleistocene)-Small shield of phenocryst-poor lava flows (47.8-49.0\% $\mathrm{SiO}_{2}$ ), capped by 110-m-high scoria cone $2 \mathrm{~km}$ west of Kaiser Butte Guard Station, atop basement anticline that forms ridgecrest of Simcoe Mountains. Most lava flows extend north and northwestward to Cedar Creek. Surfaces are poorly exposed, generally scoriaceous rubble in thick loessic soil and only locally in block jointed ledges and slabs. Phenocrysts: in lava flows, sparse tiny olivine (rarely as big as $0.5-1 \mathrm{~mm}$ ) and sparse plag (1-4 mm), along with scattered fragments of plag megacrysts $(5-10 \mathrm{~mm})$. Scoria blocks on cone have more crystals $-5-8 \%$ plag $(1-6 \mathrm{~mm})$ and $1-2 \%$ tiny olivine. Rests on unit Tcr. Overlain by units bcd, bfc ( $681 \pm 2 \mathrm{ka})$, and bps. K-Ar age: $688 \pm 25 \mathrm{ka}$ (K. Uto, written commun., 2008; appendix B). [HB, TB, WPB]

bkc Trachybasalt of Kusshi Creek (early Pleistocene or Pliocene) - Phenocryst-poor lava flows (48.3-49.8\% $\mathrm{SiO}_{2}$ ) capping 1-km-wide plateau on divide between South Fork Kusshi Creek and Wilson Charley Canyon. Vent not identified, presumed buried far to west. Steep southern nose (>30 m thick) of main plateau exposure fills paleochannel cut in unit Tcr near floor of upper Wilson Charley Canyon, suggesting considerably greater extent prior to erosion, as does remnant outliers on rim just south of canyon. Surface of lava plateau is a meadow strewn with massive to vesicular blocks, deeply weathered and overlain by thick soil and colluvium. Phenocrysts: $1-3 \%$ each of plag and olivine (both $\sim 1 \mathrm{~mm}$ ) and sparse cpx (including rare megacrysts as big as $10 \mathrm{~mm}$ ). Also contains sparse fragments of microgabbro to $10 \mathrm{~mm}$. Overlies units Tcr, bww, rkc, and small remnants of units $\mathbf{m s r}$ $(3,465 \pm 4 \mathrm{ka})$ and bwc at north end of plateau. Undated. [LCSW]

bkl Trachybasalt of Klose Butte (early Pleistocene) - Aphyric lava flows and ejecta (47.1-48.6\% $\mathrm{SiO}_{2}$ ) of Klose Butte Shield volcano and capping 110-m-high scoria cone. Heavily mantled by thick loess, poorly exposed and deeply weathered lava flows extend radially, as far as $3.5 \mathrm{~km}$ southward along west side of White Creek gorge and as far as $5 \mathrm{~km}$ southwest to Elk Creek. Lava flows, bombs, and scoria are aphyric with no microphenocrysts larger than $0.3 \mathrm{~mm}$. Rock tends to weather punky and soft. Granular groundmass is generally finely vesicular and contains sparse to abundant tiny olivine grains $(0.1-0.3 \mathrm{~mm})$. Discrete plagioclase microlites (many elongate) are conspicuous, even diagnostic of the unit, especially in weathered rocks. Rare fragments (to $8 \mathrm{~mm}$ ) of plag megacrysts occur locally. Overlies units bop, bpc $(3,325 \pm 23 \mathrm{ka})$, and btb $(3,262 \pm 5 \mathrm{ka})$. Overlain by unit boh (981 $\pm 14 \mathrm{ka}) .{ }^{40} \mathrm{Ar} /{ }^{39} \mathrm{Ar}$ ages: $1,748 \pm 5 \mathrm{ka}$, on apron just south of scoria cone; $1,740 \pm 2 \mathrm{ka}$, at southwestern limit. [OF, TB]

blc Basalt of Logy Creek confluence (early Pleistocene)—Olivine-rich basaltic lava flow $\left(47.9 \% \mathrm{SiO}_{2} ; 11 \% \mathrm{MgO}\right)$ that forms northeast-sloping interfluve for $\sim 1 \mathrm{~km}$ upstream from confluence of North Fork and South Fork Logy Creek. Massive, fairly crystal-rich lava flow crops out as streambank ledges and joint blocks through loessic soil. Phenocrysts: 5-8\% olivine (1-2 mm), many in clusters; sparse plag $(\leq 1 \mathrm{~mm})$ and sparse cpx $(\sim 1 \mathrm{~mm})$, both present at $<1 \%$ abundance level. Base not exposed. Overlain by unit bsl ( $776 \pm 2 \mathrm{ka})$, of which it may be an earlier-erupted crystal-rich affiliate. Undated. [SB, LCSW] 
Basalt and basaltic andesite of Logy Creek divide (Pliocene)-Moderately phenocryst-rich lava flows (47.4-56.0\% $\mathrm{SiO}_{2}$ ) that cap extensive crest of Simcoe Mountains Shield for $\sim 10 \mathrm{~km}$ north-south, along west rims of Lakebeds and South Fork Logy Creek. From broad north-trending crest, apron flows descend southwest into upper Bowman Creek, northward beneath Smith Butte, and westward into upper Kinney Creek. Vent presumed to have been east of Lakebeds Fault Zone, as no evidence of a vent is observed west of fault zone; vent may have been at deeply eroded Cone 5659, in which case units bld and b59 would be related or equivalent. Lava flows crop out as massive and block jointed ledges or as lowrelief weathered surfaces; flows decay into slopes strewn with rounded slabs and boulders, commonly 1-2 m across. Phenocrysts: common to abundant (3-10\%) plag (1-5 mm, rarely $8-15 \mathrm{~mm}) ; 1-5 \%$ olivine $(0.5-1 \mathrm{~mm}$, uncommonly $1-3 \mathrm{~mm})$; sparser but ubiquitous cpx (1-2 mm, rarely to $8 \mathrm{~mm})$. Also contains sparse inclusions of sugary microgabbro as big as $20 \mathrm{~mm}$. Scattered outcrops exhibit modest ranges in abundances and proportions of phenocrysts, representing numerous lava flows, generally poorly exposed; despite petrographic variations, no correlation is found between mineral content or texture and chemical composition. Most samples analyzed $(\mathrm{n}=26)$ have $47-51 \% \mathrm{SiO}_{2}$ whereas a subset of five flows, intercalated with those basalts, has $52-56 \% \mathrm{SiO}_{2}$ and defines a medium-K compositional array shared by five samples of unit $\mathbf{m s l}$ along canyon of South Fork Logy Creek. Unit bld overlies unit Tcr. Overlain by units b47, b58, bs $(1,722 \pm 5 \mathrm{ka})$, bnw, bpb, bpb', bsm, byc, bob, bfr, and blw. ${ }^{40} \mathrm{Ar} /{ }^{39} \mathrm{Ar}$ age: $3,841 \pm 14 \mathrm{ka}$ for mafic sample from base of unit, resting on unit Tcr, $1.3 \mathrm{~km}$ west of Lakebeds. ${ }^{40} \mathrm{Ar} /{ }^{39} \mathrm{Ar}$ age: $3,820 \pm 57 \mathrm{ka}$ for evolved sample high on shield southeast of Stagman Butte. [HB, SB]

bln Basalt of lower North Fork Logy Creek (Pliocene)-Moderately phenocryst-rich lava flows $\left(49.3-50.1 \% \mathrm{SiO}_{2}\right)$ that crop out as narrow swath along walls of North Fork for $3.3 \mathrm{~km}$ downstream from main road crossing at elevation 3,700 ft. Exposures are massive blockjointed ledges and knobs, including small window through unit bsl $500 \mathrm{~m}$ south of North Fork. Source vent buried beneath younger units to southwest. Phenocrysts: varied amounts (3-10\%) of plag (1-2 $\mathrm{mm}$, rarely to $5 \mathrm{~mm}$ ), may or may not exceed common olivine $(1 \mathrm{~mm})$; sparse cpx $(0.5-2 \mathrm{~mm})$. Base not exposed. Overlain by units $\mathbf{m n f}$, bs $(1,722 \pm 5 \mathrm{ka})$, and bsl (776 $2 \mathrm{ka})$. Undated. [SB]

blo Basalt of Lost Springs (Pliocene)—Megacryst-rich basaltic lava flows (48.5-48.7\% $\mathrm{SiO}_{2}$ ) exposed from beneath northeast margin of Signal Peak Shield for $12 \mathrm{~km}$ southward along White Creek drainage. Appears to have erupted farther north, beneath extensive basaltic plateau of unit blp. Northern exposures are $\sim 4,100 \mathrm{ft}$ elevation; flows extend $>8 \mathrm{~km}$ southeastward along west side of White Creek, then an additional $4 \mathrm{~km}$ southward along the floor of White Creek gorge, passing beneath younger units at $2,650 \mathrm{ft}$. Unit forms bold knobs and ledges. Crystals: Abundant cpx (mostly $2-10 \mathrm{~mm}$ but as big as $20 \mathrm{~mm}$ ), rectangular to rounded; abundant but slightly fewer olivine crystals (mostly 3-5 mm but as big as $15 \mathrm{~mm}$ ); olivine-cpx aggregates and peridotite fragments as large as $10 \mathrm{~mm}$ are also common, as are clusters of olivine and of plagioclase+olivine; fragments of broken plagioclase megacrysts as big as $15 \mathrm{~mm}$ across are common proximally but sparse or absent distally. No true phenocrysts of plagioclase. Scattered olivine microphenocrysts $(\leq 0.5 \mathrm{~mm})$ may be only crystals precipitated directly from the erupting magma. Overlies units msk ( $3,685 \pm 143 \mathrm{ka})$, bsz (3,323 $\pm 6 \mathrm{ka})$, buw, b80, and b84. Overlain by units bix, blp $(3,278 \pm 4 \mathrm{ka})$, bsr $(1,685 \pm 11 \mathrm{ka}), \mathbf{b} 94$, and $\mathbf{m} 93$. Undated. [SP, PB]

blp Trachybasalt of Lincoln Plateau (Pliocene) - Extensive shield of aphyric basaltic lava flows (49.3-51.0\% $\mathrm{SiO}_{2}$ ) erupted from fissure vent on Lincoln Plateau $\sim 3 \mathrm{~km}$ north of Signal Peak Ranger Station, just north of map area. Lava spread radially, including tongues that extend for $8 \mathrm{~km}$ southwest along both rims of Surveyors Creek and for $4 \mathrm{~km}$ southeast along White Creek-Toppenish Creek divide. Dense, fine-grained lava flows crop out as slabs and joint blocks or ledges along canyon rims; very fine plag microlites impart sheen to joint faces. Medium- to dark-gray rocks weather pale gray or tan, widely punky. Phenocrysts: none; olivine microphenocrysts $(0.1-0.4 \mathrm{~mm})$ are common. Overlies units Tcr, msk $(3,685 \pm 143 \mathrm{ka})$, blo, bsz (3,323 $\pm 6 \mathrm{ka}), \mathbf{m s c}$, and (north of map area) basalt of Panther Butte $(3,568 \pm 55 \mathrm{ka}) .{ }^{40} \mathrm{Ar} /{ }^{39} \mathrm{Ar}$ age: $3,278 \pm 9 \mathrm{ka}$. [SP, PB, CF, LHP]

bls Basalt of Logy Creek-Spring Creek divide (early Pleistocene or Pliocene)—Sparsely porphyritic subalkaline lava flow $\left(48.7 \% \mathrm{SiO}_{2}\right)$ that crops out as a pair of 500 -m-wide 
exposures banked against west side of Cone 3114. Massive block-jointed to slabby flow forms ledge along Logy Creek and low-relief rocky meadow south of Spring Creek.

Phenocrysts: $2-5 \%$ plag $(1-3 \mathrm{~mm})$ and sparse olivine $(0.5-2 \mathrm{~mm})$. Contact is obscure but may grade upward into an overlying (nearly aphyric) flow of unit bs; if so, unit may simply represent a phenocryst-enriched domain within an elsewhere crystal-poor set of flows. Overlies units b14 and bta (3,464 $\pm 4 \mathrm{ka})$. Overlain by unit bs (1,722 $\pm 5 \mathrm{ka})$. Undated. [LCSW, LCF]

blw Trachybasalt west of South Fork Logy Creek (early Pleistocene or Pliocene)—Phenocrystpoor lava flow (47.1-47.2\% $\mathrm{SiO}_{2}$ ) that caps a 3.5-km-long series of benches, 200-500 m wide, along west rim of upper South Fork Logy Creek, starting $1 \mathrm{~km}$ north of Lakebeds. North-south fault drops unit, east-side-down, to form benches along eastern slope of ridgeforming unit bld. Low-relief surface appears to be a single flow with as much as $25 \mathrm{~m}$ relief, as exposed at southeast-facing rim near its south end; elsewhere poorly exposed. Rock is massive and slabby or block jointed, but much of its surface is mantled by thick soil. Phenocrysts: generally aphyric but contains irregularly scattered plag $(1-5 \mathrm{~mm})$ and rare

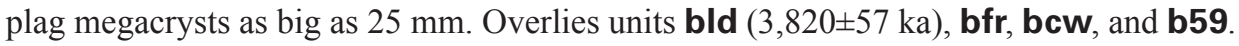
Undated. [SB]

bly Trachybasalt of Lyon Spring (early Pleistocene)—Moderately phenocryst-poor lava flows and ejecta (47.4-48.8\% $\mathrm{SiO}_{2}$ ) erupted from north-trending fissures on divide between Pole and White Creeks at southern base of Peavine Ridge Anticline. Subdued ridge of scoria and agglutinate has only $\sim 35 \mathrm{~m}$ relief and is surrounded by apron of lava flows, massive to vesicular, that extends as far as $1 \mathrm{~km}$ westward as well as southward past Lyon Spring. Locally crops out boldly as ledges and knobs. Phenocrysts: $3-5 \%$ plag (mostly $1-4 \mathrm{~mm}$, with erratically distributed plag megacryst fragments as big as $10 \mathrm{~mm}$ ); very sparse olivine (generally $\leq 1 \mathrm{~mm}$, but as big as $3 \mathrm{~mm}$ in near-vent scoria bombs). Younger than all three contiguous units - b97, bsr (1,685 $\pm 11 \mathrm{ka})$, and bwk. Near some contacts with plag-rich unit bwk, sharply bounded plag-rich domains (1-10 $\mathrm{m}$ across) are enclosed in crystal-poor bly host, and meter-scale irregular transition zones have 5-10\% plag, suggesting that the two were coeruptive magma batches. ${ }^{40} \mathrm{Ar} /{ }^{39} \mathrm{Ar}$ age: $1,697 \pm 20 \mathrm{ka}$. [PB, SP]

bmb Trachybasalt of McKays Butte (early Pleistocene) -Phenocryst-poor lava flows and ejecta (46.4-48.9\% $\mathrm{SiO}_{2}$ ) that erupted at 3-km-wide, 250-m-high scoria cone, McKays Butte. Cone is capped by agglutinate, but slopes are strewn with scoria lapilli and bombs. Lava flows are widely covered by younger units but crop out for $10 \mathrm{~km}$ along walls of Brush Creek gorge as far as its Hog Swamp tributary; a remnant $2 \mathrm{~km}$ farther downstream rims confluence of Blue and Brush Creeks. Distinctively massive, slabby to block-jointed lava flows are either aphyric or contain trace amounts of olivine $(0.5-1 \mathrm{~mm}$; rarely $2 \mathrm{~mm})$, still rarer cpx, and virtually no true phenocrysts of plag. Fragments of shattered plag megacrysts, typically $1-10 \mathrm{~mm}$ and as big as $25 \mathrm{~mm}$, are rare but widespread. Megacrysts of all three minerals, accompanied by spinel-peridotite nodules as big as $10 \mathrm{~mm}$, are anomalously common on summit of McKays Butte. Groundmass is locally studded with tiny olivine $(\leq 0.3 \mathrm{~mm})$. Rare multigrain intergrowths as big as $20 \mathrm{~mm}$ of olivine, cpx, and plag crystals can be found locally. Overlies units b60, b65, and bsh $(3,251 \pm 7 \mathrm{ka})$. Overlain by units asi, bcp, bcr $(1,513 \pm 4 \mathrm{ka})$, bem, bgs $(1,531 \pm 4 \mathrm{ka})$, bhs, bmf, bnb $(1,328 \pm 2 \mathrm{ka})$, bns $(1,566 \pm 3 \mathrm{ka})$, and probably bsi $(1,875 \pm 3 \mathrm{ka}) .{ }^{40} \mathrm{Ar} /{ }^{39} \mathrm{Ar}$ age: $2,079 \pm 6 \mathrm{ka}$. [MB, TB, PB, HB]

bmc Basalt east of Mike Coon Hillside (early Pleistocene or Pliocene)—Moderately phenocrystrich lava flows (47.9-48.9\% $\mathrm{SiO}_{2}$ ) that emerge from beneath younger units $2 \mathrm{~km}$ north of Simon Butte and crop out for $\sim 4$ km downstream along Tepee Creek, ending in a 30-m-high terminus that banked against unit Tcr at Mike Coon Hillside. Upstream exposures adjacent to Tepee Creek crop out as knobby, block-jointed surfaces largely scoured of soil cover, in contrast to flanking plateaus of younger lavas, which are mantled by loessic soil $\sim 2 \mathrm{~m}$ thick. Exposures on broad lobe downstream are massive (or less commonly slightly vesicular) and generally crop out as block-jointed ledges or rounded joint blocks in loessic soil. Phenocrysts: abundant conspicuously large plag (1-20 mm); sparse olivine and sparser cpx (both $\leq 1 \mathrm{~mm})$. Overlies unit Tcr. Overlain by units bnf $(1,533 \pm 3 \mathrm{ka})$, boc $(2,136 \pm 5 \mathrm{ka})$, and bsi $(1,875 \pm 3 \mathrm{ka})$. Undated. [MB, PB]

bmf Trachybasalt of Middle Fork Dry Creek (early Pleistocene)—Extensive lava field of phenocryst-poor olivine basalt $\left(48.9-49.2 \% \mathrm{SiO}_{2}\right)$, north and northeast of McKays Butte, 
that extends from Middle Fork Dry Creek for $7 \mathrm{~km}$ southwest to Coyote Spring, where it divides into several tongues on slopes toward Brush Creek. Thickest exposures are $\sim 25 \mathrm{~m}$, typically block jointed or slabby, massive or weakly vesicular, disintegrating into rounded joint blocks in thick soil. Rocks on plateau surface to northeast are widely vesicular but poorly exposed. Source vent probably concealed to north under unit bnf. Phenocrysts: proportions of plag, olivine, and cpx range considerably, though all three are common and olivine is almost everywhere dominant: $1-5 \%$ olivine (1-2 $\mathrm{mm}$, rarely to $4 \mathrm{~mm}) ; 1-3 \%$ plag (1-2 mm) plus irregularly scattered fragments of plag megacrysts as big as $15 \mathrm{~mm}$; rare to common cpx (1-2 mm). Overlies units asi, b00, b37, bem, b90, bmb $(2,079 \pm 5 \mathrm{ka})$, and bsi $(1,875 \pm 3 \mathrm{ka})$. Overlain by units b03 and bnf (1,533 $\pm 3 \mathrm{ka})$. Undated. [MB, CP]

bms Basalt of McCumber Spring (middle or early Pleistocene)-Moderately phenocryst-rich lava flow (49.3-50.3\% $\mathrm{SiO}_{2}$ ) at north edge of the Glenwood valley (Hildreth and Fierstein, 1995). Source vent is buried by younger flows northwest of McCumber Spring, but lava flow is continuous for $6 \mathrm{~km}$, barely entering western edge of map area, where its blocky flow-front is $\sim 10 \mathrm{~m}$ high and banked-in alluvium conceals its base. Generally poorly exposed with low relief and thick loessic soil cover. Exposed rocks are extensively crystalline, weathered, and vesicular. Phenocrysts: $11-15 \%$ plag $(0.5-3 \mathrm{~mm}) ; 5-8 \%$ olivine $(0.5-2 \mathrm{~mm})$, typically with iddingsite rims; and 1-2\% cpx (0.5-1.5 mm). Rests on units Tcr and bof (967 $\pm 4 \mathrm{ka})$. Overlain west of map area by dacite of Dry Creek (695 \pm 8 ka) (Hildreth and Fierstein, 1995). Undated. [OF, G]

bnb Trachybasalt north of Blue Creek (early Pleistocene)_Phenocryst-rich lava flows and ejecta (48.7-49.9\% $\mathrm{SiO}_{2}$ ) that erupted along a 2-km-long north-trending fissure between Blue and Sheep Creeks that built a spatter-and-lava ridge capped by three scoria cones. Lava-flow apron, typically massive and block jointed, is 2-3 km wide proximally, surrounds older Cone 3432 (unit $\mathbf{m n b}$ ), and extends in two lobes as far as $9 \mathrm{~km}$ westward to rim of Brush Creek canyon. Small scoria cones, each 35-65 m high, consist of loose cinders and vesicular blocks, variably oxidized and agglutinated only locally. Phenocrysts: $\sim 10 \%$ plag (1-3 mm) plus scattered fragments of shattered plag megacrysts $(5-15 \mathrm{~mm})$; abundant $\mathrm{cpx}(1-7 \mathrm{~mm})$; and abundant subordinate olivine (1-6 mm), which is commonly in clusters. Olivine is (on average) smaller and proportionally sparser among phenocrysts of scoria cones relative to those of lava flows. Flows also locally contain sparse angular inclusions of sugary olivinecpx-plag microgabbro as big as $50 \mathrm{~mm}$. Overlies units $\mathbf{m n b}, \mathbf{b 3 4}$, b65, bbl (1687 $\pm 5 \mathrm{ka})$, bhs, bmb (2,079 $\pm 5 \mathrm{ka})$, bns (1,566 $\pm 3 \mathrm{ka})$, bsh (3,251 $\pm 7 \mathrm{ka})$, and bub. Overlain by units bhb $(1,276 \pm 4 \mathrm{ka})$, bnt, and bus. ${ }^{40} \mathrm{Ar} /{ }^{39} \mathrm{Ar}$ age: $1,328 \pm 2 \mathrm{ka}$. [HB, TB]

bnf Trachybasalt of North Fork Dry Creek (early Pleistocene)-Moderately phenocryst-rich lava flows and ejecta $\left(47.4-48.7 \% \mathrm{SiO}_{2}\right)$ that erupted at site of $80-\mathrm{m}$-high scoria Cone 3925 , $1 \mathrm{~km}$ wide, centered $3 \mathrm{~km}$ northeast of Simon Butte. Major lava-flow apron divides into two lobes: one extends $4 \mathrm{~km}$ west to Snow and Tepee Creeks; the other extends $10 \mathrm{~km}$ east, spreading out as broad plateau between Toppenish Ridge and Camas Patch and reaching as far as Wall Canyon rim of Dry Creek. Cone is capped by nubbins and block-jointed sheets of dense to blobby agglutinate. Lava flows are generally block jointed and massive but commonly weakly vesicular. Exposure is poor on forested low-relief plateaus where surfaces are covered by thick loessic soil and protruding blocks tend to be weathered and vesicular. Despite wide extent, thickness exposed rarely exceeds $15 \mathrm{~m}$ and is only 7-10 $\mathrm{m}$ on east-distal canyon rims. Phenocrysts: $5-8 \%$ plag $(1-8 \mathrm{~mm})$ plus common fragments $(10-25$ $\mathrm{mm}$ ) of plag megacrysts; common olivine (1-6 mm); sparse cpx (1-5 mm). Overlies units Tcr, asi, b03, b37, b85, bcs $(1,882 \pm 48 \mathrm{ka})$, bmc, bmf, b90, boc $(2,136 \pm 5 \mathrm{ka})$, bsf $(2,060 \pm 10 \mathrm{ka})$, bsi $(1,875 \pm 3 \mathrm{ka})$, bth, and bts. No contiguous units are younger. ${ }^{40} \mathrm{Ar} /{ }^{39} \mathrm{Ar}$ age: $1,533 \pm 3 \mathrm{ka}$. [MB, CP]

bnk Basalt north of Kinney Creek (middle or early Pleistocene)—Phenocryst-rich lava flows $\left(47.1-47.4 \% \mathrm{SiO}_{2}\right), \sim 1 \mathrm{~km}$ wide, that extend from fissure vents at Hills 4291 and 4005 for $\sim 5 \mathrm{~km}$ westward between Twentyfive Mile and Kinney Creeks to a terminus near their confluences with Summit Creek. Hill 4005 is capped by agglutinate and sparse scoria as big as $20 \mathrm{~cm}$. Hill 4291 is also vent for crystal-poor unit bws, but its south slope is cut by a $10-\mathrm{m}$-wide degraded rib of densely blobby layered agglutinate, remains of a fissure vent, that decays into rounded crystal-rich boulders. Lava tongue forms massive blockjointed knobs and benches or weathers into rounded boulders in thick soil. Phenocrysts: 
abundant plag (1-15 mm), abundant olivine (1-5 mm), and common cpx (1-3 mm). Plag generally dominates, but a few domains are richer in cpx, and olivine predominant in some proximal exposures; despite such variation, bulk composition varies little. Sparse fragments of microgabbro as big as $10 \mathrm{~mm}$ were observed in a few places. Overlies units b34, bld $(3,841 \pm 14 \mathrm{ka})$, bnt, bsm, bws, and byc; banks against bhb (1,276 $\pm 4 \mathrm{ka})$. Overlain by unit bfc (681 $\pm 2 \mathrm{ka})$. Undated. [HB]

bnl Basalt of North Fork Logy Creek (Pliocene) - Moderately phenocryst-rich lava flows (47.5$49.0 \% \mathrm{SiO}_{2}$ ) that emerge from beneath younger units $\sim 1 \mathrm{~km}$ east of Smith Butte and extend for $3 \mathrm{~km}$ northeastward on both rims of North Fork Logy Creek. North and northeast of main exposure, four small windows of petrographically similar (but chemically somewhat varied) flows are assigned to unit $\mathbf{b n l}$, suggesting that it extends at least $4 \mathrm{~km}$ farther in subsurface. Source vent is buried by younger units of Castle Rock Shield south of Smith Butte. Flows crop out as massive block-jointed ledges and knobs, their greatest total thickness $\sim 30 \mathrm{~m}$. Phenocrysts: $3-8 \%$ plag $(1-5 \mathrm{~mm}$, rarely to $10 \mathrm{~mm})$; sparse to common olivine ( 1 $\mathrm{mm}$, rarely to $4 \mathrm{~mm})$. Overlies unit $\mathbf{m n f}$. Overlain by units bfr, bgp, bs $(1,722 \pm 5 \mathrm{ka})$, bsl (776 $\pm 2 \mathrm{ka})$, and $\mathbf{~ m s l}(3,550 \pm 4 \mathrm{ka})$. Undated. [SB]

bns, Trachybasalt north of Sheep Creek (early Pleistocene)—Moderately phenocryst-rich lava bns' flows and ejecta (47.7-49.5\% $\left.\mathrm{SiO}_{2}\right)$ that erupted from 50-m-high scoria Cone 3644, $2 \mathrm{~km}$ southwest of Vessey Springs. Lava flows divide around and surround 90-m-high scoria Cone 3540+ (subunit bns', which appears to represent a compositionally more evolved, early batch of petrographically similar magma). Northern tongue extends $6 \mathrm{~km}$ westward between Sheep and Brush Creeks as far as their confluence. Southern tongue extends $3.5 \mathrm{~km}$ southwest to flow front at Sheep Creek. Lava flows are massive and block jointed, with vesicular zones rarely preserved. Westernmost flow front is $\sim 30 \mathrm{~m}$ high, and southern flow is locally as thick as $\sim 70 \mathrm{~m}$. Phenocrysts: $\sim 10 \%$ plag ( $1-6 \mathrm{~mm}$ long) plus sparse plag megacrysts as big as $20 \mathrm{~mm} ; 1-2 \%$ olivine (1-5 mm; commonly in clusters), and erratic but generally sparser amounts of cpx (1-3 mm) and olivine-cpx clots. Rare inclusions of cpx-olivine-plag microgabbro $(10-30 \mathrm{~mm})$ are also present. Southern tongue tends to have slightly more and coarser phenocrysts than the northern one. Overlies units bmb $(2,079 \pm 5 \mathrm{ka})$ and $\mathbf{m v s}$. Overlain by units bgs $(1,531 \pm 4 \mathrm{ka}), \mathbf{b c p}$, bcr $(1,513 \pm 4 \mathrm{ka}), \mathbf{b s b}$, bus, and bnb (1,328 $2 \mathrm{ka})$. Chemically, petrographically, and morphologically similar to adjacent lava-flow complex of unit bnb, though they clearly issued from different vents. ${ }^{40} \mathrm{Ar} /{ }^{39} \mathrm{Ar}$ age: $1,566 \pm 3 \mathrm{ka}$. [HB, TB, MB]

bnt Trachybasalt north of Twentyfive Mile Creek (early Pleistocene)-Moderately phenocrystrich lava flows and ejecta $\left(47.8-48.8 \% \mathrm{SiO}_{2}\right)$ erupted from spatter Vent $4900, \sim 2.5 \mathrm{~km}$ northwest of Stagman Butte. Vent is marked by brick-red, stratified, tack-welded agglutinate that grades out into a lava-flow apron that descends $6 \mathrm{~km}$ westward to headwaters of Blue Creek. Vent is overlapped by younger phenocryst-poor lava flows and ejecta of adjacent Stag trig (locally named "Stag" triangulation station near top of scoria Cone 4889, the vent for unit bst). Lava flows are generally massive and block jointed or slabby, rarely vesicular, and decay into rounded boulders in thick soil and colluvium. Phenocrysts: $5-10 \%$ plag $(0.5-5 \mathrm{~mm}$ long) plus common fragments $(10-30 \mathrm{~mm})$ of plag megacrysts; $1-3 \%$ olivine $(\leq 1 \mathrm{~mm})$; and sparse to rare cpx $(1-2 \mathrm{~mm})$. Also contains sparse inclusions $(10-30 \mathrm{~mm})$ of sugary microgabbro. Overlies units bsm $(2,056 \pm 25 \mathrm{ka})$, bub, but, bws, b34, and banks

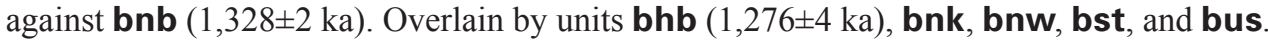
Undated. [HB]

bnw Trachybasalt northwest of Stagman Butte (early Pleistocene)—Variably porphyritic lava flows and ejecta $\left(47.2-49.0 \% \mathrm{SiO}_{2}\right)$ erupted at spatter-and-scoria Cone $4860+$, centered $2 \mathrm{~km}$ north-northwest of Stagman Butte and $1 \mathrm{~km}$ east of Stag trig. Lava-flow apron, block jointed and widely vesicular, extends $1 \mathrm{~km}$ southwest and $2 \mathrm{~km}$ northeast. Near-vent agglutinate is oxidized and either weakly tack welded or densely welded and boldly knobby; eroded agglutinate crags are as high as $7 \mathrm{~m}$. Phenocrysts: unusually varied amounts $(2-8 \%)$ of plag $(1-8 \mathrm{~mm})$, many of which are fragments of megacrysts as big as $20 \mathrm{~mm}$ when unbroken. Euhedral plag phenocrysts $(1-3 \mathrm{~mm})$ are sparse, and some occur in clots with 1-mm olivine and cpx, which are also sparse. Sugary microgabbro inclusions (10-30 mm) are present but rare. Were it not for feldspar fragments, rock would be crystal poor; irregularly scattered plag and rarity of mafic phenocrysts are characteristic of unit. Overlies 
all contiguous volcanic units-mws, bhw, bld $(3,820 \pm 57 \mathrm{ka})$, bnt, bs $(1,722 \pm 5 \mathrm{ka})$, bsm $(2,056 \pm 25 \mathrm{ka})$, bst, and but. Undated. [HB, SB]

bob Basalt of Old Indian Treaty Boundary (Pliocene)—Phenocryst-poor lava flow (46.5-46.9\% $\mathrm{SiO}_{2}$ ) exposed as $1.5-\mathrm{km}$-long swath (100-300 m wide) along northeast side of Stagman Butte. Crops out as massive joint blocks on continuous slope with few ledges. Phenocrysts: sparse olivine (1-3 mm; some in clusters) and rare plag $(0.5-2 \mathrm{~mm})$. Fairly primitive composition with $>9 \mathrm{wt} \% \mathrm{MgO}$. Vent buried by flows of unit bld higher on Simcoe Shield to southeast. Base not exposed. Overlain by units bsm $(2,056 \pm 25 \mathrm{ka})$ and bld $(3,841 \pm 14 \mathrm{ka})$. Undated. [SB]

boc Trachybasalt of Olney Creek (early Pleistocene)—Phenocryst-poor lava flows (47.3-49.7\% $\mathrm{SiO}_{2}$ ) that form a moderately dissected plateau stretching $13 \mathrm{~km}$ east from headwaters of White Deer Creek as far as Camp Creek. Gently north-sloping plateau, 1-3 km wide, extends from north edge of anticline to south rims of White Deer and Toppenish Creek canyons. Total thickness typically $20-40 \mathrm{~m}$, thickening locally to $75 \mathrm{~m}$ at some canyon rims. Source vent not present south of canyons; in common with lithologically and chemically similar units bwt and bcc, source probably lies north of Toppenish Creek (beyond map area). Outcrops are massive, block jointed, slabby, or hackly, and commonly mottled, weathering on stable surfaces into rounded blocks in thick loessic soil. Phenocrysts: commonly none; sparse olivine microphenocrysts are widespread, as are scattered fragments $(1-10 \mathrm{~mm})$ of plag megacrysts; rare phenocrysts of olivine $(\sim 1 \mathrm{~mm})$ and plag $(0.5-3 \mathrm{~mm})$ can be found by diligent search. Overlies units Tcr, bdl, bmc, btp, and bwh. Overlain by units beo, bnf, bor, and bth. ${ }^{40} \mathrm{Ar} /{ }^{39} \mathrm{Ar}$ age: $2,136 \pm 5 \mathrm{ka}$. [MB, PB]

bof Basalt of Outlet Falls (early Pleistocene) - Stacks of many thin diktytaxitic lava flows (47.5-50.0\% $\left.\mathrm{SiO}_{2}\right)$ of low- $\mathrm{K}$ tholeiiitic basalt $\left(\mathrm{K}_{2} \mathrm{O}=0.16\right.$ to $\left.0.44 \mathrm{wt} \%\right)$, widely preserved as intracanyon remnants along both walls of Klickitat River and lower White Creek and capping adjacent plateaus traversed by Outlet, Bear, and Trout Creeks as well as bench at Schafer Pocket. Local sequences contain as many as 25-30 flows that, taken together, are as thick as $125 \mathrm{~m}$ at Schafer Pocket and more than $150 \mathrm{~m}$ thick along Klickitat River gorge. Stack thickness varies strongly according to whether preserved canyon-filling section had been axial, banked against sloping sidewalls, or overbank. Remnants survive on Klickitat River canyon walls for at least $15 \mathrm{~km}$ downstream from edge of map area, at least as far as confluence of Dead Canyon. Source vent, concealed by younger units, lies upstream in Klickitat River drainage system, north or west of its confluence with Bacon Creek (Hildreth and Fierstein, 1995). Lava flows that descended Klickitat gorge backfilled up White Creek tributary to an elevation as high as $550 \mathrm{~m}(1,800 \mathrm{ft})$. Most flows are 1-5 m thick, vesicular, holocrystalline, and diktytaxitic, although a few thicker $(>10 \mathrm{~m})$ flows have massive interiors. Vesicle sheets and cylinders are widespread. Vertical jointing is ubiquitous but columnar only locally. Vertical joints locally transect two or three flows, suggesting that some rapidly emplaced sequences cooled as a unit. Gently beveled unconformities within stacks of flows might represent modest erosion during time breaks or, alternatively, drainaway of fluid lava. Most flows have microphenocrysts of olivine and plag; only a few have free crystals larger than $0.5 \mathrm{~mm}$, although rare olivine phenocrysts $(0.5-1.5 \mathrm{~mm})$ do occur, and some flows contain 10-mm starburst clusters of intergrown olivine $(\leq 1-\mathrm{mm})$ and plagioclase $(0.5-2 \mathrm{~mm})$. Overlain by units apc $(120 \pm 5 \mathrm{ka})$ and $\mathbf{b m s}$; younger than all other contiguous units. K-Ar age: $775 \pm 114 \mathrm{ka}$ (Hildreth and Lanphere, 1994). ${ }^{40} \mathrm{Ar} /{ }^{39} \mathrm{Ar}$ age: $967 \pm 4$ ka. [OF, TB, G, DC, GM]

boh Trachybasalt of Oak Hill (early Pleistocene)—Phenocryst-poor lava flows (47.1-47.7\% $\mathrm{SiO}_{2}$ ) of 9-km-wide Oak Hill Shield Volcano, capped by 60-m-high scoria cone, on divide between White and Trout Creeks. Lava flows extend $6 \mathrm{~km}$ southward adjacent to White Creek and $7 \mathrm{~km}$ southwest to Elk and Trout Creeks. Most exposures are massive joint blocks and slabs, some sparsely vesicular. Some flows are aphyric, but most contain $\sim 1 \%$ olivine $(1-2 \mathrm{~mm})$. Olivine megacrysts as big as $8 \mathrm{~mm}$ and clusters of 1-mm olivine occur sparsely. Rarely, plagioclase (as long as $1 \mathrm{~mm}$ ) and cpx (1-8 $\mathrm{mm}$ ) are present, though both are typically absent. Overlain by unit b10. Younger than all other contiguous units, including unit bw $(1,885 \pm 5 \mathrm{ka}) .{ }^{40} \mathrm{Ar} /{ }^{39} \mathrm{Ar}$ age: $981 \pm 14 \mathrm{ka}$. [PB, TB, SP, OF]

bop Trachybasalt of Old Peavine Ridge Road (early Pleistocene) - Aphyric lava flows (49.4$49.6 \% \mathrm{SiO}_{2}$ ) exposed only in low saddle separating Klose Butte and Oak Hill Shields. 
Rocks are pale or medium gray, massive, fine grained, and crop out through thick loessic soil as rounded blocks and slabs. Vent is probably buried by younger flows of Oak Hill Shield. Phenocrysts: none. Microlites and microphenocrysts are absent or macroscopically inconspicuous, in contrast to adjacent aphyric unit bkl. Unit is chemically far more evolved than nearby aphyric unit bw $(1,885 \pm 5 \mathrm{ka})$. Base not exposed. Overlain by units bkl $(1,748 \pm 5 \mathrm{ka})$ and boh ( $981 \pm 14 \mathrm{ka})$. Undated. [TB, OF]

bor Trachybasalt of Oak Spring Road (early Pleistocene) - Phenocryst-poor lava flows and ejecta $\left(48.0-48.4 \% \mathrm{SiO}_{2}\right)$ erupted at site of scoria/spatter Cone $3560+$ between headwaters of Olney and Camp Creeks at north margin of Toppenish Ridge Anticline. This relatively crystal poor unit represents early phase of cone activity, succeeded by spatter and lava flows of plagioclase-rich unit beo. Scoria lapilli and bombs peripheral to summit (which is capped by agglutinate of unit beo) are poor in olivine and plag, variably oxidized, and grade to agglutinate and fountain-fed flows. Lava flows of apron are massive or weakly vesicular and extend $2 \mathrm{~km}$ north and $1 \mathrm{~km}$ southwest of cone. Southwest sector may have been slightly elevated by post-eruptive steepening of anticline. Phenocrysts: $1-2 \%$ olivine $(0.5-1 \mathrm{~mm})$; sparse 1-mm plag, plus rare shattered plag megacrysts as big as $8 \mathrm{~mm}$; very rare $1-\mathrm{mm} \mathrm{cpx}$. Overlies units Tcr, boc $(2,136 \pm 5 \mathrm{ka})$, and bth. Overlain by unit beo. Undated. [MB]

bos Basalt of upper Summit Creek (Pliocene) - Moderately phenocryst-rich lava flows (48.0 $48.5 \% \mathrm{SiO}_{2}$ ) that drape steep paleotopography developed on Miocene basement rocks (unit Tcr) between Kinney and Summit Creeks, $\sim 3 \mathrm{~km}$ west of Potato Butte. Massive to vesicular flows are generally block jointed, deeply weathered, and have $\sim 185 \mathrm{~m}$ of exposed draping relief but appear to be no thicker than $30 \mathrm{~m}$. Phenocrysts: abundant small olivine $(0.5-1 \mathrm{~mm})$; subordinate but common plag $(1-5 \mathrm{~mm})$; sparse cpx $(\sim 1 \mathrm{~mm})$. Locally oldest Simcoe unit in map area rests on unit Tcr. Overlain by units bfc $(681 \pm 2 \mathrm{ka})$, byc, and bpb $(822 \pm 3 \mathrm{ka})$. Similarly distinctive lava flows, rich in olivine and $\mathrm{MgO}$ and unusually low in $\mathrm{Al}_{2} \mathrm{O}_{3}$, were noted as limited exposures (not shown on map) beneath or within multi-flow unit bld $(3,841 \pm 14 \mathrm{ka})$, just south of Lakebeds and within $\sim 1 \mathrm{~km}$ radially of Yeackel Camp. Undated. [HB]

bot Basalt of Twentyfive Mile Creek (Pliocene)-Moderately phenocryst-rich lava $\left(50.2 \% \mathrm{SiO}_{2}\right)$ exposed as small window on north bank of Twentyfive Mile Creek at 3,400 ft elevation, $3 \mathrm{~km}$ east of Hagerty Butte. Massive blocks and slabs contain 7-10\% olivine (1-3 mm), sparse plag (laths 2-4 mm long), and rare cpx. No unequivocal outcrop was recognized; blocks and slabs are loose on slope and some were bulldozed for logging-road construction, but most are lichen-covered and unscarred, unlikely to have been transported. No outcrops of this unusual rock have been identified nearby, but lithologically similar olivine-rich flows occur in unit bos ( $2 \mathrm{~km}$ south) and within unit bld (3-4 km east). Base not exposed. Overlain by unit bnk. Undated. [HB]

bpb, Trachybasalt of Potato Butte (early Pleistocene)—Aphyric lava flows and ejecta (48.6-50.4\% bpb' $\mathrm{SiO}_{2}$ ) erupted at prominent skyline knob (at 5,200 ft elevation) atop Simcoe Mountains Anticline, $\sim 4 \mathrm{~km}$ west of crest of Castle Rock Shield. Eroded knob, Potato Butte, is spatterand-scoria cone marked by spindle bombs, scoria, and oxidized agglutinate, which is crudely stratified, weakly welded, and eroded into ragged knobs and crags with 2-8 m local relief. Cone grades out into apron of lava flows that descend steep slopes, $3 \mathrm{~km}$ southward to Bowman Creek and as far as $4.5 \mathrm{~km}$ westward along upper Summit Creek. Outcrops are mostly massive ledges, joint blocks, and slabs that contain either no phenocrysts or only trace amounts of spinel-bearing olivine $(0.5-2 \mathrm{~mm})$ or still rarer plag $(<1 \mathrm{~mm})$. Weathering accentuates plag microlites in groundmass. Lavas of subunit bp b' $\left(48.3 \% \mathrm{SiO}_{2}\right)$, which extends $\sim 500 \mathrm{~m}$ (exclusively eastward) from vent, differ in containing sparse plag (1-2 mm), rare olivine $(\leq 1 \mathrm{~mm})$, and rare plag megacrysts $(5-10 \mathrm{~mm})$; proximal parts of the subunit are fountain-fed rheomorphic agglutinate, inhomogeneously knobbly or lumpy. Overlies units Tcr, bld ( $3,841 \pm 14 \mathrm{ka})$, bos, and bwg. Overlain by units bfc $(681 \pm 2 \mathrm{ka})$, byc, and probably by units bbc and b58. ${ }^{40} \mathrm{Ar}{ }^{39} \mathrm{Ar}$ age: $822 \pm 3 \mathrm{ka}$. [HB, SB, WPB]

bpc Trachybasalt of Pole Creek Road (Pliocene) - Apron of phenocryst-poor lava flows (46.9$48.9 \% \mathrm{SiO}_{2}$ ) that extends $\sim 13 \mathrm{~km}$ southward from south flank of Peavine Ridge; widely exposed along many tributaries of Bear, Trout, and Elk Creeks. No evidence found for vent location, which is probably buried by Jungle Butte Shield (unit bjb). Also crops out along gorges of White and Brush Creeks southeast of Oak Hill Shield and east of Klose Butte. 
Most rocks are massive, mottled, and block jointed or slabby; vesicular zones are only locally exposed; vesicle sheets and diktytaxitic texture are present but uncommon. Exposure is good on canyon rims where individual flows are 5-25 m thick; elsewhere, surfaces are mostly bouldery colluvium and corestones in loessic soil. Phenocrysts: typically aphyric, although a few flows contain sparse plag $(1-2 \mathrm{~mm})$ and rare olivine $(0.5-2 \mathrm{~mm})$; scattered fragments $(1-15 \mathrm{~mm})$ of plag megacrysts are sparse but widespread. North edge of unit banks against foot of Peavine Ridge Anticline at elevations of 2,500 to 2,700 ft; however, northwestern part of unit extends as high as 3,200 ft and may have been uplifted with

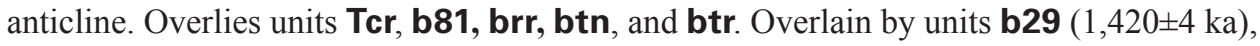
b68, b97, bbe, bbl (1,687 $\pm 5 \mathrm{ka})$, bdr, bec, bjb (1,350 $\pm 50 \mathrm{ka})$, bkl $(1,748 \pm 5 \mathrm{ka})$, bof ( $967 \pm 4 \mathrm{ka})$, boh $(981 \pm 14 \mathrm{ka})$, bsp $(3,278 \pm 8 \mathrm{ka})$, and bwe. Canyon-wall remnants of low-K diktytaxitic unit bsk appear to be intercalated between flows of unit bpc. ${ }^{40} \mathrm{Ar} /{ }^{39} \mathrm{Ar}$ age: $3,325 \pm 23 \mathrm{ka}$. [SP, OF, TB]

bpo Trachybasalt of Poland Butte (early Pleistocene)—Phenocryst-poor lava flows and ejecta (45.5-48.1\% $\mathrm{SiO}_{2}$ ) of small (3-km-wide) Poland Butte Shield Volcano, which is capped by a 70-m-high cone of scoria, spatter, and agglutinate. Lava-flow apron southeast of Tepee Creek divides southward into three discrete flow lobes. Most exposures are almost phenocryst-free, containing only rare olivine and rarer plag (each 1-3 mm). Unlike lava flows, near-vent ejecta have clusters of spinel-bearing olivine crystals, sparse plag megacrysts as big as $40 \mathrm{~mm}$, fragments of peridotite as big as $30 \mathrm{~mm}$, and angular fragments of intergrown cpx and olivine as big as $30 \mathrm{~mm}$. Cpx, plag, and clots of olivine disaggregated and dispersed from such cargo occur sparsely in some lava flows that are otherwise almost aphyric. Overlies units b73, bcr $(1,513 \pm 4 \mathrm{ka})$, bsi $(1,875 \pm 3 \mathrm{ka})$, btc, bw $(1,885 \pm 5 \mathrm{ka})$, and mtc. ${ }^{40} \mathrm{Ar} /{ }^{39} \mathrm{Ar}$ age: $1,101 \pm 3 \mathrm{ka}$. [PB, TB]

bpr Trachybasalt of Peavine Ridge Spring (early Pleistocene or Pliocene)—Isolated remnant of a single aphyric basaltic lava flow $\left(47.3 \% \mathrm{SiO}_{2}\right), 15-20 \mathrm{~m}$ thick, resting on unit Tcr on south slope of Peavine Ridge Anticline. No vent is exposed; flow may be an eroded outlier of compositionally similar unit bjs that spilled over Peavine Ridge. Crops out as massive blocks and slabs. Phenocrysts: none, but conspicuous olivine and plagioclase microphenocrysts $(0.2-0.4 \mathrm{~mm})$ are seriate to groundmass microlites. Overlain by unit bwk. Undated. [SP]

bps Trachybasalt of Pretty Swamp (middle Pleistocene)-Moderately porphyritic lava flows and ejecta $\left(49.2 \% \mathrm{SiO}_{2}\right)$ erupted at scoria cone just southeast of Pretty Swamp on Simcoe Mountains rangecrest. Cone consists largely of loose oxidized scoria lapilli and bombs, is $\sim 600 \mathrm{~m}$ wide, has $\sim 50 \mathrm{~m}$ relief, and is centered $700 \mathrm{~m}$ south of Kaiser Butte Guard Station, barely extending into south edge of map area $\sim 2 \mathrm{~km}$ east of Kaiser Butte. Because erupted through unit Tcr just south of anticlinal crest, lava flows advanced only southward. Phenocrysts: $5-8 \%$ plag $(1-8 \mathrm{~mm})$ and $\sim 1 \%$ oxidized 1-mm olivine. Overlies units Tcr and bkb (688 $\pm 25 \mathrm{ka})$. K-Ar age: $631 \pm 27 \mathrm{ka}$ (K. Uto, written commun., 2008; appendix B). [HB, WPB]

brr Basalt of River Route Road (Pliocene) - Diktytaxitic low-K tholeiitic basalt lava flows (48.5-48.7\% $\mathrm{SiO}_{2} ; 0.24-0.57 \% \mathrm{~K}_{2} \mathrm{O}$ ) exposed in two small outcrops-one in headwall scarp of Borde Flats slide mass, another nearby on both sides of Elk Creek at road bridge 1882. Multi-flow exposures are block jointed and as thick as $30 \mathrm{~m}$, draped by extensive plateau-capping flows of unit bpc. Both outcrops extend to crags as much as $30 \mathrm{~m}$ higher than near-planar surface of adjacent valley-filling unit bof. Exposures are more weathered than far younger unit bof, which is also diktytaxitic but distinguished by its abundance of starburst clusters (as big as $10 \mathrm{~mm}$ ) of olivine and plag microphenocrysts. Phenocrysts: none. Crystalline groundmass olivine and plag are seriate from microphenocrysts to microlites. Base not exposed. Both exposures are overlain by units bpc $(3,325 \pm 23 \mathrm{ka})$ and bof $(967 \pm 4 \mathrm{ka})$. Undated. [OF]

brs Trachybasalt of Satus Ranger Station Road (early Pleistocene) - Phenocryst-poor scoria, agglutinate, and fountain-fed lava flows $\left(48.6-48.7 \% \mathrm{SiO}_{2}\right)$ erupted at scoria Cone $3860+$ and adjacent fissure that built 1.8-km-long northeast-trending ridge, midway between Smith Butte and Camas Patch. Cone is $\sim 25 \mathrm{~m}$ high but fissure-fed ridge is generally only 10-15 m high. Scoria are coarsely to finely vesicular, and relatively few are oxidized. Phenocrysts: sparse plag (mostly $\leq 1 \mathrm{~mm}$ plus rare megacryst fragments as big as $5 \mathrm{~mm}$ ) and rare olivine 
(mostly $<0.5 \mathrm{~mm}$ ); groundmass conspicuously rich in plag microlites and microphenocrysts. Overlies units bfr, bsn (1,479 $\pm 3 \mathrm{ka})$, and bs $(1,722 \pm 5 \mathrm{ka})$. Undated. [CP] $\mathrm{SiO}_{2}$ ) of prominent shield volcano and its capping scoria cone, Smith Butte. High cone (elevation 4,856 ft) is culmination of highland drained radially by White Fir and Spring Creeks, South Fork Dry Creek, and North Fork Logy Creek. Scoria cone is 60-80 m high, capped by tack-welded agglutinate and loose scoria bombs and lapilli, and grades radially into lava flows. Lava-flow apron divides into three principal sectors: one tongue extends $5 \mathrm{~km}$ north-northwest and is now incised by White Fir Creek; middle lobe extends $8 \mathrm{~km}$ north-northeast as far as South Fork Dry Creek; and a third extends $12 \mathrm{~km}$ eastnortheast. Flows crop out as massive joint blocks and slabs, commonly finely granular and mottled. Phenocrysts: typically none. Locally contains traces of olivine and plag (mostly $\leq 0.3 \mathrm{~mm}$ but as big as $1 \mathrm{~mm})$, rare fragments $(1-8 \mathrm{~mm}$ ) of plag megacrysts, and very rare microgabbro inclusions as big as $20 \mathrm{~mm}$. Local 10 - to 100 -m-scale domains are lenses rich in entrained plag cumulates; close to contacts with plag-rich unit bfr, such domains might alternatively represent surficially entrained contaminants. Overlies units bcs $(1,882 \pm 48 \mathrm{ka})$, bfr, bgp, bhw, bld ( $3,841 \pm 14 \mathrm{ka})$, bln, bls, bnl, bsd, bsu, bta ( $3,464 \pm 4 \mathrm{ka})$, b14, and

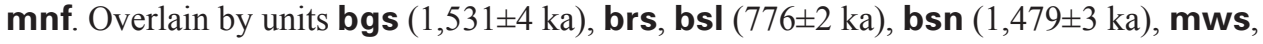
and mes. ${ }^{40} \mathrm{Ar} /{ }^{39} \mathrm{Ar}$ ages: Identical (analytically blind) ages of $1,722 \pm 5 \mathrm{ka}$ were given by samples taken at elevation 4,230 ft on northwest slope and at Road Junction 3290 on east apron, locations $9 \mathrm{~km}$ apart. [SB, HB, CP]

bsa Basalt of Satus Creek (early Pleistocene or Pliocene)—Diktytaxitic phenocryst-poor lava flows (48.8-49.8\% $\left.\mathrm{SiO}_{2} ; 15.9-16.6 \% \mathrm{Al}_{2} \mathrm{O}_{3} ; 0.32-0.74 \% \mathrm{~K}_{2} \mathrm{O}\right)$ that flowed down Wilson Charley Canyon, ponded as thickly as $70 \mathrm{~m}$ at its confluence with Satus Creek, and then flowed at least $9 \mathrm{~km}$ farther northeast down Satus Creek. As many as 10 flows, each 1-12 m thick, make up ledgy stacks on both sides of Highway 97 near confluence. Upper surface of unit is $85 \mathrm{~m}$ above its base near stream level at confluence; remnants downstream along Satus Creek descend gradually to stream level, consist of only 1-3 flows (each 1-8 m thick), and are locally covered by old terrace alluvium. Vent not identified but evidently northwest in Wilson Charley Canyon drainage, because remnants on both walls of Wilson Charley Canyon extend $3 \mathrm{~km}$ upstream and as high as $35 \mathrm{~m}$ higher than surface of unit at confluence. Lava stacks have thin rubbly scoriaceous partings between flows; most flows are hackly or block jointed and slightly vesicular as well as diktytaxitic throughout; only interior zones of thickest flows have massive nonporous texture; many flows contain vesicle cylinders and vesicle sheets. Some flows advanced exceptionally far for units of Simcoe Mountains volcanic field; no evidence was found for lava tubes, but exposures are mostly sidewall remnants, so tube transport cannot be excluded. Phenocrysts: sparse olivine and plag (both generally $\leq 1 \mathrm{~mm}$ ) plus rare plag megacrysts as big as $10 \mathrm{~mm}$. Groundmass is commonly rich in plag and olivine microlites seriate to microphenocrysts. Rests on unit Tcr and is overlain by units bww and bww'. Undated. [LCSW, KC]

bsb Trachybasalt of Sheep Butte (early Pleistocene)—Phenocryst-rich lava flows and ejecta (48.3-49.4\% $\mathrm{SiO}_{2}$ ) erupted at scoria Cone 4422, called Sheep Butte, in headwaters of Sheep Creek. Cone is $110 \mathrm{~m}$ high, $750 \mathrm{~m}$ wide, and its scoria bombs and lapilli are oxidized but not agglutinated. Lava-flow apron descends and widens westward, 2-3 km to upper Sheep Creek, and crops out as massive ledges and joint blocks. Phenocrysts: in lava flows, $8-12 \%$ plag $(1-5 \mathrm{~mm}$ ) plus megacryst fragments $(1-18 \mathrm{~mm}) ; 1-2 \%$ olivine (mostly $1-2 \mathrm{~mm}$, commonly in clusters; a few crystals as big as $8 \mathrm{~mm}$ ); and $1-2 \%$ cpx (mostly $1-2 \mathrm{~mm}$ but also as big as $8 \mathrm{~mm}$ ). Scoria bombs of vent cone carry same phenocryst assemblage but roughly half as abundant. Overlies units bst and bus and appears to bank against unit bns $(1,566 \pm 3 \mathrm{ka})$. Overlain by units mes and bgs $(1,531 \pm 4 \mathrm{ka})$. Undated. [HB]

bsc Trachybasalt of Summit Creek (early Pleistocene)-Aphyric lava flows (47.7-49.3\% $\mathrm{SiO}_{2}$ ) that erupted from a vent now concealed by younger units, probably beneath Hagerty Butte Shield. Lava flows emerge from under unit bhb just southwest of Hagerty Butte, crop out continuously southwestward along canyon of Summit Creek, and are trucated by landslide scarp north of Grayback Mountain. Slabby to block-jointed lavas are mostly massive but locally weakly diktytaxitic. Despite continuity and lithologic uniformity, unit has unusually wide chemical range $-4.2-6.7 \% \mathrm{MgO}$ and $0.99-2.18 \% \mathrm{~K}_{2} \mathrm{O}(\mathrm{n}=6)$. Phenocrysts: generally 
aphyric but locally contains trace amounts of olivine and plag $(<0.5-1 \mathrm{~mm})$ and rare fragments of plag megacrysts as big as $25 \mathrm{~mm}$. Groundmass olivine (mostly $<0.3 \mathrm{~mm}$ ) is locally well developed. Three domains (marked $\mathbf{X}$ on map) of plag-rich cumulate, each $30-50 \mathrm{~m}$ long, that were apparently swept along in a nearly aphyric lava flow, crop out on west wall of Summit Creek gorge 1.5-2 km upstream from its confluence with Featherbed Creek. Rests on unit Tcr and banks against unit b82. Overlain by all other contiguous unitsbcv, bfc $(681 \pm 2 \mathrm{ka})$, bhb $(1,276 \pm 4 \mathrm{ka})$, and bss. ${ }^{40} \mathrm{Ar} /{ }^{39} \mathrm{Ar}$ age: $1,675 \pm 5 \mathrm{ka}$. [TB, HB]

bsd Trachybasalt and basalt of South Fork Dry Creek (early Pleistocene)-Moderately phenocryst-rich lava flows (47.9-49.1\% $\mathrm{SiO}_{2}$ ) that emerge from beneath younger units on northeast slope of Smith Butte Shield and extend $5.5 \mathrm{~km}$ northward to South Fork Dry Creek. Unit is generally only $5-15 \mathrm{~m}$ thick and widely stripped from underlying units, resulting in ragged discontinuous map pattern. Crops out as massive blocks and slabs, only locally vesicular. Phenocrysts: $5-15 \%$ plag (most $1-5 \mathrm{~mm}$, plus unevenly distributed fragments of plag megacrysts, $1-15 \mathrm{~mm}$ ); sparse 1-mm olivine; and rare 1-mm cpx (recognized only in northerly exposures). Locally, 10- to 100-m-scale domains are enriched in $10-15 \mathrm{~mm}$ plag, probably entrained slugs of cumulates. Chemically, unit is fairly heterogeneous, with ranges of $1.10-1.84 \% \mathrm{~K}_{2} \mathrm{O}$ and $2.03-3.51 \% \mathrm{TiO}_{2}(\mathrm{n}=9)$. Overlies units Tcr, bcf, bdf, bds, bfr, bta ( $3,464 \pm 4 \mathrm{ka})$, bsu, mns, and $\mathbf{m s g}$. Overlain by units bs $(1,722 \pm 5 \mathrm{ka})$ and bcs $(1,882 \pm 48 \mathrm{ka})$. Undated. [SB, CP]

bsf Trachybasalt of Starvation Flats (early Pleistocene) - Phenocryst-poor lava flows (47.8$49.0 \% \mathrm{SiO}_{2}$ ) that crop out as low-relief plateau extending from North Fork Dry Creek canyon for $5 \mathrm{~km}$ northeastward into alcove of Starvation Flats at foot of Toppenish Ridge Anticline. Unit is as thick as $10-15 \mathrm{~m}$ on canyon rim but its gently undulating surface is little incised; broad depressions on surface are filled with unstratified silt and sand, pale gray or tan, exposed to depths of 1-4 m along arroyos, and either barren or supporting sparse bunchgrass and sagebrush. Flows crop out as joint blocks, mostly weakly vesicular and deeply weathered, that armor rocky meadows or form rimrock ledges. Phenocrysts: $1-5 \%$ plag (most $1-5 \mathrm{~mm}$, plus scattered fragments as big as $18 \mathrm{~mm}$ of plag megacrysts); sparse olivine and sparser cpx (both $\leq 1 \mathrm{~mm}$ ). Overlies units Tcr and bwl. Overlain by unit bnf $(1,533 \pm 3 \mathrm{ka}) .{ }^{40} \mathrm{Ar} /{ }^{39} \mathrm{Ar}$ age: $2,060 \pm 10 \mathrm{ka} .[\mathrm{CP}]$

bsh Trachybasalt and basalt of Schafer Creek (Pliocene)-Phenocryst-poor lava flows (46.8$49.3 \% \mathrm{SiO}_{2}$ ) that cap plateau south of Twin Buttes between Schafer and Summit Creeks; also forms walls of 4-km-long reach of Brush Creek gorge upstream from Blue Creek. Lava flowed at least $13 \mathrm{~km}$ southwestward from a vent possibly (not certainly) marked by scoria Cone 2965 (unit b65). Unit is $75 \mathrm{~m}$ thick at its eroded terminus on east rim of Klickitat River canyon and as thick as $90 \mathrm{~m}$ along Brush Creek gorge. Exposures are mostly block-jointed rim ledges or slabs and boulders eroding out of thick loessic soil. Most rocks are nearly aphyric, although their massive, mottled, granular groundmass is commonly studded with tiny olivine grains $(0.1-0.3 \mathrm{~mm})$. Some flows locally contain sparse olivine phenocrysts $(0.5-2 \mathrm{~mm})$, a trace of plagioclase laths $(1-2 \mathrm{~mm})$, and rare megacrystic plagioclase fragments as big as $10 \mathrm{~mm}$. Overlies units Tcr, $\mathbf{b c l}(3,298 \pm 10 \mathrm{ka}), \mathbf{b s p}(3,280 \pm 8$ ka), and b82. Overlain by units b66, bbl $(1,687 \pm 5 \mathrm{ka}), \mathbf{b c v}$, bes, bmb $(2,079 \pm 5 \mathrm{ka})$, bnb $(1,328 \pm 2 \mathrm{ka})$, and btb $(3,262 \pm 5 \mathrm{ka}) \cdot{ }^{40} \mathrm{Ar} /{ }^{39} \mathrm{Ar}$ age: $3,251 \pm 7 \mathrm{ka}$. [TB, OF]

bsi Trachybasalt and basalt of Simon Butte (early Pleistocene)—Phenocryst-poor lava flows and ejecta (46.9-48.8\% $\mathrm{SiO}_{2}$ ) that erupted at site of 190-m-high scoria cone, Simon Butte, between headwaters of Brush and Tepee Creeks. From base of 1.5-km-wide cone, apron of lava flows extends $3 \mathrm{~km}$ northwest and $9 \mathrm{~km}$ southwest. Low-relief apron rarely has more than $20 \mathrm{~m}$ exposure, even at stream-cut margins. Crops out as massive or slightly vesicular ledges, locally platy, but predominantly as weathered joint blocks in loessic soil. Phenocrysts: sparse plag, ranging from trace amounts to $2-3 \%$ (mostly $1-2 \mathrm{~mm}$, rarely to $5 \mathrm{~mm}$ ), plus scattered fragments $(1-30 \mathrm{~mm})$ of plag megacrysts; mafic phenocrysts rare to absent, although olivine microphenocrysts $(<0.5 \mathrm{~mm})$ are locally discernible in groundmass. Exceptional is subordinate population of scoria and agglutinate blocks (observed only high on cone through mantle of aphyric unit asi) that are rich in antecrystic cargo-olivine (1-3 mm), cpx (1-3 mm), and plag (2-15 mm). Overlies units a72 (3,273 $\pm 12 \mathrm{ka})$, bmc, bsw, btc, b22, and b31. Overlain by units b37, b85, asi, mtc, bcr (1,513 $\pm 4 \mathrm{ka})$, bmf, bnf $(1,533 \pm 3 \mathrm{ka})$, and bpo $(1,101 \pm 3 \mathrm{ka}) \cdot{ }^{40} \mathrm{Ar} /{ }^{39} \mathrm{Ar}$ age: $1,875 \pm 3 \mathrm{ka}$. [MB, PB] 
bsk Basalt southeast of Klose Butte (Pliocene)—Diktytaxitic low-K tholeiitic basalt lava flows (48.4-48.6\% $\left.\mathrm{SiO}_{2} ; 0.37-0.38 \% \mathrm{~K}_{2} \mathrm{O}\right)$ exposed on west wall of White Creek gorge and southeast wall of lower Brush Creek gorge near their confluence. At White Creek, discontinuously exposed ledges, each 2-5 $\mathrm{m}$ high, representing at least two flows, are block jointed, locally columnar, and extend for $\sim 700 \mathrm{~m}$ along gorge wall $\sim 80 \mathrm{~m}$ below rim, at elevations of 640-670 m (2,100 to 2,200 ft). About $800 \mathrm{~m}$ east of those ledges and $700 \mathrm{~m}$ upstream from confluence of Brush and White Creeks, an 8-m-high ledge of identical basalt crops out at $\sim 655 \mathrm{~m}(\sim 2,150 \mathrm{ft})$ elevation on steep southeast wall of Brush Creek. Phenocrysts: none. Crystalline groundmass olivine and plag are seriate from microphenocrysts to microlites. On scree-covered canyon walls, poorly exposed ledges appear to be intercalated within stacks of flows of unit bpc $(3,325 \pm 23 \mathrm{ka})$. That they might be banked against such stacks has not been ruled out but appears unlikely. Undated. [TB]

bsl

bsm, bsm'

bsn
Trachybasalt of South Fork Logy Creek (middle or early Pleistocene)_Phenocryst-poor lava flows (48.4-50.3\% $\mathrm{SiO}_{2}$ ) that issue from beneath unit byt on north slope of Simcoe Shield, $\sim 3 \mathrm{~km}$ north of Tadpole Lake, and descend along north side of South Fork Logy Creek for 5 $\mathrm{km}$ before spreading out as plateau-capping sheet that extends $\sim 8 \mathrm{~km}$ farther, almost as far as Logy Creek Falls. Vent concealed by unit byt, probably near Tadpole Lake. Unit is as thick as $60 \mathrm{~m}$ medially, thinning eastward to 3-12 m rimrock ledges on distal plateaus. Lava flows are generally massive and slabby or block jointed, and only locally vesicular. Phenocrysts: sparse to common olivine (mostly microphenocrysts $\leq 0.5 \mathrm{~mm}$ ) and sparser plag $(\leq 1 \mathrm{~mm})$; very rare cpx. Irregularly distributed plag megacrysts $(\geq 10 \mathrm{~mm})$, typically shattered, locally obscure crystal-poor nature of unit; but, generally all three mineral phases are smaller than $0.5 \mathrm{~mm}$, rendering its appearance nearly aphyric. Overlies units Tcr, b14, b41, blc, bln, bs $(1,722 \pm 5 \mathrm{ka})$, bys, mcc, mnf, and $\mathbf{m s l}(3,550 \pm 4 \mathrm{ka})$. Overlain by unit byt ( $674 \pm 4 \mathrm{ka})$. ${ }^{40} \mathrm{Ar} /{ }^{39} \mathrm{Ar}$ age: $776 \pm 2 \mathrm{ka}$. [SB, LCSW, LCF]

Trachybasalt of Stagman Butte (early Pleistocene)-Aphyric lava flows and ejecta (47.4$48.6 \% \mathrm{SiO}_{2}$ ) that erupted at broad meadow-capped shield of Stagman Butte (elevation $5,166 \mathrm{ft}$ ). Because shield is banked against west side of slightly higher Logy Creek divide (unit bld), flows of Stagman Butte advanced only westward, forming an apron that crops out for $4 \mathrm{~km}$ to headwaters of Twentyfive Mile Creek where it disappears beneath younger units. Lava flows crop out as massive joint blocks and slabs, locally vesicular. Phenocrysts: generally none, although rare olivine $(0.5-1 \mathrm{~mm})$ is locally seriate to tiny groundmass olivine. Sparse fragments of plag megacrysts as large as $10 \mathrm{~mm}$ are widely scattered, but normal plag phenocrysts are rare or absent. Massive block-jointed flows armor well-exposed grasslands atop shield; although sparse cinders are strewn about on its windblown surface, scoria and agglutinate crop out well only on steep north slope of summit plateau. Distinctive feldspar-rich lava flows (48.1-49.1\% $\left.\mathrm{SiO}_{2}\right)$, exposed only in two windows on south and west slopes of Stagman Butte, are interlayered in main stack of aphyric lavas and are designated subunit bsm'. In common with predominant aphyric flows, this variant virtually lacks olivine and cpx, but it carries a varied cargo (5-12\%) of plag (3-10 mm), all or most of it fragments of shattered megacrysts. Subunit may represent domains of entrained plagioclase cumulates rather than independent flow units; compared to aphyric host, however, three samples analyzed are not significantly elevated in $\mathrm{Al}_{2} \mathrm{O}_{3}$ (16.4-17.1\%). Base of subunit not exposed; both exposures are surrounded by main aphyric unit bsm, which overlies units bld $(3,841 \pm 14 \mathrm{ka})$, bob, and but. Overlain by units bnk, bnt, bnw, and bws. ${ }^{40} \mathrm{Ar} /{ }^{39} \mathrm{Ar}$ age: $2,056 \pm 25 \mathrm{ka}$. [SB, HB]

Trachybasalt north of Smith Butte (early Pleistocene) - Sparsely to moderately porphyritic lava flows and ejecta $\left(50.3-51.3 \% \mathrm{SiO}_{2}\right)$ erupted from scoria Cone 4702 , centered $1 \mathrm{~km}$ north-northeast of summit of Smith Butte. Cone is $\sim 1 \mathrm{~km}$ wide, $70 \mathrm{~m}$ high, and grades into a multilobate lava-flow apron (2-2.5 km wide) that extends $6 \mathrm{~km}$ northward to Camas Patch lowlands. Lava flows crop out as joint blocks and slabs, widely massive but commonly vesicular. Phenocrysts: unusual range (1-7\%) in plag content (mostly $1-3 \mathrm{~mm}$, plus scattered fragments as big as $10 \mathrm{~mm}$ of plag megacrysts; sparse olivine $(0.5-1 \mathrm{~mm})$; and rare or no cpx $(\sim 1 \mathrm{~mm})$. Plag content tends generally to increase distally, though not consistently, and cpx distribution appears to be unsystematic. Rare angular inclusions of microgabbro as big as 30 mm occur locally. Overlies units bc2, bc6, bcs (1,882 $\pm 48 \mathrm{ka}), \mathbf{b f r}$, bgs (1,531 $\pm 4 \mathrm{ka})$, and bs $(1,722 \pm 5 \mathrm{ka})$. Overlain by unit brs. ${ }^{40} \mathrm{Ar} /{ }^{39} \mathrm{Ar}$ age: $1,479 \pm 3 \mathrm{ka} .[\mathrm{SB}, \mathrm{CP}]$ 

flows $\left(49.9 \% \mathrm{SiO}_{2}\right)$ that support a shelf and slope adjacent to younger Cone 2784 (unit b27), with which this unit jointly forms a 1-km-wide window surrounded by younger flows of Oak Hill Shield (unit boh). Exposures are largely colluvial rubble or corestones in thick loessic soil, but they include a few block-jointed outcrops. Phenocrysts: abundant plag (1-8 mm); sparse olivine and cpx (both $\leq 1 \mathrm{~mm}$ ). Base not exposed. Overlain by units b27 and boh (981 $14 \mathrm{ka})$. Chemically distinct from petrographically similar unit b29 (2-3 km north and west). Undated. [OF]

bsp Trachybasalt east of Schafer Pocket (Pliocene)—Phenocryst-poor lava flows (48.6-50.1\% $\mathrm{SiO}_{2}$ ) that crop out for $\sim 2 \mathrm{~km}$ along southeast rim of White Creek gorge above confluence of Schafer Creek. Unit is $\sim 30 \mathrm{~m}$ thick, generally block jointed or platy, and commonly mottled. Source vent unknown, but flows are compositionally similar to much younger unit bbl. Phenocrysts: typically aphyric but carries rare plag fragments and tiny groundmass olivine. Overlies units Tcr and bpc $(3,325 \pm 23 \mathrm{ka})$. Overlain by units bsh $(3,251 \pm 7 \mathrm{ka})$, btb $(3,262 \pm 5 \mathrm{ka})$, and bcr $(1,513 \pm 4 \mathrm{ka}) \cdot{ }^{40} \mathrm{Ar} /{ }^{39} \mathrm{Ar}$ age: $3,280 \pm 8 \mathrm{ka}$. [TB]

Trachybasalt of Shamrock Spring (early Pleistocene)-Moderately porphyritic lava flows and ejecta (46.9-49.1\% $\mathrm{SiO}_{2}$ ) erupted at site of small 40-m-high scoria cone, $1 \mathrm{~km}$ south of Shamrock Spring. Major lava-flow apron extends east and south to White Creek, forming south-sloping plateau that reaches as far as $6 \mathrm{~km}$ southward, dividing into two lobes around Cone 2862 (unit b62). Cone is strewn with oxidized cinders and scoriaceous blocks. Flows are generally massive, locally vesicular, and crop out as knobs and ledges or as joint blocks in loessic soil. Phenocrysts: $5-10 \%$ plag, unusually varied in amount and morphology; mostly $1-5 \mathrm{~mm}$ but fragments of shattered plag megacrysts are $5-15 \mathrm{~mm}$; sparse to common olivine $(0.5-2 \mathrm{~mm})$. Cpx observed only in rare angular inclusions as tiny crystals $(<0.5 \mathrm{~mm})$ intergrown with plag and olivine. Overlies units Tcr, b62, b84, b94, b97, bix, blo, bw $(1,885 \pm 5 \mathrm{ka})$, and bwk. Overlain by units bly $(1,697 \pm 20 \mathrm{ka})$ and boh $(981 \pm 14 \mathrm{ka})$. ${ }^{40} \mathrm{Ar} /{ }^{39} \mathrm{Ar}$ age: $1,685 \pm 11 \mathrm{ka}[\mathrm{PB}]$

bss Basalt south of Summit Creek (early Pleistocene)-Moderately porphyritic lava flows and ejecta (47.6-49.5\% $\mathrm{SiO}_{2}$ ) erupted at 75-m-high scoria Cone 3404, $3 \mathrm{~km}$ north of Kaiser Butte Guard Station. Single tongue of lava 1-1.5 km wide flowed $8 \mathrm{~km}$ westward between Summit and Featherbed Creeks to their confluence and $\sim 800 \mathrm{~m}$ farther, past confluence of Cedar Creek. Crops out as massive block-jointed rim ledges or as weathered blocks in thick soil. Phenocrysts: 5-8\% plag (1-3 mm) plus plag megacryst fragments to $10 \mathrm{~mm}$; sparse olivine $(0.5-1 \mathrm{~mm})$; still sparser cpx $(1-2 \mathrm{~mm})$ may become slightly more common with distance from vent. Overlies units Tcr and bsc (1,675 $\pm 5 \mathrm{ka})$. Overlain by units bhb $(1,276 \pm 4 \mathrm{ka})$ and $\mathbf{b f c}(681 \pm 2 \mathrm{ka})$. Undated. [HB, TB]

bst Trachybasalt of Stag trig (early Pleistocene) - Nearly aphyric lava flows and ejecta (48.1$48.9 \% \mathrm{SiO}_{2}$ ) erupted at scoria Cone 4889 (near top of which lies Stag trig), centered $2.5 \mathrm{~km}$ northwest of Stagman Butte. Cone is 70-90 m high, $700 \mathrm{~m}$ wide, and consists largely of loose or tack-welded oxidized scoria. A broad lava-flow apron descends $2 \mathrm{~km}$ northward to upper Sheep Creek and $3 \mathrm{~km}$ westward to headwaters of Blue Creek. Lava flows crop out as massive ledges, slabs, or joint blocks and are either phenocryst free or contain only trace amounts of olivine, plag, and cpx, all smaller than $1 \mathrm{~mm}$. Rare fragments of olivine and plag megacrysts as big as $5 \mathrm{~mm}$ were observed locally. Overlies units bnt, bus, and bwp. Overlain by units mes, mws, bnw, and bsb. Undated. [HB]

bsu Basalt of upper Spring Creek (early Pleistocene) - Phenocryst-poor subalkaline lava flows (46.2-48.8\% $\mathrm{SiO}_{2}$ ) that emerge from beneath younger units $\sim 4 \mathrm{~km}$ northeast of Smith Butte and extend $2.5 \mathrm{~km}$ northeastward along both sides of upper Spring Creek. Lava flows crop out as massive joint blocks and ledges; maximum relief exposed $\sim 30 \mathrm{~m}$ on east slope of Spring Creek. Phenocrysts: $1-3 \%$ each of plag $(1-3 \mathrm{~mm})$ and olivine $(0.5-1 \mathrm{~mm})$; olivine tends to exceed plag proximally, but plag dominates distally. Overlies unit bta $(3,464 \pm 4 \mathrm{ka})$. Overlain by units bc5, bc5', bgp, bs $(1,722 \pm 5 \mathrm{ka})$, and bsd. Undated. [SB, CP]

bsw Basalt west of Simon Butte (early Pleistocene)-Olivine-rich lava flow (46.9\% $\left.\mathrm{SiO}_{2}\right)$ that crops out only on west bank of an upper tributary of Brush Creek, at west toe of Simon Butte. Exposed between extensive adjoining units, window is only $250 \times 350 \mathrm{~m}$ in area and has $<15 \mathrm{~m}$ relief. Source vent buried by younger units, its location unknown. Phenocrysts: $5-8 \%$ olivine $(1-5 \mathrm{~mm})$, some in clusters; unusually wide range of plag content $(0-5 \%)$, 
including scattered fragments of plag megacrysts as big as $15 \mathrm{~mm}$; very rare cpx ( 1 mm). Base not exposed. Overlain by units bsi $(1,875 \pm 3 \mathrm{ka})$ and bcr $(1,513 \pm 4 \mathrm{ka})$. Undated. [MB]

Trachybasalt of Schwartz Line (Pliocene) - Phenocryst-poor lava flows (47.6-49.3\% $\mathrm{SiO}_{2}$ ) exposed in a belt that extends from headwaters of South Fork Toppenish Creek (at north edge of map area) across Toppenish-White Creek divide (where it crops out widely near Signal Peak Road) and $5 \mathrm{~km}$ farther southward down uppermost White Creek. Chemically and lithologically similar unit btp crops out along rim of Toppenish Creek $2-8 \mathrm{~km}$ east of unit bsz. Vent presumed to be northwest of map area, probably concealed beneath unit blp on Lincoln Plateau. Deeply eroded lava flows are exposed as ledges, slabs, and joint blocks, nearly all massive. Phenocrysts: $<1 \%$ plag ( $1-4 \mathrm{~mm}$, some rounded) plus sparse plag megacryst fragments $(5-20 \mathrm{~mm})$; typically free of mafic phenocrysts except for rare $0.5-2-\mathrm{mm}$ olivine locally. Overlies units Tcr, buw, and msk (3,685 $\pm 143 \mathrm{ka})$. Overlain by units msp (3,286 $\pm 6 \mathrm{ka})$, bew, bix, blo, blp (3,278 $\pm 4 \mathrm{ka})$, bwh, bwr, b01, and b84. ${ }^{40} \mathrm{Ar} /{ }^{39} \mathrm{Ar}$ age: $3,323 \pm 6 \mathrm{ka}$. [PB, LHP]

bta

btb

btc

bte
Trachybasalt of Tannawasha Pasture (Pliocene) - Phenocryst-poor lava flows (47.2-50.3\% $\mathrm{SiO}_{2}$ ) that emerge from beneath younger units near upper Spring Creek and extend $15 \mathrm{~km}$ eastward as far as Logy Creek rim, $1.5 \mathrm{~km}$ east of Logy Creek Falls. Massive block-jointed flows, locally hackly or slabby, form rimrock ledges and rocky meadows on extensive plateau between Spring and Dry Creeks medially and plateau of Tannawasha Pasture between Spring and Logy Creeks distally. Most flows are 8-15 $\mathrm{m}$ thick but as thin as 3-6 m distally; total thickness of unit 30-50 m medially. Phenocrysts: locally aphyric; some flows carry sparse plag $(1-3 \mathrm{~mm})$, rare olivine $(1-2 \mathrm{~mm})$, and rare fragments of plag megacrysts as big as $6 \mathrm{~mm}$. One or more flows east of Bergie Springs are slightly more calcic and carry as much as $1 \%$ plag and trace amounts of cpx (1-2 mm), commonly in clots with plag. Overlies units Tcr, b14, b41, bbw, btw (3,325 $45 \mathrm{ka})$, and bys ( $3,667 \pm 27 \mathrm{ka})$. Overlain by units mns, bgp, bsd, bsu, and bs $(1,722 \pm 5 \mathrm{ka}) \cdot{ }^{40} \mathrm{Ar} /{ }^{39} \mathrm{Ar}$ age: $3,464 \pm 4 \mathrm{ka}$. [CP, LCF]

Trachybasalt and basalt of Twin Buttes (Pliocene) - Sparsely to moderately porphyritic lava flows and ejecta (46.7-49.0\% $\mathrm{SiO}_{2}$ ) of Twin Buttes Shield Volcano, which is capped by a pair of 85-m-high scoria cones, near east rim of White Creek gorge. Remnants of similar flows on west rim and near gorge floor suggest that gorge had been cut to nearly its present depth prior to Twin Buttes eruptions and that Twin Buttes lavas locally filled gorge before erosion removed most of them. Flows are massive or slightly vesicular, forming blockjointed or slabby rim ledges or weathered blocks in thick soil. Phenocrysts: $1-5 \%$ olivine (1-3 mm), commonly in clusters. Plag $(1-5 \mathrm{~mm})$ ranges from absent or rare to about $1 \%$. Cpx is sparse, usually 1-2 mm, can equal or exceed feldspar in abundance, and rarely occurs as broken megacrysts $(5-8 \mathrm{~mm})$. Ejecta of southwest cone range from loose scoria to massive or slabby agglutinate and carry abundant olivine and sparse small plag. Ejecta of northeast cone likewise range from cinders to dense agglutinate but contain megacrysts of plag and cpx (both as big as $10 \mathrm{~mm}$ ) as well as abundant clustered 1-mm olivine. Overlies units Tcr, bpc $(3,325 \pm 23 \mathrm{ka})$, bsh ( $3,251 \pm 7 \mathrm{ka})$, bsp (3,278 $\pm 8 \mathrm{ka})$, and bwe. Overlain by units bkl $(1,748 \pm 5 \mathrm{ka})$, bbl $(1,687 \pm 5 \mathrm{ka})$, bof $(967 \pm 4 \mathrm{ka})$ and bcr $(1,513 \pm 4 \mathrm{ka})$, which is banked in at White Creek canyon rim. ${ }^{40} \mathrm{Ar} /{ }^{39} \mathrm{Ar}$ age: $3,262 \pm 5 \mathrm{ka}$. [TB]

Basalt of Tepee Creek (early Pleistocene) - Moderately porphyritic lava flows (48.3-48.5\% $\mathrm{SiO}_{2}$ ) exposed in narrow swath along shallow east fork of Tepee Creek for $4 \mathrm{~km}$, continuing $2 \mathrm{~km}$ farther downstream below confluence with main fork. Massive flows crop out as ledges and rounded joint blocks. Phenocrysts: $7-10 \%$ plag (mostly $1-4 \mathrm{~mm}$ but as big as $10 \mathrm{~mm}$ plus megacryst fragments to $20 \mathrm{~mm}) ; 2-3 \%$ olivine $(1-3 \mathrm{~mm})$; cpx $(1-2 \mathrm{~mm})$ rare to sparse. Base not exposed. Overlain by units $\mathbf{m t c}$, b94, bpo (1,101 $\pm 3 \mathrm{ka})$, bsi $(1,875 \pm 3 \mathrm{ka})$, and probably by b31. Undated. [PB, MB]

Trachybasalt of Tenie Creek (Pliocene)—Phenocryst-poor lava flows (48.6-49.7\% $\mathrm{SiO}_{2}$ ) that cap grassland plateaus south of Yatama Creek and extend at least $9 \mathrm{~km}$ from toe of Simcoe Shield (unit $\mathbf{m s r}$ ) as far as distal Tenie Creek. Outcrop area is $3 \mathrm{~km}$ wide between Yatama and Kusshi Creeks but narrows distally to dissected remnants. Total thickness (of two flows) along Kusshi Creek is $\sim 25 \mathrm{~m}$, thinning northeastward to as little as $3-5 \mathrm{~m}$ for rimrock of a single flow capping plateau east of Logy Creek Falls. Flows crop out slabby, platy, hackly, or block jointed, only rarely vesicular. Scattered about plateaus, partly deflated mounds of grass-bound loess, typically 1-2 $\mathrm{m}$ high and 10-100 m wide, provide evidence for formerly 
widespread cover of thick loessic soil; deflation of loess blanket has left plateaus strewn with lag of rounded joint blocks and slabs - formerly corestones. Source vent not identified, but unit may be a less evolved predecessor of comparably crystal-poor shield-forming unit msr. Phenocrysts: few to none; typically aphyric. Locally contains rare plag $(\leq 1 \mathrm{~mm})$ and olivine $(0.5-1 \mathrm{~mm})$. Also has very rare fragments of plag megacrysts as big as $4 \mathrm{~mm}$ and subangular inclusions $(1-15 \mathrm{~mm})$ of intergrown plag and cpx crystals $(0.5-1 \mathrm{~mm})$. Massive fine-grained groundmass commonly shimmers with plag microlites. Overlies units Tcr, bys $(3,667 \pm 27 \mathrm{ka}), \mathbf{m k c}$, and rtc. Overlain by unit $\mathbf{m s r}(3,465 \pm 4 \mathrm{ka})$; also older than unit byt (674 $\pm 4 \mathrm{ka}$ ), which banks against it. ${ }^{40} \mathrm{Ar} /{ }^{39} \mathrm{Ar}$ age: $3,447 \pm 10 \mathrm{ka}$. [LCSW, LCF, LCNE]

bth Basalt of Toppenish Ridge (early Pleistocene) - Moderately phenocryst-rich lava flows and ejecta (48.6-48.8\% $\mathrm{SiO}_{2}$ ) erupted at small spatter cone on crest of Toppenish Ridge Anticline, just east of Oak Spring. Lava-flow apron, $\sim 1 \mathrm{~km}$ wide, descends south limb of anticline. Another lava-flow remnant, $1.5 \mathrm{~km}$ long, hugs north flank of anticline. Between them, a 600-m-wide gap demonstrates considerable erosion along steep north limb. Lava flows crop out as massive ledges and joint blocks or, near vent, as vesicular blocks and knobby agglutinate. Phenocrysts: abundant small olivine $(0.3-1 \mathrm{~mm})$, sparse $1-\mathrm{mm} \mathrm{cpx}$, and common plag phenocrysts ( $1-3 \mathrm{~mm}$ ), plus scattered fragments of plag megacrysts (as big as $20 \mathrm{~mm})$. Overlies units Ter and boc $(2,136 \pm 5 \mathrm{ka})$. Overlain by units bor, bts, and bnf $(1,533 \pm 3 \mathrm{ka})$. Undated. [MB]

btn Basalt north of Trout Creek (Pliocene) - Distinctive lava flow (49.6-49.8\% $\mathrm{SiO}_{2}$ ) rich in tiny olivine that crops out in two limited areas (together $\sim 1 \mathrm{~km}^{2}$ ) at southern foot of Peavine Ridge Anticline, just west of confluence of Pole and Trout Creeks. Greatest thickness $\sim 15-25 \mathrm{~m}$, but exposure is limited by overlying unit bpc (which divides btn in two). Location of source vent unknown. Rocks are massive or slightly vesicular blocks and slabs. Phenocrysts: none. Groundmass olivine $(0.1-0.4 \mathrm{~mm})$ is abundant and characteristic of unit. Rests on unit Tcr. Overlain by unit bpc $(3,325 \pm 23 \mathrm{ka})$. Undated. [SP]

btp Trachybasalt of Toppenish Creek (Pliocene) - Aphyric lava flows (47.1-47.7\% $\mathrm{SiO}_{2}$ ) exposed as cliff-forming unit on both walls of lower South Fork Toppenish Creek and extending $5 \mathrm{~km}$ east along south wall of main fork to its confluence with White Deer and Surprise Creeks. Thickness 20-70 m for several kilometers along South Fork; at eastern limit of preservation, however, unit thickens to $\sim 100 \mathrm{~m}$ where it draped $>150 \mathrm{~m}$ of paleorelief on unit Tcr. Because unit slopes gently eastward, vent is presumed to be covered by younger units to west or northwest; chemical and lithologic similarity to unit bsz (3,323 $\pm 6 \mathrm{ka})$ suggests source on Lincoln Plateau north of map area. Roadcuts crossing South Fork expose stacks of five or more lava flows, all lithologically and chemically similar; such stacks are elsewhere inferred but seldom distinguishable on colluvium-mantled slopes. Massive interior zones are block jointed or slabby, 3-8 $\mathrm{m}$ thick, and grade through thin vesicular tops and bottoms to scoriaceous interflow rubble zones 1-3 m thick. Vesicle sheets and cylinders occur locally. Phenocrysts: generally none, although sparse fragments of shattered plag megacrysts (1-10 $\mathrm{mm}$ ) are widespread, and rare olivine and cpx megacrysts (to $5 \mathrm{~mm}$ ) were observed locally. Where exposed in South Fork roadcut, base rests on $5 \mathrm{~m}$ of red-orange oxidized colluvium developed atop unit Tcr. Overlies units Tcr and bdl. Overlain by units bwh and boc $(2,136 \pm 5 \mathrm{ka})$. Undated. [PB, MB]

btr Basalt of Trout Creek (Pliocene) - Moderately porphyritic low-K basaltic lava flows (50.2$50.7 \% \mathrm{SiO}_{2} ; 0.32-0.36 \% \mathrm{~K}_{2} \mathrm{O}$ ) that crop out for $\sim 2 \mathrm{~km}$ along east wall of Trout Creek gorge southeast of Jungle Butte. Flows are massive, commonly vesicular, block jointed, and form spottily exposed ledgy outcrops $5-10 \mathrm{~m}$ high along canyon wall. Phenocrysts: abundant olivine (1-2 mm), some skeletal or prismatic, commonly clustered; sparse to common plag (1-4 mm). Also has plag-olivine clots and conspicuous plag microlites. Base not exposed. Underlies unit bpc $(3,325 \pm 23 \mathrm{ka})$. Undated. [SP, OF]

bts Trachybasalt south of Toppenish Ridge (early Pleistocene)—Phenocryst-poor ejecta and fountain-fed lava flows $\left(48.8 \% \mathrm{SiO}_{2}\right)$ of small spatter cone and derivative apron of thin flows that make up 90-m-high buttress on south slope of Toppenish Ridge Anticline. Summit consists of variably agglutinated spatter, ranging from coarse blocks of blobby oxidized agglutinate to loose red scoria; lava flows on slope range from streaky to massive, hackly or chunky jointed. Phenocrysts: $1-2 \%$ plag $(1-4 \mathrm{~mm})$; sparse olivine microphenocrysts (rarely $>0.5 \mathrm{~mm}$ ); and rare $1-\mathrm{mm} \mathrm{cpx}$. Unit may represent a phenocryst-depleted, slightly 
more evolved, second stage of subjacent eruptive unit bth; their vents are only $300 \mathrm{~m}$ apart and aligned north-south, nearly normal to axis of the anticline they drape. Overlies only unit bth. Overlain by unit bnf $(1,533 \pm 3 \mathrm{ka})$. Undated. [MB]

btw Basalt west of Tannawasha Pasture (Pliocene)—Moderately phenocryst-rich lava flows and ejecta (50.5-53.3\% $\mathrm{SiO}_{2}$ ) of Cone 3302, between Dry and Spring Creeks $3 \mathrm{~km}$ west of Bergie Springs. Subdued cone is $\sim 1 \mathrm{~km}$ wide, $45 \mathrm{~m}$ high, and grades northeast into a lavaflow apron that crops out discontinuously for $8 \mathrm{~km}$ eastward along south rim of Spring Creek. Cone consists of red scoria (with bombs as big as $1 \mathrm{~m}$ ) and is capped by oxidized agglutinate, which is cut by a comagmatic dike that is massive, $4-7 \mathrm{~m}$ thick, vertical, and strikes $160^{\circ}$. Flows are commonly vesicular or massive and mottled; typically slabby or block jointed as canyon rimrocks, they weather to rounded blocks on plateau surfaces. Medially, two flows crop out as ledges, each $10-15 \mathrm{~m}$ thick, but distally there is a single rimrock flow 5-10 $\mathrm{m}$ thick. Phenocrysts: wide range $(2-15 \%)$ in plag content $(0.5-4 \mathrm{~mm})$, more abundant on and near cone; $1-4 \% \mathrm{cpx}(1-3 \mathrm{~mm})$, commonly exceeding plag; sparser olivine $(0.5-2 \mathrm{~mm})$. Overlies units Tcr and $\mathbf{m t w}$. Contact relation with unit bys $(3,708 \pm 37$ ka) uncertain. Overlain by unit bta $(3,464 \pm 4 \mathrm{ka})$. May be of approximately same age as adjacent cone of compositionally similar unit bbw. ${ }^{40} \mathrm{Ar} /{ }^{39} \mathrm{Ar}$ age: $4,027 \pm 61 \mathrm{ka} .[\mathrm{LCF}]$

bub Trachybasalt of upper Blue Creek (early Pleistocene)—Phenocryst-poor ejecta (48.3-50.7\% $\mathrm{SiO}_{2}$ ) of 60-m-high scoria Cone 3408 and associated lava flows, adjacent to Vessey Springs Road in headwaters of Blue Creek. Scoria lapilli, blocks, and bombs are finely to coarsely vesicular, non-agglutinated, and generally oxidized. Lava-flow apron crops out nearby to north and west but is largely covered by younger units. Phenocrysts: almost aphyric; trace amounts of tiny olivine and plag $(0.5-1 \mathrm{~mm})$ are present locally, as are rare fragments $(1-10 \mathrm{~mm})$ of plag megacrysts. Base not exposed. Overlain by units bnb $(1,328 \pm 2 \mathrm{ka})$, bnt, and bus. Undated. [HB]

bus Basalt of upper Sheep Creek (early Pleistocene)—Moderately phenocryst-rich lava flows $\left(48.8-49.0 \% \mathrm{SiO}_{2}\right)$ and ejecta $\left(46.8 \% \mathrm{SiO}_{2}\right)$ erupted at 1-km-wide scoria cone centered $\sim 2 \mathrm{~km}$ southwest of Sheep Butte. Cone, $\sim 80 \mathrm{~m}$ high, variously consists of loose, tackwelded, or moderately agglutinated ejecta. On steep northeast slope denser agglutinate is eroded into cliffy knobs with $10 \mathrm{~m}$ of local relief. Cone may be an element of a northwesttrending fissure vent that earlier fed adjacent unit bwp. Apron of lava flows descends $2 \mathrm{~km}$ southwest to headwaters of Blue Creek and $3 \mathrm{~km}$ northwest to upper Sheep Creek. Phenocrysts: $\sim 5 \%$ plag (1-3 mm), abundant small olivine $(0.3-1 \mathrm{~mm})$, and sparse but ubiquitous cpx (1-4 mm). Rare plag megacrysts as big as $8 \mathrm{~mm}$ are irregularly distributed. Overlies units bnb (1,328 $2 \mathrm{ka})$, bns $(1,566 \pm 3 \mathrm{ka})$, bnt, bub, and bwp. Overlain by units bsb and bst. Undated. [HB]

but Trachybasalt of upper Twentyfive Mile Creek (early Pleistocene or Pliocene)—Distinctive lava flows $\left(49.2 \% \mathrm{SiO}_{2}\right)$ rich in coarse plagioclase crystals, cropping out as 1-km-long swath in headwaters of Twentyfive Mile Creek. Inferred to have erupted at vent cluster northwest of Stagman Butte, but its own vent is concealed by products of three younger units. Lava flows decay to grussy knobs, slabs, rounded boulders, and ledges marked by cavernous weathering. Phenocrysts: $30-40 \%$ plag $(1-15 \mathrm{~mm})$, common olivine $(0.5-1 \mathrm{~mm})$, and cpx (which, although sparse, includes megacrysts as big as 20-30 mm). Elevated $\mathrm{Al}_{2} \mathrm{O}_{3}$ content ( $22 \%$ ) supports interpretation of unit as originating by eruption of feldspar-rich cumulate mush. Base not exposed. Overlain by units bnt, bnw, and bsm (2,056 $25 \mathrm{ka})$. Undated. $[\mathrm{HB}]$

buw Trachybasalt of upper White Creek (Pliocene) - Aphyric lava flows (47.3-47.5\% $\mathrm{SiO}_{2}$ ) exposed as 2-km-long strip along floor and west wall of upper White Creek. Crops out as ledges, joint blocks, and slabs, generally massive, and as weathered blocks in thick loessic soil. Vent presumed buried to north; unit may be an early batch related to overlying unit bsz, which is slightly more evolved, not quite aphyric, and inferred to have erupted beneath Lincoln Plateau. Phenocrysts: generally none, though rare fragments of plag megacrusts are present distally. Base not exposed. Overlain by units b84, blo, bsz (3,323 $\pm 6 \mathrm{ka})$, and $\mathbf{~ m s k}$ $(3,685 \pm 143 \mathrm{ka})$. Undated. [PB]

bw Basalt and trachybasalt of White Creek (early Pleistocene) - Apron of phenocryst-poor lava flows (46.7-47.6\% $\mathrm{SiO}_{2}$ ) that emerges from beneath Poland Butte (unit bpo) and extends $\sim 7$ $\mathrm{km}$ southwest along rim of White Creek gorge. Source vent covered by younger units, but 
many samples are compositionally similar to those of Simon Butte (unit bsi). Unit is 30-50 $\mathrm{m}$ thick along rim of White Creek and as thick as $90 \mathrm{~m}$ on west wall of Brush Creek. Ledges that crop out on scree-mantled slopes suggest most flows are 5-15 m thick. Slabby to blockjointed flows are typically aphyric with mottled granular groundmass commonly studded with tiny olivine $(0.1-0.3 \mathrm{~mm})$ or less commonly with traces of cpx. Rare phenocrysts of olivine $(0.5-1 \mathrm{~mm})$ and plag laths $(1-5 \mathrm{~mm}$ long) were observed locally. Still rarer are olivine-plag clots (to $15 \mathrm{~mm}$ ) and intergrown cpx-olivine-plag fragments $(5-15 \mathrm{~mm}$ ); scattered fragments of plag megacrysts $(1-10 \mathrm{~mm})$ are sparse but locally in swarms. Overlies units Tcr, bpc $(3,325 \pm 23 \mathrm{ka})$, and $\mathbf{b s h}(3,251 \pm 7 \mathrm{ka})$. Overlain by units bbl $(1,687 \pm 5 \mathrm{ka}), \boldsymbol{b c r}(1,513 \pm 4 \mathrm{ka})$, boh $(981 \pm 14 \mathrm{ka})$, bpo $(1,101 \pm 3 \mathrm{ka}), \boldsymbol{b s r}(1,685 \pm 11 \mathrm{ka})$, b63, b73, b94, and $\mathbf{m t c} .{ }^{40} \mathrm{Ar} /{ }^{39} \mathrm{Ar}$ age: $1,885 \pm 5 \mathrm{ka}$. [TB, PB]

bwb Basalt of Wellenbrock Spring (Pliocene) - Olivine-rich basaltic (51.6-52.9\% $\mathrm{SiO}_{2}$ ) lava flows of 8-km-wide shield volcano centered at Hill $3056,1.5 \mathrm{~km}$ south of map edge. Numerous shingled flows are deeply weathered and covered by thick rubbly colluvium and loessic soil charged with rounded boulders and corestones. Phenocrysts: abundant olivine (mostly $\leq 0.5$ but as big as $2 \mathrm{~mm}$ ), commonly in clusters; in most flows phenocrystic plag is rare, but plag microphenocrysts, microlites, and ill-formed aggregates are conspicuous, especially in weathered rocks. Rests on unit Tcr. Unit bof $(967 \pm 4 \mathrm{ka})$ banks around foot of shield. K-Ar

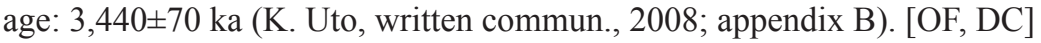

bwc Basalt of Wilson Charley Canyon Road (Pliocene) - Moderately phenocryst-rich lava flows $\left(46.5-50.1 \% \mathrm{SiO}_{2}\right)$ preserved as eroded remnants in headwaters of Kusshi Creek and Wilson Charley Canyon. Vent buried to west beneath shield lavas of unit msr. Lava flows crop out as massive or vesicular blocks and slabs. Package of fairly heterogeneous flows is as thick as $50 \mathrm{~m}$ on steep western slopes but generally only $10-15 \mathrm{~m}$ on easterly ridges and plateaus. Phenocrysts: generally $5-10 \%$ total phenocrysts but either olivine or plag may dominate, ranging from $2 \%$ to $8 \%$ each; cpx $(1-2 \mathrm{~mm})$ is typically present but sparse. Olivine is either abundant and tiny $(\leq 0.5 \mathrm{~mm})$ or sparsely scattered and $1-2 \mathrm{~mm}$. Most plag is $1-4 \mathrm{~mm}$ but rare megacrysts are as big as $10 \mathrm{~mm}$. At base of unit, a feldspar-rich basaltic lava flow (49.1\% $\mathrm{SiO}_{2}$ ) is exposed as a 600-m-long swath (subunit bwc') that crosses Wilson Charley Canyon Road at elevation 3,540 ft and banks against a rhyolite knob of unit rkc. Subunit contains $15-20 \%$ plag $(1-3 \mathrm{~mm})$ and a trace of tiny olivine, and it appears to grade up into main unit bwc, of which it may be a variant enriched in cumulate feldspar mush entrained during eruption. Both main unit and subunit rest on unit Tcr and an irregular paleosurface of knobby rhyolite unit rkc. Overlain by units bkc, mkc, and $\mathbf{m s r}(3,465 \pm 4$ ka). Undated. [LCSW]

bwd Trachybasalt of White Deer Road (early Pleistocene or Pliocene)—Phenocryst-poor lavaflow remnant $\left(47.7 \% \mathrm{SiO}_{2}\right), 350 \times 750 \mathrm{~m}$ across, that forms isolated knoll $\sim 1 \mathrm{~km}$ north of South Fork Toppenish Creek. Eroded knoll is block jointed and massive, locally weakly vesicular. Vent presumed to lie north or northwest of map area. Phenocrysts: sparse plag $(1-10 \mathrm{~mm})$, rare 1-mm olivine, and still rarer 1-mm cpx. Rests on units bwr and $\mathbf{m s p}$ $(3,286 \pm 6 \mathrm{ka})$. Undated. [PB]

bwe Basaltic trachyandesite east of White Creek (Pliocene)—Phenocryst-poor lava flows (52.3$53.7 \% \mathrm{SiO}_{2}$ ) that crop out for $\sim 2 \mathrm{~km}$ along east rim of White Creek gorge. At least two massive flows, each 15-20 m thick, separated by vesicular zone; block jointed or slabby, locally platy. Source vent unknown; possibly far upstream. Phenocrysts: generally aphyric but carries very sparse olivine $(0.5-1 \mathrm{~mm})$ and rare fragments of plag $(5-10 \mathrm{~mm})$. Overlies unit bpc $(3,325 \pm 23 \mathrm{ka})$. Overlain by unit btb $(3,262 \pm 5 \mathrm{ka})$. Unit bcr $(1,513 \pm 4 \mathrm{ka})$ banks against it on canyon wall. Undated. [TB]

bwf Basalt west of White Fir Creek (early Pleistocene) - Phenocryst-poor lava flows and ejecta (47.5-48.6\% $\mathrm{SiO}_{2}$ ) erupted at site of 60-m-high scoria cone $4 \mathrm{~km}$ east of McKays Butte. Low-relief lava apron extends $2 \mathrm{~km}$ southwest and $3 \mathrm{~km}$ northeast, nearly to Camas Patch meadows. Cinder quarry in cone exposes stratified red scoria-fall deposit, generally weakly agglutinated; even largest meter-scale blocks are oxidized and at least modestly vesicular. Flows are massive or vesicular, commonly disintegrating as rounded joint blocks in thick loessic soil. Phenocrysts: $<1 \%$ olivine $(0.5-2 \mathrm{~mm}$; rarely to $4 \mathrm{~mm})$, some in clusters; $3-5 \%$ plag (2-4 mm) plus rare fragments of plag megacrysts $(5-12 \mathrm{~mm})$; and rare cpx $(0.5-1 \mathrm{~mm})$. Overlies units $\mathbf{t 3 9}$, b39, bem, b90, and bcs (1,882 $\pm 48 \mathrm{ka})$. Overlain by units b36, bgs $(1,531 \pm 4 \mathrm{ka})$, and bgs'. Undated. [MB, CP] 
bwg Basalt west of Garner Camp (Pliocene)-Olivine-rich lava flow $\left(47.2 \% \mathrm{SiO}_{2}\right)$ that crops out $\sim 500$ m west of Garner Camp as a 300-m-wide swath that extends $\sim 1 \mathrm{~km}$ southward toward Bowman Creek. Flow crops out as massive ledges and joint blocks through colluvial rubble. Phenocrysts: $\sim 10 \%$ olivine (1-2 $\mathrm{mm}$ ) with tiny spinel inclusions; sparse cpx; and rare plag. Little incised; base not exposed but probably rests on unit Tcr (which crops out nearby). Chemically and lithologically similar to flows of unit bos (3 km northwest) and to olivinerich flows within unit bld (3-4 km east), both of which rest on unit Tcr. Overlain by units bpb ( $822 \pm 3 \mathrm{ka})$ and, south of map edge, by unit b58 (700 $\pm 30 \mathrm{ka})$. Undated. [HB, WPB]

bwh Trachybasalt of White Deer Creek (Pliocene) - Moderately porphyritic lava flows (47.9$48.6 \% \mathrm{SiO}_{2}$ ) that crop out for $\sim 8 \mathrm{~km}$ along White Deer Creek. Distinctive unit, rich in olivine and cpx, is seldom thicker than $30 \mathrm{~m}$ as rimrock along canyons of White Deer and South Fork Toppenish Creeks; it thins northward to ledges only 3-10 m thick at north rim of South Fork and also thins westward toward divide between White Deer and White Creeks, where unit has been uplifted $\sim 80 \mathrm{~m}$ on Mike Coon Anticline. Source vent presumed buried beneath unit msp, between South Fork and upper White Deer Creek. Crops out as massive, block jointed, slabby, or hackly ledges and knobs, typically disintegrating to rough-surfaced rounded blocks, commonly 1-3 $\mathrm{m}$ in diameter. A narrow strip, $50 \mathrm{~m}$ long, of shattered blocks of unit bwh resting on sharp divide (at elevation 2,730 ft) near confluence of White Deer and Toppenish Creeks might be an intracanyon remnant but more likely a landslide mass, $110 \mathrm{~m}$ lower than base of unit on rim above. Phenocrysts: varied proportions of cpx, olivine, and plag; either cpx or olivine typically dominates; plag ranges from rare to locally abundant, generally sparser westward. Ranges observed: $3-10 \%$ olivine $(1-5 \mathrm{~mm}) ; 1-5 \%$ cpx (1-15 mm); 0-8\% plag, mostly $1-5 \mathrm{~mm}$, plus fragments (3-20 $\mathrm{mm})$ of plag megacrysts. Samples with $10-11 \% \mathrm{MgO}$ are olivine-accumulative; most have only $5.5-8 \% \mathrm{MgO}$. Overlies units Tcr, btp, bew, and bsz (3,323 $\pm 6 \mathrm{ka})$. Overlain by units boc $(2,136 \pm 5 \mathrm{ka})$, bwt, and $\mathbf{m s p}(3,286 \pm 6 \mathrm{ka})$. Undated. [PB, MB]

bwi Trachybasalt of West Indian Rock (Pliocene) - Phenocryst-rich lava flows and ejecta (50.0 $51.4 \% \mathrm{SiO}_{2}$ ) that crop out at southeast end of Lakebeds but extend at least $1 \mathrm{~km}$ southeast of map edge to apparent vent at Crag 5819, informally called West Indian Rock, which stands $500 \mathrm{~m}$ northwest of Indian Rock. Crag is $\sim 20 \mathrm{~m}$ in diameter and $8 \mathrm{~m}$ high, massive or locally vesicular, and coarsely jointed (both blocky and hackly). As its periphery is strewn with oxidized scoria as coarse as $40 \mathrm{~cm}$, it is probably a deeply eroded plug. Lava flows between crag and Lakebeds are block jointed and rich in large plagioclase crystals. Phenocrysts: abundant plag (1-25 mm) and common olivine (1-3 mm). Probably overlies unit dni. Probably overlain by units bld (3,841 $\pm 14 \mathrm{ka})$ and b59. K-Ar age: 3,990 $\pm 40 \mathrm{ka}$ for lava just southeast of plug (K. Uto, Geological Survey of Japan, written commun., 2008). [SB, IR]

bwk Trachybasalt west of West Fork White Creek (early Pleistocene)-Plagioclase-rich lava flows (48.0-48.6\% $\mathrm{SiO}_{2}$ ) along divide between northern headwaters of Trout Creek and West Fork White Creek. Supports bold knobby outcrops that decay into piles of coarse rounded boulders; mostly massive, rarely vesicular. Phenocrysts: 25-30\% plag (1-15 mm); sparse olivine $(0.5-1 \mathrm{~mm})$. May have been coextrusive with overlying phenocryst-poor unit bly, as age relations at contacts are equivocal and units appear locally to intergrade through intermediate lithology with 5-10\% plag; moreover, near contacts, phenocryst-poor rock locally encloses $10-\mathrm{m}$-scale domains rich in plag. Vent probably concealed by fissure-vent system of unit bly. North end of unit may have been elevated $\sim 80 \mathrm{~m}$ by uplift of Peavine Ridge Anticline. Overlies units Tcr, bpr, and b97. Overlain by units bsr $(1,685 \pm 11 \mathrm{ka})$ and bly $(1,697 \pm 20 \mathrm{ka})$. See description of unit bly for discussion of its probable partial coeruption with unit bwk. Undated but age presumed similar to that of unit bly. [SP, PB]

bwl Trachybasalt of Wall Canyon (early Pleistocene) - Nearly aphyric lava flows $\left(49.3 \% \mathrm{SiO}_{2}\right)$ that crop out for only $\sim 500 \mathrm{~m}$ along west-bank tributary gorge (UTM 685/181) at northwest end of Wall Canyon on North Fork Dry Creek. One or more slabby flows altogether only $15-20 \mathrm{~m}$ thick. Phenocrysts: far less than $1 \%$ total crystals; rare olivine as big as $1 \mathrm{~mm}$; rare fragments of shattered plagioclase. Rests on unit Tcr. Overlain by unit bsf $(2,060 \pm 10 \mathrm{ka})$. Undated. [CP]

bwp Basalt west of Poker Spring (early Pleistocene)—Phenocryst-rich ejecta and fountain-fed lava flows (47.8-48.0\% $\mathrm{SiO}_{2}$ ) of northwest-trending fissure-fed ridge $2 \mathrm{~km}$ southwest of Sheep Butte and adjacent to scoria-cone vent of unit bus. Scoria, brick-red agglutinate, 
and massive to slightly vesicular, block-jointed lava flows are all strikingly unusual in containing $\sim 10 \%$ each of olivine and cpx (both 5-10 mm) but almost no plag. Also contrasts with adjacently erupted unit bus in being far richer in $\mathrm{Mg}$ and $\mathrm{Ca}$ but poorer in $\mathrm{Al}$ and $\mathrm{Na}$, presumably owing to accumulation of mafic crystals. Base not exposed. Overlain by units bst and bus. Undated. [HB]

bwr Trachybasalt and basaltic trachyandesite of West Road (Pliocene)-Aphyric lava flows $\left(50.5-52.5 \% \mathrm{SiO}_{2}\right)$ that extend from canyon of South Fork Toppenish Creek across plateau for $2 \mathrm{~km}$ northward and for $>3 \mathrm{~km}$ northwestward beyond map edge. Crops out as massive blocks and slabs and as block-jointed ledges and rimrock at canyons, rarely vesicular but commonly weathered pale gray and punky. Erupted on Lincoln Plateau, north of map area, and accordingly is probably a slightly more evolved phase of lithologically similar unit blp. Phenocrysts: none. Distinguished from overlying aphyric unit $\mathbf{m s p}$ by scarcity of obvious plag microlites, which are conspicuous in $\mathbf{m s p}$ flows. Overlies units Tcr, bsz $(3,323 \pm 6 \mathrm{ka})$, and bwt. Overlain by units bwd and $\mathbf{m s p}(3,286 \pm 6 \mathrm{ka})$. Undated, but apparently related unit blp gave ${ }^{40} \mathrm{Ar} /{ }^{39} \mathrm{Ar}$ age of $3,278 \pm 4 \mathrm{ka}$. [PB, WHP]

bws Trachybasalt west of Stagman Butte (early Pleistocene)-Nearly aphyric lava flows (49.249.7\% $\mathrm{SiO}_{2}$ ) erupted from small shield capped by Hill 4291, $2.5 \mathrm{~km}$ west of Stagman Butte. Shield is $1.5 \mathrm{~km}$ in diameter and has $180 \mathrm{~m}$ total relief; its summit includes minor agglutinate but mostly massive nonvesicular lava flows, broken into joint blocks and slabs. From west base of shield, flows are exposed for $2 \mathrm{~km}$ westward along Twentyfive Mile Creek, and a southwestern tongue (extensively covered by younger units) extends $4 \mathrm{~km}$ to Summit Creek. Distal flows are massive and block jointed, locally weakly vesicular, and decay into rounded boulders in thick loessic soil. Phenocrysts: typically none. Sparse fragments as big as $10 \mathrm{~mm}$ of plag megacrysts and very rare olivine $(2-3 \mathrm{~mm}$, possibly antecrystic) are present locally, as are rare sugary aggregates of sub-millimeter plag. Plag microlites commonly impart sheen to joint faces. Overlies unit bsm $(2,056 \pm 25 \mathrm{ka})$. Overlain by units bfc ( $681 \pm 2 \mathrm{ka})$, bnk, bnt, and byc. Undated. [HB]

bwt Trachybasalt west of Toppenish Creek (Pliocene)—Aphyric lava flows (47.4-48.2\% $\mathrm{SiO}_{2}$ ) that form rim and upper walls of lower South Fork and west rim of main fork of Toppenish Creek for $6 \mathrm{~km}$ north of their confluence. Flows are massive, block jointed, slabby, or locally platy; commonly mottled and tend to weather pale gray. In common with chemically similar but younger aphyric unit boc $(2,136 \pm 5 \mathrm{ka})$, vent area is north of map area, probably on or east of Lincoln Plateau. Phenocrysts: none. Groundmass olivine is typically conspicuous but crystals larger than $0.4 \mathrm{~mm}$ are rare. Plag normally absent but rare crystals have been observed. Overlies units Tcr and bwh. Overlain by units bwr and $\mathbf{m s p}(3,286 \pm 6 \mathrm{ka})$. Undated. [PB, LHP]

bww, Basalt west of Wilson Charley Canyon (early Pleistocene or Pliocene)—Olivine-rich lava bww' flows (48.1-49.5\% $\mathrm{SiO}_{2}$ ) as thick as $30 \mathrm{~m}$ preserved as several remnants along west wall of Wilson Charley Canyon for $\sim 4.5 \mathrm{~km}$, as far as its confluence with Satus Creek. Although unit veneers extensive slopes, it appears to represent no more than two lava flows. West of Highway 97 near confluence of Wilson Charley Canyon and Satus Creek, unit supports a bench (at elevation 2,450 ft) with a 15-m rim scarp that overlies a stack of thin flows of unit bsa. Forms ledges and block-jointed or slabby surfaces, generally massive or locally slightly vesicular. Source vent not identified. Phenocrysts: fairly heterogeneous; either olivine or plag may dominate; $5-10 \%$ olivine $(0.5-2 \mathrm{~mm}) ; 2-8 \%$ plag $(1-6 \mathrm{~mm})$; and sparse cpx $(1-3 \mathrm{~mm})$. Rare megacrysts of plag and cpx are each as big as $10 \mathrm{~mm}$. A single lava flow $\left(49.6 \% \mathrm{SiO}_{2}\right)$, designated subunit bww', 5-15 m thick, forms middle of three ledges along west wall of lower Wilson Charley Canyon, sandwiched between unit bsa below and main unit bww on top; its abundant plag (3-6 mm) and sparse olivine distinguish it from most of chemically similar unit bww. Overlies units Tcr and bsa; one remnant banks against unit rwc. Overlain by unit bkc. Undated. [LCSW]

bxc Trachybasalt of Section Corner Creek (early Pleistocene or Pliocene)—Three discrete masses of exceptionally plagioclase-rich basalt $\left(48.0-48.9 \% \mathrm{SiO}_{2}\right)$ enclosed by and overlying lavas of unit $\mathbf{m x c}$, probably representing mushy cumulates withdrawn along with phenocryst-poor magma of unit $\mathbf{m x c}$. Bold knobby outcrops disintegrate to coarsely grussy, rounded blocks with rough, feldspar-studded surfaces. Exposed relief as little as a few meters or as great as $15 \mathrm{~m}$ where capping hilltops. Phenocrysts: $20-35 \%$ plag $(2-25 \mathrm{~mm})$ and sparse olivine 
( $1 \mathrm{~mm}$, rarely as big as $3 \mathrm{~mm})$; cpx absent or rare (1-3 mm). Rests on unit $\mathbf{m x \mathbf { c }}$ wherever base can be inferred; elsewhere appears to be surrounded by $\mathbf{m x c}$. Also overlies unit mcc. Overlain by unit byt $(674 \pm 4 \mathrm{ka})$. Undated. [SB, LCSW]

byc Trachybasalt of Yeackel Camp (middle or early Pleistocene)—Phenocryst-poor lava flows and ejecta (47.4-47.8\% $\mathrm{SiO}_{2}$ ) produced at twin scoria cones separated by Kinney Creek, $2 \mathrm{~km}$ northwest of Potato Butte. Cones are centered $600 \mathrm{~m}$ apart, aligned north-south, and each is $40-50 \mathrm{~m}$ high and $\sim 500 \mathrm{~m}$ wide; both consist predominantly of loose scoria, locally agglutinated. Southern cone is intruded by a microgabbroic plug $\sim 100 \mathrm{~m}$ in diameter, which is medium grained, holocrystalline, and contains sparse plag phenocrysts as big as $10 \mathrm{~mm}$, as well as irregularly scattered vugs. Each cone grades outward into an apron of fountain-fed lava flows that extends $4 \mathrm{~km}$ westward to confluence of Summit and Kinney Creeks. Scoria, lava flows, and plug are all of similar composition. Phenocrysts: only traces of olivine, plag, and cpx - each mostly microphenocrystic but rarely as big as $1 \mathrm{~mm}$. Plag microlites are conspicuous in weathered groundmass. Overlies units bld ( $3,820 \pm 57 \mathrm{ka})$, bos, bpb ( $822 \pm 3 \mathrm{ka})$, and bws. Overlain by units bfc ( $681 \pm 2 \mathrm{ka})$ and bnk. Undated. [HB]

bys Basalt of South Fork Yatama Creek (Pliocene)-Moderately phenocryst-rich lava flows (48.0-50.1\% $\left.\mathrm{SiO}_{2}\right)$ that emerge from beneath shield of unit $\mathbf{m s r}$ in upper South Fork Yatama Creek and extend $12 \mathrm{~km}$ northeast. They form both rims of Black Canyon on lower Yatama Creek and both rims of Logy Creek below their confluence, feathering out $\sim 3 \mathrm{~km}$ east of Logy Creek Falls to a single plateau-capping flow. Maximum thickness exposed is $25-30 \mathrm{~m}$ medially, but distal rimrock exposures are only 3-15 m thick. Plateau surfaces and rim scarps are slabby, hackly, or block jointed, and in places vesicular. At distal extremity on promontory between Tenie and Logy Creeks, flow is slabby to thinly platy and its flow foliation recumbently folded (despite subalkaline composition). Rimrock remnant that stretches $3 \mathrm{~km}$ along northwest rim of Logy Creek gorge (at same elevation as plateau on southeast rim) demonstrates emplacement of unit prior to canyon incision. Source vent is buried by younger units on main shield to southwest. Phenocrysts: $5-10 \%$ plag $(1-2 \mathrm{~mm}$, rarely $6 \mathrm{~mm}), 2-5 \%$ olivine $(\leq 1 \mathrm{~mm})$, and sparse $1-\mathrm{mm} \mathrm{cpx}$. On distal plateaus (where one or two flows are exposed), unit also contain conspicuous vesicular clots (5-20 mm) of cpx+olivine+plag microphenocrysts. Overlies unit Tcr. Unit rtc may be intercalated between flows of unit bys. Overlain by units b41, bsl $(776 \pm 2 \mathrm{ka})$, bta $(3,464 \pm 4 \mathrm{ka})$, bte, byt $(674 \pm 4 \mathrm{ka})$, and $\mathbf{m s r}(3,465 \pm 4 \mathrm{ka}) \cdot{ }^{40} \mathrm{Ar} /{ }^{39} \mathrm{Ar}$ age: $3,708 \pm 37 \mathrm{ka}$. [LCSW, LCF, LCNE]

byt Trachybasalt of Yatama Creek (middle Pleistocene)—Moderately phenocryst-rich lava flows and ejecta (48.6-49.9\% $\mathrm{SiO}_{2}$ ) erupted at Tadpole Lake scoria cone and associated fissure vent. Lava-flow apron descends northeast and east from cone, dividing into a northerly lobe that extends $5 \mathrm{~km}$ between Logy and Section Corner Creeks and a narrow intracanyon tongue that extends $15 \mathrm{~km}$ northeastward down Yatama Creek to Logy Creek Falls, beyond which two flow units continue an additional $13 \mathrm{~km}$ down Logy Creek as a series of 25 remnants preserved as benches on both banks. Tadpole Lake, $250 \mathrm{~m}$ wide and only a mudflat in dry season, occupies shallow crater surrounded by rim of oxidized ejecta 5-10 m higher than lake, except $\sim 35 \mathrm{~m}$ on southwest side. Scoria cone, $\sim 1.2 \mathrm{~km}$ in diameter, has $75 \mathrm{~m}$ relief on north, $200 \mathrm{~m}$ on east, and (because built on steep paleoslope) hardly any relief on southwest. A fissure vent just north of cone trends N. $60^{\circ} \mathrm{E}$. and is marked by weakly to moderately welded oxidized agglutinate, which contains scoria lapilli, blocks, and bombs (some flattened) as big as $2 \mathrm{~m}$, eroded into ragged knobs and ridges. Greatest thickness exposed is $\sim 30 \mathrm{~m}$ where massive lava flows form both walls of Yatama Creek and its North Fork. Downstream from Logy Creek Cow Camp (which is located on Yatama Creek), unit becomes a narrow intracanyon ridge $50 \mathrm{~m}$ wide and 10-25 m high, inset below ledgy walls of units bys and Tcr. Downstream along Logy Creek canyon, two persistent flow units are each 7-12 m thick, variously columnar, hackly, or block jointed, and have rubbly scoriaceous basal zones locally exposed. Along Logy Creek, base of most of the 25 remnants is close to stream level, whereas top of flow pair stands as high as $40 \mathrm{~m}$ above creek upstream but only 10-25 m downstream. Phenocrysts: typically $>10 \%$ proximally and medially, declining distally to $<5 \%$. Common plag $(1-3 \mathrm{~mm})$ plus irregularly distributed fragments of plag megacrysts $(5-20 \mathrm{~mm}$; rarely $40 \mathrm{~mm})$; common olivine $(0.5-3 \mathrm{~mm})$; cpx rare distally but common proximally $(0.5-6 \mathrm{~mm})$. Also present proximally are rare angular 
inclusions of coarsely intergrown plag and pyroxene. Younger than all contiguous units.

${ }^{40} \mathrm{Ar} /{ }^{39} \mathrm{Ar}$ age: $674 \pm 4 \mathrm{ka}$. [SB, LCSW, LCF, LCNW]

b00 Trachybasalt of Cone 3600 (early Pleistocene)-Phenocryst-poor ejecta $\left(48.2 \% \mathrm{SiO}_{2}\right.$ ) of small scoria cone, only $500 \mathrm{~m}$ wide and $30 \mathrm{~m}$ high, $2 \mathrm{~km}$ north of Hoppers Flat and $3 \mathrm{~km}$ east of Simon Butte. Lapilli and bombs, variously oxidized, are loose and vesicular, not agglutinated. Phenocrysts: sparse plagioclase $(<1 \mathrm{~mm}$, much of it partly resorbed) and sparser olivine $(\sim 0.5 \mathrm{~mm})$; plus widely scattered plag megacrysts $(10-20 \mathrm{~mm})$. Base not exposed. Overlain and surrounded by units b03, b37, and bmf, all of which contrast with unit b00 in containing cpx phenocrysts. Undated. [MB]

b01 Trachybasalt of Cone 3801 (Pliocene) -Asymmetrical shield volcano, $2 \mathrm{~km}$ wide, of phenocryst-poor lava flows and ejecta $\left(47.5-49.0 \% \mathrm{SiO}_{2}\right)$, capped by small spatter cone. Erupted on southwest flank of Mike Coon Hillside Anticline. Agglutinate caps cone; lavaflow apron crops out as massive ledges, block jointed to slabby. Northeasterly ridge of knobs and crags, massive to slightly vesicular, culminates at an elevation $\sim 30 \mathrm{~m}$ higher than source vent, apparently elevated by continued growth of anticline. Phenocrysts: generally aphyric, except near southwest flow front, where sparse olivine and plag (each 1-3 mm) and rare fragments of plag megacrysts (to $10 \mathrm{~mm}$ ) are present. Overlies units Tcr, bsz $(3,323 \pm 6 \mathrm{ka})$, and b84. Overlain by units $\mathbf{b} 32$ and $\mathbf{m 9 3}$. Undated. [PB]

b03 Basalt of Cone 4003 (early Pleistocene) - Phenocryst-rich ejecta and minor fountain-fed lava flows (46.7-48.2\% $\mathrm{SiO}_{2}$ ) of 120-m-high scoria cone (Hill 4003), $\sim 1 \mathrm{~km}$ wide, centered $3 \mathrm{~km}$ east of Simon Butte. Dense but knobbly agglutinate caps summit, and small bench at north toe of cone was built by similar spatter-fed lava. Slopes elsewhere are strewn with loose scoria, mostly phenocryst-rich but including a subordinate scoria population that has $<5 \%$ phenocrysts and is compositionally slightly more evolved. Phenocrysts: $20-25 \%$ total; cpx, olivine, and plag all common but in varied proportions, with either olivine or plag dominant. Olivine (1-2 mm); plag (1-4 mm plus megacrysts to $10 \mathrm{~mm})$; cpx (1-5 mm) locally exceeds olivine where plag dominates. Overlies units b00, b37, and bmf. Overlain by unit bnf $(1,533 \pm 3 \mathrm{ka})$. Undated. [MB]

b10 Trachybasalt of Cone 3010 (middle or early Pleistocene)-Moderately porphyritic scoria cone and westerly lava-flow apron $\left(47.4-48.1 \% \mathrm{SiO}_{2}\right)$ that overlies northwest toe of Oak Hill Shield. Scoria cone is $60 \mathrm{~m}$ high, consisting mostly of oxidized cinders but including bombs as big as $80 \mathrm{~cm}$, many with dense dark-gray cores. Lava apron to west, $\sim 1 \mathrm{~km}$ both wide and long, consists of massive blocks exposed poorly through thick loessic soil. Phenocrysts: $5-8 \%$ plag (mostly $1-5 \mathrm{~mm}$, plus rare megacrysts as big as $10 \mathrm{~mm}$ ); $1-3 \%$ olivine $(\leq 1 \mathrm{~mm}$ ) and rare 3-mm olivine. Sparse gabbroic xenoliths as big as $10 \mathrm{~mm}$. Overlies units b29 $(1,420 \pm 4 \mathrm{ka}), \mathbf{b 3 0}$, b97, and boh ( $981 \pm 14 \mathrm{ka})$. Undated. [SP, PB]

b14 Basalt of Shield 3114 (Pliocene)-Moderately phenocryst-rich lava flows and ejecta (48.4$48.9 \% \mathrm{SiO}_{2}$ ) erupted at small shield volcano between Spring and Logy Creeks at southwest end of Tannawasha Pasture. Shield has $\sim 60 \mathrm{~m}$ relief and is as wide as $1 \mathrm{~km}$; its surface consists of oxidized scoria and agglutinate that grade outward into fountain-fed lava flows. Flow apron extends $4 \mathrm{~km}$ northeast along both rims of Logy Creek and $1.5 \mathrm{~km}$ north (beneath bta) to Spring Creek. Between creeks, flows cap a rubbly plateau marked by block-strewn meadows. On canyon rims, unit consists of 1-3 flows that crop out as massive block-jointed to slabby ledges with a combined thickness that decreases from 15-25 m proximally to $3-5 \mathrm{~m}$ distally. Phenocrysts: $10-15 \%$ plag $(1-5 \mathrm{~mm})$, common olivine (1-3 $\mathrm{mm}$ ), and sparse cpx (1-3 mm plus rare cpx megacrysts to $8 \mathrm{~mm}$ ). Overlies units Tcr and b41. Overlain by units bta $(3,464 \pm 4 \mathrm{ka})$, bls, and bsl ( $776 \pm 2 \mathrm{ka})$. Undated. [LCSW, LCF]

b22 Basalt of Cone 3122 (early Pleistocene) —Phenocryst-rich lava flows and ejecta (47.9-48.5\% $\mathrm{SiO}_{2}$ ) erupted from spatter cone just west of Tepee Creek, $3 \mathrm{~km}$ north of Poland Butte. Fissure vent extends $\sim 400 \mathrm{~m}$ southwest from cone. Agglutinate along crest is blobby to dense and mostly oxidized. Lava-flow apron extends $\sim 1 \mathrm{~km}$ southeast and crops out on both sides of Tepee Creek as ledges, slabby or block jointed. Total relief exposed is $\sim 70 \mathrm{~m}$. Phenocrysts: $10-15 \%$ olivine and $1-2 \% \mathrm{cpx}$, each 1-10 $\mathrm{mm}$; two populations of eachmegacrysts and phenocrysts; virtually no feldspar. Probably overlies unit b76. Overlain by units b33, bsi $(1,875 \pm 3 \mathrm{ka})$, and $\mathbf{m t c}$. Undated. [PB]

b23 Basalt of Cone 2823 (early Pleistocene or Pliocene)-Spatter cone (47.7-48.3\% $\left.\mathrm{SiO}_{2}\right) \sim 30 \mathrm{~m}$ high, at head of Schafer Creek, $2 \mathrm{~km}$ northeast of Twin Buttes. Cone is surrounded and 
isolated by younger flows of units bes and bbl. Loose scoria and agglutinate on top are flanked by slopes of spatter-fed stubby lava flows. Almost devoid of feldspar, having only very rare $1-\mathrm{mm}$ plag crystals. Contains $3-5 \%$ olivine $(1-2 \mathrm{~mm})$ and $\sim 1 \%$ pyroxene (mostly $1-2 \mathrm{~mm}$ but scattered cpx megacrysts are as big as $10 \mathrm{~mm}$ ). Both olivine and pyroxene commonly have reaction rims. Base not exposed. Overlain by units bes and bbl $(1,687 \pm 5 \mathrm{ka})$. Undated. [TB]

b27 Basalt of Cone 2784 (early Pleistocene or Pliocene) - Phenocryst-poor lava flows $\left(49.0 \% \mathrm{SiO}_{2}\right)$ of 60-m-high Cone 2784 and its adjacent lava-flow apron on southwest slope of Oak Hill, surrounded by younger flows of Oak Hill Shield (unit boh). Cone and apron both consist of massive block-jointed basalt; neither scoria nor nonhomogenized agglutinate was observed. Phenocrysts: $2-3 \%$ olivine $(0.5-1 \mathrm{~mm}$; rarely $2-3 \mathrm{~mm})$; sparse plag $(1-3 \mathrm{~mm})$, and rare plag megacryst fragments as big as $8 \mathrm{~mm}$. Overlies unit bso. Overlain by unit boh $(981 \pm 14 \mathrm{ka})$. Undated. [OF]

b29 Basalt and trachybasalt of Hill 2946 (early Pleistocene)—Phenocryst-rich lava flows and ejecta (48.0-49.3\% $\mathrm{SiO}_{2}$ ) erupted at arcuate scoria Ridge 2946 (northwest of Oak Hill). Vent ridge is mostly oxidized cinders but includes dark-gray bombs and dense blocks as big as $50 \mathrm{~cm}$. Tongue of lava flows extends $7 \mathrm{~km}$ southwest to Trout Creek. Massive to vesicular flows are well exposed only on canyon rims; exposure elsewhere consists of rubbly colluvium and corestones in thick loessic soil. Phenocrysts: plag content variably $5-10 \%$ (1-4 $\mathrm{mm}$, rarely $10 \mathrm{~mm}$ ); abundant olivine (1-3 $\mathrm{mm}$, rarely $10 \mathrm{~mm}$ ); sparse to common cpx (1-10 mm). Overlies units bpc $(3,325 \pm 23 \mathrm{ka}), \mathbf{b 6 8}$, and b97. Overlain by units boh (981 $\pm 14 \mathrm{ka})$ and b10. ${ }^{40} \mathrm{Ar} /{ }^{39} \mathrm{Ar}$ age: $1,420 \pm 4 \mathrm{ka}$. [SP, OF]

b30 Trachybasalt of Cone 3066 (early Pleistocene) - Scoria cone and lava-flow apron of aphyric basalt (48.5-49.2\% $\mathrm{SiO}_{2}$ ) on divide between Pole Creek and West Fork White Creek, centered $2 \mathrm{~km}$ north of Oak Hill. Scoria cone is $75 \mathrm{~m}$ high and consists of lapilli and bombs, mostly oxidized. Lava apron, exposed for $\sim 1 \mathrm{~km}$ south and southwest of the cone, consists of massive to vesicular joint blocks poorly exposed through thick loessic soil. Cone is one member of a compositionally varied but continuous north-south chain of small volcanoes between Oak Hill and Peavine Ridge Anticline; chain forms drainage divide between forks of White Creek to east and forks of Pole and Trout Creeks to west. Phenocrysts: none; microlite-rich groundmass contains abundant tiny olivine and plag. Older than contiguous unit b10; probably younger than adjacent unit b97. Undated. Units of associated vent alignment include boh ( $981 \pm 14 \mathrm{ka}), \mathbf{b 1 0}$, b62, b97, bwk, bly $(1,697 \pm 20 \mathrm{ka})$, and bsr $(1,685 \pm 11 \mathrm{ka})$. [SP, PB]

b31 Basalt of Cone 3185 (early Pleistocene)—Moderately porphyritic lava flows and ejecta (49.2\% $\mathrm{SiO}_{2}$ ) erupted at small spatter cone on west side of Tepee Creek near IXL Crossing Road. Lava apron crops out on both sides of Tepee Creek for $\sim 1 \mathrm{~km}$ south of the agglutinatecapped cone and as two small windows through unit bsi on east fork of Tepee Creek $1-1.5 \mathrm{~km}$ farther south. Flows are exposed as massive knobs and ledges, typically slabby or block jointed. Phenocrysts: abundant small olivine $(0.5-1.5 \mathrm{~mm})$; common plag $(1-3 \mathrm{~mm})$ plus shattered plag megacrysts as big as $10 \mathrm{~mm}$; and sparse 1-mm cpx. Overlies units a72 $(3,273 \pm 12 \mathrm{ka})$ and (probably) btc. Overlain by units b33 and bsi (1,875 $\pm 3 \mathrm{ka})$. Undated. [PB]

b32 Trachybasalt of Cone 3632 (early Pleistocene) — Aphyric lava flows and ejecta $\left(48.9 \% \mathrm{SiO}_{2}\right)$ erupted at asymmetrical spatter cone on south slope of Mike Coon Anticline, $\sim 2 \mathrm{~km}$ west of Tepee Creek. Southeast-trending fissure vent $\sim 500 \mathrm{~m}$ long is rimmed by agglutinate, dense along midline; loose cinders scattered on near-vent slopes and fountain-fed massive lava flows on lower slopes. Whole edifice is only $1 \mathrm{~km}$ wide; maximum relief $\sim 120 \mathrm{~m}$, on south slope. Phenocrysts: none. Overlies units Tcr, a72 (3,273 $\pm 12 \mathrm{ka}), \mathbf{b 0 1}$, and $\mathbf{~ m 9 3}$. No contiguous units are younger. Undated. [PB]

b33 Trachybasalt of Cone 3303 (early Pleistocene)-Moderately porphyritic lava flows and ejecta $\left(49.1 \% \mathrm{SiO}_{2}\right.$ ) erupted at small scoria cone $\sim 1 \mathrm{~km}$ west of Tepee Creek, just north of IXL Crossing Road. Cone is $\sim 600 \mathrm{~m}$ wide, has $\sim 35 \mathrm{~m}$ relief, and is strewn with loose oxidized cinders and scoria bombs. Lava flows crop out as massive block-jointed ledges that extend $\sim 3 \mathrm{~km}$ southward from cone to west bank of Tepee Creek, where distal flow locally displays prismatically jointed rosettes around a small collapsed lava tube. Phenocrysts: $7-10 \%$ plag $(1-5 \mathrm{~mm})$ plus scattered plag megacryst fragments as big as $25 \mathrm{~mm}$; common 1-mm olivine, 
b34

b36,

b36'

b37

b39

b41

b46 some in clusters; and sparse cpx (1-2 mm). Also contains rare diktytaxitic cpx-olivine-plag microgabbro enclaves (5-15 mm). Overlies units a72 (3,273 $\pm 12 \mathrm{ka}), \mathbf{a 7 2}$ ', b22, b31, b76, $\mathbf{m t c}$, and $\mathbf{m} 93$. Probably overlain by adjacent unit b46. Undated. [PB]

Trachybasalt of Cone 3401 (early Pleistocene) - Phenocryst-poor lava flows and ejecta (48.1-49.3\% $\mathrm{SiO}_{2}$ ) erupted at 60 -m-high spatter cone $\sim 2 \mathrm{~km}$ east of Hagerty Butte, midway between Blue and Twentyfive Mile Creeks. Cone is $1 \mathrm{~km}$ long, elongate northward and surrounded by younger units, which conceal outflow apron except for two windows northwestward along Blue Creek. Distal window exposed $3 \mathrm{~km}$ down Blue Creek (b34?) contains a little more olivine and plag and is chemically less evolved than the cone, but no alternative phenocryst-poor correlative is recognized. Blocks and slabs on cone and downstream are massive or slightly vesicular and contain only trace amounts of small olivine and plag $(\leq 0.5 \mathrm{~mm})$ and no megacrysts. No loose cinders or scoria bombs were found on cone, only agglutinate and fountain-fed flows. Base not exposed. Overlain by units bhb $(1,276 \pm 4 \mathrm{ka})$, bnb $(1,328 \pm 2 \mathrm{ka})$, bnk, and bnt; distal window also overlain by unit bbl $(1,687 \pm 5 \mathrm{ka})$. Undated. [HB]

Trachybasalt of Road Junction 3666 (early Pleistocene)—Plagioclase-rich lava-flow apron (47.2-48.6\% $\mathrm{SiO}_{2}$ ) fed from 600 -m-long fissure $\sim 1 \mathrm{~km}$ east of Graham Spring. Ruggedly eroded vent ridge consists of dense to knobbly agglutinate, and distal lava flows to north and west are eroded into bold block-jointed knobs and ledges. A 150-m-wide exposure of blockjointed massive basalt designated subunit b36', enclosed within east margin of unit, has far fewer phenocrysts but is chemically similar $\left(49.0 \% \mathrm{SiO}_{2}\right)$. Phenocrysts: variably $10-30 \%$ plag (3-20 mm); sparse olivine and rare cpx (both $\leq 1 \mathrm{~mm}$ ). Overlies units b39 and bwf. Overlain by unit bgs $(1,531 \pm 4 \mathrm{ka})$. Undated. [HB, MB]

Trachybasalt of Shield 3794 (early Pleistocene) - Moderately phenocryst-rich lava flows $\left(47.4-47.9 \% \mathrm{SiO}_{2}\right)$ of 2-km-wide lava shield erupted at Hill 3794, centered $2 \mathrm{~km}$ east of Simon Butte. Flows crop out as massive ledges, knobs, and joint blocks covered by thick soil and colluvium. No loose ejecta observed on summit. Phenocrysts: as much as $10 \%$ plag (1-2 mm, plus common shattered plag megacrysts as big as $10 \mathrm{~mm}$ ); rare olivine and cpx (each $\leq 1 \mathrm{~mm}$ ). Overlies units asi, b00, and bsi $(1,875 \pm 3 \mathrm{ka})$. Overlain by units b03, b85, bmf, and bnf $(1,533 \pm 3 \mathrm{ka})$. Undated. [MB]

Basalt of Cone 3963 (early Pleistocene) —Phenocryst-rich lava flows and agglutinate (49.6\% $\mathrm{SiO}_{2}$ ) erupted from compositionally bilateral spatter Cone 3963, $110 \mathrm{~m}$ high, centered $3 \mathrm{~km}$ southeast of McKays Butte. Whereas north and east slopes of cone consist of aphyric trachyte (unit t39), phenocryst-rich unit b39 entirely covers west and south slopes and extends northward as a 500-m-long lava apron. Crops out as massive or vesicular ledges and joint blocks enclosed in thick soil. Phenocrysts: $\sim 20 \%$ plag (seriate $1-10 \mathrm{~mm}$ ) and $1-2 \%$ olivine $(1 \mathrm{~mm})$. Overlies unit bem. Overlain by units $\mathbf{t 3 9}, \mathbf{b 3 6}$, bwf, and bgs $(1,531 \pm 4 \mathrm{ka})$. Undated. [MB]

Trachybasalt of Crag 3541 (Pliocene) — Phenocryst-poor lava flows and ejecta (48.5-48.9\% $\mathrm{SiO}_{2}$ ) erupted at scoria-cone remnant just south of South Fork Yatama Creek. Eroded crags of red scoria and agglutinate mark vent complex $\sim 40 \mathrm{~m}$ high and $350 \mathrm{~m}$ wide capping a 500-m-long ridge of agglutinate knobs and ledges; this grades into an apron of streaky, flowfoliated lava that extends $\sim 1 \mathrm{~km}$ eastward, where its slabby to block-jointed surface supports a rocky meadow. North of Yatama Creek ( $\sim 1 \mathrm{~km}$ from vent), eroded apron continues as a single lava flow that extends discontinuously for $7 \mathrm{~km}$, crossing to north rims of Section Corner and Logy Creeks. Rimrock ledges are massive and slabby or block jointed and range in thickness from $\sim 10 \mathrm{~m}$ to as little as $3 \mathrm{~m}$. Phenocrysts: almost aphyric; contains trace amounts of plagioclase microphenocrysts and even rarer tiny olivine; proximal material locally has sparse plag $(0.5-1 \mathrm{~mm})$ and sparse gabbroic inclusions $(10-30 \mathrm{~mm})$; distally contains rare microphenocrystic clots $(5-10 \mathrm{~mm})$ of cpx+olivine+plag. Overlies units bte $(3,447 \pm 8 \mathrm{ka})$, bys $(3,667 \pm 27 \mathrm{ka})$, mcc, and $\mathbf{m s r}(3,465 \pm 4 \mathrm{ka})$. Overlain by units b14, bta $(3,464 \pm 4 \mathrm{ka})$, bsl $(776 \pm 2 \mathrm{ka})$, and byt $(674 \pm 4 \mathrm{ka})$. Undated. [LCSW, LCF]

Trachybasalt of Cone 3346 (early Pleistocene)—Phenocryst-poor lava flows and ejecta (47.5-48.1\% $\mathrm{SiO}_{2}$ ) erupted at 50-m-high spatter cone $\sim 1 \mathrm{~km}$ wide, $2 \mathrm{~km}$ south of Mike Coon Hillside, midway between White and Tepee Creeks. Cone is capped by dense agglutinate eroded into lumpy ledges. A single narrow lava tongue extends $1 \mathrm{~km}$ south, cropping out as massive knobs, ledges, and joint blocks in loessic soil. Phenocrysts: sparse plag (1-5 mm), 
many elongate; sparse to common olivine $(0.5-1 \mathrm{~mm})$. Overlies units $\mathbf{m t c}, \mathbf{m} 9 \mathbf{3}$, and probably b33. No contiguous units are younger. Undated. [PB]

b47 Basalt of Cone 5147 (early Pleistocene or Pliocene)-Phenocryst-poor lava flow and ejecta $\left(47.7 \% \mathrm{SiO}_{2}\right)$ erupted at small spatter cone $\sim 2 \mathrm{~km}$ south of Smith Butte. Degraded cone, only $500 \mathrm{~m}$ wide with at most $40 \mathrm{~m}$ relief on its steep northeast slope, is capped by stratified agglutinate - moderately welded to tack welded, largely unoxidized, and containing scoria bombs as big as $30 \mathrm{~cm}$. Cone grades out into fountain-fed flows, streaky to massive and block jointed or slabby, that form a narrow tongue extending $1 \mathrm{~km}$ northward. Phenocrysts: none, but products contain sparse microphenocrysts of plag, olivine, and cpx. Overlies units

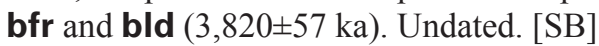

b52

Basalt of Knob 5268 (Pliocene)—Plagioclase-poor, moderately phenocryst-rich lava flows (47.9-48.4\% $\mathrm{SiO}_{2} ; 10-11 \% \mathrm{MgO}$ ) preserved as three remnants near crest of Simcoe Mountains Anticline, $2-3 \mathrm{~km}$ east of Lakebeds. Two small remnants lie on divide at head of Butler Creek; third and largest ( $800 \mathrm{~m}$ wide) lies $150 \mathrm{~m}$ north on steep south wall of Satus Creek. Flows crop out as massive block-jointed ledges and knobs. Knob 5268 has 20-m relief on its downslope face, sheds a barren talus of very coarse joint blocks (many 2-3 m), and may mark site of effusive vent for the unit. Rock is rarely vesicular but locally vuggy and contains streaks and blebs of partially melted rhyolite. Phenocrysts: $2-5 \%$ pyroxene (1-25 $\mathrm{mm}$, rarely $40 \mathrm{~mm}$ ), commonly rimmed by olivine or gray granular reaction rims $1-3 \mathrm{~mm}$ thick; $2-4 \%$ olivine $(1-10 \mathrm{~mm})$, many with spinel inclusions; inhomogeneously distributed, either olivine or pyroxene may predominate locally. Contains rare angular plag fragments as big as $3 \mathrm{~mm}$, rare inclusions of intergrown plag+pyroxene as big as $20 \mathrm{~mm}$, and sparse fine-grained angular inclusions of microgabbro. Largest outcrop also has fragments of dunite and harzburgite as big as $30 \mathrm{~mm}$ that consist of olivine (1-10 mm), opx $(1-30 \mathrm{~mm})$, and sparse cpx $(1-10 \mathrm{~mm})$. Overlies units Tcr and rsc. Undated. [SB] (47.7-49.4\% $\mathrm{SiO}_{2}$ ) of 100-m-high scoria and spatter cone, $1 \mathrm{~km}$ wide, on west rim of Lakebeds. Cone summit rivals Indian Rock (elevation 5,823 ft) as highest spots in Simcoe Mountains. Asymmetrically steep east face of cone reflects Lakebeds Fault Zone. Cone grades out into lava-flow apron that extends at least $5 \mathrm{~km}$ west to Bowman Creek and a similar distance southwest to Mill Creek (south of map area). Cone includes loose scoria and lumpy agglutinate, both mostly oxidized, as well as fountain-fed block-jointed lavas. Apron flows are block jointed, massive, or locally vesicular. Phenocrysts: sparse olivine $(0.5-1 \mathrm{~mm})$, commonly accompanied by abundant olivine microphenocrysts; plag limited to groundmass microlites and rare microphenocrysts. Overlies units Tcr, beb, bld $(3,841 \pm 14 \mathrm{ka})$, and $\mathbf{b p b}(822 \pm 3 \mathrm{ka})$. Younger than all contiguous units mapped, but relations south of map area remain unknown. K-Ar age: $700 \pm 30 \mathrm{ka}$ (K. Uto, written commun., 2008; appendix B). [SB, HB, IR, WPB]

b59 Basalt and trachybasalt of Cone 5659 (Pliocene) - Moderately phenocryst-rich lava flows and ejecta $\left(48.1-51.7 \% \mathrm{SiO}_{2}\right)$ erupted at deeply eroded cone on west rim of Satus Creek canyon just north of Lakebeds. Cone is capped by dense lumpy agglutinate, widely oxidized on surfaces and along joints, locally strewn with scoria lapilli, and intruded by massive plug, which is eroded to a steep, intricately jointed crag $\sim 25 \mathrm{~m}$ high. Roadcut at southeast base of cone (500 $\mathrm{m}$ from crag) exposes stratified oxidized scoria fall at least $6 \mathrm{~m}$ thick, dominantly lapilli but including scoria to $30 \mathrm{~cm}$ and weakly vesicular juvenile bombs as big as $50-80 \mathrm{~cm}$. Lava flows crop out as a belt $1-2 \mathrm{~km}$ wide that extends $4 \mathrm{~km}$ southeast along divide separating Lakebeds from Satus and Butler Creeks. Unit is $\sim 200 \mathrm{~m}$ thick on cliffy amphitheater at head of Satus Creek; massive slabby or block-jointed ledges and rarely exposed vesicular interflow contacts suggest thicknesses of $10-50 \mathrm{~m}$ for individual lava flows. Phenocrysts: $3-15 \%$ plag ( $1-5 \mathrm{~mm}$, rarely $10 \mathrm{~mm}) ; 3-8 \%$ olivine $(0.5-2 \mathrm{~mm})$, commonly in clusters; and subordinate but ubiquitous cpx $(1-5 \mathrm{~mm})$ that ranges from sparse to as much as $3 \%$. Phenocryst proportions range widely, and either olivine or plag can dominate; southerly exposures tend to be richer in olivine, but olivine-dominant and plag-dominant domains appear to be mingled intimately within single flows. Also contains common cpx-plag clots as big as $15 \mathrm{~mm}$ and angular cpx-olivine-plag gabbroic inclusions (5-150 mm). Overlies units Tcr, rsc, bwi, and dni. Overlain by units aec, blw, bcw,

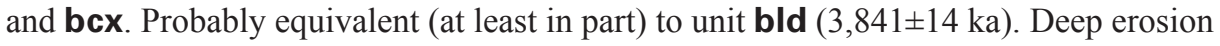


of vent crags and high east-facing scarp on steep headwall of Satus Creek amphitheater suggest possibility of small glacial cirque carved in early or middle Pleistocene; no evidence recognized of late Pleistocene glaciation. Undated. [SB, IR]

b60 Basalt of Cone 3560 (early Pleistocene) - Phenocryst-poor lava flow and ejecta $\left(47.2 \% \mathrm{SiO}_{2}\right)$ of small scoria cone exposed as 1.5-km-long window at south base of McKays Butte. Cone is $\sim 40 \mathrm{~m}$ high, $\sim 500 \mathrm{~m}$ wide, and consists of oxidized scoria blocks, bombs, and lapilli. Lava apron is massive or vesicular, block jointed, and exposed for $700 \mathrm{~m}$ west of cone. Phenocrysts: sparse plag $(1-2 \mathrm{~mm})$ and sparser tiny olivine $(\sim 0.5 \mathrm{~mm})$, plus scattered fragments of plag megacrysts as big as $10 \mathrm{~mm}$. Base not exposed. Overlain by units bcp, bmb $(2,079 \pm 5 \mathrm{ka})$, and bgs $(1,531 \pm 4 \mathrm{ka})$. Undated. [MB]

b62 Trachybasalt of Cone 2862 (early Pleistocene)-Phenocryst-poor lava flow and ejecta (48.2-49.7\% $\mathrm{SiO}_{2}$ ) erupted at 40-m-high spatter cone $\sim 500 \mathrm{~m}$ wide, on north bank of West Fork White Creek. Block-jointed ledges on cone consist of lumpy agglutinate and stubby fountain-fed flows; few loose scoria exposed. Single lava flow incised along shallow bed of West Fork extends $\sim 1 \mathrm{~km}$ south from cone. Phenocrysts: sparse plag $(0.5-2 \mathrm{~mm}$, rarely to $4 \mathrm{~mm}$ ); sparser olivine $(0.5-1 \mathrm{~mm})$. Base not exposed. Overlain by extensive lava aprons of units bsr $(1,685 \pm 11 \mathrm{ka})$ and boh $(981 \pm 14 \mathrm{ka})$. Undated. [PB]

b63 Trachybasalt of Cone 2763 (early Pleistocene)—Scoria cone (47.7-47.9\% $\left.\mathrm{SiO}_{2}\right) \sim 30 \mathrm{~m}$ high, between White and Brush Creeks southeast of Oak Hill Shield. Minor agglutinate on cone but no lava-flow apron is exposed. Scoria and denser cauliflower bombs have $5-8 \%$ plag $(1-3 \mathrm{~mm}$, plus sparse plag megacrysts as big as $10 \mathrm{~mm}$ ) but only sparse small olivine $(<1 \mathrm{~mm})$. Overlies flows of unit bw $(1,885 \pm 5 \mathrm{ka})$. Wrapped by flows of unit bcr $(1,513 \pm 4 \mathrm{ka})$. Undated. [TB]

b65 Trachybasalt of Cone 2865 (Pliocene)—Phenocryst-poor scoria cone $\left(49.2 \% \mathrm{SiO}_{2}\right), \sim 35 \mathrm{~m}$ high, between Hog Swamp and Brush Creek. Cone consists largely of agglutinate and loose oxidized scoria. No lava flows are exposed extending directly outward at base of cone, but a small hackly jointed extrusive flow atop the cone has disintegrated into a pile of massive angular blocks. Nonetheless, cone may cover vent for major lava-flow apron of compositionally similar (not identical) unit bsh. Phenocrysts: sparse olivine and plagioclase (each $\leq 1 \mathrm{~mm}$ ); broken or rounded olivine megacrysts (as big as $6 \mathrm{~mm}$ ); and fragments of plag megacrysts (to $15 \mathrm{~mm}$ ). Clusters of 1-mm olivine are as big as $10 \mathrm{~mm}$. Rare pyroxene occurs intergrown with plag or as free crystals $(1-3 \mathrm{~mm})$ with reaction rims. Apparently overlies and may be related to unit bsh $(3,251 \pm 7 \mathrm{ka})$. Cone is wrapped by younger lavas of units bhs and bnb (1,328 2 ka). Undated. [TB]

b66 Trachybasalt of Cone 2663 (early Pleistocene or Pliocene)—Phenocryst-poor scoria cone $\sim 50 \mathrm{~m}$ high, $1.5 \mathrm{~km}$ south of Twin Buttes on northwest bank of Schafer Creek. Cone consists of sparsely porphyritic, oxidized scoria bombs and lapilli, agglutinate, and stubby spatter-fed flows (47.6-48.1\% $\mathrm{SiO}_{2}$ ). A 25-m-thick lobe of outflow lavas exposed for $350 \mathrm{~m}$ southeastward from the cone is incised by Schafer Creek. Phenocrysts: common small olivine $(0.3-1 \mathrm{~mm})$ and sparse plag $(1-5 \mathrm{~mm})$. Groundmass olivine and plag are commonly conspicuous, especially in weathered rocks. Cone overlies unit bsh $(3,251 \pm 7 \mathrm{ka})$, and lava lobe is overlain by unit bes. Undated. [TB]

b68 Basalt of Shield 2368 (early Pleistocene or Pliocene) - Phenocryst-poor low-K lava flows (48.7-48.9\% $\mathrm{SiO}_{2} ; 0.41-0.65 \% \mathrm{~K}_{2} \mathrm{O}$ ) of small shield, 2-3 km wide with only $50-90 \mathrm{~m}$ total relief, between Bear and Trout Creeks, southeast of Jungle Butte Shield. Except block-jointed flows along gorge rims, exposure is limited to weathered vesicular blocks in thick loessic soil and colluvial rubble. Rocks contain $2-3 \%$ olivine $(\leq 1 \mathrm{~mm}$, some in clusters) and distinctively seriate plagioclase that includes abundant microlites, common microphenocrysts, and 1-3\% euhedral phenocrysts $(1 \mathrm{~mm})$. Overlies units bbe and bpc (3,325 $23 \mathrm{ka})$. Overlain by units $\mathbf{b 2 9}(1,420 \pm 4 \mathrm{ka})$, bdr, bjb $(1,350 \pm 50 \mathrm{ka})$, and bof

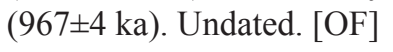

b73, Basalt and trachybasalt of Cone 2873 (early Pleistocene)—Moderately porphyritic agglutinate b73' cone and associated lava-flow apron $\left(49.0-50.6 \% \mathrm{SiO}_{2}\right), 2.5 \mathrm{~km}$ southwest of Poland Butte. Eroded cone is $\sim 50 \mathrm{~m}$ high and consists of dense but lumpy agglutinate that decays into rounded knobs and boulders as big as $3 \mathrm{~m}$. Lava flows crop out as massive to slightly vesicular ledges or as joint blocks in thick soil. About $400 \mathrm{~m}$ southwest of main outcrop, an outlier (subunit b73') $\sim 1 \mathrm{~km}$ long occupies floor of White Creek canyon; lithologically and 
chemically similar, intracanyon remnant contains slightly fewer phenocrysts. Phenocrysts: somewhat varied, ranging between 5 and $10 \%$ total; olivine $(0.5-2 \mathrm{~mm})$ and plag $(1-6 \mathrm{~mm})$ are both common and either may predominate, whereas cpx $(0.5-2 \mathrm{~mm})$ is sparse. Plag includes true phenocrysts and fragments of megacrysts. Rock also locally contains sparse angular fragments as big as $15 \mathrm{~mm}$ of cpx-olivine-feldspar intergrowths. Overlies unit bw $(1,885 \pm 5 \mathrm{ka})$. Overlain by unit bpo $(1,101 \pm 3 \mathrm{ka})$; intracanyon remnant is overlain by unit bcr $(1,513 \pm 4 \mathrm{ka})$. Undated. [TB, PB]

b76 Trachybasalt of Cone 3176 (early Pleistocene)-Phenocryst-poor ejecta $\left(49.7 \% \mathrm{SiO}_{2}\right)$ of 50 -m-high spatter-and-scoria cone, $600 \mathrm{~m}$ wide, $\sim 1 \mathrm{~km}$ southwest of IXL Crossing Road at Tepee Creek. Cone is strewn with cinders and capped by agglutinate that splits into massive joint blocks on summit and grades into hackly, rubbly, thin fountain-fed flows on slopes. Phenocrysts: sparse olivine and plag (both $0.5-1 \mathrm{~mm}$ ) and rare megacrysts of cpx as big as $5 \mathrm{~mm}$. Neither base nor any lava flows are exposed. Overlain by all three contiguous unitsb22, b33, and mtc. Undated. [PB] of fissure-fed eruption of 50-m-high lava cone, $\sim 600 \mathrm{~m}$ wide, $2 \mathrm{~km}$ north of confluence of Tepee and White Creeks. Neither scoria nor conspicuous agglutinate textures were observed. Summit of degraded cone breaks up into massive or slightly vesicular joint blocks, now rounded and 1-4 $\mathrm{m}$ in diameter. Narrow ridge, $\sim 20 \mathrm{~m}$ wide and 6-9 $\mathrm{m}$ high, that extends $300 \mathrm{~m}$ south from cone consists of similar material, unoxidized and massive or only slightly vesicular; likewise breaking up coarsely blocky, its morphology is nonetheless suggestive of fissure-fed homogenized agglutinate rather than an extraordinarily narrow lava flow. Along ridge, a few poorly defined vesicle sheets are deformed. From base of cone, a lava flow also crops out for $\sim 500 \mathrm{~m}$ upstream on east bank of White Creek. Phenocrysts: sparse plag $(1-8 \mathrm{~mm})$ and common but tiny olivine $(\leq 0.5 \mathrm{~mm})$. Base not exposed. Overlain by both contiguous units - blo and b94. Undated. [PB]

Basalt of Crossing 2081 (Pliocene)-Olivine-rich basalt lava flows (49.2-49.6\% $\mathrm{SiO}_{2}$ ) exposed in two areas - one near logging road crossing north fork of Elk Creek (at elevation 2,081), another $2 \mathrm{~km}$ south of there on rim of landslide scarp above Borde Flats. Phenocrysts larger than $0.5 \mathrm{~mm}$ are sparse, but granular groundmass has conspicuous olivine that is seriate from 0.1 to $1 \mathrm{~mm}$. Some of larger olivine crystals occur in clusters. Neither plagioclase nor pyroxene were observed. In both areas, 15- to 20-m-thick sets of olivine-rich flows are intercalated between sets of aphyric flows assigned to unit bpc (3,325 $23 \mathrm{ka})$. Overlain by unit bec. Undated. [OF]

b82 Trachybasalt of Cone 2582 (Pliocene)—Moderately porphyritic agglutinate and lava flows (47.6-48.0\% $\mathrm{SiO}_{2}$ ) erupted at small cone less than $30 \mathrm{~m}$ high, $\sim 1 \mathrm{~km}$ west of confluence of Featherbed and Summit Creeks. Cone ejecta include loose oxidized lapilli and bombs as well as tack-welded, blobby, or dense agglutinate. Lava flows, generally massive and finegrained, crop out for $\sim 1 \mathrm{~km}$ east of cone and discontinuously for $4 \mathrm{~km}$ westward as blockjointed ledges or rounded blocks and slabs in loessic soil. Phenocrysts: $5-10 \%$ plag (mostly $1-4 \mathrm{~mm}$ but a few as big as $8 \mathrm{~mm}$, plus plag megacryst fragments to $12 \mathrm{~mm}$ ); sparse to common olivine (1-2 mm). Overlies flows of units Tcr and bcl (3,298 $\pm 10 \mathrm{ka})$. Overlain by units bcv, bsc $(1,675 \pm 5 \mathrm{ka})$, and bsh $(3,251 \pm 7 \mathrm{ka})$. Undated. [TB, OF]

b84 Trachybasalt of Hill 3484 (Pliocene)-Moderately phenocryst-rich lava flows (47.5-47.7\% $\mathrm{SiO}_{2}$ ) that extend $\sim 5 \mathrm{~km}$ southward along west rim, then floor, of White Creek, north and south of IXL Crossing Road. Source vent concealed to northwest by younger units. Greatest thickness $\sim 85 \mathrm{~m}$ at Hill 3484 near north end of exposures but typically only $\sim 40 \mathrm{~m}$ downstream along gorge of White Creek, where base is not exposed. Crops out as massive ledges, hackly, block jointed, or slabby, rarely vesicular. Phenocrysts: $\sim 10 \%$ plag (1-15 $\mathrm{mm}$ ); sparse olivine and sparser cpx (mostly $\sim 1 \mathrm{~mm}$, both rarely to $3 \mathrm{~mm}$ ). Overlies units buw and bsz (3,323 $\pm 6 \mathrm{ka})$. Overlain by units b01, b94, bix, blo, bsr (1,685 $\pm 11 \mathrm{ka})$, and m93. Undated. [PB]

Trachybasalt of Cone 3985 (early Pleistocene)—Phenocryst-poor lava flows and ejecta (47.3-48.0\% $\mathrm{SiO}_{2}$ ) of 120-m-high scoria cone $\sim 1 \mathrm{~km}$ wide, centered $2.5 \mathrm{~km}$ northeast of Simon Butte. Cinders and scoria bombs of cone are poorly exposed, covered by thick loessic soil. Lava-flow apron, generally massive and block jointed but thickly soil covered, extends $2 \mathrm{~km}$ northwest and $1.5 \mathrm{~km}$ southwest from cone. Phenocrysts: sparse olivine and plag 
(both $\leq 1 \mathrm{~mm}$ ), plus uncommon fragments of shattered plag megacrysts. Overlies units Tcr, b37, bht, bsi (1,875 $\pm 3 \mathrm{ka})$, and asi. Overlain only by unit bnf $(1,533 \pm 3 \mathrm{ka})$, which bisects apron of unit b85. Undated. [MB]

b90 Trachybasalt of Cone 3590 (early Pleistocene) - Moderately phenocryst-rich lava flows and ejecta $\left(47.6-48.0 \% \mathrm{SiO}_{2}\right)$ erupted from 25 -m-high scoria-and-spatter Cone $3590, \sim 5 \mathrm{~km}$ northeast of McKays Butte. Cone is capped by oxidized scoria and joint blocks of streaky to knobbly agglutinate. Low-relief lava aprons extend $1.5 \mathrm{~km}$ north and $1 \mathrm{~km}$ southwest from cone, generally forming subdued surfaces where weathered joint blocks are sparsely exposed through thick soil but support rocky meadows at northwest toe of cone. Phenocrysts: $\sim 5-8 \%$ plag (1-4 mm); 1-2\% olivine ( $\leq 1 \mathrm{~mm})$; and sparse 1-mm cpx. Overlies units bem and bcs $(1,882 \pm 48 \mathrm{ka})$. Overlain by units bwf, bmf, and bnf (1,533 $\pm 3 \mathrm{ka})$. Undated. [MB, CP]

b94 Basalt of Cone 3294 (early Pleistocene)—Phenocryst-poor lava flows and ejecta $\left(48.1 \% \mathrm{SiO}_{2}\right)$ erupted at 50-m-high spatter-and-scoria cone $\sim 500 \mathrm{~m}$ wide, $\sim 1 \mathrm{~km}$ east of White Creek, just south of IXL Crossing Road. Summit of cone strewn with oxidized scoria bombs and rimmed by ledges of streaky dense agglutinate that break slabby or blocky. Lava-flow apron, $1-1.5 \mathrm{~km}$ wide, extends $6 \mathrm{~km}$ south from cone to confluence of Tepee and White Creeks; as thick as $30 \mathrm{~m}$ along both walls of White Creek. Most exposures are massive, mottled, fine-grained, and block-jointed. Phenocrysts: almost aphyric, but contains sparse small olivine ( $0.5-1 \mathrm{~mm}$, rarely $2 \mathrm{~mm}$ ), which is ubiquitous and characteristic of unit; very rare plag (1-2 mm) is typically absent. A single cpx megacryst was seen in hundreds of rocks examined. Overlies units $\mathbf{m t c}$, b80, b84, blo, and bw $(1,885 \pm 5 \mathrm{ka})$. Overlain by units boh ( $981 \pm 14 \mathrm{ka})$, bsr $(1,685 \pm 11 \mathrm{ka})$, and $\mathbf{m 9 3}$. Undated. [PB]

b97 Trachybasalt of Cone 3197 (early Pleistocene)—Phenocryst-poor lava flows (47.5-48.1\% $\mathrm{SiO}_{2}$ ) that extend $1.5 \mathrm{~km}$ southeast and $4 \mathrm{~km}$ southwest from north-trending fissure vent on divide between forks of White and Pole Creeks. Vent alignment $\sim 1 \mathrm{~km}$ long marked by ridge of scoria and agglutinate with $\sim 100$ m relief that culminates in a pair of small hills (3197 and $3150+$ ). Lava flows crop out mostly as massive joint blocks patchily exposed through thick soil or as ledges along rims of stream valleys. Northernmost lobe of unit has apparently been elevated at least $135 \mathrm{~m}$ by steepening of Peavine Ridge Anticline. Phenocrysts: wide range $(1-5 \%)$ in content of plag phenocrysts $(1-4 \mathrm{~mm})$, along with sparse fragments of megacrysts as big as $15 \mathrm{~mm}$; sparse olivine $(\leq 1 \mathrm{~mm})$. Groundmass plag microlites are conspicuous when weathered. Overlies units Tcr and bpc (3,325 $23 \mathrm{ka})$. Overlain by units b10, b29 $(1,420 \pm 4 \mathrm{ka})$, bly $(1,697 \pm 20 \mathrm{ka}), \mathbf{b w k}$, and probably b30. Undated. [SP, PB]

b98 Trachybasalt of Knob 3598 (early Pleistocene or Pliocene)—Moderately phenocryst-rich ejecta $\left(49.7 \% \mathrm{SiO}_{2}\right)$ of small ejecta-cone remnant, $200 \times 100 \mathrm{~m}$ wide and $30 \mathrm{~m}$ high, on lower north wall of Satus Creek gorge, $\sim 1.5 \mathrm{~km}$ west of Telephone Canyon. Northerly dips $\left(10-25^{\circ}\right)$ of stratified ejecta indicate that main body of eroded cone lay above present course of Satus Creek. Lower half of unit consists of massive or crudely stratified ejecta, very coarse and brick red to dark gray; its angular lapilli and blocks (as big as $1 \mathrm{~m}$ ) are poorly vesicular, enclosed in coarse ash matrix. Upper half is well bedded, each layer 1-100 cm thick, containing lapilli and blocks (as big as $30 \mathrm{~cm}$ ) of similar material. Several dikes and irregular sills lace the ejecta. At east end of exposure, a dike-fed flow $(\sim 5 \mathrm{~m}$ thick) of massive to slightly vesicular medium-gray basalt caps the ejecta and dips gently east. Phenocrysts: $\sim 10 \%$ olivine $(0.5-3 \mathrm{~mm}), \sim 5 \%$ plag $(1-2 \mathrm{~mm})$, and sparse cpx $(1-2 \mathrm{~mm})$, as well as rare plag megacrysts as big as $20 \mathrm{~mm}$. Erupted through and overlies unit Tcr. In contact with no other unit. Undated. [LCSW]

dni Trachydacite north of Indian Rock (Pliocene) - Phenocryst-rich lava flow (64.7-67.1\% $\mathrm{SiO}_{2}$; $8.2-8.8 \% \mathrm{Na}_{2} \mathrm{O}+\mathrm{K}_{2} \mathrm{O}$ ) centered $\sim 1 \mathrm{~km}$ north of Indian Rock, capping ridges at head of Butler Creek. Exposure is $\sim 1.3 \mathrm{~km}$ wide at south map boundary and extends at least $500 \mathrm{~m}$ farther south. Outcrops are flow foliated, including both devitrified and glassy layering, and are commonly mottled, vuggy, or oxidized and iron stained. Ridgetop exposure is subdued, mostly weathered joint-blocks in soil and colluvium, but some sidehill spurs are bare and boldly slabby. Phenocrysts: $15 \%$ plag $(1-3 \mathrm{~mm})$ and common cpx. Overlies unit Tcr. Overlain by unit b59. Undated. [SB, IR]

mbr Basaltic trachyandesite of Boundary Road (Pliocene?)-Phenocryst-poor lava flows (51.1$52.0 \% \mathrm{SiO}_{2}$ ) preserved as isolated 600-m-wide ridgecrest remnant atop Simcoe Mountains Anticline, $3 \mathrm{~km}$ east of Lakebeds. Topped by a small knob $\sim 8 \mathrm{~m}$ high, the otherwise gently 
bevelled remnant is $\sim 20 \mathrm{~m}$ thick on its steep northeast face and consists of three flows, each 3-8 $\mathrm{m}$ thick and separated by thin layers of oxidized rubble. Flows are massive and slabby or block jointed. Source vent unknown; no cinders or agglutinate were observed. Phenocrysts: $3-4 \%$ plag $(1-3 \mathrm{~mm})$ and $\sim 1 \%$ olivine $(0.5-2 \mathrm{~mm})$. Rests on unit Tcr. In contact with no other unit. Undated. [SB]

mcc Basaltic andesite of Section Corner Creek (Pliocene)-Phenocryst-rich subalkaline lava flows $\left(54.7-54.9 \% \mathrm{SiO}_{2}\right)$ that emerge from beneath younger units and extend $5 \mathrm{~km}$ northeastward between Yatama and Section Corner Creeks. Supports barren lava benches and rocky meadows, cropping out block jointed to slabby and marked by knobs and ledges. Phenocrysts: abundant plag (1-2 mm); several percent olivine and sparse cpx (both $\leq 1 \mathrm{~mm}$ ). Snowstorm groundmass of plag microlites is commonly conspicuous. Outcrop along Logy Creek, $\sim 1 \mathrm{~km}$ north, is compositionally identical. Base not exposed. All contiguous units are younger. Overlain by units b41, bsl ( $776 \pm 2 \mathrm{ka})$, bxc, byt $(674 \pm 4 \mathrm{ka})$, and $\mathbf{m x c}$. Undated. [LCSW, SB]

mes

mkc

mnb

mns

Basaltic trachyandesite east of Sheep Butte (early Pleistocene)—Phenocryst-poor lava flows and ejecta (51.1-53.0\% $\mathrm{SiO}_{2}$ ) erupted from north-trending fissure vent $\sim 1 \mathrm{~km}$ east of Sheep Butte. Abundant scoria bombs and lapilli and oxidized agglutinate along ridgecrest divide between White Fir and Sheep Creeks; grades outward into aprons of massive or vesicular block-jointed lava flows that extend $700 \mathrm{~m}$ east and $3 \mathrm{~km}$ northwest. Phenocrysts: almost aphyric; contains rare microphenocrysts of olivine and plag; very locally, swarms of fragments of plag megacrysts $(1-4 \mathrm{~mm})$ are accompanied by sparse broken olivine (1-2 mm). May be an early aphyric eruptive phase from same fissure-vent alignment that subsequently produced phenocryst-richer unit bgs. Overlies units bs $(1,722 \pm 5 \mathrm{ka}), \mathbf{b s b}$, and bst. Overlain by units bgs $(1,531 \pm 4 \mathrm{ka})$ and $\mathbf{m w s}$. Undated. [HB]

Basaltic andesite of Kusshi Creek (Pliocene) - Moderately phenocryst-rich lava flows $\left(55.2-55.7 \% \mathrm{SiO}_{2}\right.$ ) that emerge from beneath shield of unit $\mathbf{m s r}$ and extend $\sim 3.5 \mathrm{~km}$ eastward along both sides of North Fork Kusshi Creek. Flows are subalkaline, block jointed, commonly vesicular, and have maximum exposed relief of $\sim 35 \mathrm{~m}$. Phenocrysts: $5-10 \%$ plag (1-3 mm, much of it sieve-textured); $2-3 \%$ olivine ( 1 mm); sparse cpx. Overlies units Tcr, bwc, and rkc. Overlain by units bte $(3,447 \pm 8 \mathrm{ka})$ and $\mathbf{~ m s r}(3,465 \pm 4 \mathrm{ka})$. Undated. [LCSW]

Basaltic trachyandesite north of Blue Creek (early Pleistocene)—Aphyric agglutinate and fountain-fed lava flows $\left(50.3-52.4 \% \mathrm{SiO}_{2}\right.$ ) of large spatter Cone 3432, midway between Sheep and Blue Creeks. Cone is $100 \mathrm{~m}$ high and $1.3 \mathrm{~km}$ long, elongate north-south, and surrounded by lava flows of younger unit bnb. No loose cinders or scoria bombs were observed. Flows and agglutinate are block jointed, massive, or weakly vesicular. Phenocrysts: none, but contains rare fragments $(3-8 \mathrm{~mm})$ of cpx and plag megacrysts. Base not exposed. In contact only with younger phenocryst-rich unit bnb $(1,328 \pm 2 \mathrm{ka})$. Undated. [HB]

Basaltic trachyandesite of North Fork Logy Creek (Pliocene)—Phenocryst-poor lava flows $\left(54.4 \% \mathrm{SiO}_{2}\right)$ that crop out as a 3-km-long swath along canyon of North Fork Logy Creek, east of Smith Butte; a 600-m-long remnant is also preserved along south wall $\sim 2 \mathrm{~km}$ downstream. On canyon walls, flows are exposed as massive ledges, slabby or block jointed. Vent buried by younger units, presumably beneath highland shields to southwest. Phenocrysts: sparse plag $(0.5-2 \mathrm{~mm})$, sparser olivine $(0.5 \mathrm{~mm})$, and cpx rare to absent. Overlies unit bln. Overlain by units bnl, bs (1,722 $\pm 5 \mathrm{ka})$, bsl (776 $\pm 2 \mathrm{ka})$, and $\mathbf{~ m s l}$. Undated. [SB]

Basaltic trachyandesite north of Spring Creek (early Pleistocene)—Phenocryst-poor lava flows $\left(51.3-53.7 \% \mathrm{SiO}_{2}\right)$ that emerge from beneath younger units near upper South Fork Dry Creek and extend $10 \mathrm{~km}$ eastward to rim of main fork above confluence with Spring Creek. Massive flows are block jointed or slabby to platy and 8-15 m thick. Apron of flows is as thick as $25 \mathrm{~m}$ proximally, thinner distally, and not deeply incised medially. Phenocrysts: locally aphyric but generally has $0.1-1 \%$ plag $(1-2 \mathrm{~mm}$, many resorbed or anhedral) and sparse olivine $(0.5-1 \mathrm{~mm})$. Also carries fragments of plag megacrysts as big as $9 \mathrm{~mm}$, olivine-plag clots $(5-10 \mathrm{~mm})$, and rounded quartz crystals with reaction rims, all rare and unevenly distributed. Overlies units Tcr, bds, bfr, bgp, bta (3,464 \pm 4 ka), btw $(4,027 \pm 61$ $\mathrm{ka}$ ), and $\mathbf{m t w}$. Overlain by unit bsd. Undated. [CP, LCF] 
mrw

Basaltic andesite west of Satus Ranger Station (Pliocene)-Moderately phenocrystrich subalkaline lava flows $\left(51.0-54.6 \% \mathrm{SiO}_{2}\right)$ constituting a distinctive rock type that dominates east and southeast surfaces of Castle Rock Shield north of Satus Creek canyon. Olivine-dominant flows crop out at base of shield on north wall of canyon and cover an easterly sector that extends $4 \mathrm{~km}$ northeast to uppermost Yatama Creek. Rocks crop out as massive knobs and ledges, slabby or block jointed, or as weathered rounded blocks, vesicular to massive, enclosed in soil and colluvium. Phenocrysts: abundant olivine (0.5-1 mm), commonly in clusters; plag (1-2 mm) generally subordinate; and sparse but ubiquitous cpx ( 1 mm). Abundant microlites and fewer microphenocrysts of plag are conspicuous in weathered rocks. Locally contains rounded blocks of microgabbro $(50.0 \%$ $\mathrm{SiO}_{2}$; plag $>\mathrm{cpx}>$ olivine), perhaps reservoir-rind fragments erupted with host lava flow. Affinity with overlying unit $\mathbf{m s} \mathbf{l}$ is suggested by mutual content of sparse quartz xenocrysts $(\sim 1 \mathrm{~mm})$ with rusty or pale-green reaction rims. Overlies units Tcr, ayc, rsc, and ret. Overlain by units $\mathbf{~ m s l}(3,550 \pm 4 \mathrm{ka})$, byt $(674 \pm 4 \mathrm{ka})$, and b59. Intruded and overlain by unit msr $(3,465 \pm 4 \mathrm{ka})$. Undated. [SB]

msc

Basaltic andesite of Surveyors Creek (Pliocene)-Phenocryst-poor mafic lava flows (51.2$53.4 \% \mathrm{SiO}_{2}$ ) with conspicuously coarse groundmass that crop out for $4.5 \mathrm{~km}$ along upper Surveyors Creek and its tributaries, just west and southwest of Signal Peak. Exposures are typically massive joint blocks and slabs or, along steep canyon walls, massive ledges separated by vesicular or rubbly scoriaceous zones. Medium-gray rock weathers buff or tan. Thickness of multi-flow package is generally $30-50 \mathrm{~m}$ but locally as thin as $15 \mathrm{~m}$; most individual flows are 3-8 $\mathrm{m}$ thick. Phenocrysts: sparse cpx (1-3 mm; rarely $5 \mathrm{~mm})$; $\sim 1-2 \%$ each of plag and olivine as large as $0.5-1 \mathrm{~mm}$ but abundant microphenocrysts of both - seriate from 0.1 to $0.5 \mathrm{~mm}$. Also contains sparse clusters of olivine or olivine+plag; rare intergrowths of cpx+plag; and sparse fine-grained olivine+plag intergrowths as big as $10 \mathrm{~mm}$. Rests everywhere on unit Tcr. Overlain by units bjs, blp (3,278 $\pm 4 \mathrm{ka})$, and $\mathbf{~ m s k}$ $(3,685 \pm 143 \mathrm{ka})$. Undated. [SP]

msg

Basaltic trachyandesite of South Fork Springs (early Pleistocene or Pliocene) — Phenocrystpoor lava flow $\left(56.6 \% \mathrm{SiO}_{2}\right)$ that crops out as a 600 -m-long window through younger basalts on both walls of canyon of South Fork Dry Creek, near springs at 3,470 ft elevation on canyon floor, $\sim 1 \mathrm{~km}$ south of Dry Creek Road crossing, and $3 \mathrm{~km}$ southeast of Camas Patch. Flow is unique in vicinity, containing abundant tiny olivine $(\leq 0.5 \mathrm{~mm})$ and $2-3 \%$ scattered plag (1-2 mm). Base not exposed. Overlain by units bds, bgp, and bsd. Undated. [CP]

msk Basaltic andesite of Signal Peak (Pliocene)-Large steep shield volcano $\sim 5 \mathrm{~km}$ in diameter, consisting of phenocryst-poor mafic lava flows (52.8-54.6\% $\left.\mathrm{SiO}_{2}\right)$. With $500 \mathrm{~m}$ relief, one of major edifices of Simcoe Mountains volcanic field. Broad flat summit lacks a crater; if one ever existed, it was filled by late effusions. No cinders or agglutinate observed at summit. Thick lava flows crop out poorly as slabs and joint blocks through thick colluvial rubble; distal flows extend $\sim 3.5 \mathrm{~km}$ southeast and southwest of summit. Best exposures are summit nubbins and platy ledges on steep east and north rims of summit flat. Although commonly vesicular on apron, most higher exposures are massive, and all have coarse groundmass of conspicuous plag and lesser olivine; plag-flecked snowstorm groundmass is characteristic. Rocks are dark to medium gray where fresh but typically weather tan. Phenocrysts: abundant plag microphenocrysts $(0.2-0.5 \mathrm{~mm})$ are seriate to sparse phenocrysts as big as $1 \mathrm{~mm}$; olivine ubiquitous but nearly all $\leq 0.5 \mathrm{~mm}$. Overlies units Tcr, buw, bjs, and msc. Overlain by units bsz $(3,323 \pm 6 \mathrm{ka})$, blp $(3,278 \pm 4 \mathrm{ka})$, blo, and bix. ${ }^{40} \mathrm{Ar} /{ }^{39} \mathrm{Ar}$ age: $3,685 \pm 143 \mathrm{ka}$. [SP, PB]

msl Basaltic trachyandesite of South Fork Logy Creek (Pliocene)—Heterogeneous package of evolved lava flows $\left(49-55 \% \mathrm{SiO}_{2}\right)$ of low to moderate phenocryst content that cover much of north and northeast slopes of Castle Rock Shield. Chemically varied set of flows crops out from just northeast of Castle Rock for $\sim 4 \mathrm{~km}$ northeastward to elevation as low as 3,900 $\mathrm{ft}$ in headwaters of Yatama Creek and for $\sim 6 \mathrm{~km}$ northward to $\sim 3,800 \mathrm{ft}$ along Logy Creek. Package of slabby to block-jointed, ledge-forming flows is $>200 \mathrm{~m}$ thick on steep wall of South Fork; commonly erodes into crags, knobs, and rugged rimrock bluffs as well as to weathered rounded boulders in thick loessic soil. Most individual flows 5-25 m thick. Vent presumed to be covered by unit bcx at shield summit. Phenocrysts: $3-15 \%$ plag (mostly $1-5 \mathrm{~mm}$, rarely to $10 \mathrm{~mm}) ; 2-7 \%$ olivine $(0.5-2 \mathrm{~mm})$; and sparse to common cpx $(1-2 \mathrm{~mm})$. 
Some large plag crystals have chalky white rims, and some are rounded. Wide range in olivine/plag proportions such that olivine is locally dominant in some flows or sectors, as in adjacent map unit $\mathbf{m r w}$. Affinity with unit $\mathbf{m r w}$ also suggested by mutual content locally of sparse quartz xenocrysts $(\sim 1 \mathrm{~mm})$ with rusty or pale-green reaction rims. Locally carries sparse, 10-mm, fine-grained, relatively mafic enclaves and sparser silicic inclusions, which are partially melted, finely vesicular, and angular to ovoid or lenticular. Most samples analyzed $(n=30)$ define a high-K compositional array, but a subset of several intercalated flows along South Fork canyon define a medium-K array. Units $\mathbf{m s l}$, mrw, bcw, aec, and bcx were probably all products of the same shield-building system. Overlies units bnl, b59, mnf, mrw, ret, ayc, and probably $\mathbf{m 4 6}$. Overlain by units bcw, bcx, bfr, bsl ( $776 \pm 2 \mathrm{ka})$, byt $(674 \pm 4 \mathrm{ka}) \cdot{ }^{40} \mathrm{Ar} /{ }^{39} \mathrm{Ar}$ age: $3,550 \pm 4 \mathrm{ka}$. [SB]

msp Basaltic trachyandesite of Signal Peak Road (Pliocene)—Aphyric lava flows (53.3-55.4\% $\mathrm{SiO}_{2}$ ) that cap 1-km-wide eastward-sloping plateau that extends $\sim 5 \mathrm{~km}$ along south rim of canyon of South Fork Toppenish Creek. Vent lies north of canyon at Hill 3866, where knobs of dense agglutinate and subordinate red scoria rise above a 1-km-wide, erosionally isolated outlier $\sim 50 \mathrm{~m}$ thick. Flows crop out as ledges and knobs, fine grained and massive, hackly, slabby, or block jointed, and locally flow foliated. Vesicular only locally where zones close to original flow surface are preserved beneath overlying remnant of unit bwd. On plateau surface, blocks exposed through thick soil are mostly punky and weathered tan. Total thickness exposed around plateau margins ranges from $15 \mathrm{~m}$ to $60 \mathrm{~m}$. Phenocrysts: none. Pervasive plag microlites in groundmass help distinguish unit from nearby aphyric units. Composition is unusually sodic for Simcoe region (4.4-5.6\% $\mathrm{Na}_{2} \mathrm{O} ; 7.8-8.7 \%$ total alkalies). Overlies units Tcr, bew, bsz (3,323 $\pm 6 \mathrm{ka})$, bwh, bwr, and bwt. Overlain by unit bwd. ${ }^{40} \mathrm{Ar} /{ }^{39} \mathrm{Ar}$ age: $3,286 \pm 6 \mathrm{ka}$. [PB]

msr Basaltic trachyandesite of Satus Ranger Station (Pliocene)—Phenocryst-poor lava flows (51.6-57.2\% $\mathrm{SiO}_{2}$; mostly $52.2-54.7 \% \mathrm{SiO}_{2}$ ) that form main east slope of Castle Rock Shield. Apron extends $\sim 9 \mathrm{~km}$ northeast to Kusshi Creek and $11 \mathrm{~km}$ eastward where preserved as narrow strip capping steep ridge north of Satus Creek. Source vent is ruggedly eroded plug-like extrusion at Crag 4802 (near site of former Satus Ranger Station) where massive, hackly to block-jointed mass of lava has $30 \mathrm{~m}$ of cliffy relief. Hill 4815 is capped by lava flows, with no evidence for another vent. Lava flows crop out block jointed or slabby to platy, with pale-gray mottles, or as rounded boulders embedded in soil and colluvium. Stack of poorly exposed flows is as thick as $280 \mathrm{~m}$ at Telephone Canyon and thins eastward to $15-50 \mathrm{~m}$ along eastern ridgecrest, where as many as three ledge-forming flows are exposed. Bench-forming outlier as thick as $120 \mathrm{~m}$ is preserved on south wall of Satus Creek canyon, providing evidence of far greater original extent. Phenocrysts: set of many flows ranges from aphyric to crystal poor. Most exposures have traces of olivine $(\leq 0.5 \mathrm{~mm})$ and $\leq 1 \%$ plag $(\leq 1 \mathrm{~mm})$. Rare fragments $(1-6 \mathrm{~mm})$ of shattered plag megacrysts are antecrystic, but sparse rounded 10-mm plag crystals with reaction rims (common in nearvent area) appear to be xenocrysts. Narrow tongue north of Satus Creek grades eastward

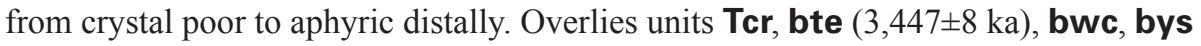
$(3,667 \pm 27 \mathrm{ka}), \mathbf{m k c}, \mathbf{m r w}$, rkc, rsc, and rwc. Overlain by units b41, byt ( $674 \pm 4 \mathrm{ka})$, and probably bkc. ${ }^{40} \mathrm{Ar} /{ }^{39} \mathrm{Ar}$ age: $3,477 \pm 73 \mathrm{ka}$. [SB, LCSW]

mtc Basaltic trachyandesite of Tepee Creek (early Pleistocene)-Aphyric lava flows and ejecta (51.3-53.7\% $\mathrm{SiO}_{2}$ ) erupted at scoria-and-spatter Cone 3240+ midway between White and Tepee Creeks, $\sim 600 \mathrm{~m}$ south of IXL Crossing Road. Summit of cone is dense agglutinate; its flanks are strewn with red cinders and variably oxidized scoria bombs. Lava flows, generally massive and block jointed or slabby, extend $5 \mathrm{~km}$ southward to and along Tepee Creek; greatest thickness exposed is $\sim 40 \mathrm{~m}$. Phenocrysts: none. Overlies units b22, b76, bsi $(1,875 \pm 3 \mathrm{ka})$, btc, and bw $(1,885 \pm 5 \mathrm{ka})$. Overlain by units b33, b46, b94, bpo $(1,101 \pm 3 \mathrm{ka})$, and $\mathbf{m} 93$. Undated. [PB]

mtw Basaltic andesite west of Tannawasha Pasture (Pliocene)—Phenocryst-poor subalkaline lava flows $\left(52.1-53.6 \% \mathrm{SiO}_{2}\right)$ that crop out in a 2-km-long swath along lower north fork of Spring Creek, between Cone 3302 and Dry Creek canyon. Most exposures are massive ledges, block jointed or slabby, locally platy; flow foliation accentuated by deep weathering. On low-relief plateau, crops out as rounded blocks in loessic soil. Only a few exposures retain slightly vesicular surfaces. Phenocrysts: almost aphyric; sparse plag $(0.5-2 \mathrm{~mm})$ is 
commonly exceeded by olivine ( $\sim 1 \mathrm{~mm})$ and cpx $(1-2 \mathrm{~mm}$, rarely $4 \mathrm{~mm})$. Overlies unit Tcr. Overlain by units bds, btw, and $\mathbf{m n s}$. May have been an early eruptive batch from site of Cone 3302; if so, probably little older than overlying porphyritic unit btw $(4,027 \pm 61 \mathrm{ka})$. [LCF]

mvs

mws

$\mathbf{m x c}$

m46

$\mathrm{m} 93$

Trachybasalt and basaltic trachyandesite south of Vessey Springs (early Pleistocene)Phenocryst-poor lava flows and ejecta $\left(48.2-51.4 \% \mathrm{SiO}_{2}\right)$ exposed as a pair of low ridges flanking trachyte Dome 3649 (unit tvs) in a 2-km-wide area just south and west of Vessey Springs. Ridges were built by two northwest-trending fissures that produced scoriaceous and dense ejecta as big as $50 \mathrm{~cm}$, agglutinate, and fountain-fed lava flows, all of which crop out poorly through thick soil and colluvial rubble. Joint blocks are massive or finely vesicular, but nearly all exposures are deeply weathered. Phenocrysts: mostly crystal poor, containing sparse plag and rare olivine (each $\sim 1 \mathrm{~mm}$ ) plus varied cargo of plag megacryst fragments. On both fissure-fed ridges, however, subordinate scoria clasts and agglutinate are moderately phenocryst-rich, carrying as much as $10 \%$ plag $(1-20 \mathrm{~mm}), 1-3 \%$ olivine (mostly $0.5-1.5 \mathrm{~mm}$ but also rare megacrysts as big as $13 \mathrm{~mm}$ ), and sparse cpx (1-10 mm); such crystal-rich scoria also contain sparse clusters of 1-mm olivine (as big as $20 \mathrm{~mm}$ ) as well as sparse intergrowths (also as big as $20 \mathrm{~mm}$ ) of 1-mm plag and olivine. Eastern ridge additionally has ejected blocks of unit Tcr (chemically identified as Grande Ronde Basalt). Overlies units awv and tvs. Overlain by units bcp, bgs (1,531 $\pm 4 \mathrm{ka})$, and bns $(1,566 \pm 3 \mathrm{ka})$. Undated. [HB, MB]

Basaltic trachyandesite west of Smith Butte (early Pleistocene)—Phenocryst-poor lava flows $\left(54.0 \% \mathrm{SiO}_{2}\right)$ capping a 2-km-wide upland surface, just west of Smith Butte and $2 \mathrm{~km}$ north of Stagman Butte, that divides headwaters of White Fir and Sheep Creeks. Vent not identified, presumably covered by unit bnw to south. Poor exposures are mostly rounded vesicular joint blocks protruding from soil and colluvium. Phenocrysts: sparse plag $(1-5 \mathrm{~mm})$ and rare 1-mm olivine. Groundmass is rich in plag microlites and microphenocrysts, accentuated in these generally weathered rocks. Overlies units mes, bhw, bld, bs (1,722 $\pm 5 \mathrm{ka})$, and bst. Overlain by unit bnw. Undated. [SB, HB]

Basaltic trachyandesite of Section Corner Creek (early Pleistocene or Pliocene) Phenocryst-poor lava flows $\left(49.2-54.4 \% \mathrm{SiO}_{2}\right)$ that emerge from beneath younger unit byt as a $2.5-\mathrm{km}$-wide apron that extends $1-3 \mathrm{~km}$ eastward between Yatama and Section Corner Creeks. Outcrops are massive, block jointed, or slabby, rarely vesicular. Vent buried higher on Castle Rock Shield to southwest. Phenocrysts: $1-2 \%$ plag $(1-2 \mathrm{~mm})$ and sparse olivine $(\leq 1 \mathrm{~mm}$ ), plus irregularly distributed plag megacrysts as big as $20 \mathrm{~mm}$. Some variations in plag content may reflect contamination from associated masses of unit bxc. Overlies unit mcc. Overlain by unit byt ( $674 \pm 4 \mathrm{ka})$. Apparently encloses and underlies plag-rich bodies of map unit bxc. Undated. [SB, LCSW]

Basaltic andesite of Hill 4600 (Pliocene)-Phenocryst-rich subalkaline lava flows and agglutinate $\left(54.0 \% \mathrm{SiO}_{2}\right)$ of deeply eroded vent midway between North and South Forks Logy Creek. Cone remnant is 200 x $300 \mathrm{~m}$ across and has $60 \mathrm{~m}$ relief. Outcrops are mostly dense blocks, nubbins, and ledges; locally preserved are sparse loose scoria lapilli and remnants of brick-red, tack-welded agglutinate with rounded blobs $1-15 \mathrm{~cm}$. Phenocrysts: $10-15 \%$ plag $(1-3 \mathrm{~mm}$, rarely $5 \mathrm{~mm}) ; 3-5 \%$ olivine $(0.5-2 \mathrm{~mm})$, commonly in clusters; common cpx (1-2 mm), some clustered with olivine. Contains angular to subrounded inclusions of two kinds: (1) microgabbro with grain size $0.5-2 \mathrm{~mm}$, mostly $1-4 \mathrm{~cm}$ across but as big as $15 \mathrm{~cm}$; (2) fine-grained sugary white felsic clasts, typically $1-3 \mathrm{~cm}$ but as big as $10 \mathrm{~cm}$ - some were slightly melted and retain interstitial glass and others melted extensively and are frothy. Unit is surrounded by lava-flow apron of unit $\mathbf{~ m s l}(3,550 \pm 4 \mathrm{ka})$ and is presumed to predate it. Undated. [SB]

Basaltic trachyandesite and trachyandesite of Hill 3293 (early Pleistocene)—Phenocrystpoor lava flows $\left(52.6-55.6 \% \mathrm{SiO}_{2}\right)$ between Tepee and White Creeks, 2-3 km south of Mike Coon Hillside Anticline. Massive blocks and slabs are rarely vesicular, generally dark to medium gray where fresh, and weather tan to pale gray. Slabby andesite of Hill 3293 shows no evidence for a vent; unit may have issued from beneath site of Cone 3632, which produced younger, more mafic unit b32. Separate aprons extend $3 \mathrm{~km}$ southwest to White Creek and $2 \mathrm{~km}$ southeast to Tepee Creek. Phenocrysts: almost aphyric, but locally carries $\sim 1 \%$ plag $(0.5-2 \mathrm{~mm})$ and trace of olivine microphenocrysts. Overlies units $\mathbf{a} 72$ 
(3,273 $\pm 12 \mathrm{ka})$, blo, b01, b84, b94, and $\mathbf{m t c}$. Overlain by units b32, b33, and b46. Undated. [PB]

rel

Rhyolite east of Lakebeds (Pliocene) - Phenocryst-rich rhyolite lava flow or dome (74.2\% $\mathrm{SiO}_{2}$ ) that forms part of steeply sloping south wall of uppermost Satus Creek gorge $\sim 2 \mathrm{~km}$ east of Lakebeds. Area of exposure is 500 x $800 \mathrm{~m}$. Although no contact is well exposed, $130 \mathrm{~m}$ of steep relief against unit Tcr suggests that unit is in part intrusive. Crops out as ledges and knobs, massive, slabby or block jointed, and pervasively mottled. Phenocrysts: $10-15 \%$ plag (1-2 mm, equant) and sparse oxidized biotite $(\leq 1 \mathrm{~mm})$. Rests on and apparently intrudes unit Tcr. Overlain by phenocryst-poor rhyolitic unit rsc. Undated. [SB]

ret

Rhyolite east of Tadpole Lake (Pliocene)—Phenocryst-poor rhyolite lava (73.2-73.5\% $\mathrm{SiO}_{2}$ ) exposed in three small windows on slopes $0.5-2 \mathrm{~km}$ east of Tadpole Lake. Exposures through steep aprons of younger units are only 150,300, and $400 \mathrm{~m}$ long but are distributed from an elevation as high as $4,550 \mathrm{ft}$ to as low as $3,800 \mathrm{ft}$. Rocks are flow-foliated, commonly convolutely, and range from gray perlite or black glass to pervasively spherulitic or pale-gray and tan felsite; outcrops are locally block jointed or hackly, vuggy, sheared, mottled, or stained by rusty films on fractures. Enclaves and blebs of olivine-plag basalt $(10-30 \mathrm{~mm})$ are common. Phenocrysts: $0-2 \%$ plag $(1-2 \mathrm{~mm})$. Base not exposed. Overlain by units $\mathbf{~ m r w}$, $\mathbf{~ m s l}(3,550 \pm 4 \mathrm{ka})$, and byt (including scoria blanket from Tadpole Lake Cone). May overlie adjacent unit ayc. Undated. [SB]

rkc Rhyolite of Kusshi Creek (Pliocene) —Phenocryst-poor rhyolite lava flows (73.4-73.8\% $\mathrm{SiO}_{2}$ ) preserved as eight remnants along a belt extending $5 \mathrm{~km}$ northeast from upper southwest fork of creek in Wilson Charley Canyon around headwaters forks of Kusshi Creek. Elevation of exposures descends from 4,060 ft in southwest to as low as 3,040 ft in northeast. Source vent buried to west by extensive shield of unit $\mathbf{m s r}$. Rhyolite crops out as knobs, nubbins, ledges, and colluvial rubble; predominantly flow-foliated felsite, pale to medium gray, yellowish tan, or pinkish brown, and commonly vuggy or spherulitic. Rare patches of obsidian and gray pumiceous carapace are preserved locally. Knobs are typically $\sim 5 \mathrm{~m}$ high, but exposure on southwest headwall is $\sim 100$ m thick. Phenocrysts: sparse plag $(\leq 1 \mathrm{~mm})$; commonly aphyric. Overlies unit Tcr. Overlain by units bwc, mkc, and $\mathbf{m s r}(3,465 \pm 4 \mathrm{ka})$. Undated. [LCSW]

rsc Rhyolite of Satus Creek (Pliocene) - Phenocryst-poor rhyolite dome and flows (73.2-74.7\% $\mathrm{SiO}_{2}$ ) widely exposed in upper canyon of Satus Creek. Largest exposure has $360 \mathrm{~m}$ relief and crosses divide from headwaters of Butler Creek to floor of Satus Creek; widely mantled by colluvial slope rubble. Gently dipping glassy margins against unit Tcr are exposed locally, but lower half of high-relief mass is likely to be shallowly intrusive. On north wall of Satus Creek canyon, west of Telephone Canyon, a narrow strip (30-40 m thick) extends $4.5 \mathrm{~km}$ eastward, cropping out in ledges and roadcuts but mostly as felsitic and perlitic colluvial rubble sandwiched by unit Tcr below and mafic lava flows of units $\mathbf{m r w}$ and msr above. In addition, a pair of 100-m-long patches of rhyolitic rubble, consisting of similar felsite and perlite, that crop out along road 0.7-1.3 km southwest of Castle Rock are arbitrarily assigned to this unit, although they enigmatically overlie unit b59. At most outcrops, rock is largely white or cream felsite, locally oxidized orange, flow foliated, and widely spherulitic, vuggy, or brecciated. A few exposures have gray to black contact zones of perlitic glass with rare obsidian kernels. Phenocrysts: rare or as much as 1-2\% plag $(1 \mathrm{~mm})$; mafic crystals absent, altered, or (rarely identifiable) traces of pyroxene $(<1 \mathrm{~mm})$. Overlies units Tcr and rel. Overlain by units b52, b59, bcw, mrw, and $\mathbf{m s r}(3,465 \pm 4 \mathrm{ka})$. Undated. [SB, LCSW]

[Nonwelded rhyolite ignimbrite $>10 \mathrm{~m}$ thick, exposed along Highway 97 just south of map area in Satus Pass quadrangle, $\sim 1 \mathrm{~km}$ north of Satus Pass and 3-4 km south of Satus Creek, may be related to unit rsc; its crystal-poor pumice contains $75.7 \% \mathrm{SiO}_{2}$ and its sparse lithic fragments include perlitic rhyolite lava; no alternative source is recognized other than Satus Creek area. Pumice-rich alluvial deposits along Satus Creek, downstream from Kusshi Creek confluence, may be reworked from this ignimbrite (or from units rsc or rkc). Crystal-poor rhyolite pumice lapilli $\left(5-40 \mathrm{~mm} ; 73-76 \% \mathrm{SiO}_{2}\right.$ ) are abundant in thin-bedded to laminated streamcut exposures as thick as $3 \mathrm{~m}$, dominantly lithic-vitric sand of rhyolite origin, for example, at UTM 6887/51037, Kusshi Creek quadrangle] 
Rhyolite of Tenie Creek (Pliocene) - Scattered remnants of phenocryst-poor rhyolite lava, tuff, and reworked rubble $\left(73.3-76.1 \% \mathrm{SiO}_{2}\right)$ distributed in a narrow belt $3 \mathrm{~km}$ long that extends from headwaters forks of Tenie Creek along its northwest slope as far as road from The Lane to Logy Creek Cow Camp. Source vent not exposed, probably buried to southwest. Small exposure south of Tenie Creek includes a pumice-fall layer with angular, yellow-totan, crystal-poor pumice lapilli $(2-6 \mathrm{~cm})$ and nonwelded ignimbrite, pale to medium gray, moderately indurated, and rich in mafic lithics. Rhyolite clasts in ignimbrite include silky white pumice and transported pieces of flow-banded lava, which are slightly vesicular and include both dense gray felsite and perlitic glass. Along northwest slope of Tenie Creek, a discontinuous series of outcrops of similar tuff and of rhyolite lava remnants extends for about $3 \mathrm{~km}$; lavas are flow foliated, commonly block jointed, and variously felsitic, spherulitic, or glassy. String of outcrops is almost continuously connected by a conspicuous horizon of reworked rhyolitic rubble, much of it baked red orange to brick red by overlying basaltic lava flows. Most remnants appear to be sandwiched between flows of unit bys or between unit bys $(3,667 \pm 27 \mathrm{ka})$ and plateau-capping sheet of unit bte $(3,447 \pm 8 \mathrm{ka})$. Phenocrysts: virtually aphyric; rare plag $(\leq 1 \mathrm{~mm})$ and still rarer tiny pyroxene. Undated. [LCSW]

rwc Rhyolite of Wilson Charley Canyon (Pliocene)—Phenocryst-poor rhyolite $\left(73.6 \% \mathrm{SiO}_{2}\right)$ preserved as 350-m-wide remnant $\sim 1 \mathrm{~km}$ west of confluence of Wilson Charley and Satus Creeks. Its base $\sim 150 \mathrm{~m}$ above confluence, exposure is $\sim 40 \mathrm{~m}$ thick and consists of colluvial rubble and jumble of angular blocks, many as big as $1-3 \mathrm{~m}$. May have originated as slide mass or, more likely, represents talus derived from poorly exposed rhyolite lava. Blocks are flow foliated, largely glassy, with spherulitic and felsitic zones and layers. Phenocrysts: $\sim 3 \%$ plag $(\leq 1 \mathrm{~mm})$. Overlies unit Tcr. Remnant of unit bww apparently banks against it. Overlain by unit $\mathbf{m s r}(3,465 \pm 4 \mathrm{ka})$. Undated. [LCSW]

tvs Trachyte south of Vessey Springs (early Pleistocene or Pliocene)—Aphyric felsite lava dome $\left(63.8-64.2 \% \mathrm{SiO}_{2} ; 11.6-12.0 \% \mathrm{Na}_{2} \mathrm{O}+\mathrm{K}_{2} \mathrm{O}\right), \sim 30 \mathrm{~m}$ high and $600 \mathrm{~m}$ in diameter, cropping out at Hill $3649, \sim 700 \mathrm{~m}$ south of Vessey Springs. Dome is poorly exposed, massive or platy, and deeply weathered; sparse blocks have dark-gray cores enveloped in thick rinds that range from pale gray to yellow orange; locally advanced alteration has produced white rinds and Liesegang rings. Appears to underlie unit mvs. Undated. [HB] $\mathrm{Na}_{2} \mathrm{O}+\mathrm{K}_{2} \mathrm{O}$ ), erupted at compositionally bilateral spatter Cone 3963, $110 \mathrm{~m}$ high, centered 3 $\mathrm{km}$ southeast of McKays Butte. Whereas south and west slopes of cone consist of phenocrystrich olivine-plag basalt (unit b39), this phenocryst-free unit (presumably fountain fed) entirely covers east and north slopes and extends as a 2-km-long lava apron to northeast. Rocks are strongly platy (from summit to terminus), fine grained, pale to medium gray where fresh, but typically weathered punky and tan. Overlies units b39 and bem. Contact with unit b39 passes across true summit of cone. Overlain by unit bwf. Undated. [MB]

\section{References Cited}

Anderson, J.L., 1987a, The structural geology and ages of deformation of a portion of the southwest Columbia Plateau, Washington and Oregon: Los Angeles, University of Southern California, Ph.D. dissertation, 283 p.

Anderson, J.L., 1987b, Geologic map of the Goldendale 15' quadrangle, Washington: Washington Division of Geology and Earth Resources, Open File Report 87-15, scale $1: 38,400$, pamphlet $9 \mathrm{p}$.

Arculus, R.J., 2003, Use and abuse of the terms calcalkaline and calcalkalic: Journal of Petrology, v. 44, p. 929-935.

Bacon, C.R., Bruggman, P.E., Christiansen, R.L., Clynne, M.A., Donnelly-Nolan, J.M., and Hildreth, W., 1997, Primitive magmas at five Cascade volcanic fields-Melts from hot, heterogeneous sub-arc mantle: Canadian Mineralogist, v. 35, p. 397-423.

Barry, T.L., Self, S., Kelley, S.P., Reidel, S., Hooper, P., and Widdowson, M., 2010, New ${ }^{40} \mathrm{Ar} /{ }^{39} \mathrm{Ar}$ dating of the Grande Ronde lavas, Columbia River Basalts, USA-Implications for duration of flood basalt eruption episodes: Lithos, v. 118, p. 213-222.

Bentley, R.D., Anderson, J.L., Campbell, N.P., and Swanson, D.A., 1980, Stratigraphy and structure of the Yakima Indian Reservation, with emphasis on the Columbia River Basalt Group: U.S. Geological Survey Open-File Report 80-200, scale 1:82,529, pamphlet $86 \mathrm{p}$.

Bentley, R.D., Campbell, N.P., and Anderson, J.L., 1988, Geologic map of the Logy Creek 15' quadrangle, Washington: Washington Division of Geology and Earth 
Resources, Geologic Map GM-37.

Bishop, Elizabeth, 1935, The Map, in Winslow, Anne, ed., Trial balances: New York, The Macmillan Company, p.78-79.

Blakely, R.J., Sherrod, B.L., Weaver, C.S., Wells, R.E., Rohay, A.C., Barnett, E.A., and Knepprath, N.E., 2011, Connecting the Yakima fold and thrust belt to active faults in the Puget Lowland, Washington: Journal of Geophysical Research, v. 116, no. B7, B07105.

Boucher, P.R., 1975, Reconnaissance study of sediment transport by selected streams in the Yakima Indian Reservation, Washington: U.S. Geological Survey OpenFile Report 75-67, 11 p.

Calvert, A.T., and Lanphere, M., 2006, Argon geochronology of Kilauea's early submarine history: Journal of Volcanology and Geothermal Research, v. 151, p. 1-18.

Camp. V.E., Ross, M.E., and Hanson, W.E., 2003, Genesis of flood basalts and Basin and Range volcanic rocks from Steens Mountain to the Malheur River gorge, Oregon: Geological Society of America Bulletin, v. 115, p. 105-128.

Campbell, N.P., 1989, Structural and stratigraphic interpretation of rocks under the Yakima fold belt, Columbia Basin, based on recent surface mapping and well data, in Reidel, S.P., and Hooper, P.R., eds., Volcanism and tectonism in the Columbia River flood basalt province: Geological Society of America Special Paper 239, p. 209-222.

Campbell, N.P., and Bentley, R.D., 1981, Late Quaternary deformation of the Toppenish Ridge uplift in south-central Washington: Geology, v. 9, p. 519-524.

Carmichael, I.S.E., 1964, The petrology of Thingmuli, a Tertiary volcano in eastern Iceland: Journal of Petrology, v. 5, p. 435-460.

Catchings, R.D., and Mooney, W.D., 1988, Crustal structure of the Columbia Plateau-Evidence for continental rifting: Journal of Geophysical Research, v. 93, p. 459-474.

Cline, D.R., 1976, Reconnaissance of the water resources of the upper Klickitat River Basin, Yakima Indian Reservation, Washington: U.S. Geological Survey Open-File Report 75-518, $54 \mathrm{p}$.

Clynne, M.A., Calvert, A.T., Wolfe, E.W., Evarts, R.C., Fleck, R.J., and Lanphere, M.A., 2008, The Pleistocene eruptive history of Mount St. Helens, Washington, from 300,000 to 12,800 years before present, in Sherrod, D.R., Scott, W.E., and Stauffer, P.H., eds., A volcano rekindled-The renewed eruption of Mount St. Helens, 2004-2006: U.S. Geological Survey Professional Paper 1750, p. 593-627.

Crosson, R.S., and Owens, T.J., 1987, Slab geometry of the Cascadia subduction zone beneath Washington from earthquake hypocenters and teleseismic converted waves: Geophysical Research Letters, v. 14, p. 824-827.

Evarts, R.C., Conrey, R.M., Fleck, R.J., and Hagstrum, J.T., 2009, The Boring volcanic field of the Portland-Vancouver area, Oregon and Washington-Tectonically anomalous forearc volcanism in an urban setting, in O'Connor, J.E., Dorsey, R.J., and Madin, I.P., eds., Volcanoes to Vineyards - Geologic field trips through the dynamic landscape of the Pacific Northwest: Geological Society of
America Field Guide 15, p. 253-270.

Evarts, R.C., and Swanson, D.A., 1994, Geologic transect across the Tertiary Cascade Range, southern Washington, in Swanson, D.A., and Haugerud, R.A., eds., Geologic field trips in the Pacific Northwest: Department of Geological Sciences, University of Washington, in conjunction with 1994 Annual Meeting of the Geological Society of America, Seattle, v. 2, p. 2H1-2H31.

Fretwell, M.O., 1977, Quality of surface and ground waters, Yakima Indian Reservation, Washington: U.S. Geological Survey Open-File Report 77-128, 215 p.

Gill, J.B., 1981, Orogenic andesites and plate tectonics: Berlin, Springer-Verlag, $390 \mathrm{p}$.

Gradstein, F.M., Ogg, J.G., Smith, A.G., Bleeker, W., and Lourens, L.J., 2004, A new geologic timescale, with special reference to Precambrian and Neogene: Episodes, v. 27, p. $83-100$.

Gregg, D.O., and Laird, L.B., 1975, A general outline of the water resources of the Toppenish Creek Basin, Yakima Indian Reservation, Washington: U.S. Geological Survey Open-File Report 75-19, 37 p.

Gibbard, P.L., Head, M.J., Walker, M.J.C., and the Subcommission on Quaternary Stratigraphy, 2009, Formal ratification of the Quaternary System/Period and the Pleistocene Series/Epoch with a base at 2.58 Ma: Journal of Quaternary Science, ISSN 0267-8179, DOI: 10.1002/ jqs.1338, available at http://www.wiley.com/WileyCDA/.

Halliday, A.N., Fallick, A.E., Dickin, A.P., Mackenzie, A.B., Stephens, W.E., and Hildreth, W., 1983, The isotopic and chemical evolution of Mount St. Helens: Earth and Planetary Science Letters, v. 63, p. 241-256.

Hammond, P.E., and Korosec, M.A., 1983, Geochemical analyses, age dates, and flow-volume estimates for Quaternary volcanic rocks, southern Cascade Mountains, Washington: Washington Division of Geology and Earth Resources Open-File Report 83-13, 36 p., 1 plate.

Hildreth, W., 2007, Quaternary magmatism in the CascadesGeologic perspectives: U.S. Geological Survey Professional Paper 1744, 125 p.

Hildreth, W., and Fierstein, J., 1995, Geologic map of the Mount Adams volcanic field, Cascade Range of southern Washington: U.S. Geological Survey Map I-2460, scale 1:50,000, pamphlet $39 \mathrm{p}$.

Hildreth, W., and Fierstein, J., 1997, Recent eruptions of Mount Adams, Washington Cascades, USA: Bulletin of Volcanology, v. 58, p.472-490.

Hildreth, W., and Lanphere, M.A., 1994, Potassium-argon geochronology of a basalt-andesite-dacite arc system-The Mount Adams volcanic field, Cascade Range of southern Washington: Geological Society of America Bulletin, v. 106, p. 1413-1429.

Hooper, P.R., Camp, V.E., Reidel, S.P., and Ross, M.E., 2007, The origin of the Columbia River flood basalt provincePlume versus nonplume models: Geological Society of America Special Paper 430, p. 635-668.

Indian Claims Commission, 1966, The Yakima Tribe v. the United States: 16 Indian Claims Commission 536, Docket 
No. 47, p. 536-552.

LeBas, M.J., LeMaitre, R.W., Streckeisen, A., and Zanettin, B., 1986, A chemical classification of volcanic rocks based on the total alkali-silica diagram: Journal of Petrology, v. 27, p. $745-750$.

Leeman, W.P., Lewis, J.F., Evarts, R.C., Conrey, R.M., and Streck, M.J., 2005, Petrologic constraints on the thermal structure of the Cascade arc: Journal of Volcanology and Geothermal Research, v. 140, p. 67-105.

Leeman, W.P., Smith, D.R., Hildreth, W., Palacz, Z., and Rogers, N., 1990, Compositional diversity of late Cenozoic basalts in a transect across the southern Washington Cascades-Implications for subduction zone magmatism: Journal of Geophysical Research, v. 95, no. B12, p. 19,561-19,582.

Lipman, P.W., and Mullineaux, D.R., eds., 1981, The 1980 eruptions of Mount St. Helens, Washington: U.S. Geological Survey Professional Paper 1250, 844 p.

McCaffrey, R., Qamar, A.I., King, R.W., Wells, R., Khazaradze, G., Williams, C.A., Stevens, C.W., Vollick, J.J., and Zwick, P.C., 2007, Fault locking, block rotation and crustal deformation in the Pacific Northwest: Geophysical Journal International, v. 169, p. 1315-1340.

McCrory, P.A., Blair, J.L., Oppenheimer, D.H., and Walter, S.R., 2006, Depth to the Juan de Fuca slab beneath the Cascadia subduction margin-A 3-D model sorting earthquakes: U.S. Geological Survey Data Series 91, version 1.2, available on CD-ROM and at http://pubs.usgs.gov/ds/91.

Michaelson, C.A., and Weaver, C.S., 1986, Upper mantle structure from teleseismic P-wave arrivals in Washington and northern Oregon: Journal of Geophysical Research, v. 91, p. 2077-2094.

Mitchell, R.J., Jaeger, D.J., Diehl, J.F., and Hammond, P.E., 1989, Paleomagnetic results from the Indian Heaven volcanic field, south-central Washington: Geophysical Journal, v. 97, p. 381-390.

Miyashiro, A., 1974, Volcanic rock series in island arcs and active continental margins: American Journal of Science, v. 274, p. 321-355.

Molenaar, D., 1977, Outline of the water resources of the Satus Creek Basin, Yakima Indian Reservation, Washington: U.S. Geological Survey Open-File Report 76-808, 34 p.

Mooney, W.D., and Weaver, C.S., 1989, Regional crustal structure and tectonics of the Pacific coastal states, California, Oregon, and Washington: Geological Society of America Memoir 172, p. 129-161.

Muffler, L.J.P., Clynne, M.A., Calvert, A.T., and Champion, D.E., 2011, Diverse, discrete, mantle-derived batches of basalt erupted along a short normal fault zone, the Poison Lake chain, southernmost Cascades: Geological Society of America Bulletin, v. 123, p. 2177-2200.

Mullineaux, D.R., 1996, Pre-1980 tephra-fall deposits erupted from Mount St. Helens, Washington: U.S. Geological Survey Professional Paper 1563, 99 p.

Mullineaux, D.R., and Crandell, D.R., 1981, The eruptive history of Mount St. Helens, in Lipman, P.W., and Mullineaux, D.R., eds., The 1980 eruptions of Mount St.
Helens, Washington: U.S. Geological Survey Professional Paper 1250, p. 3-15.

Mundorff, M.J., MacNish, R.D., and Cline, D.R., 1976, Water resources of the Satus Creek Basin, Yakima Indian Reservation, Washington: U.S. Geological Survey OpenFile Report 76-685, 100 p.

Peacock, M.A., 1931, Classification of igneous rock series: Journal of Geology, v. 39, p. 54-67.

Phillips, W.M., Korosec, M.A., Schasse, H.W., Anderson, J.L., and Hagen, R.A., 1986, K-Ar ages of volcanic rocks in southwest Washington: Isochron West, no. 47, p. 18-24.

Rasmussen, J., and Humphreys, E., 1988, Tomographic image of the Juan de Fuca plate beneath Washington and western Oregon using teleseismic P-wave travel times: Geophysical Research Letters, v. 15, p. 1417-1420.

Reidel, S.P., 1984, The Saddle Mountains - The evolution of an anticline in the Yakima fold belt: American Journal of Science, v. 284, p. 942-978.

Reidel, S.P., Campbell, N.P., Fecht, K.R., and Lindsey, K.A., 1994, Late Cenozoic structure and stratigraphy of southcentral Washington: Washington Division of Geology and Earth Resources Bulletin 80, p. 159-180.

Reidel, S.P., Fecht, K.R., Hagood, M.C., and Tolan, T.L., 1989, The geologic evolution of the central Columbia Plateau, in Reidel, S.P., and Hooper, P.R., eds., Volcanism and tectonism in the Columbia River flood basalt province: Geological Society of America Special Paper 239, p. 247-264.

Reidel, S.P., Martin, B.S., and Petcovic, H.L., 2003, The Columbia River flood basalts and the Yakima fold belt, in Swanson, T.W., ed., Western Cordillera and adjacent areas: Geological Society of America Field Guide 4, p. 87-105.

Scott, W.E., Iverson, R.M., Vallance, J.W., and Hildreth, W., 1995, Volcano hazards in the Mount Adams region, Washington: U.S. Geological Survey Open-File Report 95-492, 11 p., 2 plates.

Sheppard, R.A., 1967a, Geology of the Simcoe Mountains volcanic area, Washington: Washington Division of Geology and Earth Resources, Geologic Map GM-3, scale $1: 125,000$.

Sheppard, R.A., 1967b, Petrology of a late Quaternary potassium-rich andesite flow from Mount Adams, Washington: U.S. Geological Survey Professional Paper 575-C, p. C55-C59.

Sherrod, D.R., Scott, W.E., and Stauffer, P.H., eds., 2008, A volcano rekindled-The renewed eruption of Mount St. Helens, 2004-2006: U.S. Geological Survey Professional Paper 1750, $856 \mathrm{p}$.

Smith, D.R., and Leeman, W.P., 1987, Petrogenesis of Mount St. Helens dacitic magmas: Journal of Geophysical Research, v. 92, p. 10313-10334.

Smith, D.R., and Leeman, W.P., 1993, The origin of Mount St. Helens andesites: Journal of Volcanology and Geothermal Research, v. 55, p. 271-303.

Smith, G.A., 1988, Neogene synvolcanic and syntectonic sedimentation in central Washington: Geological Society of America Bulletin, v. 100, p. 1479-1492. 
Smith, J.G., 1993, Geologic map of upper Eocene to Holocene volcanic and related rocks in the Cascade Range, Washington: U.S. Geological Survey Map I-2005, scale 1:500,000, pamphlet $19 \mathrm{p}$.

Swanson, D.A., Anderson, J.L., Bentley, R.D., Byerly, G.R., Camp, V.E., Gardner, J.N., and Wright, T.L., 1979a, Reconnaissance geologic map of the Columbia River Basalt Group in eastern Washington and northern Idaho: U.S. Geological Survey Open-File Report 79-1363, scale $1: 250,000,24 \mathrm{p}$.

Swanson, D.A., Brown, J.C., Anderson, J.L., Bentley, R.D., Byerly, G.R., Gardner, J.N., and Wright, T.L., 1979c, Preliminary structure contour maps on the top of the Grande Ronde and Wanapum Basalts, eastern Washington and northern Idaho: U.S. Geological Survey Open-File Report 79-1364, scale 1:250,000.

Swanson, D.A., and Clayton, G.A., 1983, Generalized geologic map of the Goat Rocks Wilderness and Roadless Areas (6036, Parts A, C, and D), Lewis and Yakima Counties, Washington: U.S. Geological Survey Open-File Report 83-357, 9 p., scale 1:48,000.

Swanson, D.A., Wright, T.L., Hooper, P.R., and Bentley, R.D., 1979b, Revisions in stratigraphic nomenclature of the Columbia River Basalt Group: U.S. Geological Survey Bulletin 1457-G, 59 p.

Taggart, J.E., Jr., Lindsay, J.R., Scott, B.A., Vivit, D.V., Bartel, A.J., and Stewart, K.C., 1987, Analysis of geologic materials by wavelength-dispersive $\mathrm{x}$-ray fluorescence spectrometry in Baedecker, P.A., ed., Methods for geochemical analysis: U.S. Geological Survey Bulletin 1770, p. E1-E19.

Tolan, T.L., and Reidel, S.P., 1989, Structure map of a portion of the Columbia River flood basalt province, in Reidel, S.P., and Hooper, P.R., eds., Volcanism and tectonism in the Columbia River flood basalt province: Geological Society of America Special Paper 239, scale 1:560,000.

Tolan, T.L., Reidel, S.P., Beeson, M.H., Anderson, J.L., Fecht, K.R., and Swanson, D.A., 1989, Revisions and estimates of the areal extent and volume of the Columbia River
Basalt Group, in Reidel, S.P., and Hooper, P.R., eds., Volcanism and tectonism in the Columbia River flood basalt province: Geological Society of America Special Paper 239, p. 1-20.

U.S. Geological Survey, 1975, Water resources of the Toppenish Creek Basin, Yakima Indian Reservation, Washington: U.S. Geological Survey Water-Resources Investigations 42-144 p.74,

U.S. Supreme Court, 1913, Northern Pacific Railway Company v. United States of America: U.S. Supreme Court, 222 U.S. 355 (1913).

U.S. Supreme Court, 1989, Brendale v. Yakima Nation: U.S. Supreme Court, 492 U.S. 408 (1989).

Uto, K., Hildreth, W., and Lanphere, M.A., 1991, Geology, geochemistry and geochronology of the southern half of the Simcoe Mountains volcanic field, Washington: Eos, Transactions of American Geophysical Union, v. 72, p. 521.

Walsh, T.J., Korosec, M.A., Phillips, W.M., Logan, R.L., and Schasse, H.W., 1987, Geologic map of WashingtonSouthwest quadrant: Washington Division of Geology and Earth Resources, Geologic Map GM-34.

Watters, T.R., 1989, Periodically spaced anticlines of the Columbia Plateau, in Reidel, S.P., and Hooper, P.R., eds., Volcanism and tectonism in the Columbia River flood basalt province: Geological Society of America Special Paper 239, p. 283-292.

Wells, R.E., Weaver, C.S., and Blakely, R.J., 1998, Fore-arc migration in Cascadia and its neotectonic significance: Geology, v. 26, p. 759-762.

West, M.W., Ashland, F.X., Busacca, A.J., Berger, G.W., and Shaffer, M.E., 1996, Late Quaternary deformation, Saddle Mountains Anticline, south-central Washington: Geology, v. 24, p. 1123-1126.

Zoback, M.D., and Zoback, M.L., 1991, Tectonic stress field of North America and relative plate motions, in Slemmons, D.B., Engdahl, E.R., Zoback, M.D., and Blackwell, D.D., eds., Neotectonics of North America: Geological Society of America, Decade Map Volume 1, p. 339-366. 
Table 1. ${ }^{40} \mathrm{Ar} /{ }^{39} \mathrm{Ar}$ ages for basalt samples from Simcoe Mountains volcanic field.

[Samples irradiated at U.S. Geological Survey TRIGA reactor using 9.6345 Ma Bodie Hills sanidine as a neutron flux monitor. Abbreviations: MSWD, mean square weighted deviation; Quad, quadrangle name as explained in introduction to Description of Map Units. Preferred ages in bold font. All samples were hand-picked concentrates of dense crystalline groundmass. For details of methods, see Muffler and others (2011)]

\begin{tabular}{|c|c|c|c|c|c|c|c|}
\hline \multirow{2}{*}{ Sample No. } & \multirow{2}{*}{ Unit label } & \multirow{2}{*}{ Quad } & \multirow{2}{*}{$\begin{array}{l}\text { UTM grid } \\
\text { (E/N) }\end{array}$} & \multicolumn{3}{|c|}{${ }^{40} \mathrm{Ar} /{ }^{39} \mathrm{Ar}$ weighted mean plateau age } & \multirow{2}{*}{$\begin{array}{l}\text { Recoil model } \\
\text { age (ka) }\end{array}$} \\
\hline & & & & Age (ka) & $\%^{39} \mathrm{Ar}$ [steps, $\left.{ }^{\circ} \mathrm{C}\right]$ & MSWD & \\
\hline SM-92 & blp & $\mathrm{CF}$ & $425 / 251$ & $3276.9 \pm 8.6$ & $80[575-800]$ & 5.56 & $3277.9 \pm 8.6$ \\
\hline SM-97 & bsc & TB & $523 / 999$ & $1674.5 \pm 4.8$ & $60[600-790]$ & 0.32 & \\
\hline SM-102 & $\mathrm{bpb}$ & $\mathrm{HB}$ & $641 / 976$ & $822.1 \pm 2.9$ & $63[600-750]$ & 1.23 & \\
\hline SM-103 & bbl & TB & $528 / 051$ & $1686.5 \pm 4.6$ & $72[600-740]$ & 1.00 & \\
\hline SM-205 & $\mathrm{msr}$ & LCSW & $776 / 038$ & $3464.6 \pm 11.3$ & $53[655-775]$ & 1.90 & $3477.3 \pm 72.5$ \\
\hline SM-241 & bfc & $\mathrm{TB}$ & $541 / 981$ & $680.7 \pm 1.8$ & $67[650-850]$ & 1.19 & \\
\hline SM-271 & bnb & $\mathrm{HB}$ & $559 / 060$ & $1327.6 \pm 2.0$ & $78[550-850]$ & 0.26 & \\
\hline SM-298 & bhb & $\mathrm{HB}$ & $553 / 018$ & $1275.6 \pm 4.8$ & $64[600-750]$ & 1.48 & \\
\hline SM-304 & bmb & MB & $587 / 115$ & $2079.3 \pm 6.4$ & $79[600-740]$ & 1.50 & \\
\hline SM-320 & bw & TB & $491 / 072$ & $1884.6 \pm 5.4$ & $61[600-750]$ & 0.18 & \\
\hline SM-345 & bsm & $\mathrm{HB}$ & $641 / 022$ & -- & $67[550-750]$ & 15.14 & $2056.0 \pm 24.5$ \\
\hline SM-348 & bld & SB & $652 / 020$ & -- & $88[650-1100]$ & 42.92 & $3820.2 \pm 57.2$ \\
\hline SM-351 & bs & SB & $647 / 076$ & $1721.9 \pm 4.9$ & $65[600-800]$ & 0.69 & \\
\hline SM-370 & bsp & TB & $458 / 999$ & $3280.0 \pm 7.5$ & $78[550-800]$ & 0.47 & \\
\hline SM-372 & btb & ТВ & $471 / 009$ & $3262.3 \pm 4.6$ & $100[550-1100]$ & 0.50 & \\
\hline SM-400 & boc & MB & $591 / 210$ & $2136.1 \pm 5.5$ & $86[600-825]$ & 1.05 & \\
\hline SM-408 & bsi & MB & $578 / 180$ & $1875.1 \pm 2.8$ & $74[650-950]$ & 1.58 & \\
\hline SM-417 & bcr & MB & $546 / 159$ & $1513.4 \pm 3.5$ & $100[550-1100]$ & 1.59 & \\
\hline SM-430 & bgs & MB & $603 / 109$ & $1530.6 \pm 4.9$ & $75[600-850]$ & 1.32 & \\
\hline SM-440 & bnf & $\mathrm{CP}$ & $670 / 157$ & $1532.9 \pm 2.8$ & $52[750-900]$ & 0.20 & \\
\hline SM-488 & $\mathrm{msl}$ & SB & $698 / 053$ & $3549.6 \pm 4.4$ & $38[785-925]$ & 1.75 & $3614.4 \pm 74.3$ \\
\hline SM-494 & bsl & SB & $729 / 079$ & $776.3 \pm 1.3$ & $82[650-975]$ & 0.48 & \\
\hline SM-496 & bs & SB & $736 / 093$ & $1721.6 \pm 4.6$ & $67[550-750]$ & 0.28 & \\
\hline SM-499 & bld & SB & $657 / 976$ & $3839.9 \pm 14.3$ & $92[550-950]$ & 12.21 & $3841.0 \pm 14.3$ \\
\hline SM-529 & bsn & $\mathrm{CP}$ & $654 / 116$ & $1479.2 \pm 3.4$ & $45[900-1200]$ & 1.62 & \\
\hline SM-530 & bsf & $\mathrm{CP}$ & $689 / 206$ & -- & $100[550-1150]$ & 19.54 & $2060.4 \pm 10.1$ \\
\hline SM-564 & bcs & $\mathrm{CP}$ & $663 / 142$ & $1608.8 \pm 2.3$ & 73[700-950] & 0.74 & \\
\hline SM-573 & bte & LCSW & $812 / 054$ & $3446.8 \pm 9.9$ & $86[550-775]$ & 1.45 & \\
\hline SM-616 & bys & LCSW & $813 / 100$ & -- & $82[600-975]$ & 36.79 & $3708.2 \pm 36.9$ \\
\hline SM-617 & byt & LCSW & $811 / 099$ & $674.4 \pm 3.6$ & $89[550-1050]$ & 1.35 & \\
\hline SM-689 & btw & $\mathrm{LCF}$ & $752 / 116$ & -- & $99[600-1250]$ & 72.35 & $4027.3 \pm 60.9$ \\
\hline SM-695 & bof & ТВ & $455 / 003$ & $967.2 \pm 4.3$ & $100[550-1100]$ & 1.29 & \\
\hline SM-705 & bpo & $\mathrm{PB}$ & $511 / 102$ & $1101.3 \pm 3.3$ & $60[700-925]$ & 2.40 & \\
\hline SM-711 & boh & ТВ & $470 / 060$ & $981.1 \pm 14.1$ & $47[675-850]$ & 1.94 & $968.2 \pm 34.4$ \\
\hline SM-726 & bkl & ТВ & $450 / 033$ & $1748.3 \pm 5.4$ & $70[650-850]$ & 2.43 & \\
\hline SM-741 & bns & TB & $540 / 077$ & $1565.8 \pm 3.4$ & $59[700-875]$ & 0.23 & \\
\hline
\end{tabular}




\begin{tabular}{|c|c|c|c|c|c|}
\hline \multicolumn{4}{|c|}{${ }^{40} \mathrm{Ar} /{ }^{39} \mathrm{Ar}$ isotope correlation (isochron) age } & \multirow{2}{*}{$\begin{array}{c}{ }^{40} \mathrm{Ar} /{ }^{39} \mathrm{Ar} \text { total-gas } \\
\text { age (ka) }\end{array}$} & \multirow{2}{*}{ Preference } \\
\hline Age (ka) & $\%^{39} \mathrm{Ar}$ [steps, $\left.{ }^{\circ} \mathrm{C}\right]$ & MSWD & ${ }^{40} \mathrm{Ar} /{ }^{36} \mathrm{Ar}_{\mathrm{i}}$ & & \\
\hline $3280.6 \pm 8.1$ & $80[575-800]$ & 5.18 & $281.4 \pm 39.4$ & $3245.4 \pm 3.6$ & Recoil model age \\
\hline $1684.0 \pm 20.3$ & $60[600-790]$ & 0.40 & $289.4 \pm 28.7$ & $1673.9 \pm 4.4$ & Plateau age \\
\hline $813.1 \pm 10.7$ & $63[600-750]$ & 1.43 & $306.8 \pm 29.3$ & $806.9 \pm 2.5$ & Plateau age \\
\hline $1681.1 \pm 21.3$ & $72[600-740]$ & 1.50 & $299.6 \pm 37.1$ & $1669.5 \pm 4.4$ & Plateau age \\
\hline $3512.9 \pm 17.9$ & $53[655-775]$ & 0.25 & $193.7 \pm 71.8$ & $3455.3 \pm 7.6$ & Recoil model age \\
\hline $684.4 \pm 4.4$ & $67[650-850]$ & 1.26 & $292.1 \pm 8.4$ & $665.0 \pm 1.7$ & Plateau age \\
\hline $1325.8 \pm 4.6$ & $78[550-850]$ & 0.28 & $297.7 \pm 11.2$ & $1325.0 \pm 2.4$ & Plateau age \\
\hline $1273.2 \pm 20.6$ & $64[600-750]$ & 2.43 & $297.8 \pm 48.0$ & $1276.0 \pm 4.0$ & Plateau age \\
\hline $2082.5 \pm 9.6$ & $79[600-740]$ & 1.88 & $285.3 \pm 47.8$ & $2058.1 \pm 5.1$ & Plateau age \\
\hline $1882.1 \pm 22.0$ & $61[600-750]$ & 0.29 & $298.1 \pm 51.2$ & $1876.4 \pm 5.2$ & Plateau age \\
\hline $2131.1 \pm 26.5$ & $67[550-750]$ & 3.48 & $209.6 \pm 55.2$ & $1890.4 \pm 7.0$ & Recoil model age \\
\hline $3833.9 \pm 25.5$ & $88[650-1100]$ & 22.58 & $248.6 \pm 27.6$ & $3777.7 \pm 8.5$ & Recoil model age \\
\hline $1735.6 \pm 16.5$ & $65[600-800]$ & 0.78 & $284.6 \pm 28.2$ & $1718.9 \pm 4.7$ & Plateau age \\
\hline $3276.1 \pm 13.1$ & $78[550-800]$ & 0.55 & $299.3 \pm 23.9$ & $3267.9 \pm 7.3$ & Plateau age \\
\hline $3260.7 \pm 12.3$ & $100[550-1100]$ & 0.66 & $296.4 \pm 16.5$ & $3249.6 \pm 4.5$ & Plateau age \\
\hline $2138.1 \pm 9.2$ & $86[600-825]$ & 1.35 & $292.9 \pm 20.0$ & $2136.1 \pm 5.5$ & Plateau age \\
\hline $1870.0 \pm 7.5$ & $74[650-950]$ & 1.74 & $301.7 \pm 20.5$ & $1864.3 \pm 2.3$ & Plateau age \\
\hline $1523.9 \pm 17.1$ & $100[550-1100]$ & 1.72 & $289.6 \pm 21.4$ & $1512.9 \pm 2.8$ & Plateau age \\
\hline $1535.7 \pm 10.7$ & $75[600-850]$ & 1.80 & $292.3 \pm 13.6$ & $1518.4 \pm 4.1$ & Plateau age \\
\hline $1529.6 \pm 21.5$ & $52[750-900]$ & 0.28 & $299.4 \pm 56.9$ & $1533.9 \pm 2.6$ & Plateau age \\
\hline $3567.9 \pm 7.1$ & $38[785-925]$ & 0.17 & $274.6 \pm 15.4$ & $3614.6 \pm 3.2$ & Plateau age \\
\hline $774.6 \pm 3.9$ & $82[650-975]$ & 0.53 & $298.5 \pm 15.4$ & $770.4 \pm 1.4$ & Plateau age \\
\hline $1705.6 \pm 27.3$ & $67[550-750]$ & 0.27 & $319.1 \pm 94.9$ & $1710.2 \pm 4.4$ & Plateau age \\
\hline $3834.8 \pm 18.9$ & $92[550-950]$ & 16.17 & $297.4 \pm 78.6$ & $3823.5 \pm 4.2$ & Recoil model age \\
\hline $1472.2 \pm 16.5$ & $45[900-1200]$ & 1.87 & $297.4 \pm 10.0$ & $1364.9 \pm 2.2$ & Plateau age \\
\hline $2060.8 \pm 9.7$ & $100[550-1150]$ & 21.77 & $292.4 \pm 33.9$ & $2061.0 \pm 2.3$ & Recoil model age \\
\hline $1619.3 \pm 8.3$ & $73[700-950]$ & 0.53 & $285.6 \pm 16.9$ & $1594.3 \pm 2.3$ & Plateau age \\
\hline $3446.9 \pm 15.1$ & $86[550-775]$ & 1.84 & $295.0 \pm 51.8$ & $3488.2 \pm 31.2$ & Plateau age \\
\hline $3769.1 \pm 50.3$ & $82[600-975]$ & 29.16 & $272.9 \pm 26.7$ & $3659.1 \pm 9.4$ & Recoil model age \\
\hline $699.9 \pm 20.9$ & $89[550-1050]$ & 1.26 & $286.5 \pm 15.8$ & $668.2 \pm 3.1$ & Plateau age \\
\hline $4160.3 \pm 76.6$ & $99[600-1250]$ & 45.74 & $260.6 \pm 26.1$ & $3941.2 \pm 7.5$ & Recoil model age \\
\hline $984.7 \pm 7.4$ & $100[550-1100]$ & 0.56 & $290.3 \pm 4.5$ & $962.5 \pm 4.0$ & Plateau age \\
\hline $1109.9 \pm 9.1$ & $60[700-925]$ & 2.42 & $286.2 \pm 21.0$ & $1084.9 \pm 1.9$ & Plateau age \\
\hline $926.256 \pm 92.7$ & $47[675-850]$ & 2.30 & $296.8 \pm 4.8$ & $1009.0 \pm 7.2$ & Plateau age \\
\hline $1745.0 \pm 8.4$ & $70[650-850]$ & 3.03 & $297.4 \pm 9.9$ & $1729.4 \pm 3.6$ & Plateau age \\
\hline $1564.0 \pm 5.7$ & $59[700-875]$ & 0.25 & $297.3 \pm 10.1$ & $1552.6 \pm 3.5$ & Plateau age \\
\hline
\end{tabular}


Table 1. ${ }^{40} \mathrm{Ar} /{ }^{39} \mathrm{Ar}$ ages for basalt samples from Simcoe Mountains volcanic field—Continued.

\begin{tabular}{|c|c|c|c|c|c|c|c|}
\hline \multirow{2}{*}{ Sample No. } & \multirow{2}{*}{ Unit label } & \multirow{2}{*}{ Quad } & \multirow{2}{*}{$\begin{array}{l}\text { UTM grid } \\
\text { (E/N) }\end{array}$} & \multicolumn{3}{|c|}{${ }^{40} \mathrm{Ar} /{ }^{39} \mathrm{Ar}$ weighted mean plateau age } & \multirow{2}{*}{$\begin{array}{l}\text { Recoil model } \\
\text { age (ka) }\end{array}$} \\
\hline & & & & Age (ka) & $\%{ }^{39} \mathrm{Ar}\left[\right.$ steps, $\left.{ }^{\circ} \mathrm{C}\right]$ & MSWD & \\
\hline SM-788 & bta & $\mathrm{LCF}$ & $823 / 121$ & $3464.2 \pm 3.0$ & $50[800-950]$ & 0.15 & \\
\hline SM-833 & bsr & PB & $461 / 115$ & $1684.9 \pm 11.1$ & $73[650-800]$ & 9.95 & $1684.1 \pm 11.2$ \\
\hline SM-850 & a72 & PB & $522 / 175$ & $3273.1 \pm 11.8$ & $60[700-860]$ & 3.15 & $3279.4 \pm 28.5$ \\
\hline SM-912 & bly & PB & $458 / 151$ & $1703.2 \pm 11.7$ & $71[650-900]$ & 8.26 & $1696.8 \pm 19.5$ \\
\hline SM-1014 & bsz & PB & $473 / 215$ & $3322.6 \pm 5.9$ & $81[650-950]$ & 1.88 & \\
\hline SM-1039 & bsh & $\mathrm{OF}$ & $445 / 972$ & $3250.9 \pm 7.3$ & $69[650-900]$ & 1.37 & \\
\hline SM-1063 & b29 & $\mathrm{OF}$ & $403 / 075$ & $1420.0 \pm 3.5$ & $88[550-850]$ & 1.20 & \\
\hline SM-1065 & bpc & SP & $388 / 121$ & $3335.9 \pm 11.7$ & $52[690-850]$ & 2.77 & $3324.5 \pm 23.0$ \\
\hline SM-1075 & bcl & DC & $449 / 953$ & $3298.1 \pm 9.6$ & $74[650-930]$ & 1.95 & \\
\hline SM-1079 & bkl & $\mathrm{OF}$ & $421 / 019$ & $1739.7 \pm 2.3$ & $84[600-900]$ & 0.42 & \\
\hline SM-1289 & bpt & $\mathrm{CF}$ & $415 / 281$ & -- & $100[550-1100]$ & 54.41 & $3568.4 \pm 55.3$ \\
\hline SM-1293 & msk & SP & $439 / 207$ & -- & $100[550-1100]$ & 366.86 & $3684.5 \pm 143.1$ \\
\hline SM-1295 & $\mathrm{msp}$ & PB & $482 / 100$ & $3285.6 \pm 6.4$ & $54[680-850]$ & 0.20 & \\
\hline
\end{tabular}




\begin{tabular}{|c|c|c|c|c|c|}
\hline \multicolumn{4}{|c|}{${ }^{40} \mathrm{Ar} /{ }^{39} \mathrm{Ar}$ isotope correlation (isochron) age } & \multirow{2}{*}{$\begin{array}{c}{ }^{40} \mathrm{Ar} /{ }^{39} \mathrm{Ar} \text { total-gas } \\
\text { age (ka) }\end{array}$} & \multirow{2}{*}{ Preference } \\
\hline Age (ka) & $\%^{39} \mathrm{Ar}\left[\right.$ steps, $\left.^{\circ} \mathrm{C}\right]$ & MSWD & ${ }^{40} \mathrm{Ar} /{ }^{36} \mathrm{Ar}_{\mathrm{i}}$ & & \\
\hline $3463.3 \pm 4.9$ & $50[800-950]$ & 0.21 & $296.2 \pm 7.4$ & $3447.0 \pm 2.8$ & Plateau age \\
\hline $1672.735 \pm 8.1$ & $73[650-800]$ & 5.48 & $324.2 \pm 38.4$ & $1673.5 \pm 3.6$ & Plateau age \\
\hline $3270.6 \pm 11.0$ & $60[700-860]$ & 3.55 & $304.2 \pm 71.3$ & $3278.7 \pm 6.6$ & Plateau age \\
\hline $1696.2 \pm 23.6$ & $71[650-900]$ & 9.95 & $299.3 \pm 32.5$ & $1677.2 \pm 4.1$ & Recoil model age \\
\hline $3315.6 \pm 10.3$ & $81[650-950]$ & 1.99 & $299.9 \pm 13.5$ & $3318.7 \pm 4.3$ & Plateau age \\
\hline $3245.0 \pm 35.0$ & $69[650-900]$ & 1.70 & $296.2 \pm 9.1$ & $3252.3 \pm 6.1$ & Plateau age \\
\hline $1419.8 \pm 5.9$ & $88[550-850]$ & 1.42 & $295.6 \pm 12.2$ & $1410.5 \pm 3.2$ & Plateau age \\
\hline $3322.3 \pm 21.8$ & $52[690-850]$ & 3.24 & $304.7 \pm 31.9$ & $3319.8 \pm 6.9$ & Recoil model age \\
\hline $3308.4 \pm 21.0$ & $74[650-930]$ & 2.16 & $287.6 \pm 32.8$ & $3283.6 \pm 6.9$ & Plateau age \\
\hline $1737.2 \pm 7.6$ & $84[600-900]$ & 0.48 & $296.9 \pm 9.8$ & $1737.4 \pm 2.3$ & Plateau age \\
\hline $3567.1 \pm 70.0$ & $100[550-1100]$ & 50.30 & $293.0 \pm 53.1$ & $3566.1 \pm 12.1$ & Recoil model age \\
\hline $3492.8 \pm 114.9$ & $100[550-1100]$ & 217.51 & $394.2 \pm 184.6$ & $3688.7 \pm 7.5$ & Recoil model age \\
\hline $3285.6 \pm 7.2$ & $54[680-850]$ & 0.26 & $295.1 \pm 24.9$ & $3271.8 \pm 6.3$ & Plateau age \\
\hline
\end{tabular}


Appendix B. Whole-rock potassium-argon ages for units within or overlapping Simcoe Mountains volcanic field, main central segment.

[Analyses by K. Uto at U.S. Geological Survey in Menlo Park (then supervised by M.A. Lanphere) or at Geological Survey of Japan (GSJ) in Tsukuba, in collaboration with Hildreth and Fierstein]

\begin{tabular}{|c|c|c|c|c|c|c|c|}
\hline Sample No. & $\begin{array}{l}\text { Unit label or } \\
\text { description }\end{array}$ & $\begin{array}{l}\text { UTM grid } \\
\text { (E/N) }\end{array}$ & $\% \mathrm{SiO}_{2}$ & Age (ka) & $\mathbf{w t} \% \mathrm{~K}_{2} \mathbf{0}$ & $\begin{array}{l}\text { Radiogenic } \\
\operatorname{Ar}(\%)\end{array}$ & Lab number \\
\hline \multicolumn{8}{|c|}{ Menlo Park } \\
\hline SIM91273 & bps & $592 / 956$ & 50.3 & $631 \pm 27$ & 2.105 & 15.91 & $91 \mathrm{I} 397$ \\
\hline SIM91289 & bkb & $565 / 955$ & 48.98 & $688 \pm 25$ & 1.833 & 17.72 & $91 \mathrm{I} 386$ \\
\hline SIM90059 & bwi & $689 / 954$ & 50.6 & $3,990 \pm 40$ & 1.298 & 55.4 & $91 \mathrm{I} 089$ \\
\hline SIM90060 & $\begin{array}{l}\text { Top lava flow of shield; } \\
50 \mathrm{~m} \text { S. of basaltic } \\
\text { plug called Indian } \\
\text { Rock }\end{array}$ & $689 / 949$ & 47.33 & $3,980 \pm 40$ & 1.323 & 69.13 & $91 \mathrm{I} 095$ \\
\hline SIM90061 & $\begin{array}{l}\text { Rhyolite; } 300 \mathrm{~m} \mathrm{~S} \text {. of } \\
\text { Indian Rock }\end{array}$ & $689 / 947$ & 74.18 & $3,720 \pm 60$ & 4.88 & 40.91 & $91 \mathrm{I} 387$ \\
\hline SIM90215 & $\begin{array}{l}\text { Shield-top vent; Knoll } \\
5451 ; 1.5 \mathrm{~km} \text { ENE. } \\
\text { of Indian Rock }\end{array}$ & $701 / 957$ & 49.75 & $4,030 \pm 40$ & 1.239 & 45.29 & $91 \mathrm{I} 075$ \\
\hline SM-564 & bcs & $663 / 142$ & 48.7 & $1882 \pm 48$ & 1.34 & 48.2 & - \\
\hline \multicolumn{8}{|c|}{ GSJ-Tsukuba } \\
\hline SIM91376 & b58 & $666 / 958$ & 49.3 & $700 \pm 30$ & 1.801 & 19 & 2308 \\
\hline \multirow[t]{2}{*}{ MA-972 } & bjb & $339 / 085$ & 51.9 & $\begin{array}{l}1,350 \pm 60 \\
1360 \pm 70\end{array}$ & 1.12 & $\begin{array}{c}12 . \\
104\end{array}$ & $\begin{array}{l}2311 \\
2312\end{array}$ \\
\hline & & & & avg. $=1,350 \pm 50$ & & & \\
\hline \multirow[t]{2}{*}{ MA-752 } & bwb & $351 / 939$ & 52.2 & $\begin{array}{l}3,480 \pm 100 \\
3,400 \pm 100\end{array}$ & 0.95 & $\begin{array}{l}18.2 \\
18.3\end{array}$ & $\begin{array}{l}2331 \\
2333\end{array}$ \\
\hline & & & & avg. $=3,440 \pm 70$ & & & \\
\hline
\end{tabular}

